NIST GCR 21-027

\title{
Survey of Federal Community Resilience Programs and Available Resilience Planning Tools
}

Thomas Olszewski

Irina Liu

Allison Cunningham

This publication is available free of charge from: https://doi.org/10.6028/NIST.GCR.21-027

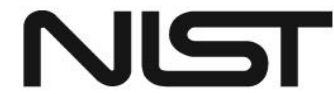

National Institute of Standards and Technology U.S. Department of Commerce 


\section{Survey of Federal Community Resilience Programs and Available Resilience Planning Tools}

Prepared for U.S. Department of Commerce

Engineering Laboratory National Institute of Standards and Technology

Gaithersburg, MD 20899

Thomas Olszewski

Irina Liu

Allison Cunningham

IDA Science and Technology Policy Institute

This publication is available free of charge from:

https://doi.org/10.6028/NIST.GCR.21-027

February 2021

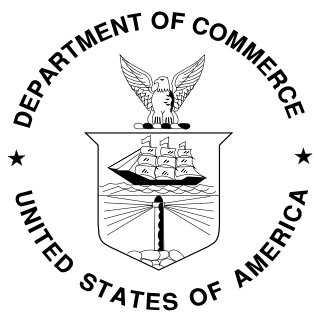

U.S. Department of Commerce Wynn Coggins, Acting Secretary

National Institute of Standards and Technology James K. Olthoff, Performing the Non-Exclusive Functions and Duties of the Under Secretary of Commerce for Standards and Technology \& Director, National Institute of Standards and Technology 


\section{Executive Summary}

\section{Introduction}

The National Institute of Standards and Technology (NIST)'s Community Resilience Program conducts research that advances the practice and standards for community resilience planning. As part of this effort, NIST is interested in understanding the range of published frameworks, data, software, and tools designed to enable effective resilience planning. NIST uses the definition of resilience established in PPD-8 (March 2011) and PPD-21 (February 2013): "the ability to prepare for anticipated hazards, adapt to changing conditions, and withstand and recover rapidly from disruptions. Activities, such as disaster preparedness-which includes prevention, protection, mitigation, response, and recovery - are key steps to resilience." To this end, NIST requested that the Science and Technology Policy Institute (STPI):

- Characterize the programs (and their associated requirements) those Federal agencies with missions relevant to community resilience and disaster recovery offer to community stakeholders;

- Analyze the current state of software, tools, and data availability for meeting Federal resilience program requirements; and

- Identify next steps to advance understanding of community use of Federal programs and resilience tools.

NIST requested this work to inform the continuing development of its community resilience research with the goal of increasing the accessibility and utility of future research data and tools by community end-users and the organizations that support them.

\section{Methods and Data}

Two datasets were assembled, one compiling Federal resilience programs and the other resilience-focused tools. The programs dataset was developed using publicly available information complemented by discussions with Federal program managers. It focuses exclusively on Federal programs that provide resources that communities must apply to receive (e.g., financial, technical, equipment); it does not cover the numerous Federal activities and efforts that manage regulations, set standards, and carry out research and development relevant to community resilience. The tools dataset was assembled based on a systematic search of the websites of Federal agencies that provide information or resources relevant to community resilience, suggestions from Federal resilience program 
managers (including NIST), and a search for data sources, software, guidebooks, and assessment protocols specifically targeting resilience that could be found on the internet. The entries in each of the two databases were sorted and compared to characterize each program and tool.

\section{Community Resilience Programs}

The overarching objective of the systematic compilation of programs is to provide a detailed overview of the landscape of Federal resources available to support community resilience. Each program was characterized based on its requirements, timing of availability (before or after a major disruption or both), targeted applicants, primary area of focus (infrastructure, economy, etc.), hazards, and aspects of resilience addressed (planning, mitigation, response, and recovery). Counts of programs in each category are displayed in Figure ES-1. 
A) Agency

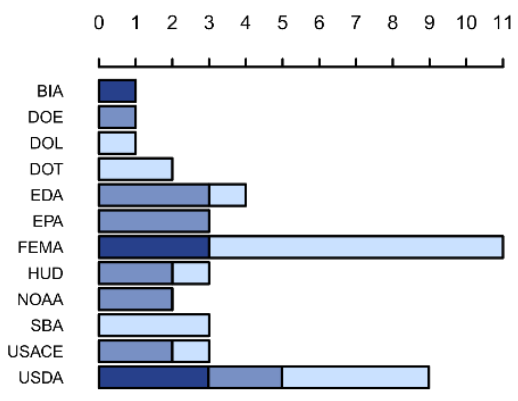

C) Applicants

$\begin{array}{llllllllllll}0 & 2 & 4 & 6 & 8 & 10 & 13 & 16 & 19 & 22 & 25 & 28\end{array}$

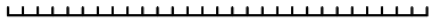

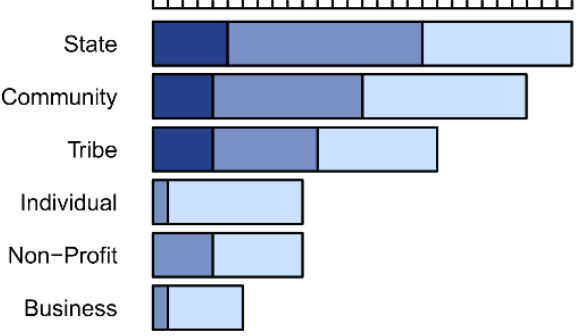

E) Hazards

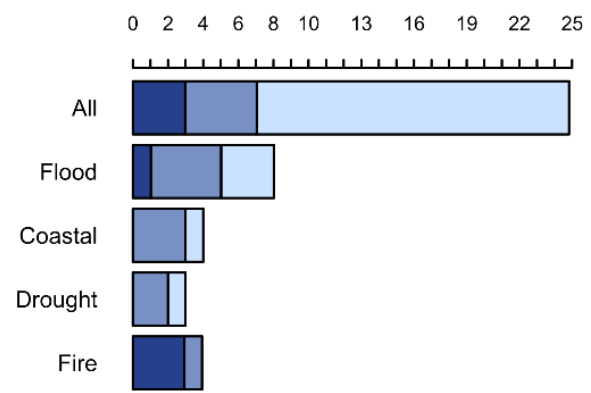

B) Requirements

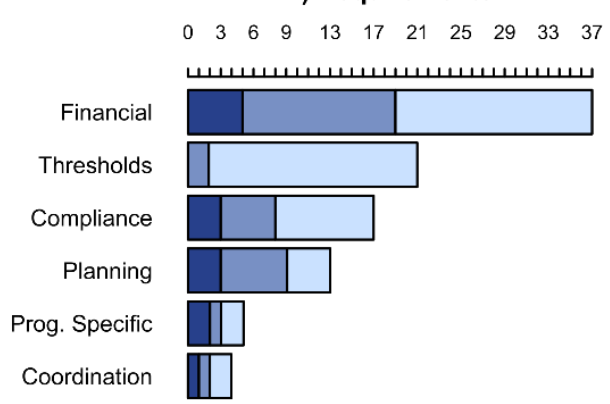

D) Focus

$\begin{array}{llllllllllll}0 & 2 & 4 & 6 & 8 & 10 & 12 & 14 & 16 & 18 & 20 & 22\end{array}$

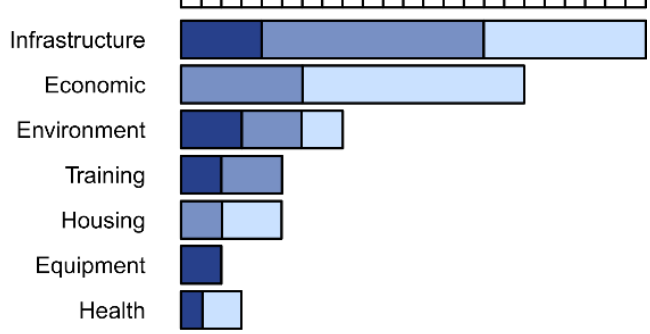

F) Aspects

$\begin{array}{lllllllll}012345678910 & 12 & 14 & 16 & 18 & 20 & 22 & 24\end{array}$

Planning

Mitigation

Response

Recovery

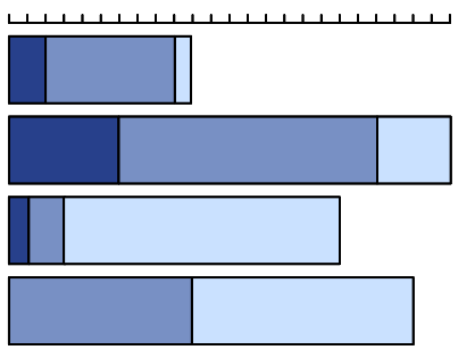

$\square$ Pre-Event $\square$ Both $\square$ Post-Event

Figure ES-1. Distributions of Federal Resilience Program Characteristics

Examination of the distribution of programs among different categories combined with discussions with agency representatives identified five principal findings:

$(P-1)$ Of the 43 identified programs, 7 are available exclusively prior to a disruption event and 22 are accessible exclusively after a disaster.

$(P-2)$ Only 5 identified programs specifically provide support for planning in contrast to 22 for mitigation, 18 for response, and 20 for recovery.

These two findings suggest that Federal programs as a whole are reactive with respect to disruptions rather than proactive.

$(P-3)$ Programs in the database addressing different aspects of resilience emphasize different requirements. 
(P-4) Planning, response, and recovery programs are not generally tied to specific hazards, whereas mitigation programs are generally tied to specific hazards.

These findings suggest that access to Federal resources depends on whether communities meet different sets of requirements for support of planning, mitigation, response, or recovery. If communities are interested in mitigation, the resources available to them may depend on the hazard they face.

$(P-5)$ Based on conversations with Federal program managers, about half of the agencies included in the database define resilience in a manner consistent with PPD-8/PPD-21, whereas the rest use alternative definitions or have no formal definition.

This finding suggests that Federal agencies' support for community resilience is refracted through the lens of their particular missions.

\section{Community Resilience Tools}

The overarching objective of compiling a database of resilience tools (software, databases, guidebooks, checklists, mapping applications) is to evaluate the resources communities can access to fulfill Federal resilience program requirements and help them take advantage of available opportunities for fostering and strengthening their resilience. Each tool was characterized based on its type (data \& model, assessment, guide), the type of provider (Federal, private sector, academic, etc.), the primary focus, and the hazard(s) addressed. Counts of tools in each category are presented in Figure ES-2.

Examination of the distribution of tools in different categories identified four principal findings: 
A) Types

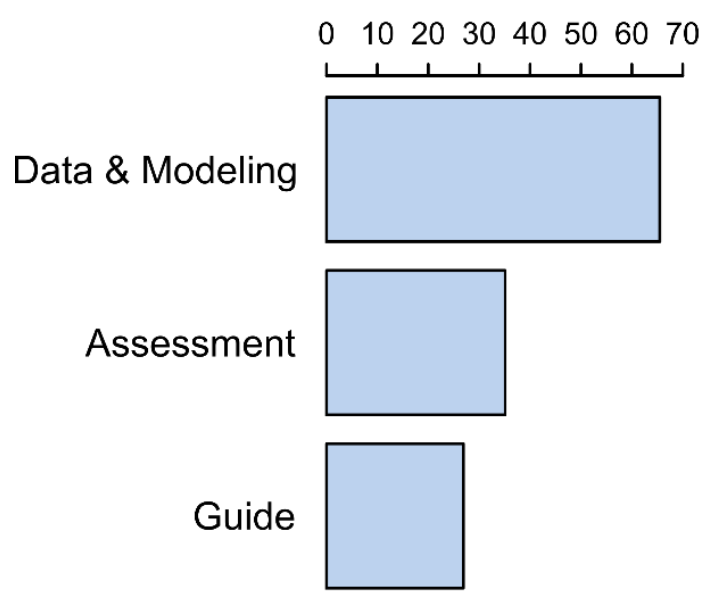

C) Hazards

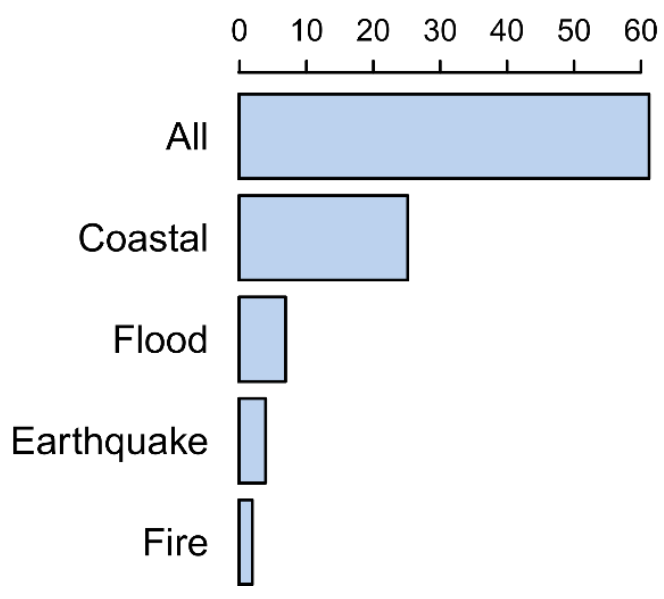

B) Providers

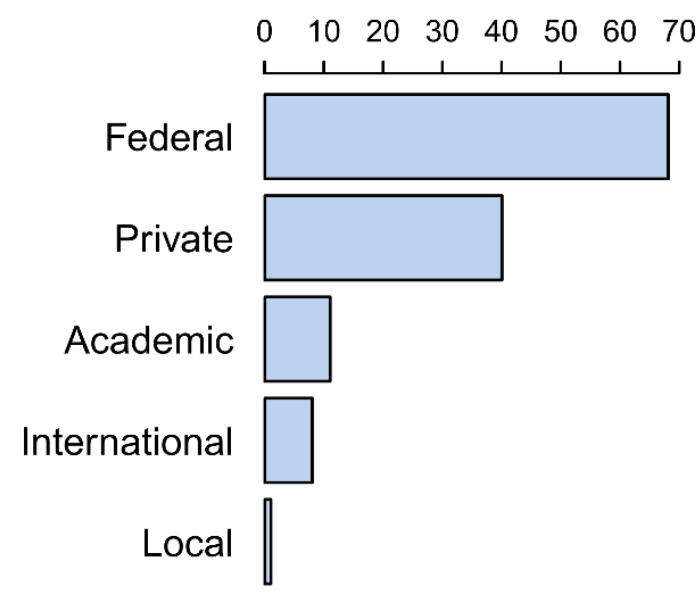

D) Focus

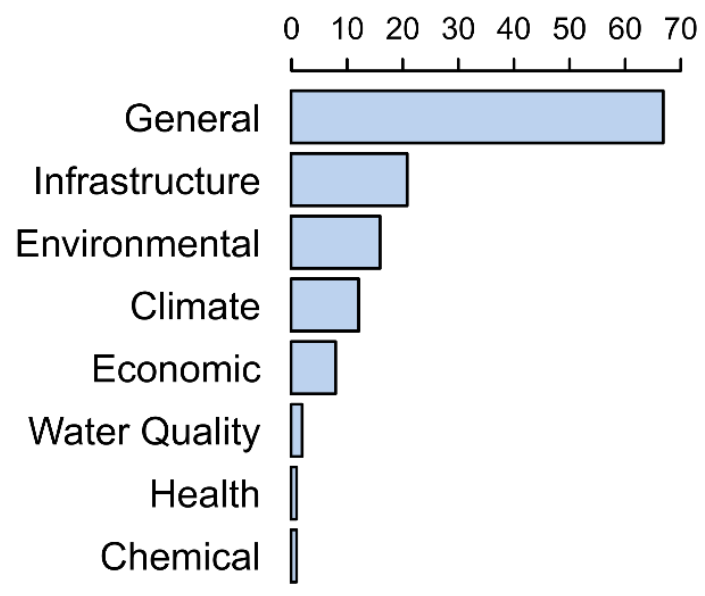

Figure ES-2. Distributions of Resilience Tool Characteristics

(T-1) Most resilience tools do not target specific Federal programs or requirements.

Resilience tools, even those provided by Federal agencies, are not aligned to specific Federal programs, and programs do not direct applicants to use specific tools to meet their requirements.

(T-2) Approximately half of the tools identified in the database (65 of 128) have a general resilience focus.

General tools are those that either provide basic information that is relevant to resilience but not specific to it (for example, digital elevation data) or address the intersection of multiple focus areas, resilience aspects, and hazards. The large number of general tools suggests that providers, both Federal and non-Federal, recognize that fostering community 
resilience requires not just supporting individual projects and activities, but ensuring that these various components are integrated and mutually supportive.

(T-3) Of the tools with focus areas more specific than the general category, 45 address focus areas also targeted by Federal programs (infrastructure, environment, economy, health) and 16 address focus areas not targeted by Federal programs (water quality, climate, chemical).

Only about a third of the tools identified in this study address resilience focus areas that are also addressed by the Federal programs included in this study.

(T-4) Both Federal agencies and the private sector provide numerous data and modeling tools (37 and 20, respectively). However, Federal agencies offer more guide tools (18) than assessment tools (10), whereas the private sector offers more assessment tools (13) than guide tools (7).

The tools provided by the private sector differ from those provided by Federal agencies: both distribute data and modeling tools that deliver fundamental information needed to address community resilience, but Federal agencies additionally tend to issue guidance documents providing strategies for framing resilience, whereas the private sector tends to provide assessments aimed at helping communities evaluate their circumstances or state of resilience.

\section{Discussion and Future Research}

A challenge that emerged in the effort to characterize resilience programs and tools is the degree of ambiguity in the way the term resilience is understood by various stakeholders. The definition used in this study - "the ability to prepare for and adapt to changing conditions and withstand and recover rapidly from disruptions"-is based on two Presidential Policy Directives (PPD-8 and PPD-21) that both put a strong emphasis on national preparedness and protection. However, the term "resilience" can be understood more broadly to include concepts like sustainability, adaptation, and efficiency as well as mitigation, response, and recovery. The result is that some Federal programs that address resilience in the broader sense are not strictly aligned with PPD-8/PPD-21 or are not integrated into the existing National Planning Frameworks. ${ }^{1}$

Next steps to advance understanding of community use of Federal programs and resilience tools could include: 1) expanding the databases to include programs and tools that address resilience-relevant topics like sustainability, efficiency, and adaptability, and 2) getting a perspective from communities on which tools and resources they actually use,

\footnotetext{
${ }^{1}$ https://www.fema.gov/national-planning-frameworks
} 
their ability to implement available tools, and whether available tools and programs meet their needs.

\section{Acknowledgements}

IDA STPI gratefully acknowledges the input and review provided by the federal agencies addressed in this report and the guidance and input of Therese McAllister (NIST Technical Point of Contact) and Christopher Clavin (NIST) throughout the project. 


\section{Contents}

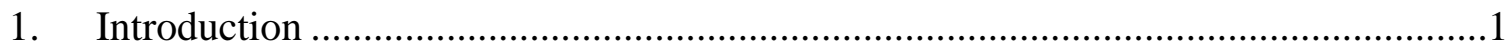

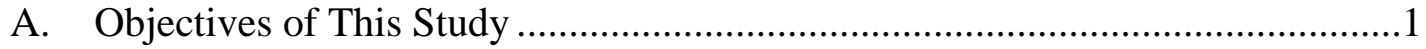

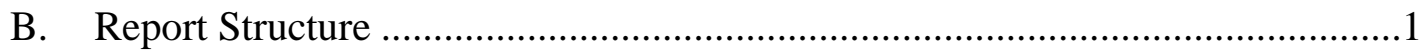

C. Federal Policies and Authorities Pertaining to Resilience ................................2

D. How Federal Programs Support Community Resilience .................................4

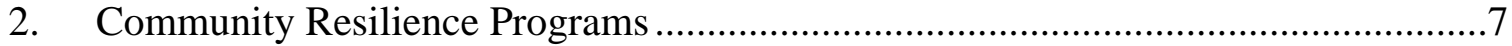

A. Objectives ..............................................................................................

B. Assembling the Database of Federal Resilience Programs .............................. 7

C. Characterizing Federal Community Resilience Programs ................................9

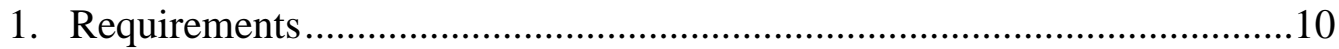

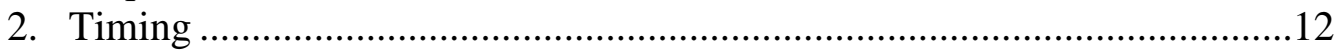

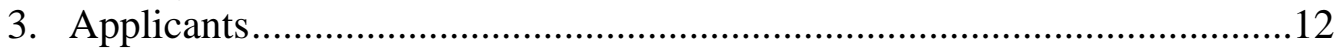

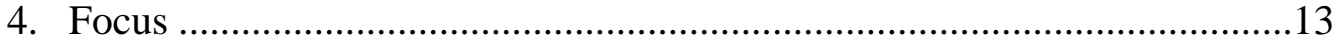

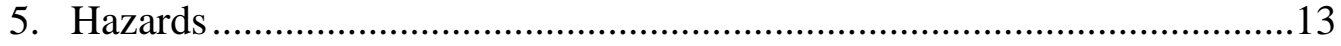

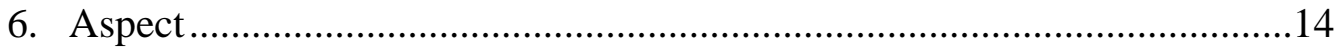

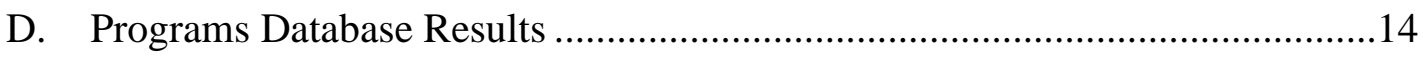

1. Distribution of Programs Among Factors ................................................14

2. Interactions Between Resilience Program Factors ....................................19

E. Discussions with Resilience Program Managers...........................................21

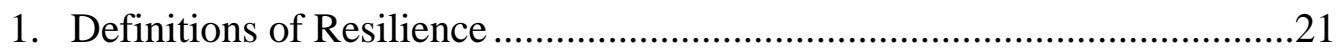

2. The Role of Resilience in Evaluating Program Outcomes ........................22

3. Outreach and Dissemination of Programs ..............................................24

4. Challenges Reported by Federal Resilience Programs...............................24

5. Importance of Local Presence and Cooperation.......................................25

6. Mechanisms for Interagency Coordination .........................................26

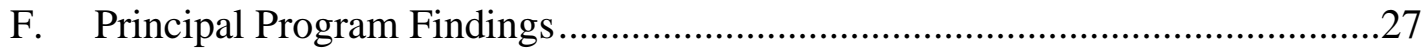

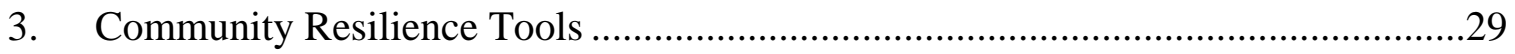

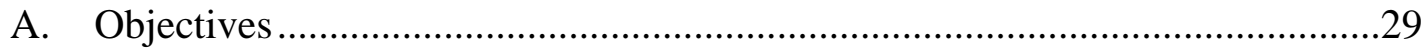

B. Assembling the Database of Resilience Tools ...............................................29

C. Characterizing Resilience Tools................................................................29

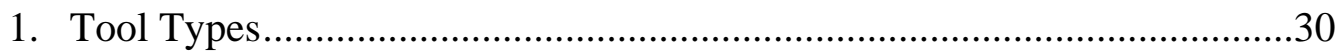

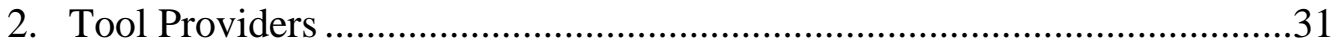

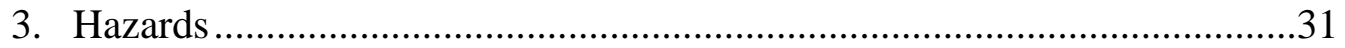

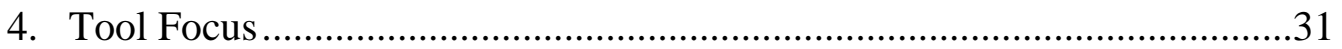

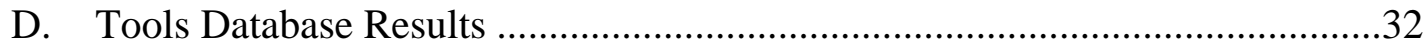

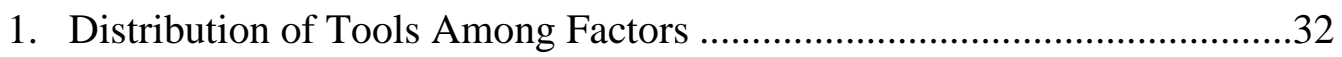

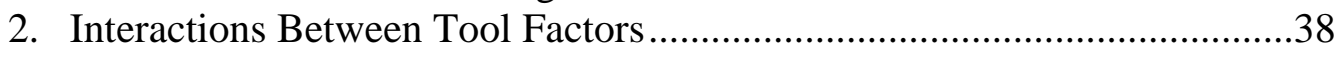




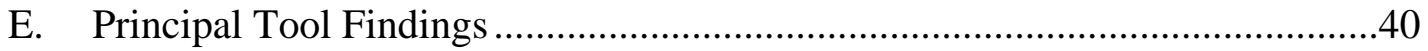

4. Discussion and Future Research.......................................................................

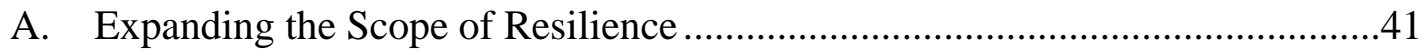

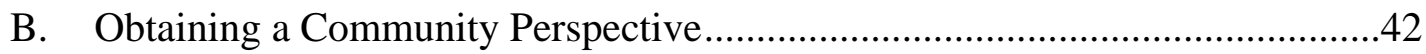

Appendix A. Discussion Protocol for Federal Program Managers................................. A-1

Appendix B. Federal Community Resilience Program Profiles ……………………….... B-1

Appendix C. Descriptions of Variables in Program Database .............................................

Appendix D. Program Coding Table ……………………....................................... D-1

Appendix E. Descriptions of Variables in Program Coding Table..................................E-1

Appendix F. Community Resilience Tools Database ……………………..................F-1

Appendix G. Descriptions of Variables in Resilience Tools Database ........................... G-1

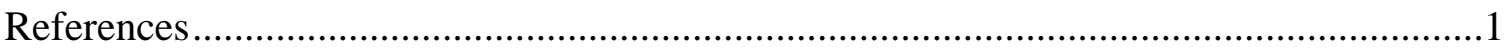

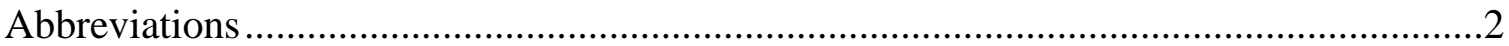




\section{Introduction}

\section{A. Objectives of This Study}

Enhancing community resilience to natural hazards requires close cooperation among numerous stakeholders-Federal, State, and tribal governments, local municipalities, businesses, non-governmental organizations, and individuals - to prepare and plan before a disruption and manage recovery and response afterwards. At the Federal level, numerous agencies have authorities and missions to facilitate and incentivize resilience planning and disaster recovery at the community level. The National Institute of Standards and Technology (NIST) is assembling a portfolio of frameworks, data, software, and other tools to reduce technical and administrative barriers to communities' efforts in resilience planning and implementation (http://www.nist.gov/topics/community-resilience).

To this end, NIST requested that the Science and Technology Policy Institute (STPI)

- characterize the programs (and their associated requirements) those Federal agencies with missions relevant to community resilience and disaster recovery offer to community stakeholders;

- analyze the current state of software, tools, and data availability for meeting Federal resilience program requirements; and

- identify next steps to advance understanding of community use of Federal programs and resilience tools.

This work is intended to inform the continuing development of NIST's community resilience resource portfolio with the goal of maximizing its usefulness for communities by ensuring alignment with other Federal agency products and program requirements.

\section{B. Report Structure}

Chapter 1 includes a brief review of the legislation and executive branch actions that establish the definition of resilience in the Federal context. It also provides a working definition for what constitutes a community and describes how the Federal Government acts to support community resilience.

Chapter 2 presents a database of Federal programs to which communities can apply for resources to strengthen their resilience. The aim is to characterize the landscape of Federal resilience programs in terms of who has access to them, what applicants can use the resources for, and what requirements they must fulfill to obtain resources. 
Chapter 3 presents a database of publicly available tools that communities can use to strengthen their resilience. The aim is to characterize tools in terms of what components of resilience they address and what communities can use them to do.

Chapter 4 reviews some of the challenges trying to understand how the resilience needs of communities are met by Federal programs and discusses possible future research directions extending the methods and findings of this study.

\section{Federal Policies and Authorities Pertaining to Resilience}

Helping communities prepare for natural disasters and providing support for them to respond when major disruptions occur has long been a focus of U.S. government policy, but over the past decade or so, policy makers have begun to think in terms of resilience,

the ability to prepare for anticipated hazards, adapt to changing conditions, and withstand and recover rapidly from disruptions. Activities, such as disaster preparedness - which includes prevention, protection, mitigation, response, and recovery—are key steps to resilience (NIST 2019).

Although Federal legislation addressing disaster recovery and other aspects of resilience dates back decades, the current foundation of authority is the Robert T. Stafford Disaster Relief and Emergency Assistance Act of 1988, which was designed to provide

an orderly and continuing means of assistance by the Federal Government to State and local governments in carrying out their responsibilities to alleviate the suffering and damage which result from [major] disasters. ${ }^{2}$

In addition to providing Federal resources for disaster relief, subsequent amendment of the Stafford Act expanded its scope beyond a response role to include encouraging investment in hazard mitigation and coordination of disaster preparedness and assistance plans (Moteff 2012).

The second substantial piece of legislation governing resilience at the Federal level is the Homeland Security Act of 2002, which created the Department of Homeland Security (DHS). ${ }^{3}$ Although DHS was originally established in response to the $9 / 11$ terrorist attacks, it subsumed a number of pre-existing Federal agencies, including the Federal Emergency Management Agency (FEMA), that retained their missions relating to natural disasters. Although their responsibilities around mitigation, planning, response, recovery, and coordination remained, the creation of the new department modified how they carry out their missions (Humphreys 2019).

2 The Stafford act is available at https://www.fema.gov/media-library-data/1582133514823be4368438bd042e3b60f5cec6b377d17/Stafford_June_2019_508.pdf

3 The act is available at https://www.dhs.gov/sites/default/files/publications/hr_5005_enr.pdf 
Most recently, in response to the hurricanes and wildfires of 2017, Congress passed the Disaster Recovery Reform Act (DRRA) of 2018, ${ }^{4}$ which addresses resilience in several ways. First, amendment of the Stafford Act by the DRRA has resulted in the establishment of the Building Resilient Infrastructure and Communities (BRIC) program, ${ }^{5}$ which replaces FEMA's Pre-Disaster Mitigation program and is intended to promote investment in mitigation before a hazard event. The Federal Insurance and Mitigation Administration estimates that as a result of changes stemming from the passage of the DRRA "approximately \$300-500 million could be made available annually for pre-disaster hazard mitigation measures, with significantly greater amounts following years with catastrophic disasters (Currie 2019)." The legislation also authorizes the use of public assistance funding to upgrade disaster damaged facilities to increase their resilience and mandates that funding through FEMA's Hazard Mitigation Grant program be used to increase resilience to future damage, hardship, loss, or suffering. FEMA published the rules for the BRIC program in 2020.

In addition to legislation, two Presidential Policy Directives (PPDs) specifically address resilience and identify it as a Federal priority. Issued in 2011, PPD-8 ("National Preparedness") is

aimed at strengthening the security and resilience of the United States through systematic preparation for the threats that pose the greatest risk to the security of the Nation, including acts of terrorism, cyberattacks, pandemics, and catastrophic natural disasters. ${ }^{6}$

It provided a definition of resilience ("the ability to adapt to changing conditions and withstand and rapidly recover from disruptions due to emergencies"), called for the development of a National Preparedness System, and emphasized the whole-ofgovernment nature of resilience by making the heads of executive departments responsible for preparedness efforts consistent with their statutory roles.

The second directive, issued in 2013, PPD-21 ("Critical Infrastructure Security and Resilience") established a national policy to carry out proactive and coordinated efforts necessary "to strengthen and maintain secure, functioning, and resilient critical infrastructure." The definition of resilience that PPD-21 provides is essentially identical to PPD-8 but with an added sentence specifying "threats and incidents:"

the ability to prepare for and adapt to changing conditions and withstand and recover rapidly from disruptions. Resilience includes the ability to

4 https://www.fema.gov/disaster-recovery-reform-act-2018; the Disaster Recovery Reform Act of 2018 was signed into law as part of the Federal Aviation Administration Reauthorization Act of 2018. For more on BRIC, see https://www.fema.gov/bric

6 For more on PPD-8, see https://www.dhs.gov/presidential-policy-directive-8-national-preparedness 
withstand and recover from deliberate attacks, accidents, or naturally occurring threats or incidents. ${ }^{7}$

The focus of PPD-21 is to secure critical infrastructure, but it explicitly acknowledges that this is a shared responsibility among Federal, State, local, tribal, and territorial governments as well as public and private owners of critical infrastructure-i.e., securing critical infrastructure can only be accomplished through strengthening the resilience of communities. It also defined 16 critical infrastructure sectors, many of which are rooted in resilience at the community level (for example, communications, emergency services, healthcare and public health, transportation systems, and water and wastewater systems).

In response to PPD-8 and PPD-21, DHS updated the National Infrastructure Protection Plan in 2013 (NIPP 2013), which outlines how government and private sector actors can work together to manage risks and achieve security and resilience outcomes.

In addition to the programs and policies that fall under the framework for Federal resilience established on the basis of the Stafford Act, DRRA, PPD-8, and PPD-21, which have a strong underlying emphasis on preparation and response to disasters, there are numerous Federal policies and programs that foster community resilience through the promotion of adaptability and sustainability. For example, the Energy Independence and Security Act of $2007,{ }^{8}$ the Farm Security and Rural Investment Act of 2002, ${ }^{9}$ and the Federal Water Pollution Control Act of $2002^{10}$ provide guidance and authorization for agencies and programs that promote practices and provide resources that strengthen elements of community resilience but do not emphasize mitigation against and recovery from disasters.

\section{How Federal Programs Support Community Resilience}

The legislation and PPDs that establish the high-level framework for Federal resilience policy largely focus on securing the Nation, protecting critical infrastructure, and preventing the loss of life and property without explicitly defining the term community (Moteff 2012; Humphreys 2019; NASEM 2019). For the purposes of this study, a community:

7 PPD-21: https://obamawhitehouse.archives.gov/the-press-office/2013/02/12/presidential-policydirective-critical-infrastructure-security-and-resil

8 Energy Independence and Security Act: https://www.govinfo.gov/content/pkg/BILLS110hr6enr/pdf/BILLS-110hr6enr.pdf

9 Farm Security and Rural Investment Act: https://www.govinfo.gov/content/pkg/PLAW107publ171/pdf/PLAW-107publ171.pdf

10 Federal Water Pollution Control Act: https://www.epa.gov/sites/production/files/201708/documents/federal-water-pollution-control-act-508full.pdf 
"refers to a place designated by geographical boundaries that functions under the jurisdiction of a governance structure, such as a town, city, or county. It is within these places that most people live, work, play, and build their futures. Each community has its own identity based on location, history, leadership, population, and available resources. Successful communities provide their members with the means to meet essential needs and to pursue their interests and aspirations" (NIST 2016).

Communities are not defined by their size or setting: they can be rural, urban, suburban, or mixed; they can span geographic areas ranging from less than one to hundreds of square miles; and they can include populations from a few dozen people to major metropolitan corridors with millions of inhabitants. Rather, in the context of resilience, what makes a community is a shared risk in the face of a hazard and a network of relationships that allows preparation and response. Communities can be represented by governmental or municipal entities (for example, States, counties, cities, townships, etc.) but they can also be represented by non-governmental organizations representing common interests.

The most visible resilience-related service provided by Federal agencies to communities is the direct delivery and coordination of aid in the immediate aftermath of a natural disaster. However, Federal agencies also provide numerous other avenues of support for the development of community resilience. Agencies can provide grants and loans to help individuals, businesses, and communities recover and rebuild after a natural disaster; often these resources provide the opportunity to upgrade damaged infrastructure and remediate compromised environments to improve the community's resilience against future disruptions. Numerous agencies also provide grants and loans to help communities mitigate or avoid the consequences of a major disruption, often resulting in strengthening a community's economy, health, and security under normal, non-disruptive conditions. Many Federal grant and loan programs can be directly accessed by individuals and businesses, whereas others are awarded to States or non-profit organizations to manage and disburse.

In addition to providing monetary resources, some Federal agencies also provide equipment. For example, the United States Forest Service Program provides surplus equipment and firefighting apparatus through either its Federal Excess Property Program or Firefighter Property Program. Communities can qualify for Federal grants or loans to buy equipment that enhances preparedness and resilience, but many Federal programs provide equipment directly, particularly if placing it with a community will also strengthen the resilience of Federal assets like National Forests and Grasslands. The Volunteer Fire Assistance program provides monetary assistance in the form of grants to rural fire departments in communities that have populations less than 10,000 per the latest U.S. Census. The recipients can use the funding to purchase equipment and apparatus as well as cover the cost of training. The Federal Excess Property Program and the Firefighter Property Program managed by the U.S. Forest Service assists communities in acquiring 
surplus equipment that can be used to support emergency response. (https://www.fs.usda.gov/managing-land/fire/fepp)

Lastly, some agencies, particularly those addressing large, regional infrastructure projects like the U.S. Army Corps of Engineers and the Federal Highway Administration, provide extensive technical and planning assistance to communities, bringing community officials into the process of laying out and designing regional infrastructure projects. 


\section{Community Resilience Programs}

\section{A. Objectives}

The overarching objective of this part of the study is to produce a systematic compilation of Federal programs that provide resources that must applied for (grants, loan guarantees, equipment, training, etc.) in support of any aspect of community resilience, including preparing for future disruptive events, investing in new or upgraded infrastructure and building stock, strengthening community social networks, conserving ecosystems, and ensuring that critical facilities and services are available in the wake of any kind of event that disrupts the normal functioning of the community. The resulting database provides an overview of Federal community resilience programs based on the aspects of resilience they support, hazards they address, requirements they mandate, and stakeholders they serve.

\section{B. Assembling the Database of Federal Resilience Programs}

The initial list of Federal programs that offer support for community resilience was based on a systematic search of the websites of Federal agencies and grants.gov. Only programs that offer some form of material, personnel, or funding support that communities must apply to receive and were active at the time the search was conducted (summer, 2019) were included. Products that agencies share freely-for example, guidebooks, databases, and visualization software - that do not require applicants to qualify for were considered tools and are addressed in the next chapter. As a consequence, numerous Federal programs that actively address national and community resilience through research, development of analytical tools, setting building codes and standards, and creating policy (for example, the Department of Energy's North American Energy Resilience Model) were not included in the program database. In addition, in order to constrain the scope of the study, programs focusing on security, which typically emphasize critical infrastructure rather than community resilience, were not included.

In addition to compiling publicly available information, a representative of each identified community resilience program, typically a program manager or an agency's designated point of contact, was approached to schedule an in-depth conversation about their program(s). Ultimately, 17 phone discussions, some covering multiple programs within an agency, were carried out between May 12 and July 15, 2019 (Table 1). 
Contacting Federal agencies had two main purposes. The first was to confirm and fill gaps in information that was initially gleaned from public sources. These conversations also provided leads on additional resilience programs.

Table 1. Federal Agencies/Offices Contacted for Study

\begin{tabular}{|c|c|}
\hline Agency & Office \\
\hline $\begin{array}{l}\text { Environmental Protection } \\
\text { Agency (EPA) }\end{array}$ & Office of Wastewater Management \\
\hline $\begin{array}{l}\text { Department of Energy } \\
\text { (DoE) }\end{array}$ & State Energy Program \\
\hline $\begin{array}{l}\text { Department of Housing } \\
\text { and Urban Development } \\
\text { (HUD) }\end{array}$ & Office of Block Grant Assistance \\
\hline $\begin{array}{l}\text { Department of Commerce } \\
\text { (DOC) }\end{array}$ & $\begin{array}{l}\text { Economic Development Administration (EDA) } \\
\text { National Oceanic and Atmospheric Administration } \\
\text { (NOAA) Office for Coastal Management }\end{array}$ \\
\hline $\begin{array}{l}\text { U.S. Department of } \\
\text { Agriculture (USDA) }\end{array}$ & $\begin{array}{l}\text { Natural Resources Conservation Service (NRCS) } \\
\text { Farm Service Agency (FSA) } \\
\text { Forest Service (FS) }\end{array}$ \\
\hline $\begin{array}{l}\text { Department of Homeland } \\
\text { Security (DHS) }\end{array}$ & $\begin{array}{l}\text { Federal Emergency Management Agency (FEMA) } \\
\text { FEMA Recovery Directorate } \\
\text { FEMA Federal Insurance and Mitigation } \\
\text { Administration } \\
\text { FEMA National Preparedness Directorate } \\
\text { Infrastructure Security Division }\end{array}$ \\
\hline $\begin{array}{l}\text { Small Business } \\
\text { Administration (SBA) }\end{array}$ & Office of Disaster Assistance \\
\hline $\begin{array}{l}\text { Department of the Interior } \\
\text { (DOI) }\end{array}$ & Bureau of Indian Affairs (BIA) Tribal Resilience \\
\hline $\begin{array}{l}\text { U.S. Army Corps of } \\
\text { Engineers (USACE) }\end{array}$ & Research and Development Directorate \\
\hline $\begin{array}{l}\text { Department of } \\
\text { Transportation (DOT) }\end{array}$ & $\begin{array}{l}\text { Federal Transit Administration (FTA) } \\
\text { Federal Highway Administration (FHWA) }\end{array}$ \\
\hline
\end{tabular}

The second purpose was to get a sense of how program managers perceive community resilience and to identify cross-cutting themes among Federal programs and agencies. The discussion template (Appendix A) included questions about:

- how the agency or program defines resilience;

- the program's goals with respect to resilience;

- how the program measures resilience and resilience outcomes; 
- communication and outreach activities associated with the program;

- the degree and nature of interagency coordination; and

- challenges and successes in carrying out the program and achieving its goals.

The discussions were fluid and focused on the information most relevant for each agency or office rather than strictly adhering to the template.

After finalizing the list of programs, each one was characterized in terms of what kinds of resources it provides, what aspects of resilience it addresses (planning, mitigation, response, and recovery), who can apply, what hazards it targets, and its particular focus areas (for example, infrastructure, economy, etc.) based on information available from program websites, notices of funding opportunities, statutes and authorities, and appropriation and funding guidelines (Appendix B). The full database of programs and explanation of terms used to describe them are provided in Appendices $\mathrm{C}$ and $\mathrm{D}$.

Agency points of contact were asked to review the characterization of the programs. In total, 13 of 17 Federal offices with programs in the database provided reviews.

\section{Characterizing Federal Community Resilience Programs}

In order to create a framework to compare and contrast the wide variety of Federal programs supporting community resilience, they were characterized based on categories in six factors (Figure 1):

1. requirements an applicant must fulfill to qualify for program resources;

2. the timing of the program relative to a disruption event;

3. the applicants targeted by the program;

4. the focus areas of the program's support (for example, infrastructure, economy, etc.);

5. the hazard(s) the program targeted; and

6. the aspect(s) of resilience addressed by the program (planning, mitigation, response, recovery).

The categories within each factor were derived from empirical examination of the programs in the database rather than from a predetermined classification. This approach streamlined subsequent analyses by eliminating potential categories that did not apply to any Federal programs identified in this study. For example, natural hazards are clearly much more diverse than the four types identified here (floods, coastal hazards, droughts, and wildfires), but these are the only specifically identified hazards that programs in the database targeted; events such as earthquakes, severe storms, pandemics, and economic crashes clearly affect communities, but no programs specifically targeting them were 
identified. (Note that hazards that are not specifically targeted are still covered by programs applicable to any hazard without restriction to type.)

In addition, categories within each factor are not necessarily mutually exclusive. For example, a program can provide support for both infrastructure and training, can be used for both mitigation and response, and could target States, communities, and non-profit organizations.

The resulting framework provides a means of sorting and organizing the programs identified in this work but should not be considered universally applicable. Any interpretations or relationships presented below apply only to the programs included in the database.

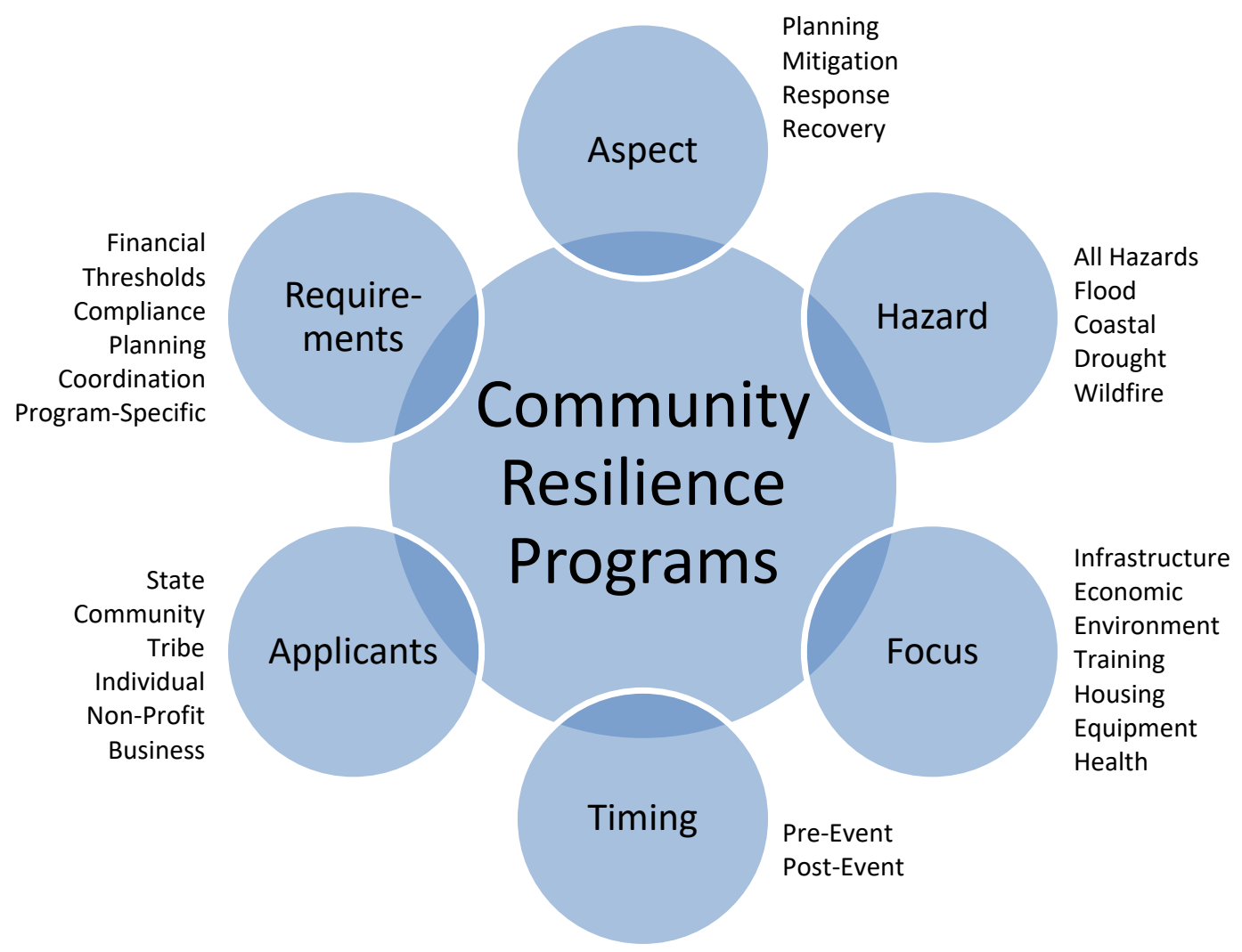

Figure 1. Factors and Categories Used to Characterize Federal Community Resilience Programs

\section{Requirements}

One of the primary goals of this study is to identify requirements that communities must fulfill in order to apply for and receive support from Federal resilience programs. Requirements for individual programs tend to be very program-specific in detail, but at a high-level fall into five broad categories: financial, threshold, compliance, planning, and coordination (Table 2). 
Table 2. Resilience Program Requirements

Financial Requirements: Applicant must meet some standard of financial or credit capacity in order to qualify. Specific financial requirements include:

Cost-Share: Applicant must bear some portion of costs

Cost-Effective: Application requires project cost evaluation criteria for work and materials

Credit History: Applicant must demonstrate credit worthiness by providing credit history

Flood Insurance: Requires existing flood insurance coverage

Financial Capacity: Requires a financial capacity evaluation to ensure applicant is able to build and maintain new or upgraded infrastructure

Credit Not Available Elsewhere: Applicant must demonstrate that credit is not available elsewhere

Threshold Requirements: Applicant must meet one or more externally determined criteria. Specific threshold requirements may include:

Disaster Declaration: Funding is only available after the President or another authorized Federal official has issued a Major Disaster Declaration

Property Damage: Applicant must document that post-event damage exceeds a specified threshold of a structure's value

Special Flood Hazard Area (SFHA): Project must be located in a SFHA, an area that is subject to a $1 \%$ or greater chance of flooding in any given year

Low-Income Community: Community qualifies for low-Income or small impoverished community status or is unable to meet Federal cost-share requirements

Compliance Requirements: Applicant must have taken actions to meet specified regulatory standards. Compliance requirements may include:

National Flood Insurance Program (NFIP): Applicant must be in good standing in the NFIP Building Code: Building codes, including international, national, or local, must be adopted Environmental Planning and Historic Preservation (EHP) Compliance: Must demonstrate Federal EHP compliance

Planning Requirements: Applicant must have approved plans or a planning process in place prior to qualifying for a program. Planning requirements may include:

Existing Plan Required: Requires an existing or a new/updated regional strategy or plan addressing a program's resilience focus (for example, hazard mitigation plan for FEMA; comprehensive economic development strategy (CEDS) or equivalent plan for EDA)

Multi-Hazard Risk Assessment: Applicant must complete a hazard identification and risk assessment

Hazard Mitigation Plan: Applicant must have a plan in place to mitigate a specific hazard

Coordination Requirements: Applicant must demonstrate that resources from other sources have been requested or obtained. Coordination requirements may include:

Interagency Coordination: Applicant must coordinate and align funds with resilience projects funded by other agencies

Applied for FEMA Assistance: Some non-FEMA programs require that applicants also apply to FEMA

Program-Specific: Requirements that are not shared with other programs in the database or falling into other broad categories. This does not indicate an absence of requirements, just that a program's requirements are unique. 
A handful of Federal programs specify requirements that are particular to their own mission, do not fall within any of the broad categories, and are not shared by any other programs; these are indicated as program specific. The specific requirements and broad categories listed in Table 2 were identified based on the compilation of programs and intended to reveal similarities and differences among the programs offered by different Federal agencies. These are not intended to serve as a universal framework for resilience programs not included in this study.

\section{Timing}

The goals and requirements of many resilience programs constrain when they come into force: before a disruption (pre-event), after a disruption (post-event), or both. Pre- and post-event timing are often associated with different aspects of resilience (see section 6 . Aspect, below), with planning and mitigation occurring before an event and response and recovery afterward. However, many programs that come into effect only after an event can also provide resources for planning, mitigation, and upgrading in anticipation of future events.

\section{Applicants}

Many Federal programs specifically target particular types of applicants (Table 3). In some cases, the applicant is the direct beneficiary of support (for example, an individual receiving unemployment insurance), whereas in others, the applicant acts as an intermediary responsible for disbursing resources to the communities and individuals who are the ultimate beneficiaries. In the second case, States and non-profits acting as intermediaries may mandate additional requirements beyond those set by Federal rules.

Table 3. Applicants

State: State government and State agencies

Community: The people and institutions in a particular area of unspecified size that share risk in the face of a hazard and a network of relationships that allows preparation and response. Communities can be represented by governmental or municipal entities; for the purposes of this study, communities exclude individual States, because States are specifically designated by many Federal programs as recipients of support in the form of block grants to be further disbursed. Communities can, however, be represented by a consortium with one or more State governments participating. Tribes can access community resources, but also have access to additional tribal-specific resources.

Tribe: Federally recognized tribal governments

Individual: A single person representing himself or herself

Non-Profit: A non-governmental organization that receives support from a Federal program to support community facilities, social institutions, or residents. When non-profit organizations receive Federal loans or grants to repair property or replace equipment they own, they are considered businesses for the purposes of this study.

Business: A company or corporation representing itself; not constrained by size. 


\section{Focus}

The Federal programs included in the database support seven focus areas for community resilience (Table 4): infrastructure, economy, environment, training, housing, equipment, and health. Many of these categories include more specific areas of concentration, for example, infrastructure covers power, water, sewage, transportation (roads, railroads, ports, etc.), and communication, each of which may individually be supported by separate Federal agencies and programs. The focus areas in Table 4 are at a level of resolution that was found to balance generality and specificity, allowing useful comparison of the programs included in the database.

\section{Table 4. Focus of Resilience Programs}

Infrastructure: Building, protecting, improving machinery and facilities (for example, buildings, roads, water, sewage, power) that enable the vital functions of a community's governance, public health, and economy; infrastructure can be publicly or privately owned.

Economy: Protection and recovery of fiscal, financial, and commercial activities within a community, including public expenditure, individual income and employment, and business activity

Environment: Management and restoration of natural resources promoting the resilience of a community

Training: Preparing community managers, leaders, and residents to respond to natural disasters or other disruptions of the community

Housing: Residential dwellings occupied by individuals and families

Equipment: Purchase or acquisition of equipment needed to improve a community's resilience in the face of natural disasters or other disruptions

Health: Help the residents of a community prepare for, cope with, and recover from the mental, physical, and other stresses experienced in the aftermath of a natural disaster or other disruption

\section{Hazards}

Many of the resilience programs identified in this study provide communities support against all types of natural hazards, but some target specific kinds, namely, flood, coastal, drought, and wildfire. Hazard specificity typically reflects the particular mission of the agency providing the support. For example, the USDA Forest Service Wildland Fire Management program targets wildfires, and the U.S. Army Corps of Engineers (USACE) Flood Management Services Program targets river and coastal flooding. Resilience in the face of other types of events - such as earthquakes, tornadoes, or pandemics - was not specifically addressed by Federal programs included in this study. The coastal category spans a complex array of closely related hazards such as wind damage, flooding, and loss or movement of emergent land that are also a concern in non-coastal settings. Coastal programs address them as a suite of hazards that share a common cause and amplify each other's effects. 


\section{Aspect}

PPD-8 includes five aspects of national preparedness in the face of major disruption events: prevention, protection, mitigation, response, and recovery. ${ }^{11}$ Of these, prevention specifically addresses "those capabilities necessary to avoid, prevent, or stop a threatened or actual act of [imminent] terrorism." None of the community resilience programs considered in this report focuses on preventing an imminent act of terrorism. Protection focuses specifically on the defense and security of critical assets and leadership. Again, the community resilience programs included in the current study do not address security. The definitions of the remaining three aspects - mitigation, response, and recovery - as used in this report are adapted from PPD-8 (Table 5).

Although prevention and protection as defined in PPD-8 are of limited relevance when considering community resilience programs in the context of this study, they do highlight the importance of preparation in anticipation of future disruptions. Several Federal programs provide support to communities for resilience planning, which is included here as an additional aspect of resilience; the definition of planning in Table 5 is adapted from the National Preparedness Goal (2015).

\section{Table 5. Aspects of Resilience}

Planning: Support for carrying out a systematic process to develop executable strategic, operational, and/or community-based approaches to meet resilience objectives in the light of current and expected financial, environmental, and demographic conditions

Mitigation: Support for enhancing capabilities intended to reduce loss of life and property by lessening the impact of disasters, including community-wide risk reduction projects and improvement of the resilience of critical infrastructure and key resource lifelines

Response: Support to save lives, protect property and the environment, and meet basic human needs after an incident has occurred

Recovery: Support for capabilities necessary to assist communities affected by an incident to rebuild or enhance infrastructure systems and housing; restore health, social, and community services; promote economic development; and restore natural and cultural resources

\section{Programs Database Results}

\section{Distribution of Programs Among Factors}

The database includes 43 Federal programs that provide some form of material, financial, or personnel support to communities to strengthen their resilience. The distribution of resilience factors among programs is shown in Figure 2 (data displayed in Figure 2 are provided in Appendix E).

Of the programs in the database, 22 are exclusively available post-event, 6 are exclusively pre-event, and 14 are available both before and after a disruption (Figure 2).

11 PPD-8 is available at https://www.dhs.gov/presidential-policy-directive-8-national-preparedness 
Figure 3 indicates how pre- and post-event programs are distributed among the categories in all the other major factors. Because individual programs can be counted in more than one category, the sum totals in each factor exceed the total number programs included in the database.

Most agencies (Figure 3A) offer one to three programs, except for FEMA, which provides 11, and USDA, which provides eight. (Note that the USDA programs are offered by three different offices: the Forest Service, the Farm Service Agency, and the Natural Resources Conservation Service.) Most agencies provide support for community resilience both before and after an event, except SBA, DOT, and DOL, whose programs are exclusively post-event (Figure 3A).

Almost all the programs considered in this study enforce financial requirements such as cost-sharing or credit worthiness on the part of an applicant, and half have threshold requirements (Figure 3B). There may be exceptions; for instance, EDA is authorized to waive matching requirements in some cases. Twelve programs include planning requirements. The pre- or post-event timing of programs is not strongly associated with requirements except for thresholds, which are almost entirely tied to post-event programs (Figure 3B). However, this relationship is largely spurious because it reflects the requirement that a disaster declaration be issued or that property damage be demonstrated (Table 2) before many post-event response and recovery programs are available.

Substantially more programs are accessible to governmental entities-i.e., States, communities, and tribes - than non-governmental entities (individuals, non-profits, and businesses), although as noted above, many Federal programs funnel resources to communities, businesses, and individuals indirectly through States (Figure 3C). The timing of program availability also differs between governmental and non-governmental entities, with no exclusively pre-event programs available to businesses, non-profits, or individuals (Figure 3C). In addition, six agencies offer programs available to both governmental and non-governmental applicants, except for SBA and the USDA's Farm Service Agency which are exclusively non-governmental, and BIA, DOE, DOT, and HUD, which are exclusively governmental (Figure 2).

In terms of the focus areas, hazards, and aspects of resilience that Federal programs address, the majority target infrastructure and economy (Figure 3D), are unrestricted with respect to type of hazard (Figure $3 \mathrm{E}$ ), and tend to focus on mitigation, response, and recovery rather than planning (Figure $3 \mathrm{~F}$ ). With respect to timing of availability, programs that target specific natural hazards are more likely to be available pre-event (Figure $3 \mathrm{E}$ ) than those that serve all hazards. 
Principal Finding P-1. Of the 43 identified programs, 7 are available exclusively prior to a disruption event and 22 are accessible exclusively after a disaster.

Principal Finding P-2. Only 5 identified programs specifically provide support for planning in contrast to 22 for mitigation, 18 for response, and 20 for recovery. 


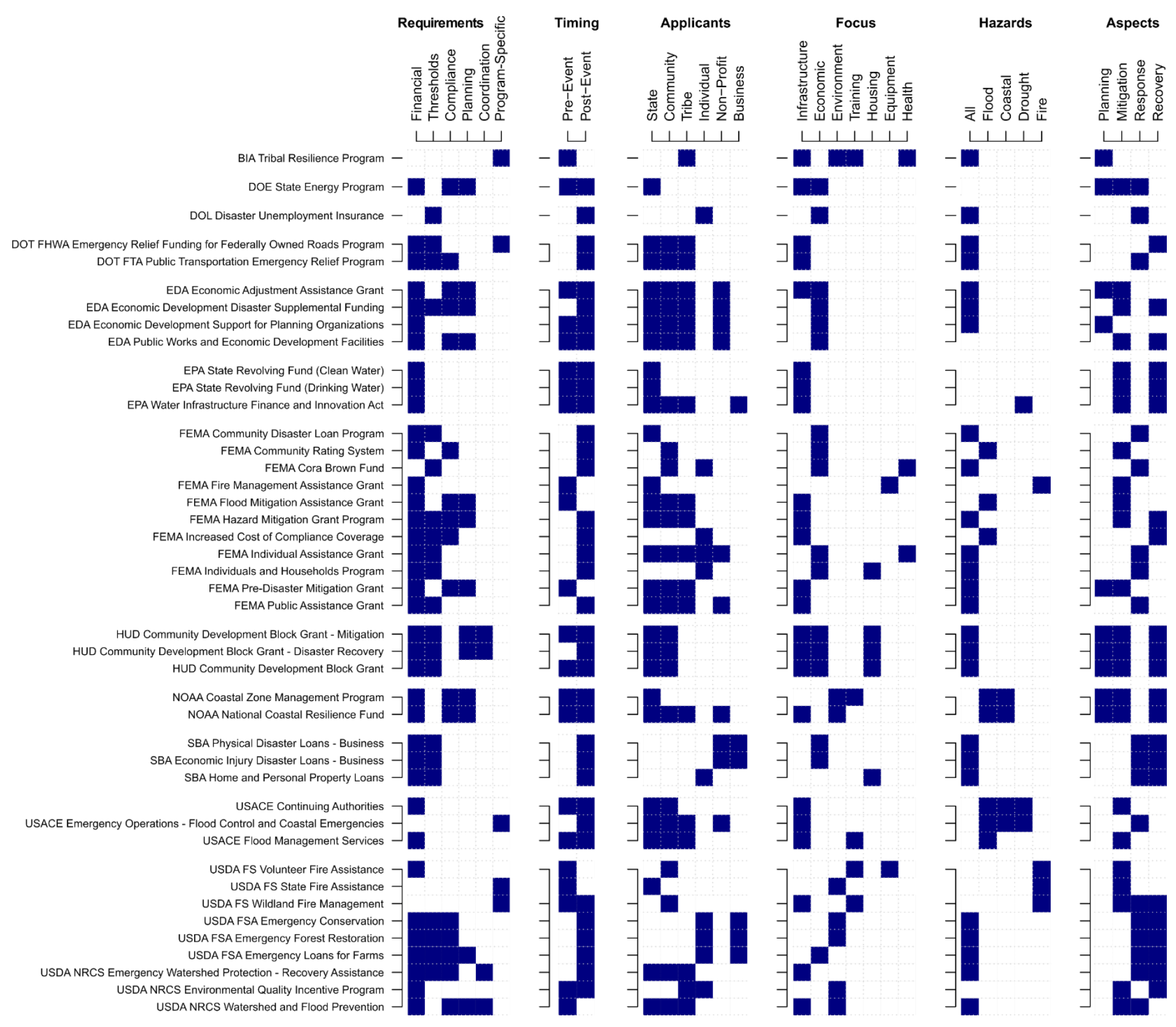

Figure 2. Characteristics of Federal Programs Included in this Study 


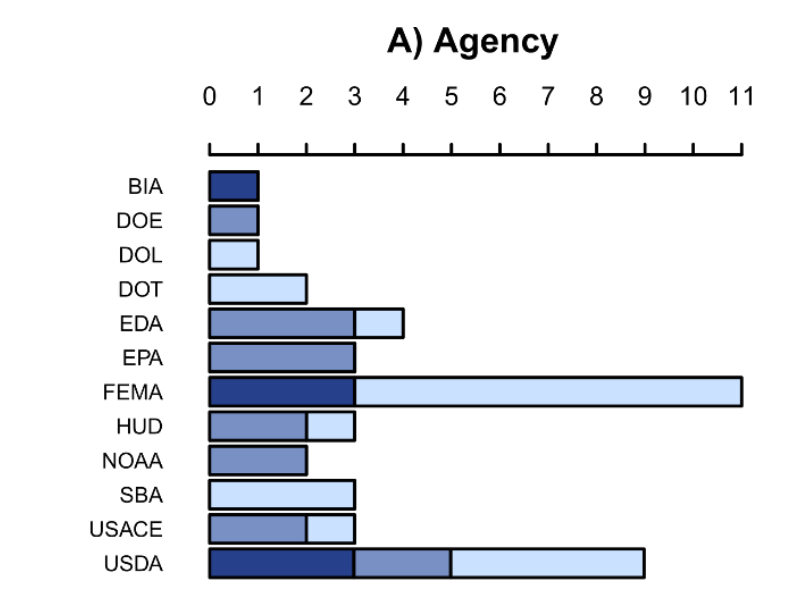

C) Applicants

$\begin{array}{llllllllllll}0 & 2 & 4 & 6 & 8 & 10 & 13 & 16 & 19 & 22 & 25 & 28\end{array}$

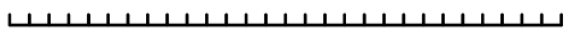

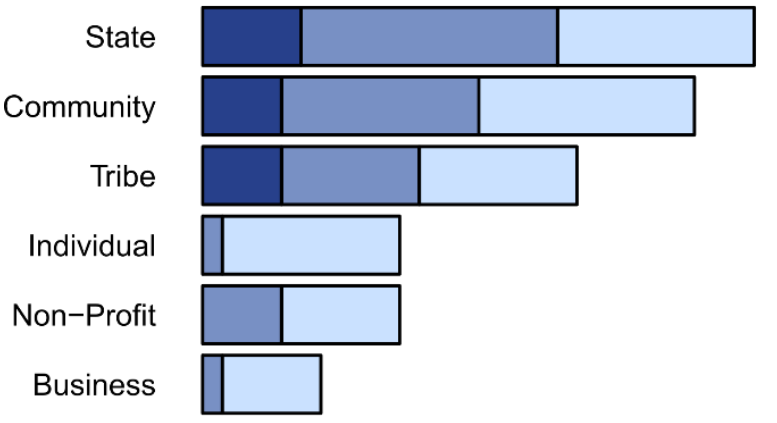

E) Hazards

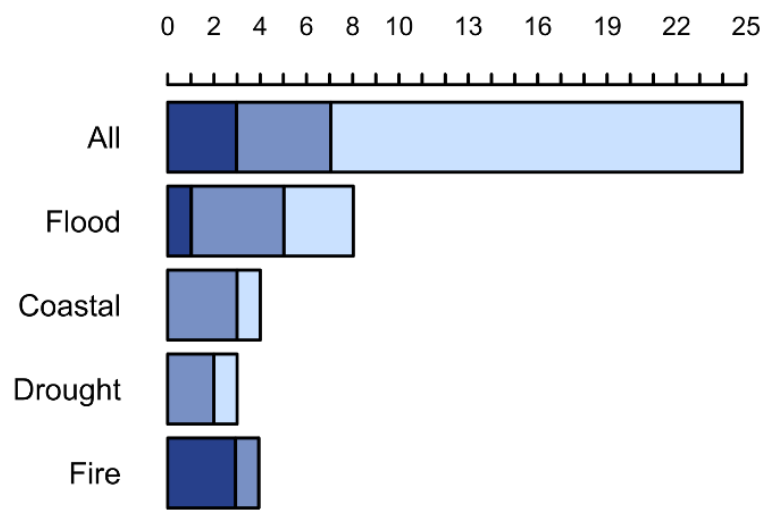

B) Requirements

$\begin{array}{lllllllllll}0 & 3 & 6 & 9 & 13 & 17 & 21 & 25 & 29 & 33 & 37\end{array}$

Financial
Thresholds
Compliance
Planning
Prog. Specific
Coordination

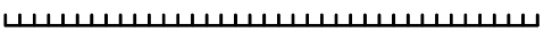

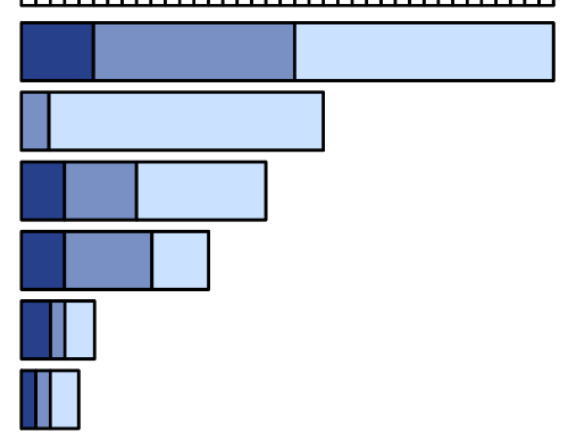

D) Focus

$\begin{array}{llllllllllll}0 & 2 & 4 & 6 & 8 & 10 & 12 & 14 & 16 & 18 & 20 & 22\end{array}$

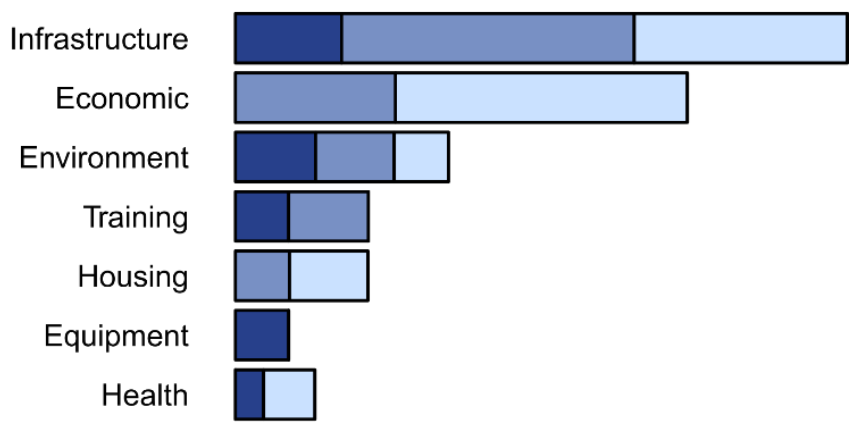

F) Aspects

$\begin{array}{llllllllll}012345678910 & 12 & 14 & 16 & 18 & 20 & 22 & 24\end{array}$

Planning

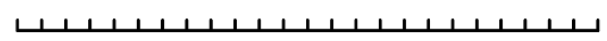

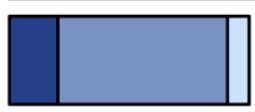

Mitigation

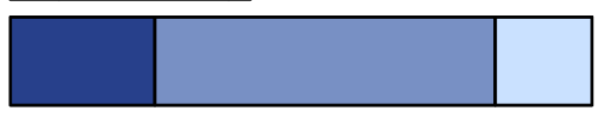

Response

Recovery
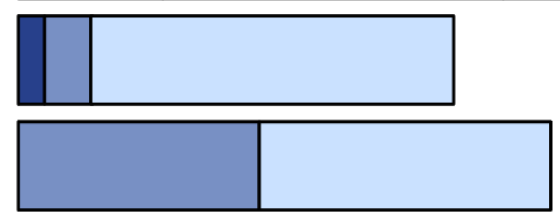

Pre-Event $\square$ Both $\square$ Post-Event

Each bar indicates the number of programs falling into a category; most programs are included in more than one category per factor.

Figure 3. Characteristics of Federal Resilience Programs 


\section{Interactions Between Resilience Program Factors}

In addition to providing a basis for evaluating the distribution of Federal resilience programs, the database also allows for analysis of interactions between factors (Figure 4). The tables in Figure 4 were selected because they suggest relationships (or the noteworthy absence of relationships) that may represent gaps in coverage or point to possible obstacles to accessing Federal support for community resilience. Combinations that did not reveal any strong relationship or showed spurious relationships resulting from the way they are defined (for example, programs that support planning tend to be pre-event) are not presented. The relationships reported here are purely descriptive and only apply to the programs included in this study; statistical significance of possible relationships was not evaluated and no inferences about possible relationships should be extrapolated beyond the programs considered in this report.

Of the comparisons that revealed factor interactions, targeted applicants appear to have a relationship with both resilience aspects and hazard types. Non-governmental applicants (individuals, businesses, and non-profits) have fewer options supporting planning and mitigation than governmental entities (States, communities, and tribes) (Figure 4A). In addition, individuals and businesses - the two categories of applicants that represent private interests rather than community or group interests - have fewer programs targeting specific hazards: only one to help individuals with floods (FEMA Increased Cost of Compliance Coverage) and one to help businesses with droughts (EPA Water Infrastructure Finance and Innovation Act) (Figure 4B). Note that both individuals and businesses still have access to multiple programs addressing any type of natural hazard.

In contrast to the apparent relationship that applicants have with resilience aspect and hazard type, program requirements do not appear to differ among applicants (Figure 4C). In general, no category of applicant is exempted from meeting some form of financial, threshold, or compliance requirement, although there is a slightly higher emphasis for individuals and businesses to meet thresholds and a slightly lower emphasis for them to meet planning requirements compared to governmental entities. There can be exceptions, such as when EDA may waive matching funds for Tribes and some other projects based on level of distress.

Lastly, programs aimed at different aspects of resilience appear to address different hazards and have different requirements. In particular, mitigation programs tend to target specific hazards, whereas planning, response, and recovery tend to offer support for any hazard (Figure 4D). With respect to requirements, recovery programs have a large number spanning financial, compliance, planning, and threshold categories. In contrast, mitigation programs have fewer threshold requirements and response programs have fewer compliance and planning requirements (Figure 4E). 
A) applicants v. aspects

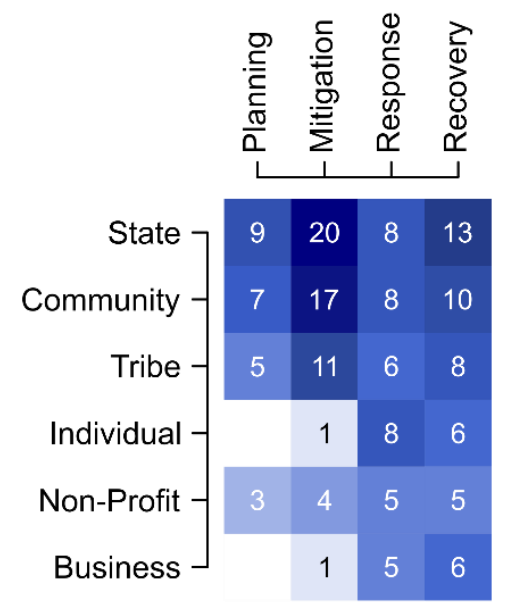

C) requirements $v$. applicants

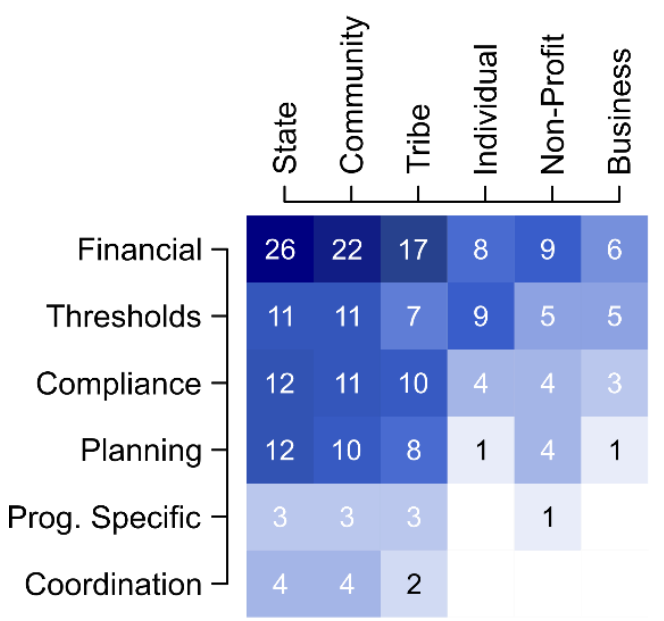

D) hazards v. aspects

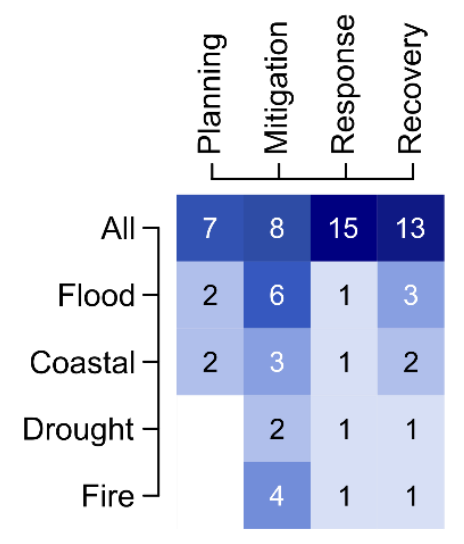

B) applicants v. hazards

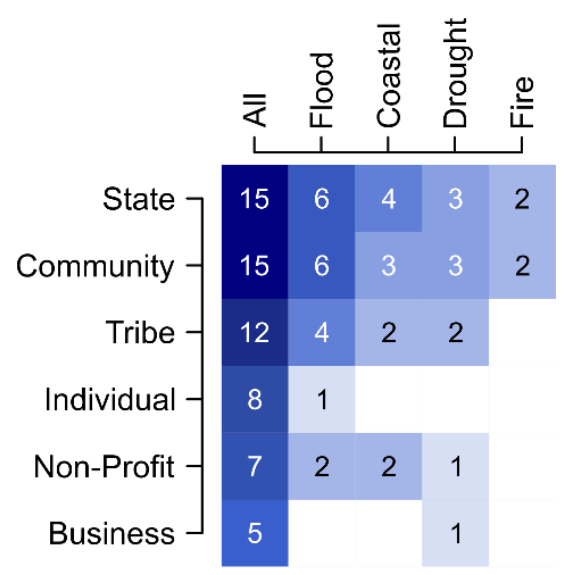


Principal Finding P-3. Programs in the database addressing different aspects of resilience emphasize different types of requirements.

Principal Finding P-4. Planning, response, and recovery programs are not generally tied to specific hazards, whereas mitigation programs are generally tied to specific hazards.

\section{E. Discussions with Resilience Program Managers}

In addition to ensuring that the information on programs was correct, Federal program managers provided their perspectives on community resilience, how their programs address resilience, and some of the challenges they face.

\section{Definitions of Resilience}

Although PPD-8 and PPD-21 establish a formal definition of resilience as it applies to Federal programs, it has been incorporated to differing degrees by different agencies in light of their particular missions and authorities. When asked about the definition of resilience used by their programs, responses fell into one of three categories (Table 6):

1. No formal definition - based on information provided by the point of contact, these agencies or sub-agencies typically either used the term resilience without having a formal definition or did not have a definition because they do not use the term resilience in their work.

2. PPD-8/PPD-21 definition - these agencies or sub-agencies use an official definition of resilience that is identical or similar to PPD-8/PPD-21.

3. Alternative definition - these agencies or sub-agencies developed their own definition of resilience that differs from PPD-8/PPD-21. For instance, the NOAA Office for Coastal Management generally uses the National Academy of Sciences ${ }^{12}$ definition of resilience: "the ability to prepare and plan for, absorb, recover from and more successfully adapt to adverse events".

\footnotetext{
12 https://www.nap.edu/catalog/13457/disaster-resilience-a-national-imperative
} 
Table 6. Definition of "Resilience" Categories with Corresponding Agency/Sub-Agency

\begin{tabular}{ll}
\hline \hline Definition Category & \multicolumn{1}{c}{ Agencies/Sub-Agencies } \\
\hline PPD-8/PPD-21 & HUD Office of Block Grant Assistance \\
Definition & FEMA Mitigation \\
& FEMA Recovery \\
& FEMA Preparedness - Infrastructure Security Division \\
& FEMA Federal Insurance \& Mitigation Administration \\
& USACE Civil Works \\
& DOT FHWA \\
& DOT FTA \\
& DOE State Energy Program \\
& EDA uses the NADO definition: "Resilience is the ability of \\
& a region or community to anticipate, withstand, and bounce \\
& back from any type of shock or disruption." \\
& NOAA uses the National Academy of Sciences definition of \\
Alternative Definition & resilience: "the ability to prepare and plan for, absorb, \\
& recover from and more successfully adapt to adverse \\
& events" \\
& USDA Farm Service Agency \\
& USDA Forest Service \\
& USDA Natural Resources Conservation Service \\
& SBA Office of Disaster Assistance \\
BIA Tribal Assistance & EPA Office of Wastewater Management \\
\hline \hline
\end{tabular}

Principal Finding P-5. Based on conversations with Federal program managers, about half of the agencies included in the database define resilience in a manner consistent with PPD-8/PPD-21, whereas the rest use alternative definitions or have no formal definition.

\section{The Role of Resilience in Evaluating Program Outcomes}

Federal agencies with programs that focus on or impact community resilience have a variety of goals and expected outcomes. Generally, program managers referred to their agency or program mission, strategic plan, appropriation or authorization language, or other authoritative guidance when asked about the goals of their programs. Agencies incorporate resilience into their goals to different degrees: some have improvement of community resilience as a main goal while others did not include it as a program goal but recognize it as a likely outcome.

Agencies display significant variation in their use of metrics to evaluate outcomes. Some agencies use detailed metrics (both resilience-related and not) while others do not report using metrics at all. Representatives of several agencies acknowledged struggling to 
create resilience metrics that measure program success, and others are in the process of developing such metrics. Metrics sometimes vary among programs within an agency. For example, FEMA collects resilience-focused metrics for some programs in certain directorates, but not for others, depending on whether resilience is a stated program goal.

Based on discussions with program managers, agencies and sub-agencies were put into one of four categories FOR metrics and their relationship to resilience (Table 7):

1. Program resilience metrics: These organizations have one or more formally defined metrics tied directly to the resilience outcomes of their program(s).

2. Agency metrics: These organizations use metrics derived from higher-level agency strategic plans or other guidance, but do not specifically target resilience.

3. Non-resilience metrics: These organizations use metrics that are specific to individual programs, but do not target resilience.

4. Other evaluation criteria: These organizations evaluate success based on agency goals or established protocols but do not use formally defined metrics.

Table 7. Agencies/Sub-Agencies Grouped into Metric Categories

\begin{tabular}{ll}
\hline \hline Definition Category & \multicolumn{1}{c}{ Agencies/Sub-Agencies } \\
\hline Program Resilience & DHS FEMA Mitigation \\
Metrics & DHS FEMA Federal Insurance and Mitigation \\
& Administration \\
& HUD Office of Block Grant Assistance \\
& USDA Natural Resources Conservation Service \\
& USDA Forest Service Agency \\
& DOI BIA Tribal Resilience \\
& USACE Civil Works \\
& DOC NOAA Office for Coastal Management \\
& DOT FTA \\
Agency Metrics & DHS FEMA Preparedness \\
& HUD Office of Block Grant Assistance \\
Non-Resilience & DOC EDA \\
Metrics & EPA Office of Wastewater Management \\
& DHS FEMA Recovery \\
Other Evaluation & USDA Farm Service Agency \\
Criteria & SBA Office of Disaster Assistance \\
& DHS Critical Infrastructure \\
\hline \hline
\end{tabular}




\section{Outreach and Dissemination of Programs}

The most common mode of outreach reported by agencies was the broad distribution of informational materials and creation of websites. Although widespread, these modes of outreach require potential applicants to find them. Representatives from several agencies with pre-event programs reported that many communities focus on resilience only after a disaster rather than planning and preparing beforehand, suggesting that it takes a disruptive event to bring resilience to the forefront of their attention.

Personal outreach was mentioned by numerous agencies as an especially effective way to inform local communities and individual stakeholders about Federal programs and to ensure that applications for resources were correctly prepared. Many agencies, such as USDA, HUD, EDA, and NOAA's Office for Coastal Management, have permanent regional or local offices with staff who interact with local communities. They are often responsible for providing information about an agency's programs through town halls, directly approaching stakeholders, helping applicants navigate resources, and meeting with individuals.

Lastly, many agencies disseminate information through partnering organizations, typically State agencies or non-governmental organizations. For example, the USDA Forest Service primary outreach effort is through the State Forestry agencies which interact directly with communities on prevention and mitigation programs for wildfire such as the Firewise USA program. EDA promotes resilience through its Planning Partners (EDDs) who develop CEDS using resilience principles. Other agencies work through State partners, who both reach out to potential recipients and allocate funding for local projects.

\section{Challenges Reported by Federal Resilience Programs}

All Federal program managers reported challenges to optimizing the effectiveness of the programs they oversee. Many challenges were specific to a particular program or agency but several common themes emerged from the discussions.

Representatives of several agencies reported that they had insufficient resources to meet demand. In some cases, this reflects high levels of demand. In other cases, uncertainty of funding allocations causes potential recipients to be unwilling to take the time and effort required to apply for support that may be delayed or cancelled. For example, BIA's Tribal Resilience program was established in 2011, but it was not until it expanded in 2014 that it was perceived by potential applicants as having sufficient stability and continuity to provide resources reliably. Additionally, tribes would like access to non-planning funds for climate resilience that support implementation of adaptation projects. The perspective may be different than what was found across federal programs because tribes may not have as easy access to many of those funds due to barriers (e.g., cost-match, or not available to tribes, etc.) or education about the programs. USDA's Natural Resources Conservation Service reported a similar difficulty: between 2009 and 2017 funding for the program was 
inconsistent, resulting in a backlog of $\$ 2$ billion for identified projects. The consequence was that partner communities either implemented projects with other sources of funding, if possible, or dropped them altogether, a clearly negative outcome.

The second common challenge is the ability of communities to meet their obligations to initiate or maintain a project. USDA, FEMA, and EDA typically require fund matching (with some exceptions, such as FEMA public assistance funds or EDA projects for tribal communities and projects that meet distress criteria), dependent on the project, which can be difficult for many communities with small populations and limited financial resources. The problem can be exacerbated during times of local economic downturns, which are often a consequence of the disasters that triggered the need for Federal resources in the first place. In addition, some agencies report that the challenge facing many communities lies not in implementing an infrastructure project itself, but rather in the ability to sustain it once it is constructed. For example, the USDA Natural Resources Conservation Service can provide support to establish projects but not for subsequent operation and maintenance, which become the responsibility of the partnering communities. USACE reports that their priorities for projects centered on flood protection and coastal maintenance may not match the priorities of their local partners, although in some cases this stems from the scope of USACE's mission more than the inability of local communities to contribute resources.

Lastly, many agencies noted that managing multiple funding sources with contrasting requirements can be a challenge for applicants. Support from different agencies often has different qualification criteria, different expectations for reimbursement (some support is awarded as a grant, whereas other support comes in the form of a loan), and different management requirements. Federal program managers reported that knitting together an optimal Federal support package from multiple agencies is often hindered by differing response speeds among agencies. For example, HUD and FEMA funds flow to local communities through different State agencies that have discrete requirements and vary in award time.

\section{Importance of Local Presence and Cooperation}

A consistent theme that emerged from discussions with program managers was the value of fostering good communication and relationships with key stakeholders at the local and regional levels.

Numerous agencies maintain local or regional field offices, whose personnel establish and maintain personal relationships with local stakeholders. Field personnel can include Federal employees (for example, USDA Outreach and Public Affairs Division staff and NOAA Office for Coastal Management regional staff), representatives chosen and employed by local constituencies (for example, Tribal Resilience Leaders who serve as liaisons between tribes and the BIA), and teams supported by States to prepare for and 
coordinate disaster response (for example, the "Silver Jackets" program that coordinates with agencies such as USACE and FEMA).

In addition to working directly with individual stakeholders, relationships with local and regional officials are often important in helping potential applicants access a program. Many communities do not have sufficient in-house expertise to develop a loan or grant application to a Federal agency, and benefit from the guidance of local, non-Federal representatives who are familiar both with the agency and have an understanding of local issues. In addition, individual property or business owners who may be reluctant to share personal or financial information with remote representatives of a Federal agency are often more comfortable working with familiar local officials who can serve as a bridge to access Federal resources. Additionally, national associations and technical assistance providers (NADO, IEDC, etc.) also conduct outreach and provide guidance with support from federal agencies like EDA and FEMA and amplify the importance and availability of resilience programs.

\section{Mechanisms for Interagency Coordination}

An important interface for coordinating community resilience efforts is the Mitigation Framework Leadership Group (MitFLG), a national coordinating structure established under PPD-8 to coordinate mitigation efforts across the Federal Government. ${ }^{13}$ The MitFLG focuses on integrating Federal efforts to deliver the core capabilities in the National Mitigation Framework and also assesses the effectiveness of mitigation capabilities as they are developed and deployed across the Nation.

Several agencies and departments have memorandums of understanding (MOUs) promoting bilateral cooperation and coordination in particular sectors pertaining to resilience. The USDA Forest Service, FEMA's Hazards Mitigation Program, and the Department of the Interior (DOI) Office of Wildland Fires are reportedly in the process of preparing an MOU to formalize their cooperation in preventing and responding to wildfires. EDA has an MOU with HUD to encourage integrated planning and has ongoing collaboration with FEMA, EPA, DOT and USDA to support initiatives for community economic resilience and sustainability. FEMA and EPA have an MOU to streamline coordination with the SRFs and enable rapid funding for essential infrastructure projects ${ }^{14}$. Additionally, national associations and technical assistance providers (NADO, IEDC, etc.), with support from federal agencies like EDA and FEMA, also conduct outreach, provide guidance and amplify the importance and availability of resilience programs.

\footnotetext{
13 For more on the National Mitigation Framework, see https://www.fema.gov/national-mitigationframework

14 https://www.epa.gov/sites/production/files/2019-05/documents/mou_between_epa_and_dhs.pdf
} 
Beyond top-down interagency coordination efforts, multiple program managers indicated that some of the most effective collaboration among agencies takes place at joint Federal field offices during and immediately following disasters. Multiple agencies (DHS, HUD, EDA, NOAA) send representatives to the sites of disasters to organize recovery efforts. Their proximity to communities and individuals who need help as well as to each other often provides opportunities for representatives from one agency to direct applicants for support to other agencies for additional aid or to coordinate what they can offer among multiple agencies.

\section{F. Principal Program Findings}

The database of Federal resilience programs combined with discussions with program managers yielded a great deal of information about the variety and nature of resources available to communities, but five principal findings relevant to the objectives of this study stood out.

$(P-1)$ Of the 43 identified programs, 7 are available exclusively prior to a disruption event and 22 are accessible exclusively after a disaster.

(P-2) Only 5 identified programs specifically provide support for planning in contrast to 22 for mitigation, 18 for response, and 20 for recovery.

These two findings suggest that Federal programs as a whole are more reactive than proactive, focusing more on what happens after a disruption event and less on preparing for events in the future.

(P-3) Programs in the database addressing different aspects of resilience emphasize different requirements.

Recovery programs tend to have financial, compliance, planning, and threshold requirements; mitigation programs tend to have financial, compliance, and planning requirements; and response programs tend to have financial and threshold requirements. These findings suggest that access to Federal resources depends on meeting different sets of requirements for support of planning, mitigation, response, or recovery.

(P-4) Planning, response, and recovery programs are not generally tied to specific hazards, whereas mitigation programs are generally tied to specific hazards.

If communities are interested in mitigation, the resources available to them may depend on the hazard they face.

(P-5) Based on conversations with Federal program managers, about half of the agencies included in the database define resilience in a manner consistent with PPD-8/PPD-21, whereas the rest use alternative definitions or have no formal definition. 
The observation that about half of the agencies identified in this study do not use the definition of resilience established in PPD-8/PPD-12 suggests that their support for community resilience is refracted through the lens of their particular missions. 


\section{Community Resilience Tools}

\section{A. Objectives}

The overarching objective of this part of the study is to produce a systematic compilation of tools available to communities applying for support from Federal resilience programs. In this case, tools refer to software, databases, guidebooks, checklists, mapping applications, and any other resource that a community does not have to apply for to evaluate or enhance its resilience. The resulting database (Appendix F) provides a basis for evaluating the resources communities can access to fulfill Federal resilience program requirements and help them take advantage of available opportunities for fostering and strengthening their resilience.

\section{B. Assembling the Database of Resilience Tools}

The database of community resilience tools was derived from an initial list provided by NIST and included tools reported in NIST Special Publication 1240 (McAllister et al. 2019). Next, the web pages of all Federal programs identified in the programs database (Figure 2) were checked for tools as well as the websites of their host departments and agencies. Instructions for applying to Federal programs were not counted as tools, but federally provided resources that allowed applicants to carry out self-evaluations of factors contributing to resilience (state of planning, finance, infrastructure, etc.) were included, whether they targeted a specific program or not. In addition, an internet search for additional tools specifically referring to "resilience" was carried out using the search terms "community resilience tools," "federal community resilience tools," and "resilience tool." It is noted that the tools identified using this criteria may not have identified other available tools.

\section{Characterizing Resilience Tools}

In order to compare and contrast the wide variety of resilience tools available to communities, all were characterized based on four major factors (Figure 5):

1. the type of tool;

2. the tool provider;

3. the primary focus of the tool; and

4. the $\operatorname{hazard}(\boldsymbol{s})$ the tool targeted. 
As with the analysis of programs, the classification of tools was based on factors that emerged from examination of the database and were deemed to provide some degree of insight into the nature of include tools rather than being defined a priori. The resulting framework provides a means of sorting and organizing the tools identified in this work but should not be considered universally applicable.

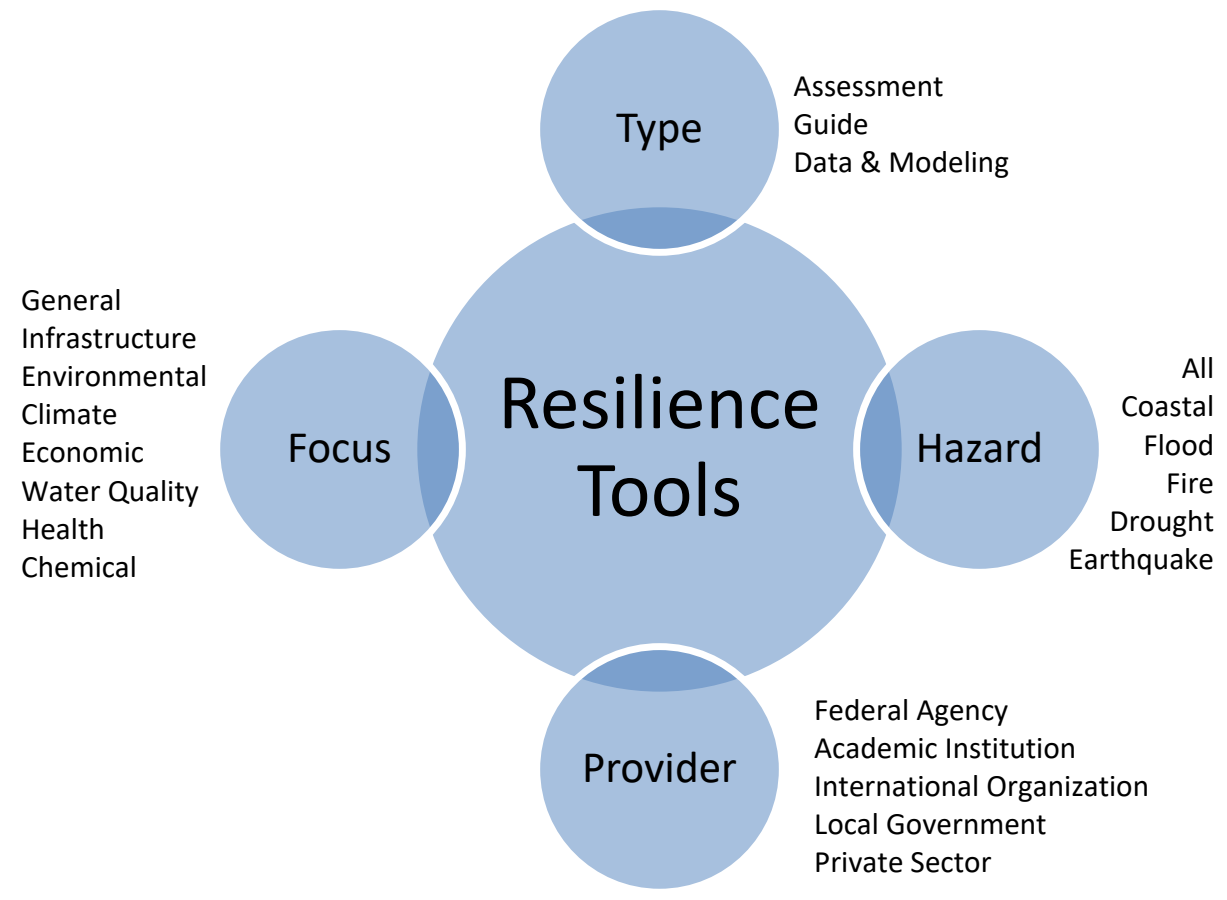

Figure 5. Major Factors Used to Characterize Tools Available for Communities to Strengthen Their Resilience

\section{Tool Types}

The nature of tools was found to be quite variable, ranging from interactive web applications to checklist documents to spreadsheet macros. Tools were grouped into three broad categories: guides, assessments, and data \& modeling (Table 8).

\section{Table 8. Types of Tools}

Guides: Any resource that presents a general methodology or framework for addressing aspects of resilience, including how to develop plans, projects, and strategies.

Assessments: Any tool that uses information specific to a community to evaluate any component(s) of its resilience. Assessments include checklists and scorecards; they can be documents or interactive digital tools.

Data \& Modeling: Any tool that provides access to data necessary for modeling and assessment or that simulates a hazard scenario. Data and models may be integrated. These tools include both online web interfaces and downloadable data files and software. 


\section{Tool Providers}

Variation in the scope of the tools offered by different types of providers can reflect contrasts in the nature of their missions, how they relate to communities, and their resilience priorities. Tools are offered by a variety of organizations and entities ranging from for-profit corporations to Federal agencies to academic institutions (Table 9).

Table 9. Types of Providers

Federal Agency: Provider is a Federal agency or office. These tools are freely available.

Private Sector: Provider is a private-sector entity; can be for-profit or non-profit. Tools provided by non-profit entities are generally free, but some provided by for-profit entities may require purchase.

Local Government: Provider is a public agency or office serving a specific community or region.

Academic Institution: Provider is based at an academic institution.

International Organization: Provider is an international entity, possibly with support from more than one government.

\section{Hazards}

Some tools address specific natural hazards: coastal, flood, fire, drought, and earthquake. All of these hazards except earthquakes are also served by one or more Federal programs (Figure 2). Tools that address preparation for, response to, or recovery from any natural hazard were assigned to the all category; tools that did not address a hazard (for example, tools for evaluation of infrastructure security or assessment of community interconnectedness) were not assigned to any hazard category.

\section{Tool Focus}

In order to refine the categorization of tools, each was assigned a primary focus (Table 10). To the degree possible, these were chosen to correspond to the focus areas identified for Federal programs (Table 4): infrastructure, economy, environment, and health were found to apply to both programs and tools. However, numerous tools were also identified with focus areas that were not observed in the programs database, namely, climate, water, and hazardous chemicals.

In addition, a number of tools were found that did not center on a single component of resilience, but instead focused on fostering community resilience by integrating more than one focus area. These non-specific tools were categorized as having a general resilience focus and serve to bridge two or more resilience concerns, including hazards, infrastructure, governance, economic well-being, land use, and social institutions. The general focus area also captured a handful of data and modeling tools that provide information relevant to resilience but that serve other uses that are not associated with 
resilience (for example, digital elevation data are widely used in non-resilience applications).

Table 10. Primary Focus of Tools

General: Focus on resilience as a property of a community or system emerging from the intersection of disparate factors and concerns that a community must integrate to foster resilience, including hazards, infrastructure, social institutions, governance, economic wellbeing, land use, etc. In addition, in the case of data and modeling tools, the general focus area also includes those tools that provide fundamental information that applies more broadly than resilience analysis.

Infrastructure: Focus on building, protecting or improving machinery and facilities (for example, buildings, roads, water, sewage, power) that enable the vital functions of a community's governance, public health, and economy.

Environmental: Management and restoration of natural resources contributing to the resilience of a community.

Climate: Focus is to help users evaluate how their circumstances will change due to climate impacts on social, economic, environmental, and physical systems. Climate impacts need not be related to natural disasters or particular hazards.

Economic: Fiscal, financial, and commercial activities within a community, including public expenditure, individual income and employment, and business activity.

Water Quality: Water sources, treatment, distribution, collection, and quality.

Health: Help the residents of a community prepare for, cope with, and recover from the mental, physical, and other stresses experienced in the aftermath of a natural disaster or other disruption.

Chemical: Hazardous chemicals.

\section{Tools Database Results}

\section{Distribution of Tools Among Factors}

The database includes 128 tools that could be used by communities to analyze or otherwise improve their resilience. The distribution of each of the three types of tools among the major factors is displayed in Figures 6, 7, and 8.

Of the different tool types (Figure 9A), just over half consist of data and modeling resources (67), a quarter consist of assessment tools (32), and the rest are guides (22). The two largest providers of tools are Federal agencies (61) and private entities (40) with the other three provider types accounting for just 16\% of the total (Figure 9B). 91 tools address natural hazards, with more than half applicable to all types of hazards (Figure 9C). Of those that target a specific hazard, the majority address coastal hazards. 
Focus

Hazard

\section{Data \& Modeling Tools}

\section{Federal Agencies}
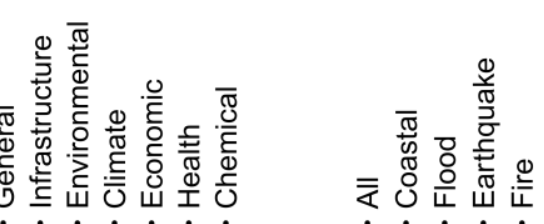

Marine Minerals Information System ( BOEM) Hazard Mitigation Cost Effectiveness Tool ( DOT - FTA ) Sensitivity Matrix ( DOT - FHWA ) CAMEO Software Suite ( EPA, NOAA ORR ) EnviroAtlas ( EPA, Forest Trends, Landscope America, Natureserve, USDA, USGS ) Global Change Explorer ( EPA ) Data Visualization: Summary of Disaster Declarations and Grants ( FEMA ) FEMA Flood Insurace Rate Maps (FIRMs) ( FEMA) FEMA Hazus ( FEMA ) Resilience Analysis and Planning Tool (RAPT) ( FEMA ) Riverine Flood Innundation Maps ( FEMA, NOAA NWS, NOAA OCM, USACE, USGS ) United States Interagency Elevation Inventory ( FEMA, National Parks Service, NOAA OCM, USACE, USDA, USGS ) NIST Economic Decision Guide Software (EDGe\$) ( NIST ) Beach Nourishment Viewer ( NOAA Program for the Study of Developed Shoreline ) C-CAP Land Cover Analysis ( NOAA OCM ) Coastal County Snapshots ( NOAA OCM ) CoastalFlood Exposure Mapper ( NOAA OCM ) Digital Coast (NOAA OCM ) Environmental Response Management Application ( NOAA ORR ) Great Lakes Water Level Dashboard ( NOAA Great Lakes Environmental Research Lab ) NOAA Hurricane Storm Surge Maps ( NOAA NHC ) NOAA National Water Model ( NOAA OWP ) NOAA Sea Level Rise Viewer ( NOAA OCM ) OpenNSPECT ( NOAA OCM ) SLOSH Model (NOAA) Sediment Volume Change Mapper ( NOAA, USACE, USGS ) Tsunami Aware ( NOAA OCM, Hawaii Emergency Management Agency )

U.S. Climate Resilience Toolkit ( NOAA ) Wave Exposure Model ( NOAA NCCOS ) SimCenter ( NSF Natural Hazards Engineering Research Infrastructure Program ) Hydrologic Engineering Center's River Analysis System (HEC-RAS) ( USACE ) USACE Sea-Level Change Curve Calculator ( USACE ) FUSION ( USDA Forest Service Remote Sensing Applications Center ) 3DEP (3D Elevation Program Products) ( USGS ) Science in the Great Lakes Mapper ( USGS ) USGS Earthquake Probability Maps ( USGS ) Tribal Nations Toolkit (climate.gov - US Climate Resilience Toolkit)

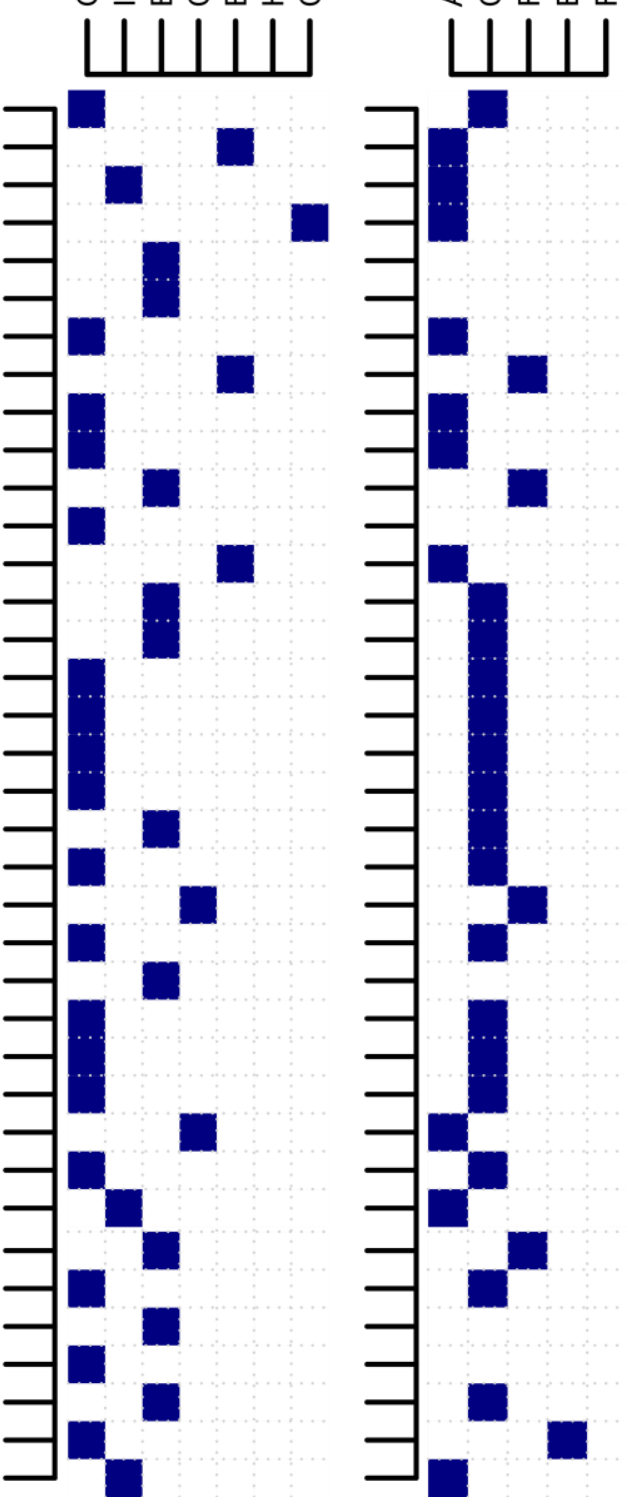

Figure 6. Distribution of Data \& Modeling Tools Included in this Study 


\section{Data \& Modeling Tools}

\section{Academic Institutions}

City-Scale Modeling ( Berkeley Engineering) Interdependent Networked Community Resilience Modeling Environment ( Center for Risk-Based Community Resilience Planning, CSU ) MAEViz, Mid-America Earthquake Center Seismic Loss Assessment System ( MAE Center, University of Illinois )

Marxan with Zones (Univesity of Queensland Australia ) OpenSees ( Pacific Earthquake Engineering Research Center) Spatial Hazard Events and Losses Database for US (SHELDUS) ( Arizona State University)

\section{International Organizations}

\section{Private-Sector Providers}

WUI Maps ( Silvis Lab, University of Wisconsin-Madison )

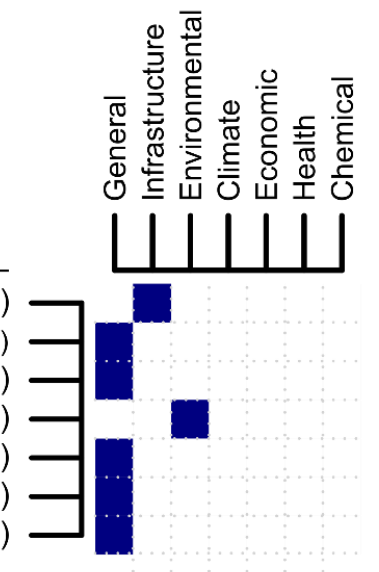

Open Data for Resilience Index ( GFDRR ) ThinkHazard! ( GFDRR)

American Planning Association - Community Resilience Scenario Planning Model ( American Planning Association CAESAR (Cascading Effect Simulation in Urban Areas to Access and Increase Resilience) ( Frainhofer EMI) CIRCLE (Critical Infrastructures Relations and Consequences for Life and Environment) (Deltares ) CoastalResilience Mapper ( TNC ) Elephant Builder ( Bellweather Collaboratory)

Gulf TREE ( Gulf of Mexico COP, GOM Alliance, Northern GOM Sentinel Site Cooperative ) Integrated Valuation of Environmental Services and Tradeoffs (InVEST) ( Natural Capital Project) Kaiser Permanente Hazard Vulnerability Analsis (HVA) (California Hospital Assosiation ) LEO Network ( Alaska Native Tribal Health Consortium ) National Beach Nourishment Database ( ASBPA ) NatureServe Vista ( NatureServe ) OASIS Loss Modeling Framework ( Oasis ) Our Coast, Our Future - Flood Map ( Point Blue ) OurWater ( The Resilience Shift ) Partnership for Resilience and Preparedness Data (World Research Institute ) Resilience Atlas (Conservation International) Resilience.io (Ecological Sequestration Trust) Surging Seas (Climate Central) The Standard for Sustainable and Resilience Infrastructure (SuRe) ( Global Infrastructure Basel)

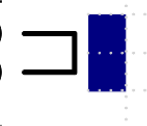
$\sqsupset$

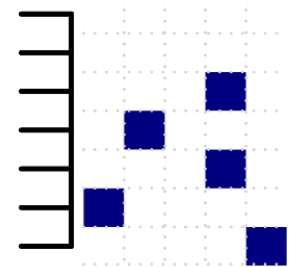
XDIGlobe ( XDI Cross Dependency Initiative )
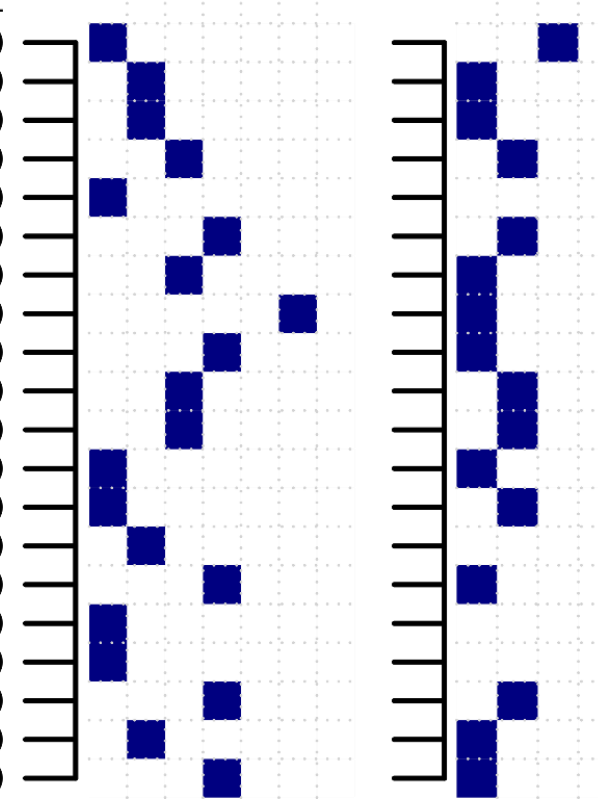

Figure 6 (continued). Distribution of Data \& Modeling Tools Included in this Study 


\section{Assessment Tools}

Federal Agencies

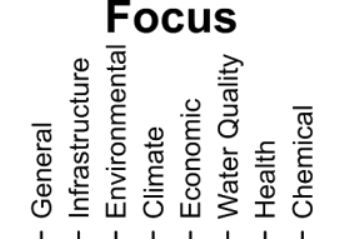

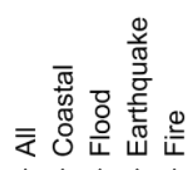

Guide to Assessing Criticality in Transportation Adaptation Planning (DOT - FHWA ) Vulnerability Assessment Scoring Tool ( DOT - FHWA )

EPA Flood Resilience Checklist [EPA 2014] ( EPA ) Continuity Assessment Tool ( FEMA) NFIP Community Rating System Coordinator's Manual ( FEMA ) National Risk Index ( FEMA ) Preparedness Toolkit ( FEMA) Threat and Hazard Identification and Risk Assessment (THIRA) ( FEMA) Wildland Urban Interface (WUI) Toolkit ( FEMA) Academic Institutions

Community Resilience Economic Decision Guide for Buildings and Infrastructure Systems ( NIST) -

CoastalResilience Index: A Community Self-Assessment (Mississippi-Alabama Sea Grant Consortium ) Communities Advancing Resilience Toolkit (University of Oklahoma Terrorism and Disaster Center ) Envision ( ISI and Zofnass Program for Sustainable Infrastructure (Harvard) )

Plan Integration for Resilience Scorecard ( Texas A\&M-DHS Coastal Resilience Center of Excellence ) International Organizations

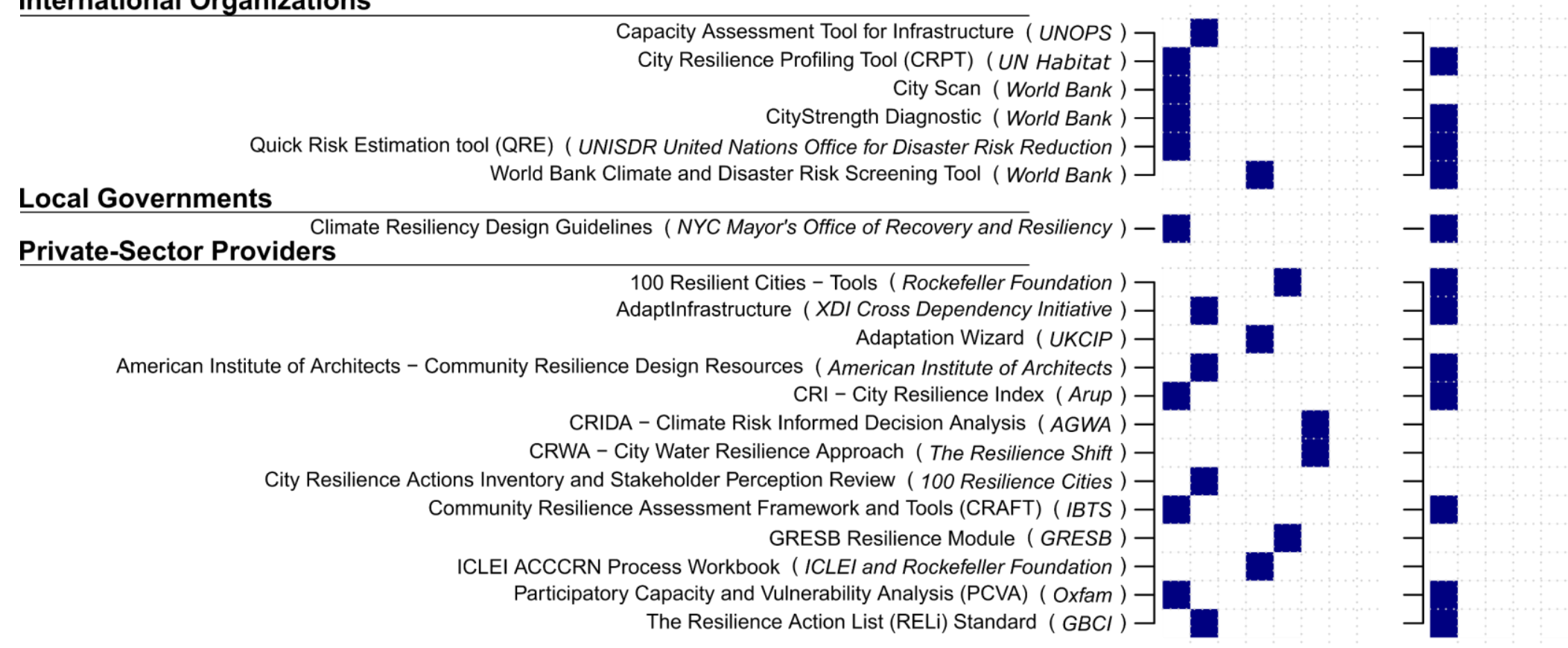

Figure 7. Distribution of Assessment Tools Included in this Study 


\section{Guides}

\section{Federal Agencies}

Highways in the Coastal Environment: Assessing Extreme Events (DOT - FHWA) Highways in the River Environment: Floodplains, Extreme Events, Risk, and Resilience (DOT - FHWA ) Vulnerability Assessment and Adaptation Framework ( DOT - FHWA ) Comprehensive Economic Development Strategy ( $E D A$ ) EPA Regional Resilience Toolkit [EPA 2019] ( EPA ) Community Recovery Management Toolkit ( FEMA ) Effective Coordination of Recovery Resources ( FEMA ) FEMA Plan Integration: Linking Local Planning Efforts ( FEMA ) FEMA STAPLEE Criteria Worksheet ( FEMA ) -

Listing of Disaster Recovery Funding Resources ( FEMA ) Long Term Community Recovery Planning Process: A Self-Help Guide ( FEMA ) Mistakes Leading to Audits and Potential Loss of FEMA Public Assistance Funding ( FEMA ) National Disaster Recovery Framework (NDRF) ( FEMA ) Pre-Disaster Recovery Guide for Local Governments ( FEMA ) Pre-Disaster Recovery Planning Guide for State Governments ( FEMA ) HUD Community Resilience Planning Resources ( HUD ) Community Resilience Planning Guide ( NIST ) Coastal Resilience Indicators and Rating Systems ( NOAA OCM ) Community Facilities Infrastructure Toolkit ( USDA ) -

\section{Academic Institutions}

Crosswalking Between Gray and Green Infrastructure for Budget Officers -

\section{Private-Sector Providers} ( UNC Environmental Finance Center)

Community Resilience Building ( The Nature Conservancy )Ecoadapt Climate Adaptation Knowledge Exchange ( Ecoadapt ) HAZUR ( OPTICITS ) RAND Community Resilience Toolkits ( RAND ) Resilience Value Realization (RVR) ( Marcela Ruibal ) Resilience-based Earthquake Design Initiative (REDi) ( Arup )-
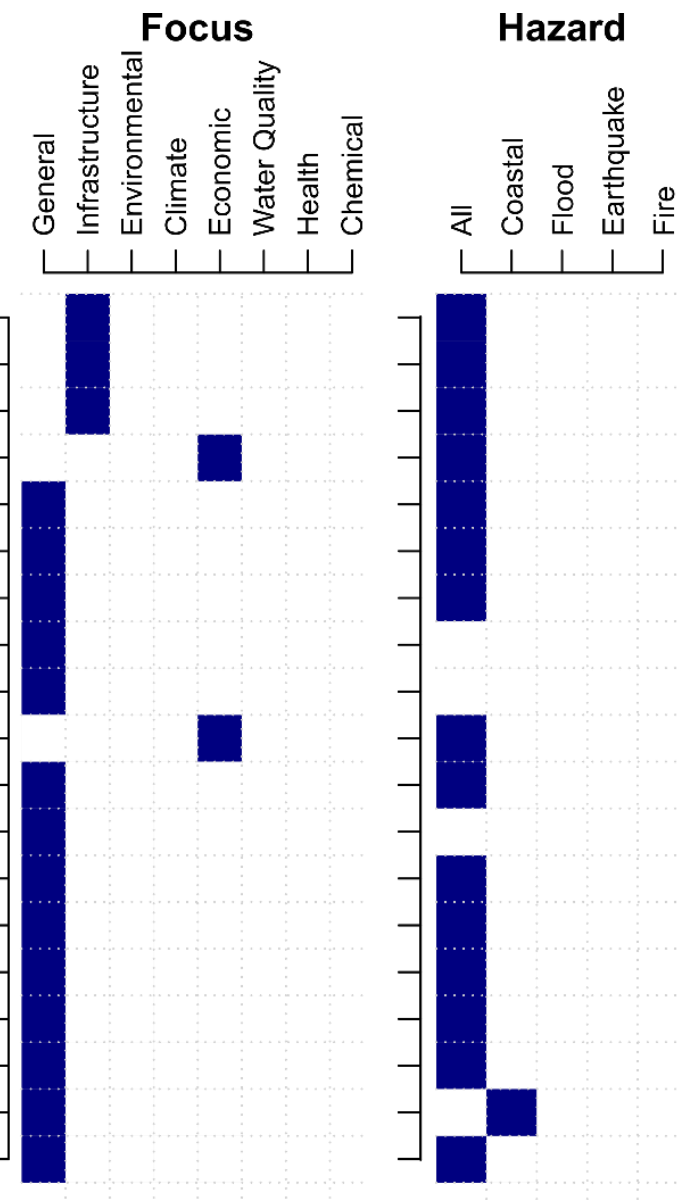

CRAFT - Climate Risk and Adaptation Framework and Taxonomy ( Arup )

HAZUR ( OPTICITS )
RAND Community Resilience Toolkits ( RAND )
Resilience Value Realization (RVR) (Marcela Ruibal)
Resilience-based Earthquake Design Initiative (REDi) (Arup)

Figure 8. Distribution of Guide Tools Included in This Study

Just over half of the tools (62) in the database have general community resilience as their primary focus (Figure 9D). Nineteen tools focus on infrastructure and almost equal numbers focus on environmental and climate considerations (15 and 14, respectively). Comparing the focus areas of tools with the focus areas of programs (Table 4), two-thirds of the tools (79) had focus areas (general, climate, water quality, and chemical) that do not occur as program focus areas. 
Principal Finding T-1. Most resilience tools do not target specific Federal programs or requirements.

Principal Finding T-2. Approximately half of the tools identified in the database (65 of 128) have a general resilience focus.

Principal Finding T-3. Of the tools with focus areas more specific than the general category, 45 address focus areas also targeted by Federal programs (infrastructure, environment, economy, health) and 16 address focus areas not targeted by Federal programs (water quality, climate, chemical).
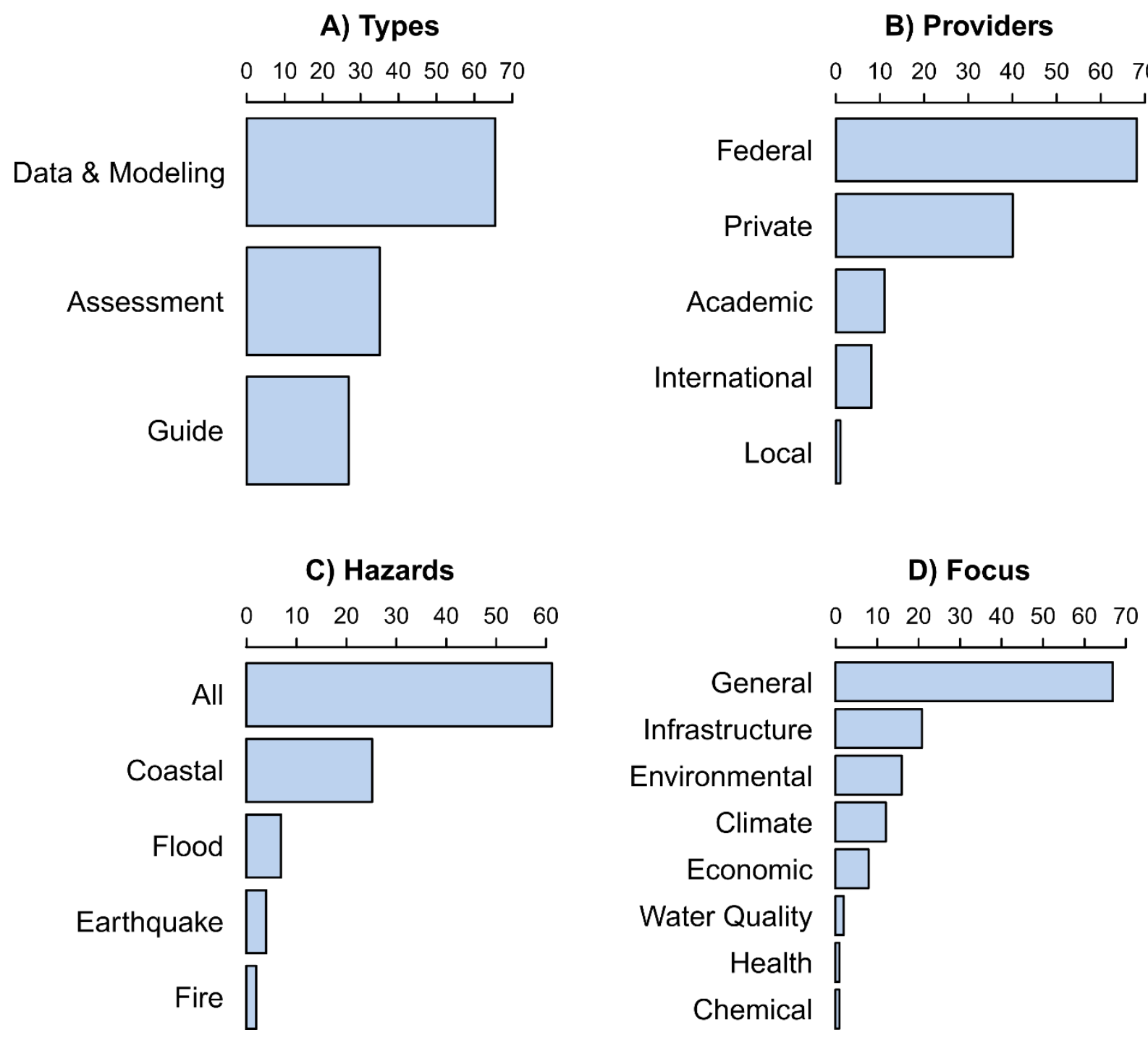

Each bar indicates the number of tools falling into a category; each tool falls in only one category per factor.

Figure 9. Distributions of Resilience Tool Characteristics 


\section{Interactions Between Tool Factors}

The database provides the means to examine interactions between factors characterizing tools (Figure 10). Because the relationships reported here are purely descriptive, statistical significance was not evaluated and no inferences about possible relationships should be extrapolated beyond the tools considered in this report.

In the comparison between tool focus and tool type (Figure 10A), tools with an environmental and climate focus have a smaller proportion of assessment and guide tools than tools focusing on general resilience. Environmental and climate tools also tend to focus on coastal hazards to a greater degree than infrastructure tools and general resilience tools (Figure 10B). And in terms of providers of tools versus focus, Federal agencies focus heavily on general resilience tools, whereas private sector providers have a proportionately higher emphasis on infrastructure and climate (Figure 10C).

Data and modeling tools tend to target either all hazards or coastal hazards (Figure 10D). In terms of the types of tools offered by different providers, both the Federal and private sectors offer data and modeling resources, but the private sector appears to favor assessment tools and Federal agencies appear to favor guides (Figure 10E). The comparison between hazards and providers shows the dominance of Federal and private sector providers offering tools focused on all and coastal hazards (Figure 10F), consistent with the overall distribution of tools within factors seen in Figure 9.

Principal Finding T-4. Both Federal agencies and the private sector provide numerous data and modeling tools (38 and 20, respectively). However, Federal agencies offer more guide tools (14) than assessment tools (9), whereas the private sector offers more assessment tools (13) than guide tools (7). 
A) focus v. type

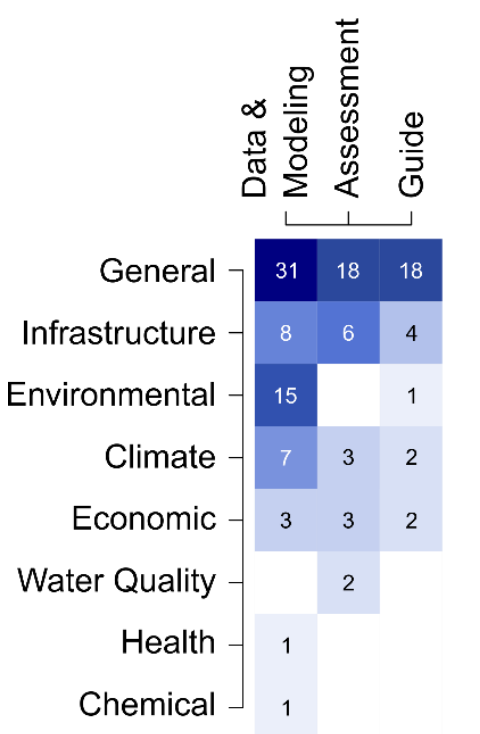

B) focus v. hazard

C) focus v. provider

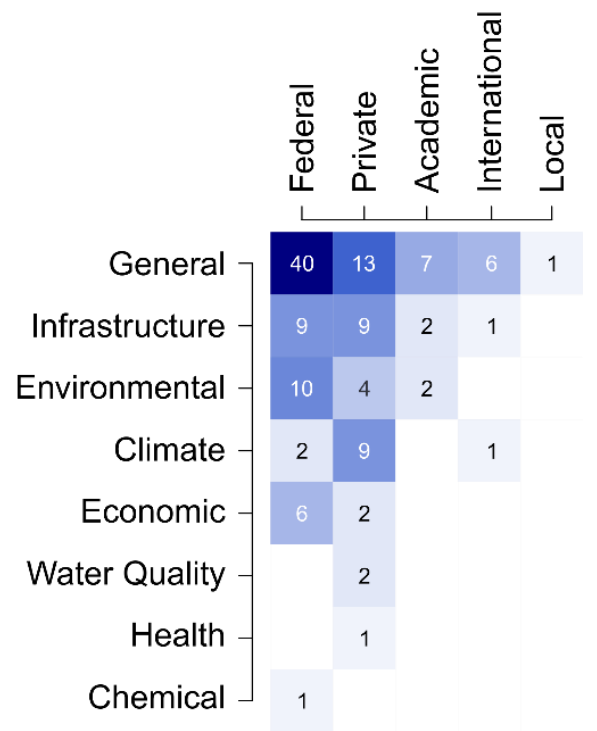

E) type v. provider

D) type v. hazard
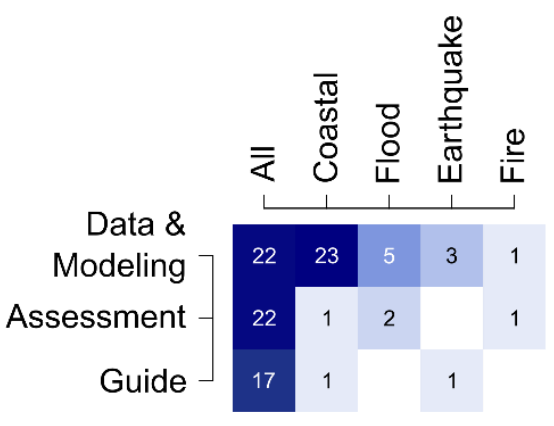

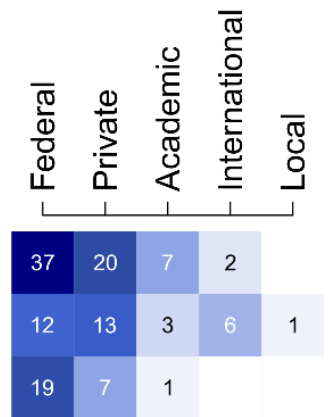

F) hazard v. provider

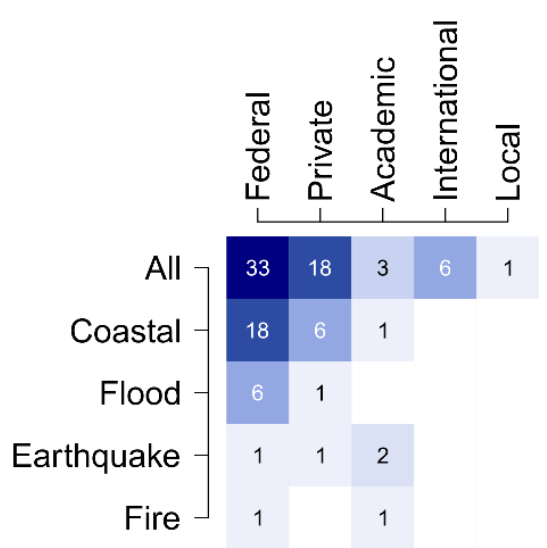

Each cell indicates the number of tools occupying the intersection of two categories.

Figure 10. Two-way Tables Comparing Resilience Tool Factors 


\section{E. Principal Tool Findings}

The database of resilience tools revealed a wide variety of data, models, taxonomies, guides, and checklists available to communities seeking to better understand or evaluate the state of their resilience. In exploring the database of tools, several observations and principal findings emerged with implications for the objectives of this study.

(T-1) Most resilience tools do not target specific Federal programs or requirements.

For the most part, resilience tools, even those provided by Federal agencies, are not deliberately aligned to specific Federal programs, and program requirements do not direct applicants to use specific tools.

(T-2) Approximately half of the tools identified in the database (65 of 128) have a general resilience focus.

The large number of general tools suggests an appreciation among providers, both Federal and non-Federal, that fostering community resilience requires not just supporting individual projects and activities but ensuring that they are integrated and mutually supportive. General tools are those that provide the information and guidance to help communities advance resilience holistically.

(T-3) Of the tools with focus areas more specific than the general category, 45 address focus areas also targeted by Federal programs (infrastructure, environment, economy, health) and 16 address focus areas not targeted by Federal programs (water quality, climate, chemical).

Only about a third of the tools identified in this study address resilience focus areas that are also addressed by Federal programs included in this study.

(T-4) Both Federal agencies and the private sector provide numerous data and modeling tools (37 and 20, respectively). However, Federal agencies offer more guide tools (18) than assessment tools (10), whereas the private sector offers more assessment tools (13) than guide tools (7).

The private sector emphasizes different types of tools from those provided by Federal agencies: both distribute data and modeling tools designed to deliver fundamental information needed to address aspects of community resilience, but Federal agencies tend to issue guidance documents providing strategies for framing resilience, whereas the private sector tends to provide assessments aimed at helping communities evaluate their circumstances or the state of their resilience. 


\section{Discussion and Future Research}

\section{A. Expanding the Scope of Resilience}

One of the challenges in characterizing resilience programs and tools encountered in the course of this study is a degree of ambiguity in the way the term "resilience" is understood by various stakeholders. The definition used in this study - "the ability to prepare for and adapt to changing conditions and withstand and recover rapidly from disruptions" - is based on two Presidential Policy Directives (PPD-8 and PPD-21) that both put a strong emphasis on national preparedness and protection, which in turn has been incorporated into the National Planning Frameworks. ${ }^{15}$

However, in a systematic review of how the term "community resilience" is used in the published literature, Patel et al. (2017) found no evidence for a common, agreed definition of the term. Instead, they found that published discussions of community resilience consistently incorporated a wider array of recurring elements than is emphasized in the definition in this study, including local knowledge, networks and relationships, communication, health, governance and leadership, and economic investment.

Discussions with Federal program managers revealed that a number of programs that see resilience as part of their mission do not use the PPD-8/PPD-21 definition or use no formal definition at all (Table 6). This suggests that although their missions clearly touch on resilience, their activities are not strictly aligned with or go beyond the narrow definition used in this study.

In addition to programs included in the database that do not adhere to the PPD-8/PPD21 definition of resilience, a number of programs whose activities focus on sustainability, adaptation, and efficiency were not included in the database because they do not explicitly focus on preparation for and recovery from disruptions. An example of such a program is the Department of Energy's Weatherization Assistance Program, which offers assistance to States to help low-income households increase the energy efficiency of their homes. ${ }^{16}$ Although its activities can help reduce the impact of disruptions, it does not specifically target the consequences the hazard events. Its work falls outside a narrow reading of the PPD-8/PPD-21 definition of resilience but well within the broader sense of the term identified by Patel et al. (2017). The number of programs like this one that are not integrated into the National Planning Frameworks but that can offer resources to

\footnotetext{
15 https://www.fema.gov/national-planning-frameworks

16 https://www.energy.gov/eere/wipo/weatherization-assistance-program
} 
communities to enhance their resilience in the face of disruptions was not systematically investigated as part of this study.

The contrast between the broader interpretation of resilience versus the interpretation used in the Federal preparedness context has the potential to lead to missed opportunities. For example, communities seeking support to improve their resilience may overlook agencies or programs that could provide useful resources because such programs fall outside the Federal Mitigation Framework. Future work evaluating the availability and access of Federal resilience resources would benefit from developing a resilience study framework flexible enough to incorporate the full array of relevant programs.

\section{B. Obtaining a Community Perspective}

This study identifies an abundance of resources and tools available to communities but does not provide an assessment of which ones they actually use, their ability to implement those that are available, or whether available tools meet their needs. Addressing these questions requires obtaining data from communities themselves, but communities vary enormously in geographic extent, population size, potential hazards, and administrative capacity, complicating the collection of coherent and consistent information.

The Resilience America Program ${ }^{17}$ of the National Academies of Science, Engineering, and Medicine has approached this problem by selecting a handful of representative communities spanning a range of size, demography, economy, and region and holding a workshop to identify the challenges they face and strategies they use in their particular circumstances (NASEM 2018). A similar approach could be adopted specifically addressing needs and tools. Although information gathered using such a strategy would be thoroughly contextualized, because the details of the representative communities would be well known, this approach could potentially overemphasize issues particular to the participating communities.

Alternatively, a pool of communities could be generated based on recipients of support from Federal programs. Such a list would ensure that participating communities know about a program and can relate their experience applying to it, including how they may have used various tools to do so. In addition, data on the number of applicants and recipients could at least partially address whether programs are able to meet needs. Starting with such a base of communities that received support from a program, it may also be possible to identify similar communities that did not apply or whose applications were unsuccessful, which could provide insight into the obstacles faced by non-recipients. Although such an approach would generate an unambiguously relevant pool, it would also

\footnotetext{
${ }^{17}$ https://www.nationalacademies.org/resilient-america
} 
limit information to the particular focus areas, aspects of resilience, or hazards served by the program.

Despite these challenges in identifying a representative sample of communities, obtaining the perspectives of communities would provide valuable insights to reduce the technical and administrative barriers they face in resilience planning and implementation. 


\section{Appendix A. Discussion Protocol for Federal Program Managers}

\section{$\underline{\text { Interview Protocol for Federal Community Resilience Program Managers }}$}

Thank you for taking the time to speak with us today. My name is [] and I work at IDA Science and Technology Policy Institute (STPI). STPI has been asked by the National Institute of Standards and Technology (NIST) to research Federal programs that provide funds or resources to promote community resilience to natural hazards. As part of this effort, STPI is conducting interviews with Federal program managers like you to understand the goals of these and the challenges they face. This information will be used develop an understanding of what programs and resources are currently available to communities and where gaps may exist.

The information in this interview will be used to discuss agency resilience programs individually as well as in aggregate across the Federal enterprise. Information you provide will not be attributed to you personally, but it may be attributed to your agency or your agency's programs in any summaries or results prepared from these interviews. Before we begin, can we have your permission to record this interview to ensure we capture the information you provide accurately? Recordings will be deleted once we have finished our notes.

We sent you a list of programs we have identified for your agency/organization ahead of this call. The Federal programs included in the e-mail you received were identified through a literature review that used grants.gov and other summary reports of community resilience grant programs to identify current Federal efforts. For the purposes of this task, resilience was defined as "the ability to prepare for anticipated hazards, adapt to changing conditions, and withstand and recover rapidly from disruptions" as described on the NIST Community Resilience website. We have also attempted to characterize these programs based on their focus on resilience to hazards and type of assistance provided based on publicly available information found online.

To your knowledge:

- Do we have the programs within the agency identified correctly?

- Are there omissions that we should be aware of? 
Program Goals and Resilience Measures

- Do all of your programs have similar goals? Do you think it would be helpful to discuss them as a group or separately?

- Tell us about the goals of your program(s).

- Who/what are the target stakeholders for the funding program(s)?

- How does your agency define "resilience" for your program(s)? How does your agency define "sustainability"?

- How do you measure "resilience" for your program(s)?

Communication \& Dissemination

- How is your program(s) promoted and communicated?

- Where do communities acquire the necessary information/data about your program(s)?

- How much flexibility do communities have in terms of where they get the data and information necessary to apply for funding? Are there required authoritative sources or suggested resources you make available?

Challenges \& Successes

- What are the primary challenges you face with your program(s)? How do you overcome them?

- What are the lessons learned you would apply to future programs in this area?

- Are there specific services or resources, either from your agency or elsewhere, that are not currently available but you think would help communities access your program? If so, please describe them.

Other

- Are there any other Federal programs related to community-scale resilience that we should be aware of or focus on? If so, is there a POC you can recommend we contact?

- Is there anything else you would like to share with us about your community resilience portfolio?

There is also some information about specific requirements and other details for your program(s) that we could not find.

- After this call, would your agency be willing to fill in the missing information for your programs and send it back to us?

- Who is the most appropriate contact for details about these programs? 
Email for Federal program managers:

Dear (NAME):

The National Institute of Standards and Technology (NIST)'s Community Resilience Group has asked the Science and Technology Policy Institute (STPI) to examine the types of information and data that communities have access to that aid their resilience planning efforts. The project aims to: (1) understand the data and information requirements for communities undertaking resilience planning, (2) characterize the set of Federally-supported programs and tools that are used by communities, and (3) understand how well currently available tools and programs are meeting the needs of user communities.

As a first step, we would like to speak with you about your agency's Federal programs that provide funding support or technical assistance to communities who are undergoing resilience planning. These could be programs that are looking to develop resilience plans, are aiming to implement disaster mitigation measures, are implementing recovery measures, or are otherwise seeking to support community resilience efforts. We have identified the following programs at your agency thus far in our research and would like to discuss the goals, challenges, and successes you've seen with these programs:

[insert agency program list]

Do you have time for a 1-hour conversation within the next two weeks (by May ${ }^{\text {rd }}$ ) to discuss your program(s) with us? [Insert available dates / times]

Your help will ensure that existing Federal programs are accurately and correctly summarized in this project and that communities are well served by the array of available Federal resources they may use in their efforts to improve resilience.

Thank you, 


\section{Appendix B. Federal Community Resilience Program Profiles}

\section{Definitions of Variables}

Yellow cells indicate that STPI was unable to find any information and the program manager left the cell blank. If a cell is irrelevant to the program, it will be marked with N/A.

\section{Definitions of Variables}

\section{Variable}

Agency
Name of Program
Link to Program
Description
Resilience to Natural Disasters is a
Program Priority
Type of Resilience
Total Funds Available
Funding Limitations Per Application
Cost Share Requirements
Application Deadlines
Length of Benefit
Eligible Applicants
Eligible Subapplicants
Eligible Recipients

Low-Income, Impoverished Community Status Prioritized

Hazards Included

Funding for Pre-disaster Activities Funding for Post-disaster Activities Disaster Declaration Required

Unusual Circumstances Accepted

Type of Facility or Land Funded

Other Assistance Provided Project Types
Federal sponsor of program

\section{Description}

Name of program

URL to home page of the program on agency's website

Brief description of program from agency's website

One of the program goals is to enhance the resilience of infrastructure or a community to a natural disaster (Y/N)

Mitigation, Response, Recovery, and/or Planning (not mutually exclusive)

Estimate of funding allocation to program

Maximum funding per application

Percentage of costs Federal Government covers

Time requirements to submit an application

How long the assistance will last, e.g., loan terms

Entities eligible to directly apply for funding

Entities that can apply with sponsorship from another entity

Entities that will benefit from funding. Applicant may distribute funding assistance to individuals or smaller groups (i.e., recipients)

Grant program requires a percentage of funds to go to low-income communities or individuals, or prioritizes funding for communities who are unable to meet Federal costshare requirements

The type of hazard, if any, that is the program's focus

Funding available for projects to adapt to future disasters

Funding is released after a disaster has occurred

Funding only available after President or authorized Federal department or agency has issued a Major Disaster Declaration. Authorizing department or agency noted in table. Indicated in table if threat of a disaster is sufficient to authorize a declaration.

Unusual circumstances are sufficient to enable funding, including circumstances that could not have been foreseen or prepared for, and are external to the facility that has been damaged

The type of facility (e.g., public facility, home or business) or land (e.g., floodplain, wetlands, coasts) that funding may be allocated towards

Assistance unrelated to infrastructure or land-use, such as unemployment assistance High-level description of projects funded or assistance provided 


\begin{tabular}{|c|c|}
\hline Demonstrate Work is Cost Effective & Application includes project cost evaluation criteria to inform funding decision ${ }^{18}$ \\
\hline $\begin{array}{l}\text { Demonstrate No Available Help } \\
\text { Found Elsewhere }\end{array}$ & $\begin{array}{l}\text { Applicant must demonstrate that assistance or credit is not available elsewhere (e.g., } \\
\text { apply to SBA first if business owner) }\end{array}$ \\
\hline $\begin{array}{l}\text { Demonstrate Good Financial } \\
\text { History }\end{array}$ & $\begin{array}{l}\text { Applicant must demonstrate credit worthiness, grant management experience, and/or } \\
\text { history of financial performance }\end{array}$ \\
\hline Existing Plan / Strategy Required & $\begin{array}{l}\text { Regional strategies or plans required, such as a hazard mitigation plan (often required by } \\
\text { FEMA) }{ }^{19} \text { or a comprehensive economic development strategy (often required by EDA) }\end{array}$ \\
\hline $\begin{array}{l}\text { Special Requirements or Benefits } \\
\text { for SFHA }\end{array}$ & $\begin{array}{l}\text { Application includes specific requirements associated with Special Flood Hazard Areas } \\
\text { (SFHA) }\end{array}$ \\
\hline $\begin{array}{l}\text { Participate / Good Standing with } \\
\text { NFIP }\end{array}$ & $\begin{array}{l}\text { The National Flood Insurance Program (NFIP) insures property owners, renters, and } \\
\text { businesses, and encourages communities to adopt and enforce floodplain management } \\
\text { regulations; incentives include discounts on insurance for SFHA properties }\end{array}$ \\
\hline Existing Insurance Required & Flood insurance, fire insurance, crop insurance requirements \\
\hline Demonstrate NEPA Compliance & $\begin{array}{l}\text { Applicant must fulfill National Environmental Policy Act (NEPA) requirements (e.g., } \\
\text { demonstrate Environmental Planning and Historic Preservation (EHP) compliance) }\end{array}$ \\
\hline Public Outreach Prioritized & Prioritization based on public outreach, public-private partnerships, and private investment \\
\hline Building Code Adoption Required & Building Codes that must be adopted to receive funding \\
\hline Demonstrate Substantial Damage & Description of the infrastructure or land degree of damage ${ }^{21}$ \\
\hline Other Criteria & Other application requirements not included in specified variables \\
\hline
\end{tabular}

18 Benefit Cost Analysis is a method FEMA uses to determine future benefits of a hazard mitigation project compared to its costs. A project is considered cost-effective if its calculated Benefit-Cost Ratio is greater than 1.0 (44 CFR Part 79).

19 State Hazard Mitigation Plans must meet requirements specified in 44 CFR Part 201 (e.g., risk assessment and mitigation strategy)

20 A Comprehensive Economic Development Strategy must meet requirements in 13 CFR Part 303.7

21 For FEMA ICC coverage, substantial damage is defined as the determination by the community that damage due to flood has equaled or exceeded 50 percent of the value of the building. 


\section{Bureau of Indian Affairs (BIA)}

\section{Tribal Resilience Program}

Link to Program: https://www.bia.gov/bia/ots/tribal-resilience-program

Description of Program: Provides federal-wide resources to Tribes to build capacity and resilience through leadership engagement, delivery of data and tools, training and tribal capacity building. Direct funding supports tribes, tribal consortia, and authorized tribal organizations to build resilience through competitive awards for tribally designed resilience training, adaptation planning, vulnerability assessments, supplemental monitoring, capacity building, and youth engagement

\begin{tabular}{|c|c|c|}
\hline & Name of Program & Tribal Resilience Program \\
\hline \multirow[t]{2}{*}{ Resilience Focus } & $\begin{array}{l}\text { Resilience is a Program } \\
\text { Priority }\end{array}$ & \\
\hline & $\begin{array}{l}\text { Mitigation, Planning, } \\
\text { Response, Recovery }\end{array}$ & Planning \\
\hline \multirow[t]{3}{*}{ Program Funding } & Total Funds Available & $\begin{array}{l}\text { \$15M FY20; Program awarded \$12.7M FY17-18, } \\
\text { \$8.6M FY16 }\end{array}$ \\
\hline & $\begin{array}{l}\text { Funding Limitations Per } \\
\text { Application }\end{array}$ & $\begin{array}{l}\text { Category 1. Trainings and Workshops (maximum: } \\
\$ 150,000) \\
\text { Category 2. Adaptation Planning (maximum: } \\
\$ 150,000) \\
\text { Category 3. Travel Support for Adaptation Planning } \\
\text { (maximum: } \$ 15,000) \\
\text { Category 4. Ocean and Coastal Management } \\
\text { Planning: } \$ 150,000) \\
\text { Category 5. Travel Support - Ocean \& Coastal: } \\
(\$ 15,000) \\
\text { Category 6. Capacity Building: (maximum: } \$ 50,000) \\
\text { There is a limit of one award per category per tribe, } \\
\text { not to exceed two awards per tribe. } \\
\text { Category 7: Relocation, Managed Retreat, and } \\
\text { Protect-in-Place Planning activities for coastal and } \\
\text { riverine communities (maximum: } \$ 150,000\end{array}$ \\
\hline & Cost Share Requirements & $\begin{array}{l}\text { There are no matching requirements, but projects } \\
\text { that include in-kind contributions, funds from the } \\
\text { tribal applicant, or partnerships may score higher in } \\
\text { the ranking process. }\end{array}$ \\
\hline \multirow[t]{2}{*}{ Funding Timing } & Application Deadlines & $\begin{array}{l}\text { The application deadline varies by year. It is not } \\
\text { fixed. }\end{array}$ \\
\hline & Length of Benefit & $\begin{array}{l}2 \text { years with an option for no-cost extension given } \\
\text { extenuating circumstances }\end{array}$ \\
\hline \multirow[t]{4}{*}{$\begin{array}{l}\text { Targeted } \\
\text { Applicants and } \\
\text { Recipients }\end{array}$} & Eligible Applicants & $\begin{array}{l}\text { Federally recognized Tribes and Tribal } \\
\text { Organizations and Tribal Colleges that support } \\
\text { these Tribes }\end{array}$ \\
\hline & Eligible Subapplicants & $\mathrm{N} / \mathrm{A}$ \\
\hline & Eligible Recipients & Tribes, Tribal Organizations, and Tribal Colleges \\
\hline & $\begin{array}{l}\text { Low-Income, Impoverished } \\
\text { Community Status } \\
\text { Prioritized }\end{array}$ & \\
\hline $\begin{array}{l}\text { Hazard } \\
\text { Categorization }\end{array}$ & Hazards Included & $\begin{array}{l}\text { Not hazard-focused. Can support planning for } \\
\text { hazards related to climate impacts. }\end{array}$ \\
\hline
\end{tabular}




\begin{tabular}{|c|c|c|}
\hline & $\begin{array}{l}\text { Funding for Pre-disaster } \\
\text { Activities }\end{array}$ & \\
\hline & $\begin{array}{l}\text { Funding for Post-disaster } \\
\text { Activities }\end{array}$ & \\
\hline $\begin{array}{l}\text { Disaster } \\
\text { Declaration }\end{array}$ & $\begin{array}{l}\text { Disaster Declaration } \\
\text { Required }\end{array}$ & \\
\hline & $\begin{array}{l}\text { Unusual Circumstances } \\
\text { Accepted }\end{array}$ & \\
\hline Projects Funded & $\begin{array}{l}\text { Type of Facility or Land } \\
\text { Funded }\end{array}$ & \\
\hline & Other Assistance Provided & \\
\hline & Project Types & $\begin{array}{l}\text { Main Projects: Trainings and Workshops, } \\
\text { Adaptation Planning and Data Development for } \\
\text { resilient Decision-making, Ocean and Coastal } \\
\text { Management Planning, and Capacity Building. }\end{array}$ \\
\hline $\begin{array}{l}\text { Financial } \\
\text { Application }\end{array}$ & $\begin{array}{l}\text { Demonstrate Work is Cost } \\
\text { Effective }\end{array}$ & \\
\hline Requirements & $\begin{array}{l}\text { Demonstrate No Available } \\
\text { Help Found Elsewhere }\end{array}$ & \\
\hline & $\begin{array}{l}\text { Demonstrate Financial } \\
\text { History }\end{array}$ & \\
\hline $\begin{array}{l}\text { Other Application } \\
\text { Requirements \& } \\
\text { Criteria }\end{array}$ & $\begin{array}{l}\text { Existing Plan / Strategy } \\
\text { Required }\end{array}$ & $\begin{array}{l}\text { If it is a Category } 4 \text { proposing Implementation, need } \\
\text { to show Strategy exists or if it is a Category } 7 \\
\text { proposing to do implementation of a plan. }\end{array}$ \\
\hline & $\begin{array}{l}\text { Special Requirements or } \\
\text { Benefits for Special Flood } \\
\text { Hazard Areas }\end{array}$ & \\
\hline & $\begin{array}{l}\text { Participate / Good Standing } \\
\text { with National Flood } \\
\text { Insurance Program }\end{array}$ & \\
\hline & Existing Insurance Required & \\
\hline & $\begin{array}{l}\text { Demonstrate NEPA } \\
\text { Compliance }\end{array}$ & $\begin{array}{l}\text { If implementation requires NEPA, demonstrate } \\
\text { compliance prior to full award of funds. }\end{array}$ \\
\hline & Public Outreach Prioritized & \\
\hline & $\begin{array}{l}\text { Building Code Adoption } \\
\text { Required }\end{array}$ & \\
\hline & $\begin{array}{l}\text { Demonstrate Substantial } \\
\text { Damage }\end{array}$ & \\
\hline & Other Criteria & \\
\hline & Additional Comments & \\
\hline
\end{tabular}




\section{Department of Energy (DOE)}

\section{State Energy Program}

Link to Program: https://www.energy.gov/eere/wipo/state-energy-program

Description of Program: Provides annual funding and technical assistance to states, territories, and the District of Columbia to enhance energy security, advance state-led energy initiatives, and increase energy affordability.

\begin{tabular}{|c|c|c|}
\hline & Name of Program & State Energy Program \\
\hline \multirow[t]{2}{*}{ Resilience Focus } & $\begin{array}{l}\text { Resilience is a Program } \\
\text { Priority }\end{array}$ & $\mathrm{N}$ \\
\hline & $\begin{array}{l}\text { Mitigation, Planning, } \\
\text { Response, Recovery }\end{array}$ & Mitigation, Planning, Response \\
\hline \multirow[t]{3}{*}{ Program Funding } & Total Funds Available & $\$ 55$ million in FY2019 \\
\hline & $\begin{array}{l}\text { Funding Limitations Per } \\
\text { Application }\end{array}$ & Varies amongst the 56 state and territory programs \\
\hline & Cost Share Requirements & Minimum $20 \%$ state match requirement every year \\
\hline \multirow[t]{2}{*}{ Funding Timing } & Application Deadlines & $\begin{array}{l}\text { Formula grants are awarded annually to all states; } \\
\text { July } 1 \text { states are usually due in April and October } 1 \\
\text { states are due in May. }\end{array}$ \\
\hline & Length of Benefit & $\begin{array}{l}3 \text { years, but new applications must be submitted } \\
\text { each year }\end{array}$ \\
\hline \multirow{4}{*}{$\begin{array}{l}\text { Targeted } \\
\text { Applicants and } \\
\text { Recipients }\end{array}$} & Eligible Applicants & State \\
\hline & Eligible Subapplicants & $\mathrm{N} / \mathrm{A}$ \\
\hline & Eligible Recipients & $\mathrm{N} / \mathrm{A}$ \\
\hline & $\begin{array}{l}\text { Low-Income, Impoverished } \\
\text { Community Status } \\
\text { Prioritized }\end{array}$ & $\mathrm{N}$ \\
\hline \multirow{3}{*}{$\begin{array}{l}\text { Hazard } \\
\text { Categorization }\end{array}$} & Hazards Included & not hazard-focused \\
\hline & $\begin{array}{l}\text { Funding for Pre-disaster } \\
\text { Activities }\end{array}$ & $\mathrm{N} / \mathrm{A}$ \\
\hline & $\begin{array}{l}\text { Funding for Post-disaster } \\
\text { Activities }\end{array}$ & $N / A$ \\
\hline \multirow[t]{2}{*}{$\begin{array}{l}\text { Disaster } \\
\text { Declaration }\end{array}$} & $\begin{array}{l}\text { Disaster Declaration } \\
\text { Required }\end{array}$ & $N / A$ \\
\hline & $\begin{array}{l}\text { Unusual Circumstances } \\
\text { Accepted }\end{array}$ & $N / A$ \\
\hline \multirow[t]{3}{*}{ Projects Funded } & $\begin{array}{l}\text { Type of Facility or Land } \\
\text { Funded }\end{array}$ & Public \\
\hline & Other Assistance Provided & $\begin{array}{l}\text { Y - Technical Assistance. DOE provides states with } \\
\text { technical assistance and guidance in a collaborative } \\
\text { effort to assist with implementation of efficient and } \\
\text { effective proarams. }\end{array}$ \\
\hline & Project Types & $\begin{array}{l}\text {-State Energy Planning; } \\
\text { - Energy Emergency Planning and Response; } \\
\text { - Low-Cost Financing Programs for Energy } \\
\text { Efficiency; } \\
\text { - Energy Savings Performance Contracting; } \\
\text { - Innovative Energy Technology Demonstration } \\
\text { Projects; } \\
\text { - Partnerships with Local Governments for Energy } \\
\text { Efficiency Improvements; and } \\
\text { - School and Public Building Retrofit Programs. }\end{array}$ \\
\hline
\end{tabular}




\begin{tabular}{|c|c|c|}
\hline \multirow{3}{*}{$\begin{array}{l}\text { Financial } \\
\text { Application } \\
\text { Requirements }\end{array}$} & $\begin{array}{l}\text { Demonstrate Work is Cost } \\
\text { Effective }\end{array}$ & $N / A$ \\
\hline & $\begin{array}{l}\text { Demonstrate No Available } \\
\text { Help Found Elsewhere }\end{array}$ & $\mathrm{N} / \mathrm{A}$ \\
\hline & $\begin{array}{l}\text { Demonstrate Financial } \\
\text { History }\end{array}$ & $N / A$ \\
\hline \multirow{10}{*}{$\begin{array}{l}\text { Other Application } \\
\text { Requirements \& } \\
\text { Criteria }\end{array}$} & $\begin{array}{l}\text { Existing Plan / Strategy } \\
\text { Required }\end{array}$ & Energy Assurance Plan Required \\
\hline & $\begin{array}{l}\text { Special Requirements or } \\
\text { Benefits for Special Flood } \\
\text { Hazard Areas }\end{array}$ & $N / A$ \\
\hline & $\begin{array}{l}\text { Participate / Good Standing } \\
\text { with National Flood } \\
\text { Insurance Program }\end{array}$ & $N / A$ \\
\hline & Existing Insurance Required & $\mathrm{N} / \mathrm{A}$ \\
\hline & $\begin{array}{l}\text { Demonstrate NEPA } \\
\text { Compliance }\end{array}$ & $\begin{array}{l}\text { Y - projects must pass NEPA review (carried out by } \\
\text { DOE) }\end{array}$ \\
\hline & Public Outreach Prioritized & $\mathrm{N} / \mathrm{A}$ \\
\hline & $\begin{array}{l}\text { Building Code Adoption } \\
\text { Required }\end{array}$ & $\mathrm{N} / \mathrm{A}$ \\
\hline & $\begin{array}{l}\text { Demonstrate Substantial } \\
\text { Damage }\end{array}$ & $\mathrm{N} / \mathrm{A}$ \\
\hline & Other Criteria & $\mathrm{N} / \mathrm{A}$ \\
\hline & Additional Comments & $\mathrm{N} / \mathrm{A}$ \\
\hline
\end{tabular}




\section{Department of Labor (DOL)}

\section{Disaster Unemployment Assistance (DUA)}

\section{Link to Program: https://oui.doleta.gov/unemploy/disaster.asp}

Description of Program: provides financial assistance to individuals whose employment or selfemployment has been lost or interrupted as a direct result of a major disaster and who are not eligible for regular unemployment insurance benefits

\begin{tabular}{|c|c|c|}
\hline & Name of Program & Disaster Unemployment Assistance (DUA) \\
\hline \multirow[t]{2}{*}{ Resilience Focus } & $\begin{array}{l}\text { Resilience is a Program } \\
\text { Priority }\end{array}$ & \\
\hline & $\begin{array}{l}\text { Mitigation, Planning, } \\
\text { Response, Recovery }\end{array}$ & Response \\
\hline \multirow[t]{3}{*}{ Program Funding } & Total Funds Available & $\begin{array}{l}\text { Funded annually through discretionary } \\
\text { appropriations on a no-year basis }\end{array}$ \\
\hline & $\begin{array}{l}\text { Funding Limitations Per } \\
\text { Application }\end{array}$ & \\
\hline & Cost Share Requirements & \\
\hline \multirow[t]{2}{*}{ Funding Timing } & Application Deadlines & $\begin{array}{l}30 \text { days post announcement of availability of DUA } \\
\text { in state }\end{array}$ \\
\hline & Length of Benefit & up to 26 weeks post disaster \\
\hline \multirow{4}{*}{$\begin{array}{l}\text { Targeted } \\
\text { Applicants and } \\
\text { Recipients }\end{array}$} & Eligible Applicants & Individual \\
\hline & Eligible Subapplicants & $\mathrm{N}$ \\
\hline & Eligible Recipients & Individual \\
\hline & $\begin{array}{l}\text { Low-Income, Impoverished } \\
\text { Community Status } \\
\text { Prioritized }\end{array}$ & \\
\hline \multirow{3}{*}{$\begin{array}{l}\text { Hazard } \\
\text { Categorization }\end{array}$} & Hazards Included & All \\
\hline & $\begin{array}{l}\text { Funding for Pre-disaster } \\
\text { Activities }\end{array}$ & $\mathrm{N}$ \\
\hline & $\begin{array}{l}\text { Funding for Post-disaster } \\
\text { Activities }\end{array}$ & $\mathrm{Y}$ \\
\hline \multirow[t]{2}{*}{$\begin{array}{l}\text { Disaster } \\
\text { Declaration }\end{array}$} & $\begin{array}{l}\text { Disaster Declaration } \\
\text { Required }\end{array}$ & Y \\
\hline & $\begin{array}{l}\text { Unusual Circumstances } \\
\text { Accepted }\end{array}$ & $\mathrm{N}$ \\
\hline \multirow[t]{3}{*}{ Projects Funded } & $\begin{array}{l}\text { Type of Facility or Land } \\
\text { Funded }\end{array}$ & None \\
\hline & Other Assistance Provided & Y; unemployment assistance \\
\hline & Project Types & unemployment benefits/reemployment services \\
\hline \multirow{3}{*}{$\begin{array}{l}\text { Financial } \\
\text { Application } \\
\text { Requirements }\end{array}$} & $\begin{array}{l}\text { Demonstrate Work is Cost } \\
\text { Effective }\end{array}$ & \\
\hline & $\begin{array}{l}\text { Demonstrate No Available } \\
\text { Help Found Elsewhere }\end{array}$ & \\
\hline & $\begin{array}{l}\text { Demonstrate Financial } \\
\text { History }\end{array}$ & \\
\hline \multirow{3}{*}{$\begin{array}{l}\text { Other Application } \\
\text { Requirements \& } \\
\text { Criteria }\end{array}$} & $\begin{array}{l}\text { Existing Plan / Strategy } \\
\text { Required }\end{array}$ & \\
\hline & $\begin{array}{l}\text { Special Requirements or } \\
\text { Benefits for Special Flood } \\
\text { Hazard Areas }\end{array}$ & \\
\hline & $\begin{array}{l}\text { Participate / Good Standing } \\
\text { with National Flood } \\
\text { Insurance Program }\end{array}$ & \\
\hline
\end{tabular}




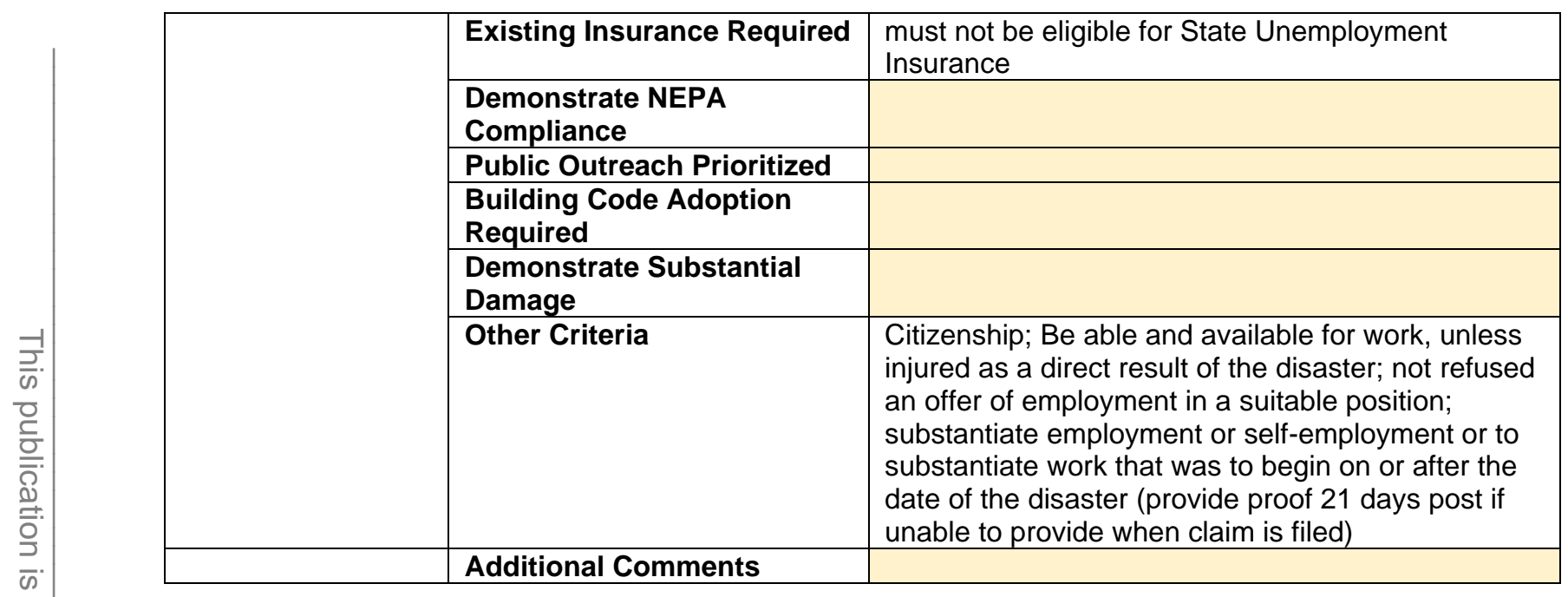




\section{Department of Transportation (DOT)}

\section{Federal Highway Administration (FHWA) -Emergency Relief Funding for Federally Owned Roads (ERFO) Program}

\section{Link to Program: https://www.fhwa.dot.gov/programadmin/erelief.cfm}

Description of Program: Supplements the commitment of resources by States, their political subdivisions, or other Federal highway agencies to help pay for unusually heavy expenses to repair damaged roads and bridges resulting from extraordinary conditions, including natural disasters

\begin{tabular}{|c|c|c|}
\hline & Name of Program & FHWA - Emergency Relief Funding \\
\hline \multirow[t]{2}{*}{ Resilience Focus } & $\begin{array}{l}\text { Resilience is a Program } \\
\text { Priority }\end{array}$ & $\begin{array}{l}\text { The Emergency Relief (ER) Program statute } \\
\text { authorizes funding to repair Federal-aid highways } \\
\text { and roads on Federal Lands to pre-disaster } \\
\text { conditions with an allowance to build to current } \\
\text { design standards. In some cases, current design } \\
\text { standards will provide for a more resilient repair } \\
\text { than existed prior to the disaster. Repairs beyond } \\
\text { that may incorporate resilience improvements when } \\
\text { it is demonstrated to be cost effective to do so. }\end{array}$ \\
\hline & $\begin{array}{l}\text { Mitigation, Planning, } \\
\text { Response, Recovery }\end{array}$ & $\begin{array}{l}\text { Recovery; the ER program has two categories: } \\
\text { emergency repairs and permanent repairs that } \\
\text { address recovery. }\end{array}$ \\
\hline \multirow[t]{3}{*}{ Program Funding } & Total Funds Available & $\begin{array}{l}\text { Typically } \$ 100 \text { million appropriated annually with } \\
\text { additional funding provided by Congress, as } \\
\text { needed, through supplemental appropriations. }\end{array}$ \\
\hline & $\begin{array}{l}\text { Funding Limitations Per } \\
\text { Application }\end{array}$ & $\mathrm{N}$ \\
\hline & Cost Share Requirements & $\begin{array}{l}100 \% \text { Fed cost share for emergency repairs; } 90 \% \\
\text { for permanent repairs to Interstates; } 80 \% \text { for other } \\
\text { permanent repairs. }\end{array}$ \\
\hline \multirow[t]{2}{*}{ Funding Timing } & Application Deadlines & Two years from the date of the disaster. \\
\hline & Length of Benefit & 180 day limit for emergency repairs. \\
\hline \multirow{4}{*}{$\begin{array}{l}\text { Targeted } \\
\text { Applicants and } \\
\text { Recipients }\end{array}$} & Eligible Applicants & State \\
\hline & Eligible Subapplicants & $\mathrm{N}$ \\
\hline & Eligible Recipients & State, Federal Land Management Agencies, Tribes. \\
\hline & $\begin{array}{l}\text { Low-Income, Impoverished } \\
\text { Community Status } \\
\text { Prioritized }\end{array}$ & \\
\hline \multirow{3}{*}{$\begin{array}{l}\text { Hazard } \\
\text { Categorization }\end{array}$} & Hazards Included & All \\
\hline & $\begin{array}{l}\text { Funding for Pre-disaster } \\
\text { Activities }\end{array}$ & $\mathrm{N}$ \\
\hline & $\begin{array}{l}\text { Funding for Post-disaster } \\
\text { Activities }\end{array}$ & $\mathrm{Y}$ \\
\hline \multirow[t]{2}{*}{$\begin{array}{l}\text { Disaster } \\
\text { Declaration }\end{array}$} & $\begin{array}{l}\text { Disaster Declaration } \\
\text { Required }\end{array}$ & $\begin{array}{l}\text { Y; Governor's emergency proclamation or } \\
\text { Presidential declaration of a major disaster. }\end{array}$ \\
\hline & $\begin{array}{l}\text { Unusual Circumstances } \\
\text { Accepted }\end{array}$ & $\begin{array}{l}\text { Emergency Relief funding is eligible for natural } \\
\text { disasters or catastrophic failures from an external } \\
\text { cause. }\end{array}$ \\
\hline \multirow[t]{3}{*}{ Projects Funded } & $\begin{array}{l}\text { Type of Facility or Land } \\
\text { Funded }\end{array}$ & Public \\
\hline & Other Assistance Provided & $\begin{array}{l}\text { Y; some cases transit services eligible for } \\
\text { reimbursement }\end{array}$ \\
\hline & Project Types & $\begin{array}{l}\text { Emergency repairs for Federal-Aid highways and } \\
\text { roads on Federal Lands. }\end{array}$ \\
\hline
\end{tabular}




\begin{tabular}{|c|c|c|}
\hline \multirow[t]{3}{*}{$\begin{array}{l}\text { Financial } \\
\text { Application } \\
\text { Requirements }\end{array}$} & $\begin{array}{l}\text { Demonstrate Work is Cost } \\
\text { Effective }\end{array}$ & $\begin{array}{l}\text { Improvements require a cost-effective justification } \\
\text { to demonstrate repair will provide a benefit to the } \\
\text { Emergency Relief program. }\end{array}$ \\
\hline & $\begin{array}{l}\text { Demonstrate No Available } \\
\text { Help Found Elsewhere }\end{array}$ & \\
\hline & $\begin{array}{l}\text { Demonstrate Financial } \\
\text { History }\end{array}$ & \\
\hline \multirow{9}{*}{$\begin{array}{l}\text { Other Application } \\
\text { Requirements \& } \\
\text { Criteria }\end{array}$} & $\begin{array}{l}\text { Existing Plan / Strategy } \\
\text { Required }\end{array}$ & \\
\hline & $\begin{array}{l}\text { Special Requirements or } \\
\text { Benefits for Special Flood } \\
\text { Hazard Areas }\end{array}$ & \\
\hline & $\begin{array}{l}\text { Participate / Good Standing } \\
\text { with National Flood } \\
\text { Insurance Program }\end{array}$ & \\
\hline & Existing Insurance Required & $\begin{array}{l}\text { Environmental Review (ER) National Environmental } \\
\text { Policy Act (NEPA) requirements are consistent } \\
\text { state-by-state. ER projects are subject to NEPA } \\
\text { compliance (though emergency repairs and most } \\
\text { permanent repairs are listed categorical } \\
\text { exclusions). }\end{array}$ \\
\hline & $\begin{array}{l}\text { Demonstrate NEPA } \\
\text { Compliance }\end{array}$ & Depends on the State \\
\hline & Public Outreach Prioritized & \\
\hline & $\begin{array}{l}\text { Building Code Adoption } \\
\text { Required }\end{array}$ & \\
\hline & $\begin{array}{l}\text { Demonstrate Substantial } \\
\text { Damage }\end{array}$ & $\begin{array}{l}\text { Y; Incident must cause at least } \$ 700,000 \text { in eligible } \\
\text { damages to qualify for funding; Requires } \\
\text { completion of site damage assessments and a } \\
\text { program of projects identifying locations and costs } \\
\text { of eligible damages. }\end{array}$ \\
\hline & Other Criteria & \\
\hline
\end{tabular}


Federal Transit Administration (FTA) - Public Transportation Emergency Relief Program Link to Program: https://www.transit.dot.gov/funding/grant-programs/emergency-relief-program Description of Program: Reimburse public transit operators in the aftermath of an emergency or major disaster to help pay for protecting, repairing, or replacing equipment and facilities that may suffer or have suffered serious damage. Funds the operating costs of evacuation, rescue operations, or temporary public transportation service during or after an emergency.

\begin{tabular}{|c|c|c|}
\hline & Name of Program & Public Transportation Emergency Relief Program \\
\hline \multirow[t]{2}{*}{ Resilience Focus } & $\begin{array}{l}\text { Resilience is a Program } \\
\text { Priority }\end{array}$ & $\begin{array}{l}\text { Depends on the appropriation (Appropriations to } \\
\text { date: Hurricane Sandy, Hurricanes } \\
\text { Harvey/Irma/Maria, and major declared disasters } \\
\text { that occurred in calendar year 2018) }\end{array}$ \\
\hline & $\begin{array}{l}\text { Mitigation, Planning, } \\
\text { Response, Recovery }\end{array}$ & Response \\
\hline \multirow[t]{3}{*}{ Program Funding } & Total Funds Available & $\begin{array}{l}\text { Hurricane Sandy appropriation - } \$ 10.9 \text { billion } \\
\text { Hurricane Harvey/lrma/Maria appropriation - } \$ 330 \\
\text { million } \\
\text { Natural disasters in } 2018 \text { - } \$ 10.5 \text { million } \\
\text { [Note: majority of funding is focused on recovery; } \\
\text { resilience-specific funding amounts are smaller] }\end{array}$ \\
\hline & $\begin{array}{l}\text { Funding Limitations Per } \\
\text { Application }\end{array}$ & $\begin{array}{l}\text { No max per application, although amounts allocated } \\
\text { to recipients may be capped if appropriation is not } \\
\text { large enough to address all reported eligible } \\
\text { expenses }\end{array}$ \\
\hline & Cost Share Requirements & $\begin{array}{l}80 \% \text { Fed cost share for capital projects; } 50 \% \text { for } \\
\text { operations projects; unless waived by DOT } \\
\text { Secretary }\end{array}$ \\
\hline \multirow[t]{2}{*}{ Funding Timing } & Application Deadlines & $\begin{array}{l}60 \text { days to submit a damage assessment report post } \\
\text { incident }\end{array}$ \\
\hline & Length of Benefit & Funding is made available until expended \\
\hline \multirow{4}{*}{$\begin{array}{l}\text { Targeted } \\
\text { Applicants and } \\
\text { Recipients }\end{array}$} & Eligible Applicants & State; Tribe; Local; Public Transit Systems \\
\hline & Eligible Subapplicants & $\begin{array}{l}\text { Entities that provide public transportation service but } \\
\text { not receive funding directly from FTA }\end{array}$ \\
\hline & Eligible Recipients & $\begin{array}{l}\text { State; Tribe; Local; Public Transit Systems; Public } \\
\text { Transportation Providers }\end{array}$ \\
\hline & $\begin{array}{l}\text { Low-Income, Impoverished } \\
\text { Community Status } \\
\text { Prioritized }\end{array}$ & $\mathrm{N}$ \\
\hline \multirow{3}{*}{$\begin{array}{l}\text { Hazard } \\
\text { Categorization }\end{array}$} & Hazards Included & All \\
\hline & $\begin{array}{l}\text { Funding for Pre-disaster } \\
\text { Activities }\end{array}$ & $\begin{array}{l}\mathrm{N} \text { (except with special pre-award authority is } \\
\text { granted) }\end{array}$ \\
\hline & $\begin{array}{l}\text { Funding for Post-disaster } \\
\text { Activities }\end{array}$ & $\mathrm{Y}$ \\
\hline \multirow[t]{2}{*}{$\begin{array}{l}\text { Disaster } \\
\text { Declaration }\end{array}$} & $\begin{array}{l}\text { Disaster Declaration } \\
\text { Required }\end{array}$ & Y; State or President \\
\hline & $\begin{array}{l}\text { Unusual Circumstances } \\
\text { Accepted }\end{array}$ & $\mathrm{N}$ \\
\hline \multirow[t]{3}{*}{ Projects Funded } & $\begin{array}{l}\text { Type of Facility or Land } \\
\text { Funded }\end{array}$ & Public \\
\hline & Other Assistance Provided & Y; temporary public transit, rescue operations \\
\hline & Project Types & $\begin{array}{l}\text { repair or replace damaged public transportation } \\
\text { systems; operating costs of evacuation, rescue } \\
\text { operations, and temporary public transit; resilience } \\
\text { projects on an incident-by-incident basis }\end{array}$ \\
\hline
\end{tabular}




\begin{tabular}{|c|c|c|}
\hline \multirow{3}{*}{$\begin{array}{l}\text { Financial } \\
\text { Application } \\
\text { Requirements }\end{array}$} & $\begin{array}{l}\text { Demonstrate Work is Cost } \\
\text { Effective }\end{array}$ & $\begin{array}{l}\text { Depends on appropriation - Yes (with the hazard } \\
\text { mitigation cost effectiveness tool as a resource) }\end{array}$ \\
\hline & $\begin{array}{l}\text { Demonstrate No Available } \\
\text { Help Found Elsewhere }\end{array}$ & $\begin{array}{l}\text { When FTA ER appropriated funds, transit systems } \\
\text { must seek reimbursement from FTA first }\end{array}$ \\
\hline & $\begin{array}{l}\text { Demonstrate Financial } \\
\text { History }\end{array}$ & $\mathrm{N}$ \\
\hline \multirow{9}{*}{$\begin{array}{l}\text { Other Application } \\
\text { Requirements \& } \\
\text { Criteria }\end{array}$} & $\begin{array}{l}\text { Existing Plan / Strategy } \\
\text { Required }\end{array}$ & $\mathrm{N}$ \\
\hline & $\begin{array}{l}\text { Special Requirements or } \\
\text { Benefits for Special Flood } \\
\text { Hazard Areas }\end{array}$ & $\begin{array}{l}\text { Y; SFHA must comply with a Federal Flood Risk } \\
\text { Management Standard to receive funding; must } \\
\text { have flood insurance }\end{array}$ \\
\hline & $\begin{array}{l}\text { Participate / Good Standing } \\
\text { with National Flood } \\
\text { Insurance Program }\end{array}$ & $\begin{array}{l}\text { Recipients must obtain and maintain flood insurance } \\
\text { as required by the Flood Disaster Protection Act of } \\
1973\end{array}$ \\
\hline & Existing Insurance Required & $\begin{array}{l}\text { FTA recipients are required to insure Federally } \\
\text { funded assets at the same level as locally funded } \\
\text { assets }\end{array}$ \\
\hline & $\begin{array}{l}\text { Demonstrate NEPA } \\
\text { Compliance }\end{array}$ & $\begin{array}{l}\text { Y; EIS or EA unless projects receive a categorical } \\
\text { exclusion }\end{array}$ \\
\hline & Public Outreach Prioritized & $\mathrm{N}$ \\
\hline & $\begin{array}{l}\text { Building Code Adoption } \\
\text { Required }\end{array}$ & $\begin{array}{l}\text { Hurricane Sandy resilience projects intended to } \\
\text { protect against flooding and that are located within } \\
\text { the SFHA must be designed and elevated or } \\
\text { otherwise flood-proofed to the best available Base } \\
\text { Flood Elevation (BFE) elevation released by FEMA } \\
\text { plus one foot }\end{array}$ \\
\hline & $\begin{array}{l}\text { Demonstrate Substantial } \\
\text { Damage }\end{array}$ & Y; damage assessment report \\
\hline & Other Criteria & $\begin{array}{l}\text { Conduct a preliminary field survey to create a } \\
\text { damage assessment report }\end{array}$ \\
\hline
\end{tabular}




\section{Economic Development Administration (EDA)}

\section{Economic Adjustment Assistance Grant}

Link to Program: https://www.eda.gov/pdf/about/Economic-Adjustment-Assistance-Program-1Pager.pdf

Description of Program: Provides a wide range of technical, planning, and public works and infrastructure assistance in regions experiencing adverse economic changes that may occur suddenly or over time.

\begin{tabular}{|c|c|c|}
\hline & Name of Program & Economic Adjustment Assistance Grant \\
\hline \multirow[t]{2}{*}{ Resilience Focus } & $\begin{array}{l}\text { Resilience is a Program } \\
\text { Priority }\end{array}$ & $\mathrm{Y}$ \\
\hline & $\begin{array}{l}\text { Mitigation, Planning, } \\
\text { Response, Recovery }\end{array}$ & Mitigation, Planning \\
\hline \multirow[t]{3}{*}{ Program Funding } & Total Funds Available & FY19 appropriations $\$ 37 \mathrm{M}$ \\
\hline & $\begin{array}{l}\text { Funding Limitations Per } \\
\text { Application }\end{array}$ & $\begin{array}{l}\text { None. Average award size is approximately } \$ 820 \mathrm{~K} \text {; } \\
\text { generally range from } \$ 100 \mathrm{~K} \text { to } \$ 1.25 \mathrm{M} \\
\text { The average size of an EAA investment has been } \\
\text { approximately } \$ 650,000 \text { and investments generally } \\
\text { range from } \$ 150,000 \text { to } \$ 1,000,000 \text {. Historically, } \\
\text { EDA has awarded funds for between } 70 \text { and } 140 \\
\text { EAA projects a year. }\end{array}$ \\
\hline & Cost Share Requirements & $\begin{array}{l}\text { Generally } 50 \% \text { Federal cost share, but Federal cost } \\
\text { share can increase to } 80 \% \text { or even } 100 \% \text { in certain } \\
\text { circumstances. Non-Federal matching share may } \\
\text { include in-kind contributions }\end{array}$ \\
\hline \multirow[t]{2}{*}{ Funding Timing } & Application Deadlines & Rolling basis \\
\hline & Length of Benefit & $\begin{array}{l}\text { Typically } 12 \text { to } 36 \text { months for infrastructure projects } \\
\text { with all infrastructure projects needing to be } \\
\text { complete within } 5 \text { years of award. } 12-18 \text { months for } \\
\text { non-infrastructure projects }\end{array}$ \\
\hline \multirow[t]{4}{*}{$\begin{array}{l}\text { Targeted } \\
\text { Applicants and } \\
\text { Recipients }\end{array}$} & Eligible Applicants & $\begin{array}{l}\text { State; Local; other political subdivisions of a state; } \\
\text { consortium of political subdivisions; tribes; higher- } \\
\text { ed; public or nonprofit; economic development } \\
\text { district organizations }\end{array}$ \\
\hline & Eligible Subapplicants & Same as applicants \\
\hline & Eligible Recipients & Same as applicants \\
\hline & $\begin{array}{l}\text { Low-Income, Impoverished } \\
\text { Community Status } \\
\text { Prioritized }\end{array}$ & $\begin{array}{l}\text { Y; this grant program is statutorily required to target } \\
\text { distressed communities (Public Works and } \\
\text { Economic Development Act of } 1965-42 \text { U.S.C. § } \\
3121 \text { et seq.) } \\
\text { Economic distress defined by: (i) an unemployment } \\
\text { rate that is, for the most recent } 24 \text {-month period for } \\
\text { which data are available, at least one percentage } \\
\text { point greater than the national average } \\
\text { unemployment rate; (ii) per capita income that is, } \\
\text { for the most recent period for which data are } \\
\text { available, } 80 \text { percent or less of the national average } \\
\text { per capita income; or (iii) a "Special Need," as } \\
\text { determined by EDA. }\end{array}$ \\
\hline $\begin{array}{l}\text { Hazard } \\
\text { Categorization }\end{array}$ & Hazards Included & $\begin{array}{l}\text { Y - the Economic Adjustment Assistance Grant } \\
\text { program includes hazard mitigation among its many }\end{array}$ \\
\hline
\end{tabular}




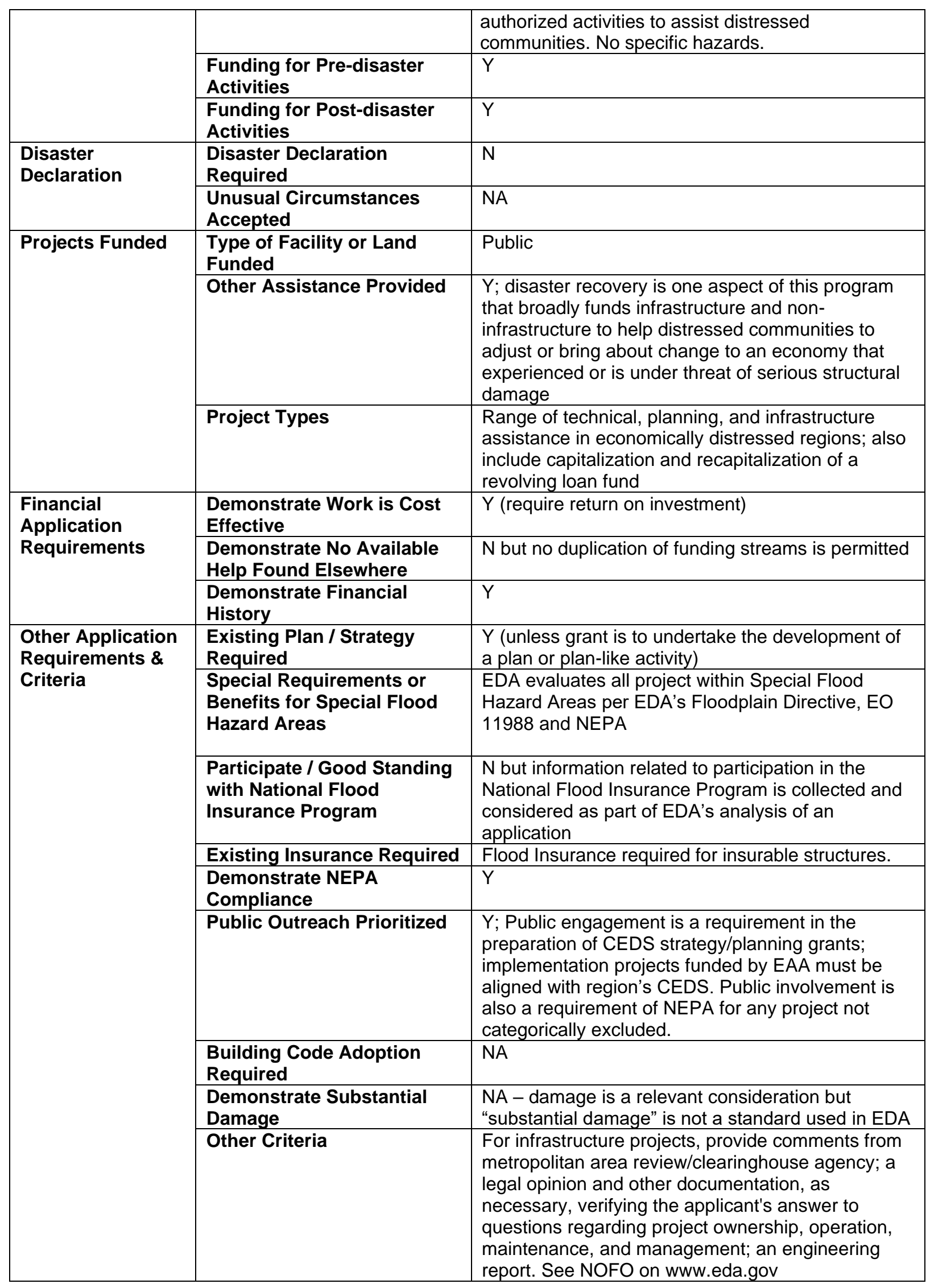




\section{Economic Development Disaster Supplemental Funding}

Link to Program: https://www.eda.gov/disaster-recovery/supplemental/

Description of Program: Help regions recover from the economic harm and distress resulting from natural disasters to rebuild stronger, more resilient economies. EDA Disaster Supplemental funding can also be used for infrastructure (water/wastewater, roads, ports, buildings) with an economic development purpose.

\begin{tabular}{|c|c|c|}
\hline & Name of Program & $\begin{array}{l}\text { Economic Development Disaster Supplemental } \\
\text { Funding }\end{array}$ \\
\hline \multirow[t]{2}{*}{ Resilience Focus } & $\begin{array}{l}\text { Resilience is a Program } \\
\text { Priority }\end{array}$ & $\mathrm{Y}$ \\
\hline & $\begin{array}{l}\text { Mitigation, Planning, } \\
\text { Response, Recovery }\end{array}$ & Mitigation, Recovery \\
\hline \multirow[t]{3}{*}{ Program Funding } & Total Funds Available & $\begin{array}{l}\$ 587 \mathrm{M} \text { in FY } 18 \text { funds appropriated for } 2017 \\
\text { disasters. } \\
\$ 600 \mathrm{M} \text { in FY19 funds appropriated for additional } \\
\text { Economic Adjustment Assistance (EAA) Program } \\
\text { funds for } 2018 \text { major disasters and } 2019 \text { flood and } \\
\text { tornadoes (only). }\end{array}$ \\
\hline & $\begin{array}{l}\text { Funding Limitations Per } \\
\text { Application }\end{array}$ & $\begin{array}{l}\text { None. Average award size is approximately } \$ 2.3 \mathrm{M} \text {; } \\
\text { generally range from } \$ 10 \mathrm{~K} \text { to } \$ 32 \mathrm{M}\end{array}$ \\
\hline & Cost Share Requirements & $\begin{array}{l}50 \% \text { to } 80 \% \text { Federal cost share. Due to disaster } \\
\text { distress level } 80 \% \text { Federal cost share is the most } \\
\text { common rate. Non-Federal matching share may } \\
\text { include in-kind contributions }\end{array}$ \\
\hline \multirow[t]{2}{*}{ Funding Timing } & Application Deadlines & Rolling basis \\
\hline & Length of Benefit & $\begin{array}{l}\text { Typically } 12 \text { to } 48 \text { months for infrastructure projects } \\
\text { with all infrastructure projects needing to be } \\
\text { complete within } 5 \text { years of award. } 12-18 \text { months for } \\
\text { strategy planning grants }\end{array}$ \\
\hline \multirow[t]{4}{*}{$\begin{array}{l}\text { Targeted } \\
\text { Applicants and } \\
\text { Recipients }\end{array}$} & Eligible Applicants & $\begin{array}{l}\text { State; Local; other political subdivisions of a state; } \\
\text { consortium of political subdivisions; tribes; higher-ed; } \\
\text { public or nonprofit; economic development district } \\
\text { organizations }\end{array}$ \\
\hline & Eligible Subapplicants & Same as applicants \\
\hline & Eligible Recipients & Same as applicants \\
\hline & $\begin{array}{l}\text { Low-Income, Impoverished } \\
\text { Community Status } \\
\text { Prioritized }\end{array}$ & Eligible applicants in Disaster Impacted Counties \\
\hline \multirow[t]{3}{*}{$\begin{array}{l}\text { Hazard } \\
\text { Categorization }\end{array}$} & Hazards Included & $\begin{array}{l}\text { Determined by the nature of Disaster Declaration. All } \\
\text { hazard approach allowed if project is also tied back } \\
\text { to declared disaster }\end{array}$ \\
\hline & $\begin{array}{l}\text { Funding for Pre-disaster } \\
\text { Activities }\end{array}$ & $\mathrm{N}$ \\
\hline & $\begin{array}{l}\text { Funding for Post-disaster } \\
\text { Activities }\end{array}$ & $\mathrm{Y}$ \\
\hline \multirow[t]{2}{*}{$\begin{array}{l}\text { Disaster } \\
\text { Declaration }\end{array}$} & $\begin{array}{l}\text { Disaster Declaration } \\
\text { Required }\end{array}$ & $\mathrm{Y}$ \\
\hline & $\begin{array}{l}\text { Unusual Circumstances } \\
\text { Accepted }\end{array}$ & $\mathrm{N}$ \\
\hline \multirow[t]{2}{*}{ Projects Funded } & $\begin{array}{l}\text { Type of Facility or Land } \\
\text { Funded }\end{array}$ & Public \\
\hline & Other Assistance Provided & Y; strategy development funding \\
\hline
\end{tabular}




\begin{tabular}{|c|c|c|}
\hline & Project Types & $\begin{array}{l}\text { Public works/infrastructure construction, strategy } \\
\text { development/planning and capitalization and } \\
\text { recapitalization of a revolving loan fund. }\end{array}$ \\
\hline \multirow{3}{*}{$\begin{array}{l}\text { Financial } \\
\text { Application } \\
\text { Requirements }\end{array}$} & $\begin{array}{l}\text { Demonstrate Work is Cost } \\
\text { Effective }\end{array}$ & $\mathrm{Y}$ (require return on investment) \\
\hline & $\begin{array}{l}\text { Demonstrate No Available } \\
\text { Help Found Elsewhere }\end{array}$ & $\mathrm{N}$ but no duplication of funding streams is permitted \\
\hline & $\begin{array}{l}\text { Demonstrate Financial } \\
\text { History }\end{array}$ & $\mathrm{Y}$ \\
\hline \multirow[t]{9}{*}{$\begin{array}{l}\text { Other Application } \\
\text { Requirements \& } \\
\text { Criteria }\end{array}$} & $\begin{array}{l}\text { Existing Plan / Strategy } \\
\text { Required }\end{array}$ & $\begin{array}{l}\text { Y - EDA encourages applications based on long- } \\
\text { term, regionally oriented, existing economic } \\
\text { development or redevelopment strategies. } \\
\text { Applications must be consistent with a } \\
\text { Comprehensive Economic Development Strategy } \\
\text { (CEDS) or a CEDS equivalent plan }\end{array}$ \\
\hline & $\begin{array}{l}\text { Special Requirements or } \\
\text { Benefits for Special Flood } \\
\text { Hazard Areas }\end{array}$ & $\begin{array}{l}\text { EDA evaluates all project within Special Flood } \\
\text { Hazard Areas per } \\
\text { EDA's Floodplain Directive, EO } 11988 \text { and NEPA }\end{array}$ \\
\hline & $\begin{array}{l}\text { Participate / Good Standing } \\
\text { with National Flood } \\
\text { Insurance Program }\end{array}$ & $\begin{array}{l}\mathrm{N} \text { but information related to participation in the } \\
\text { National Flood Insurance Program is collected and } \\
\text { considered as part of EDA's analysis of an } \\
\text { application }\end{array}$ \\
\hline & Existing Insurance Required & $\begin{array}{l}\text { Flood Insurance required for any and all insurable } \\
\text { structures. }\end{array}$ \\
\hline & $\begin{array}{l}\text { Demonstrate NEPA } \\
\text { Compliance }\end{array}$ & 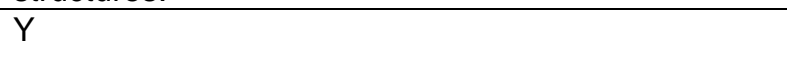 \\
\hline & Public Outreach Prioritized & $\begin{array}{l}\text { Y; Public engagement is a requirement in the } \\
\text { preparation of CEDS strategy/planning grants. } \\
\text { Alignment with the CEDS is required for all projects. } \\
\text { Public involvement is also a requirement of NEPA for } \\
\text { any project not categorically excluded. }\end{array}$ \\
\hline & $\begin{array}{l}\text { Building Code Adoption } \\
\text { Required }\end{array}$ & NA \\
\hline & $\begin{array}{l}\text { Demonstrate Substantial } \\
\text { Damage }\end{array}$ & $\begin{array}{l}\text { NA - damage is a relevant consideration but } \\
\text { "substantial damage" is not a standard used in EDA }\end{array}$ \\
\hline & Other Criteria & $\begin{array}{l}\text { Applicants must include a narrative attachment in } \\
\text { application materials, describing nexus between } \\
\text { proposed project scope of work and disaster } \\
\text { recovery and resilience efforts } \\
\text { See NOFO on www.eda.gov }\end{array}$ \\
\hline
\end{tabular}




\section{Economic Development Support for Planning Organizations}

Link to Program: https://www.eda.gov/pdf/about/Planning-Program-1-Pager.pdf

Description of Program: Provides essential investment support to district organizations, Native American organizations, states, sub-state planning regions, urban counties, cities and other eligible recipient to assist in planning

\begin{tabular}{|c|c|c|}
\hline & Name of Program & $\begin{array}{l}\text { Economic Development Support for Planning } \\
\text { Organizations }\end{array}$ \\
\hline \multirow[t]{2}{*}{ Resilience Focus } & $\begin{array}{l}\text { Resilience is a Program } \\
\text { Priority }\end{array}$ & $\mathrm{Y}$ \\
\hline & $\begin{array}{l}\text { Mitigation, Planning, } \\
\text { Response, Recovery }\end{array}$ & Planning \\
\hline \multirow[t]{3}{*}{ Program Funding } & Total Funds Available & FY19 appropriations $\$ 33 \mathrm{M}$ \\
\hline & $\begin{array}{l}\text { Funding Limitations Per } \\
\text { Application }\end{array}$ & $\begin{array}{l}\text { None. Average award size is approximately } \$ 70 \mathrm{~K} \text {; } \\
\text { generally range from } \$ 40 \mathrm{~K} \text { to } \$ 200 \mathrm{~K}\end{array}$ \\
\hline & Cost Share Requirements & $\begin{array}{l}\text { Generally } 50 \% \text { Federal cost share, but Federal cost } \\
\text { share can increase to } 80 \% \text { or even } 100 \% \text { in certain } \\
\text { circumstances. Non-Federal matching share may } \\
\text { include in-kind contributions }\end{array}$ \\
\hline \multirow[t]{2}{*}{ Funding Timing } & Application Deadlines & Rolling basis \\
\hline & Length of Benefit & Typically 12 to 36 months \\
\hline \multirow{4}{*}{$\begin{array}{l}\text { Targeted } \\
\text { Applicants and } \\
\text { Recipients }\end{array}$} & Eligible Applicants & Tribes; economic development district organizations \\
\hline & Eligible Subapplicants & Same as applicants \\
\hline & Eligible Recipients & Same as applicants \\
\hline & $\begin{array}{l}\text { Low-Income, Impoverished } \\
\text { Community Status } \\
\text { Prioritized }\end{array}$ & $\mathrm{N}$ \\
\hline \multirow{3}{*}{$\begin{array}{l}\text { Hazard } \\
\text { Categorization }\end{array}$} & Hazards Included & NA \\
\hline & $\begin{array}{l}\text { Funding for Pre-disaster } \\
\text { Activities }\end{array}$ & $\begin{array}{l}\text { Y; as it relates to a comprehensive regional } \\
\text { economic strategy }\end{array}$ \\
\hline & $\begin{array}{l}\text { Funding for Post-disaster } \\
\text { Activities }\end{array}$ & 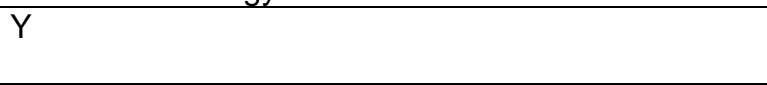 \\
\hline \multirow[t]{2}{*}{$\begin{array}{l}\text { Disaster } \\
\text { Declaration }\end{array}$} & $\begin{array}{l}\text { Disaster Declaration } \\
\text { Required }\end{array}$ & $\mathrm{N}$ \\
\hline & $\begin{array}{l}\text { Unusual Circumstances } \\
\text { Accepted }\end{array}$ & NA \\
\hline \multirow[t]{3}{*}{ Projects Funded } & $\begin{array}{l}\text { Type of Facility or Land } \\
\text { Funded }\end{array}$ & NA \\
\hline & Other Assistance Provided & Y; strategy development funding \\
\hline & Project Types & $\begin{array}{l}\text { Planning assistance (short-term/site specific and } \\
\text { long term strategic economic development } \\
\text { planning) }\end{array}$ \\
\hline \multirow{3}{*}{$\begin{array}{l}\text { Financial } \\
\text { Application } \\
\text { Requirements }\end{array}$} & $\begin{array}{l}\text { Demonstrate Work is Cost } \\
\text { Effective }\end{array}$ & Y (require return on investment) \\
\hline & $\begin{array}{l}\text { Demonstrate No Available } \\
\text { Help Found Elsewhere }\end{array}$ & $\mathrm{N}$ but no duplication of funding streams is permitted \\
\hline & $\begin{array}{l}\text { Demonstrate Financial } \\
\text { History }\end{array}$ & $\mathrm{Y}$ \\
\hline \multirow{2}{*}{$\begin{array}{l}\text { Other Application } \\
\text { Requirements \& } \\
\text { Criteria }\end{array}$} & $\begin{array}{l}\text { Existing Plan / Strategy } \\
\text { Required }\end{array}$ & $\mathrm{N}$ \\
\hline & $\begin{array}{l}\text { Special Requirements or } \\
\text { Benefits for Special Flood } \\
\text { Hazard Areas }\end{array}$ & $\begin{array}{l}\text { EDA evaluates all project within Special Flood } \\
\text { Hazard Areas per EDA's Floodplain Directive, EO } \\
11988 \text { and NEPA }\end{array}$ \\
\hline
\end{tabular}




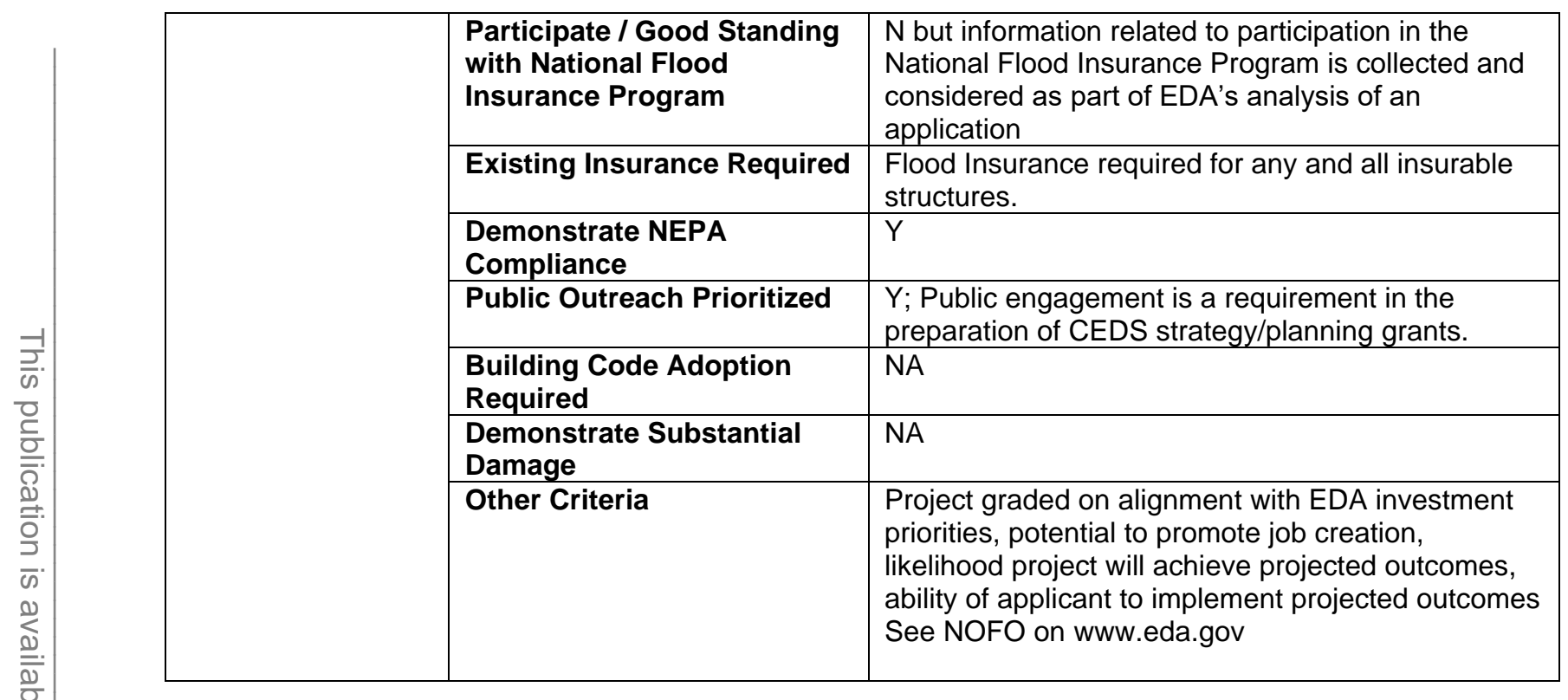




\section{Public Works and Economic Development Facilities}

Link to Program: https://www.eda.gov/pdf/about/Public-Works-Program-1-Pager.pdf

Description of Program: Helps distressed communities revitalize, expand, and upgrade their physical infrastructure. Enables communities to attract new industry; encourage business expansion; diversify local economies; and generate or retain long-term, private-sector jobs and investment through the acquisition or development of land and infrastructure improvements needed for the successful establishment or expansion of industrial or commercial enterprises.

\begin{tabular}{|c|c|c|}
\hline & Name of Program & $\begin{array}{l}\text { Investment for Public Works and Economic } \\
\text { Development Facilities }\end{array}$ \\
\hline \multirow[t]{2}{*}{ Resilience Focus } & $\begin{array}{l}\text { Resilience is a Program } \\
\text { Priority }\end{array}$ & 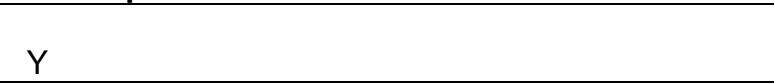 \\
\hline & $\begin{array}{l}\text { Mitigation, Planning, } \\
\text { Response, Recovery }\end{array}$ & Mitigation, Recovery \\
\hline \multirow[t]{3}{*}{ Program Funding } & Total Funds Available & FY19 appropriations $\$ 117.5 \mathrm{M}$ \\
\hline & $\begin{array}{l}\text { Funding Limitations Per } \\
\text { Application }\end{array}$ & $\begin{array}{l}\text { None. Average award size is approximately } \$ 1.4 \mathrm{M} \text {; } \\
\text { generally range from } \$ 200 \mathrm{~K} \text { to } \$ 3 \mathrm{M} \\
\text { The average size of a Public Works investment has } \\
\text { been approximately } \$ 1.4 \text { million and investments } \\
\text { generally range from } \$ 600,000 \text { to } \$ 3,000,000 \text {. } \\
\text { Historically, EDA has awarded funds for between } \\
80 \text { and } 150 \text { Public Works projects a year. }\end{array}$ \\
\hline & Cost Share Requirements & $\begin{array}{l}\text { Generally } 50 \% \text { Federal cost share, but Federal cost } \\
\text { share can increase to } 80 \% \text { or even } 100 \% \text { in certain } \\
\text { circumstances. Non-Federal matching share may } \\
\text { include in-kind contributions }\end{array}$ \\
\hline \multirow{2}{*}{ Funding Timing } & Application Deadlines & Rolling basis \\
\hline & Length of Benefit & $\begin{array}{l}\text { Typically } 12 \text { to } 48 \text { months for infrastructure projects } \\
\text { with all infrastructure projects needing to be } \\
\text { complete within } 5 \text { years of award }\end{array}$ \\
\hline \multirow[t]{4}{*}{$\begin{array}{l}\text { Targeted } \\
\text { Applicants and } \\
\text { Recipients }\end{array}$} & Eligible Applicants & $\begin{array}{l}\text { State; Local; other political subdivisions of a state; } \\
\text { consortium of political subdivisions; tribes; higher- } \\
\text { ed; public or nonprofit; economic development } \\
\text { district organizations }\end{array}$ \\
\hline & Eligible Subapplicants & Same as applicants \\
\hline & Eligible Recipients & Same as applicants \\
\hline & $\begin{array}{l}\text { Low-Income, Impoverished } \\
\text { Community Status } \\
\text { Prioritized }\end{array}$ & $\begin{array}{l}\text { Y; this grant program is statutorily required to target } \\
\text { distressed communities (Public Works and } \\
\text { Economic Development Act of } 1965-42 \text { U.S.C. } \S \\
3121 \text { et seq.) Please see previous definition. }\end{array}$ \\
\hline \multirow{3}{*}{$\begin{array}{l}\text { Hazard } \\
\text { Categorization }\end{array}$} & Hazards Included & NA \\
\hline & $\begin{array}{l}\text { Funding for Pre-disaster } \\
\text { Activities }\end{array}$ & $\mathrm{Y}$ \\
\hline & $\begin{array}{l}\text { Funding for Post-disaster } \\
\text { Activities }\end{array}$ & $\mathrm{Y}$ \\
\hline \multirow[t]{2}{*}{$\begin{array}{l}\text { Disaster } \\
\text { Declaration }\end{array}$} & $\begin{array}{l}\text { Disaster Declaration } \\
\text { Required }\end{array}$ & $\mathrm{N}$ \\
\hline & $\begin{array}{l}\text { Unusual Circumstances } \\
\text { Accepted }\end{array}$ & NA \\
\hline \multirow[t]{2}{*}{ Projects Funded } & $\begin{array}{l}\text { Type of Facility or Land } \\
\text { Funded }\end{array}$ & Public \\
\hline & Other Assistance Provided & $\begin{array}{l}\text { Y; disaster recovery is one aspect of this program } \\
\text { that empowers distressed communities to revitalize, }\end{array}$ \\
\hline
\end{tabular}




\begin{tabular}{|c|c|c|}
\hline & & $\begin{array}{l}\text { expand and upgrade physical infrastructure to } \\
\text { attract new industry, encourage business } \\
\text { expansion, diversify local economies, and generate } \\
\text { or retain long-term, private sector jobs and } \\
\text { investment }\end{array}$ \\
\hline & Project Types & Infrastructure/ public facilities construction \\
\hline \multirow{3}{*}{$\begin{array}{l}\text { Financial } \\
\text { Application } \\
\text { Requirements }\end{array}$} & $\begin{array}{l}\text { Demonstrate Work is Cost } \\
\text { Effective }\end{array}$ & $\mathrm{Y}$ (require return on investment) \\
\hline & $\begin{array}{l}\text { Demonstrate No Available } \\
\text { Help Found Elsewhere }\end{array}$ & $\mathrm{N}$ but no duplication of funding streams is permitted \\
\hline & $\begin{array}{l}\text { Demonstrate Financial } \\
\text { History }\end{array}$ & $\mathrm{Y}$ \\
\hline \multirow{9}{*}{$\begin{array}{l}\text { Other Application } \\
\text { Requirements \& } \\
\text { Criteria }\end{array}$} & $\begin{array}{l}\text { Existing Plan / Strategy } \\
\text { Required }\end{array}$ & $\begin{array}{l}\text { Y; (Comprehensive Economic Development } \\
\text { Strategy (or equivalent) required) }\end{array}$ \\
\hline & $\begin{array}{l}\text { Special Requirements or } \\
\text { Benefits for Special Flood } \\
\text { Hazard Areas }\end{array}$ & $\begin{array}{l}\text { EDA evaluates all project within Special Flood } \\
\text { Hazard Areas per EDA's Floodplain Directive, EO } \\
11988 \text { and NEPA }\end{array}$ \\
\hline & $\begin{array}{l}\text { Participate / Good Standing } \\
\text { with National Flood } \\
\text { Insurance Program }\end{array}$ & $\begin{array}{l}\mathrm{N} \text { but information related to participation in the } \\
\text { National Flood Insurance Program is collected and } \\
\text { considered as part of EDA's analysis of an } \\
\text { application }\end{array}$ \\
\hline & Existing Insurance Required & $\begin{array}{l}\text { Flood Insurance required for any and all insurable } \\
\text { structures. }\end{array}$ \\
\hline & $\begin{array}{l}\text { Demonstrate NEPA } \\
\text { Compliance }\end{array}$ & $\mathrm{Y}$ \\
\hline & Public Outreach Prioritized & $\begin{array}{l}\text { Public engagement is a requirement in the } \\
\text { preparation of CEDS strategy/planning grants; } \\
\text { implementation projects funded by PW must be } \\
\text { aligned with region's CEDS. Public involvement is } \\
\text { also a requirement of NEPA for any project not } \\
\text { categorically excluded. }\end{array}$ \\
\hline & $\begin{array}{l}\text { Building Code Adoption } \\
\text { Required }\end{array}$ & NA \\
\hline & $\begin{array}{l}\text { Demonstrate Substantial } \\
\text { Damage }\end{array}$ & $\begin{array}{l}\mathrm{NA} \text { - damage is a relevant consideration but } \\
\text { "substantial damage" is not a standard used in EDA }\end{array}$ \\
\hline & Other Criteria & $\begin{array}{l}\text { Provide comments from metropolitan area } \\
\text { review/clearinghouse agency; a legal opinion and } \\
\text { other documentation, as necessary, verifying the } \\
\text { applicant's answer to questions regarding project } \\
\text { ownership, operation, maintenance, and } \\
\text { management; an engineering report. } \\
\text { See NOFO on www.eda.gov }\end{array}$ \\
\hline
\end{tabular}




\section{Environmental Protections Agency (EPA)}

\section{Clean Water State Revolving Fund}

Link to Program: https://www.epa.gov/cwsrf

Description of Program: Federal-state partnership that provides communities a permanent, independent source of low-cost financing for a wide range of water quality infrastructure projects

\begin{tabular}{|c|c|c|}
\hline & Name of Program & Clean Water State Revolving Fund \\
\hline \multirow[t]{2}{*}{ Resilience Focus } & $\begin{array}{l}\text { Resilience is a Program } \\
\text { Priority }\end{array}$ & No \\
\hline & $\begin{array}{l}\text { Mitigation, Planning, } \\
\text { Response, Recovery }\end{array}$ & Mitigation, Recovery \\
\hline \multirow[t]{3}{*}{ Program Funding } & Total Funds Available & $\begin{array}{l}\text { FY19 appropriations } \$ 6.28 \text { B. This funding includes } \\
\text { federal grant awards, state matching contributions, } \\
\text { repayments, earnings, and other sources provided } \\
\text { by the state. }\end{array}$ \\
\hline & $\begin{array}{l}\text { Funding Limitations Per } \\
\text { Application }\end{array}$ & Varies among the 51 programs \\
\hline & Cost Share Requirements & $\begin{array}{l}\text { States match federal capitalization (see additional } \\
\text { comments for more information). State loans to } \\
\text { eligible borrowers can cover } 100 \% \text { of the project } \\
\text { costs. }\end{array}$ \\
\hline \multirow[t]{2}{*}{ Funding Timing } & Application Deadlines & Varies among the $51 \mathrm{CWSRF}$ programs \\
\hline & Length of Benefit & $\begin{array}{l}\text { The CWSRFs can provide loans up to } 30 \text { years or } \\
\text { useful life, whichever is less. With EPA's approval, } \\
\text { CWSRFs can also purchase (or refinance) local debt } \\
\text { obligations over a longer repayment period. }\end{array}$ \\
\hline \multirow[t]{4}{*}{$\begin{array}{l}\text { Targeted } \\
\text { Applicants and } \\
\text { Recipients }\end{array}$} & Eligible Applicants & $\begin{array}{l}\text { States apply to EPA for the federal capitalization } \\
\text { grants. The state uses these funds to provide low } \\
\text { interest loans and other forms of assistance to } \\
\text { eligible borrowers. }\end{array}$ \\
\hline & Eligible Subapplicants & $\mathrm{N} / \mathrm{A}$ \\
\hline & Eligible Recipients & $\begin{array}{l}\text { Public utilities, state agencies, municipalities, non- } \\
\text { government organizations, tribal governments, and } \\
\text { individuals (e.g., homeowners, farmers) }\end{array}$ \\
\hline & $\begin{array}{l}\text { Low-Income, Impoverished } \\
\text { Community Status } \\
\text { Prioritized }\end{array}$ & $\begin{array}{l}\text { States may customize loans for small and } \\
\text { disadvantaged communities through additional } \\
\text { subsidization (e.g., grants, principal forgiveness, and } \\
\text { negative interest rate loans) }\end{array}$ \\
\hline \multirow[t]{3}{*}{$\begin{array}{l}\text { Hazard } \\
\text { Categorization }\end{array}$} & Hazards Included & $\begin{array}{l}\text { CWSRFs can fund projects that help } \\
\text { address/mitigate the negative impacts of natural or } \\
\text { manmade disasters. }\end{array}$ \\
\hline & $\begin{array}{l}\text { Funding for Pre-disaster } \\
\text { Activities }\end{array}$ & Yes \\
\hline & $\begin{array}{l}\text { Funding for Post-disaster } \\
\text { Activities }\end{array}$ & Yes \\
\hline \multirow[t]{2}{*}{$\begin{array}{l}\text { Disaster } \\
\text { Declaration }\end{array}$} & $\begin{array}{l}\text { Disaster Declaration } \\
\text { Required }\end{array}$ & No \\
\hline & $\begin{array}{l}\text { Unusual Circumstances } \\
\text { Accepted }\end{array}$ & No \\
\hline \multirow[t]{3}{*}{ Projects Funded } & $\begin{array}{l}\text { Type of Facility or Land } \\
\text { Funded }\end{array}$ & See additional comments for more information \\
\hline & Other Assistance Provided & See additional comments for more information \\
\hline & Project Types & See additional comments for more information \\
\hline
\end{tabular}




\begin{tabular}{|c|c|c|}
\hline \multirow[t]{3}{*}{$\begin{array}{l}\text { Financial } \\
\text { Application } \\
\text { Requirements }\end{array}$} & $\begin{array}{l}\text { Demonstrate Work is Cost } \\
\text { Effective }\end{array}$ & $\begin{array}{l}\text { All CWSRF assistance recipients meeting the } \\
\text { definition of municipality or intermunicipal, } \\
\text { interstate, or state agency must certify that they have } \\
\text { conducted a cost and effectiveness analysis. }\end{array}$ \\
\hline & $\begin{array}{l}\text { Demonstrate No Available } \\
\text { Help Found Elsewhere }\end{array}$ & $\mathrm{N} / \mathrm{A}$ \\
\hline & $\begin{array}{l}\text { Demonstrate Financial } \\
\text { History }\end{array}$ & $\begin{array}{l}\text { By statute recipients must have a dedicated source } \\
\text { of repayment for a CWSRF loan. As standard } \\
\text { practice, the CWSRF programs require recipients to } \\
\text { provide sufficient documentation to demonstrate the } \\
\text { financial capability of repaying the CWSRF and to } \\
\text { ensure that the recipient has sufficient revenues to } \\
\text { operate and maintain the project once completed. }\end{array}$ \\
\hline \multirow{10}{*}{$\begin{array}{l}\text { Other Application } \\
\text { Requirements \& } \\
\text { Criteria }\end{array}$} & $\begin{array}{l}\text { Existing Plan / Strategy } \\
\text { Required }\end{array}$ & Varies among the 51 state programs \\
\hline & $\begin{array}{l}\text { Special Requirements or } \\
\text { Benefits for Special Flood } \\
\text { Hazard Areas }\end{array}$ & \\
\hline & $\begin{array}{l}\text { Participate / Good Standing } \\
\text { with National Flood } \\
\text { Insurance Program }\end{array}$ & $\mathrm{N} / \mathrm{A}$ \\
\hline & Existing Insurance Required & N/A \\
\hline & $\begin{array}{l}\text { Demonstrate NEPA } \\
\text { Compliance }\end{array}$ & $\begin{array}{l}\text { Before receiving funding CWSRF projects } \\
\text { designated as treatment works must undergo a State } \\
\text { Environmental Review Process that is similar to } \\
\text { NEPA. }\end{array}$ \\
\hline & Public Outreach Prioritized & Varies among the 51 state programs \\
\hline & $\begin{array}{l}\text { Building Code Adoption } \\
\text { Required }\end{array}$ & No \\
\hline & $\begin{array}{l}\text { Demonstrate Substantial } \\
\text { Damage }\end{array}$ & No \\
\hline & Other Criteria & $\begin{array}{l}\text { Please consult the states' CWSRF programs for } \\
\text { information regarding additional requirements }\end{array}$ \\
\hline & Additional Comments & $\begin{array}{l}\text { The CWSRF was established by the } 1987 \\
\text { amendments to the Clean Water Act (CWA) as a } \\
\text { financial assistance program for a wide range of water } \\
\text { infrastructure projects, under } 33 \text { U.S. Code } \$ 1383 \text {. } \\
\text { The program was amended in } 2014 \text { by the Water } \\
\text { Resources Reform and Development Act. Under the } \\
\text { CWSRF, EPA provides grants to all } 50 \text { states plus } \\
\text { Puerto Rico to capitalize state CWSRF loan } \\
\text { programs. The states contribute an additional } 20 \\
\text { percent to match the federal grants. } \\
\text { The } 51 \text { CWSRF programs function like environmental } \\
\text { infrastructure banks by providing low interest loans to } \\
\text { eligible recipients for water infrastructure projects. As } \\
\text { money is paid back into the state's revolving loan } \\
\text { fund, the state makes new loans to other recipients for } \\
\text { high priority, water quality activities. Repayments of } \\
\text { loan principal and interest earnings are recycled back } \\
\text { into individual state CWSRF programs to finance new } \\
\text { projects that allow the funds to "revolve" at the state } \\
\text { level over time. } \\
\text { States are responsible for the operation of their } \\
\text { CWSRF program. States may provide various types } \\
\text { of assistance, including loans, refinancing, }\end{array}$ \\
\hline
\end{tabular}




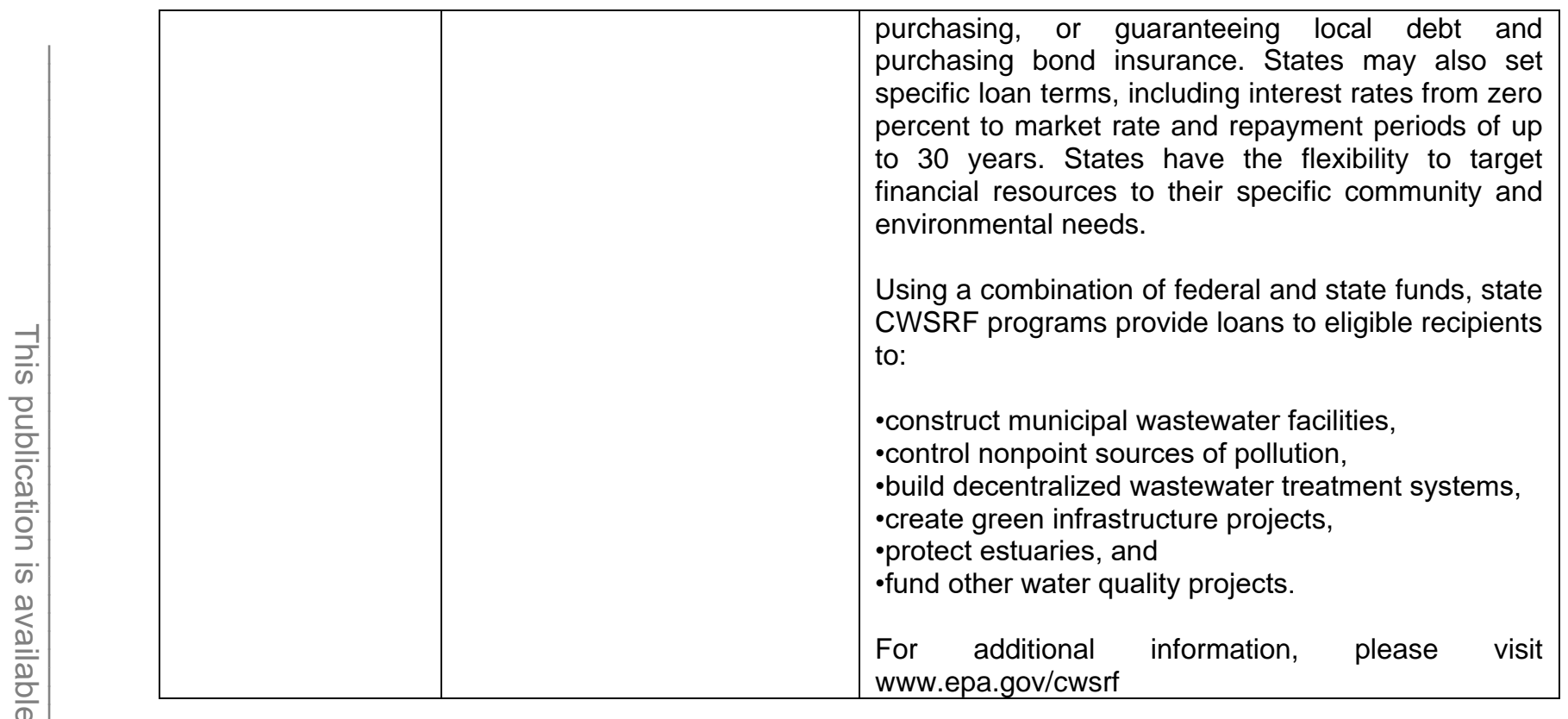




\section{Drinking Water State Revolving Fund}

Link to Program: https://www.epa.gov/dwsrf

Description of Program: Federal-state partnership to provide financial support to water systems and to state safe water programs

\begin{tabular}{|c|c|c|}
\hline & Name of Program & Drinking Water State Revolving Fund \\
\hline \multirow[t]{2}{*}{ Resilience Focus } & $\begin{array}{l}\text { Resilience is a Program } \\
\text { Priority }\end{array}$ & No \\
\hline & $\begin{array}{l}\text { Mitigation, Planning, } \\
\text { Response, Recovery }\end{array}$ & Mitigation, Recovery \\
\hline \multirow[t]{3}{*}{ Program Funding } & Total Funds Available & $\begin{array}{l}\text { Over the past 3-year ( } 2016 \text { to } 2018 \text { ), the average } \\
\text { annual amount provided to eligible borrowers was } \\
\$ 2.6 \text { billion. This funding was a result of federal } \\
\text { grant awards, state matching contributions, } \\
\text { repayments, earnings, and other sources provided } \\
\text { by the state. }\end{array}$ \\
\hline & $\begin{array}{l}\text { Funding Limitations Per } \\
\text { Application }\end{array}$ & Varies amongst the 51 state programs \\
\hline & Cost Share Requirements & $\begin{array}{l}\text { States match federal capitalization (see additional } \\
\text { comments for more information). State loans to } \\
\text { eligible borrowers can cover } 100 \% \text { of the project } \\
\text { costs; technical assistance also available }\end{array}$ \\
\hline \multirow[t]{2}{*}{ Funding Timing } & Application Deadlines & Varies amongst the 51 state programs \\
\hline & Length of Benefit & $\begin{array}{l}\text { For loans: up to } 30 \text {-year repayment max, or up to } \\
40 \text { years for state-defined "disadvantaged } \\
\text { communities", or useful life, whichever is less; with } \\
\text { EPA's approval, DWSRFs can also purchase (or } \\
\text { refinance) local debt obligations over a longer } \\
\text { repayment period; technical assistance may be } \\
\text { one-time or ongoing. }\end{array}$ \\
\hline \multirow[t]{4}{*}{$\begin{array}{l}\text { Targeted } \\
\text { Applicants and } \\
\text { Recipients }\end{array}$} & Eligible Applicants & $\begin{array}{l}\text { States apply to EPA for the federal capitalization } \\
\text { grants. The state uses these funds to provide low } \\
\text { interest loans and other forms of assistance to } \\
\text { eligible borrowers. }\end{array}$ \\
\hline & Eligible Subapplicants & $\mathrm{n} / \mathrm{a}$ \\
\hline & Eligible Recipients & $\begin{array}{l}\text { Public/Private-owned community water systems; } \\
\text { Non-profit non-community water systems }\end{array}$ \\
\hline & $\begin{array}{l}\text { Low-Income, Impoverished } \\
\text { Community Status } \\
\text { Prioritized }\end{array}$ & $\begin{array}{l}\text { States may customize loans for small and } \\
\text { disadvantaged communities through additional } \\
\text { subsidization (e.g., grants, principal forgiveness, } \\
\text { and negative interest rate loans) and extended loan } \\
\text { terms. }\end{array}$ \\
\hline \multirow[t]{3}{*}{$\begin{array}{l}\text { Hazard } \\
\text { Categorization }\end{array}$} & Hazards Included & $\begin{array}{l}\text { Ensuring the continued provision of safe drinking } \\
\text { water; DWSRFs can fund projects that help } \\
\text { address/mitigate the negative impacts of natural or } \\
\text { manmade disasters. }\end{array}$ \\
\hline & $\begin{array}{l}\text { Funding for Pre-disaster } \\
\text { Activities }\end{array}$ & Yes \\
\hline & $\begin{array}{l}\text { Funding for Post-disaster } \\
\text { Activities }\end{array}$ & Yes \\
\hline \multirow[t]{2}{*}{$\begin{array}{l}\text { Disaster } \\
\text { Declaration }\end{array}$} & $\begin{array}{l}\text { Disaster Declaration } \\
\text { Required }\end{array}$ & No \\
\hline & $\begin{array}{l}\text { Unusual Circumstances } \\
\text { Accepted }\end{array}$ & $\mathrm{N} / \mathrm{A}$ \\
\hline Projects Funded & $\begin{array}{l}\text { Type of Facility or Land } \\
\text { Funded }\end{array}$ & $\begin{array}{l}\text { Drinking water treatment facilities, pipe } \\
\text { installation/replacement, well }\end{array}$ \\
\hline
\end{tabular}




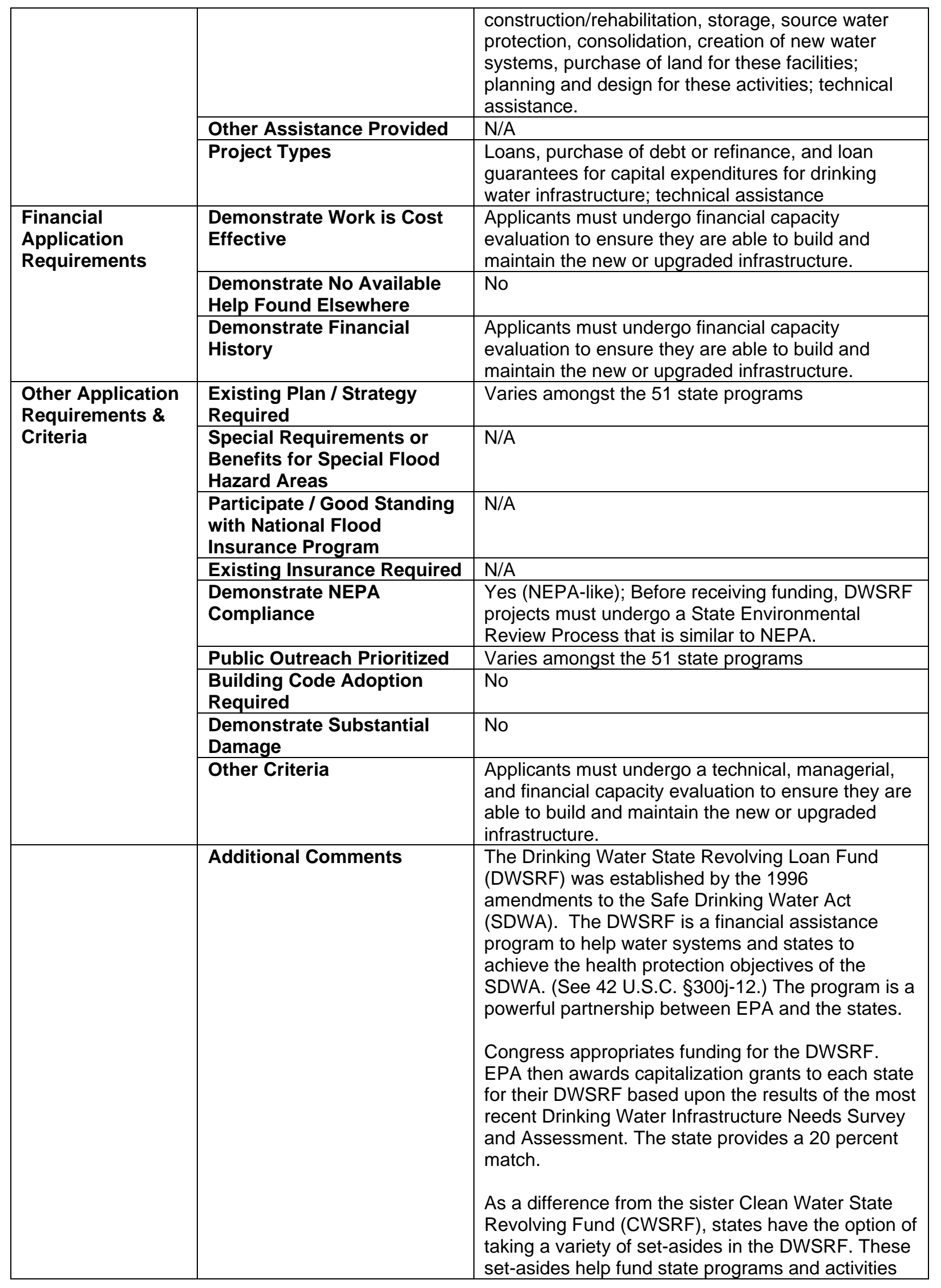




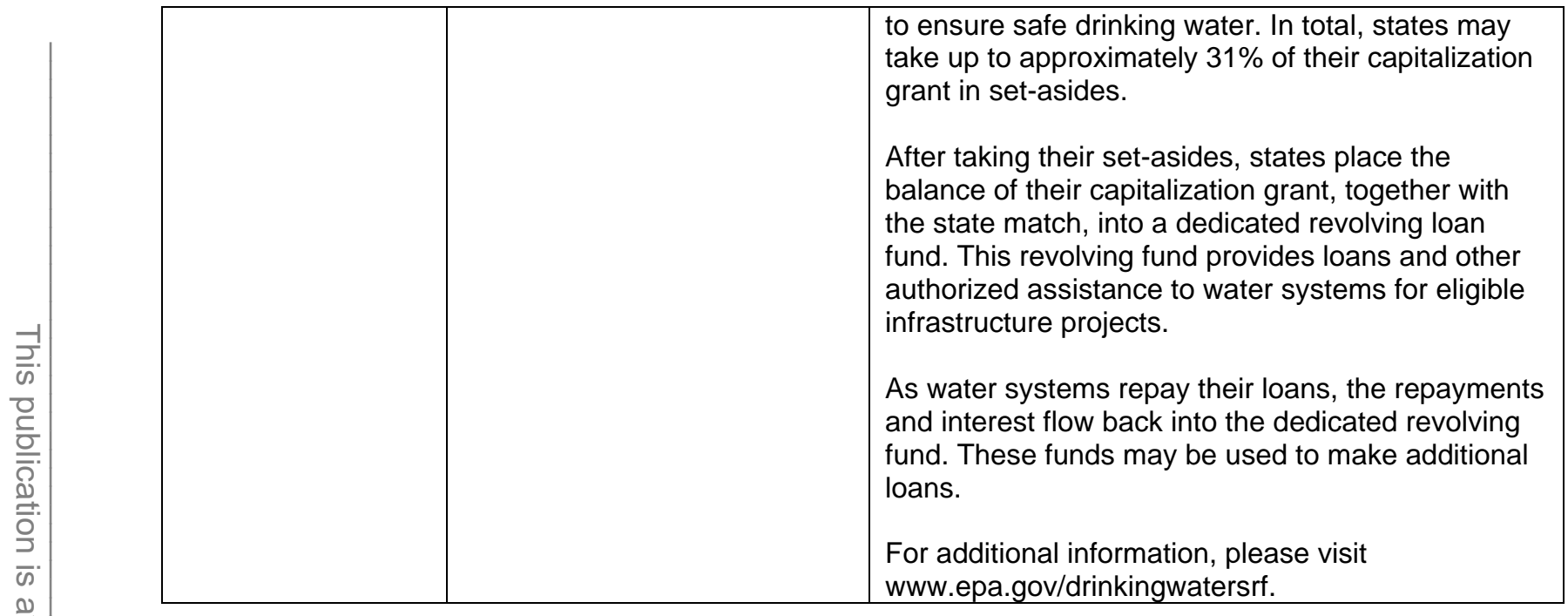




\section{Water Infrastructure Finance and Innovation Act (WIFIA)}

Link to Program: https://www.epa.gov/wifia

Description of Program: Accelerates investment in our nation's water infrastructure by providing long-term, low-cost supplemental loans for regionally and nationally significant projects.

\begin{tabular}{|c|c|c|}
\hline & Name of Program & Water Infrastructure Finance and Innovation Act \\
\hline \multirow[t]{2}{*}{ Resilience Focus } & $\begin{array}{l}\text { Resilience is a Program } \\
\text { Priority }\end{array}$ & No \\
\hline & $\begin{array}{l}\text { Mitigation, Planning, } \\
\text { Response, Recovery }\end{array}$ & Mitigation, Recovery \\
\hline \multirow[t]{3}{*}{ Program Funding } & Total Funds Available & $\begin{array}{l}\text { FY19 NOFA, } 38 \text { projects selected to apply for } \$ 6 \\
\text { billion in loans; for FY20, approximately } \$ 5 \text { billion } \\
\text { for projects in addition to } \$ 1 \text { billion for a new } \\
\text { program for State infrastructure financing } \\
\text { authorities SWIFIA: https://www.epa.gov/wifia/what- } \\
\text { swifia }\end{array}$ \\
\hline & $\begin{array}{l}\text { Funding Limitations Per } \\
\text { Application }\end{array}$ & $\begin{array}{l}\text { Minimum project size: } \$ 20 \text { million for large } \\
\text { communities; } \$ 5 \text { million for small communities } \\
(<25,000)\end{array}$ \\
\hline & Cost Share Requirements & $80 \%$ Fed cost share; $49 \%$ WIFIA fund share \\
\hline \multirow[t]{2}{*}{ Funding Timing } & Application Deadlines & One year from invitation to apply \\
\hline & Length of Benefit & $\begin{array}{l}35 \text { years: Maximum final maturity date from } \\
\text { substantial completion }\end{array}$ \\
\hline \multirow[t]{4}{*}{$\begin{array}{l}\text { Targeted } \\
\text { Applicants and } \\
\text { Recipients }\end{array}$} & Eligible Applicants & $\begin{array}{l}\text { State; Local; Tribe; Corporations; Other joint } \\
\text { programs with Water State Revolving Fund } \\
\text { Programs }\end{array}$ \\
\hline & Eligible Subapplicants & \\
\hline & Eligible Recipients & $\begin{array}{l}\text { EPA only closed in loans in large communities. } \\
\text { They are currently working with corporations and } \\
\text { small communities }\end{array}$ \\
\hline & $\begin{array}{l}\text { Low-Income, Impoverished } \\
\text { Community Status } \\
\text { Prioritized }\end{array}$ & $\begin{array}{l}\text { Selection Criteria includes The extent to which the } \\
\text { project serves economically stressed communities, } \\
\text { or pockets of economically stressed rate payers } \\
\text { within otherwise non-economically stressed } \\
\text { communities. } 40 \text { CFR } 35.10055(a)(13) \text {. }\end{array}$ \\
\hline \multirow{3}{*}{$\begin{array}{l}\text { Hazard } \\
\text { Categorization }\end{array}$} & Hazards Included & Drought \\
\hline & $\begin{array}{l}\text { Funding for Pre-disaster } \\
\text { Activities }\end{array}$ & $\mathrm{Y}$ \\
\hline & $\begin{array}{l}\text { Funding for Post-disaster } \\
\text { Activities }\end{array}$ & $\mathrm{N}$ \\
\hline \multirow[t]{2}{*}{$\begin{array}{l}\text { Disaster } \\
\text { Declaration }\end{array}$} & $\begin{array}{l}\text { Disaster Declaration } \\
\text { Required }\end{array}$ & $\mathrm{N}$ \\
\hline & $\begin{array}{l}\text { Unusual Circumstances } \\
\text { Accepted }\end{array}$ & $\mathrm{N}$ \\
\hline \multirow[t]{3}{*}{ Projects Funded } & $\begin{array}{l}\text { Type of Facility or Land } \\
\text { Funded }\end{array}$ & Public Infrastructure and Land \\
\hline & Other Assistance Provided & \\
\hline & Project Types & $\begin{array}{l}\text { Loans for drought prevention and large water } \\
\text { infrastructure projects }\end{array}$ \\
\hline \multirow{3}{*}{$\begin{array}{l}\text { Financial } \\
\text { Application } \\
\text { Requirements }\end{array}$} & $\begin{array}{l}\text { Demonstrate Work is Cost } \\
\text { Effective }\end{array}$ & $\begin{array}{l}\mathrm{Y} \text {; strength of business model and project } \\
\text { economics reviewed }\end{array}$ \\
\hline & $\begin{array}{l}\text { Demonstrate No Available } \\
\text { Help Found Elsewhere }\end{array}$ & $\mathrm{N}$ \\
\hline & $\begin{array}{l}\text { Demonstrate Financial } \\
\text { History }\end{array}$ & $\begin{array}{l}\text { Y; projects must be credit-worthy and have } \\
\text { dedicated source of revenue }\end{array}$ \\
\hline
\end{tabular}




\begin{tabular}{|c|c|c|}
\hline \multirow[t]{9}{*}{$\begin{array}{l}\text { Other Application } \\
\text { Requirements \& } \\
\text { Criteria }\end{array}$} & $\begin{array}{l}\text { Existing Plan / Strategy } \\
\text { Required }\end{array}$ & $\begin{array}{l}\text { Not required but one of the criteria is: The extent to } \\
\text { which the project addresses identified municipal, } \\
\text { state, or regional priorities. } 33 \text { U.S.C. } 3907 \text { (b)(2)(I); } \\
40 \text { CFR } 35.10055(\mathrm{a})(8) \text {. }\end{array}$ \\
\hline & $\begin{array}{l}\text { Special Requirements or } \\
\text { Benefits for Special Flood } \\
\text { Hazard Areas }\end{array}$ & $\mathrm{N}$ \\
\hline & $\begin{array}{l}\text { Participate / Good Standing } \\
\text { with National Flood } \\
\text { Insurance Program }\end{array}$ & \\
\hline & Existing Insurance Required & \\
\hline & $\begin{array}{l}\text { Demonstrate NEPA } \\
\text { Compliance }\end{array}$ & Y; NEPA applies \\
\hline & Public Outreach Prioritized & $\begin{array}{l}\text { EPA asks about community outreach in the Letter } \\
\text { of Interest }\end{array}$ \\
\hline & $\begin{array}{l}\text { Building Code Adoption } \\
\text { Required }\end{array}$ & $\mathrm{N}$ \\
\hline & $\begin{array}{l}\text { Demonstrate Substantial } \\
\text { Damage }\end{array}$ & $\mathrm{N}$ \\
\hline & Other Criteria & $\begin{array}{l}\text { FY18 NOFA, } 39 \text { projects selected to apply for } \$ 5 \\
\text { billion in loans }\end{array}$ \\
\hline
\end{tabular}




\section{FEMA}

\section{Community Disaster Loan Program}

Link to Program: https://www.fema.gov/assistance/public/nonstate-nonprofit/communitydisaster-loan

Description of Program: Provides operational funding for local governments to continue to operate after a substantial revenue loss caused by a disaster

\begin{tabular}{|c|c|c|}
\hline & Name of Program & Community Disaster Loan Program \\
\hline \multirow[t]{2}{*}{ Resilience Focus } & $\begin{array}{l}\text { Resilience is a Program } \\
\text { Priority }\end{array}$ & \\
\hline & $\begin{array}{l}\text { Mitigation, Planning, } \\
\text { Response, Recovery }\end{array}$ & Response \\
\hline \multirow[t]{3}{*}{ Program Funding } & Total Funds Available & \\
\hline & $\begin{array}{l}\text { Funding Limitations Per } \\
\text { Application }\end{array}$ & $\begin{array}{l}\text { One loan per applicant per disaster max } 5 \text { million; } \\
\text { max } 25 \% \text { of local gov annual operating budget for } \\
\text { FY of disaster; } 50 \% \text { if gov lost } 75 \% \text { or more of } \\
\text { annual operating budget }\end{array}$ \\
\hline & Cost Share Requirements & None \\
\hline \multirow[t]{2}{*}{ Funding Timing } & Application Deadlines & $\begin{array}{l}\text { Loan approval within FY of disaster or FY } \\
\text { immediately following disaster }\end{array}$ \\
\hline & Length of Benefit & 5 years \\
\hline \multirow{4}{*}{$\begin{array}{l}\text { Targeted } \\
\text { Applicants and } \\
\text { Recipients }\end{array}$} & Eligible Applicants & State \\
\hline & Eligible Subapplicants & $\mathrm{N}$ \\
\hline & Eligible Recipients & Local \\
\hline & $\begin{array}{l}\text { Low-Income, Impoverished } \\
\text { Community Status } \\
\text { Prioritized }\end{array}$ & $\mathrm{N}$ \\
\hline \multirow{3}{*}{$\begin{array}{l}\text { Hazard } \\
\text { Categorization }\end{array}$} & Hazards Included & All \\
\hline & $\begin{array}{l}\text { Funding for Pre-disaster } \\
\text { Activities }\end{array}$ & $\mathrm{N}$ \\
\hline & $\begin{array}{l}\text { Funding for Post-disaster } \\
\text { Activities }\end{array}$ & $\bar{Y}$ \\
\hline \multirow[t]{2}{*}{$\begin{array}{l}\text { Disaster } \\
\text { Declaration }\end{array}$} & $\begin{array}{l}\text { Disaster Declaration } \\
\text { Required }\end{array}$ & Y; DHS \\
\hline & $\begin{array}{l}\text { Unusual Circumstances } \\
\text { Accepted }\end{array}$ & $\mathrm{N}$ \\
\hline \multirow[t]{3}{*}{ Projects Funded } & $\begin{array}{l}\text { Type of Facility or Land } \\
\text { Funded }\end{array}$ & None \\
\hline & Other Assistance Provided & Y; local gov operations \\
\hline & Project Types & $\begin{array}{l}\text { loans to support disaster-related operations; does } \\
\text { not include repair of public facilities }\end{array}$ \\
\hline \multirow{3}{*}{$\begin{array}{l}\text { Financial } \\
\text { Application } \\
\text { Requirements }\end{array}$} & $\begin{array}{l}\text { Demonstrate Work is Cost } \\
\text { Effective }\end{array}$ & \\
\hline & $\begin{array}{l}\text { Demonstrate No Available } \\
\text { Help Found Elsewhere }\end{array}$ & $\begin{array}{l}\text { Y; limited cash availability or liquid assets from prior } \\
\text { year among others }\end{array}$ \\
\hline & $\begin{array}{l}\text { Demonstrate Financial } \\
\text { History }\end{array}$ & $\begin{array}{l}\text { Y; government must not be in arrears with respect } \\
\text { to any payments due on previous loans }\end{array}$ \\
\hline \multirow{2}{*}{$\begin{array}{l}\text { Other Application } \\
\text { Requirements \& } \\
\text { Criteria }\end{array}$} & $\begin{array}{l}\text { Existing Plan / Strategy } \\
\text { Required }\end{array}$ & \\
\hline & $\begin{array}{l}\text { Special Requirements or } \\
\text { Benefits for Special Flood } \\
\text { Hazard Areas }\end{array}$ & \\
\hline
\end{tabular}




\begin{tabular}{|c|c|c|c|}
\hline & & \multirow{2}{*}{$\begin{array}{l}\text { Participate / Good Standing } \\
\text { with National Flood } \\
\text { Insurance Program } \\
\text { Existing Insurance Required }\end{array}$} & \\
\hline & & & \\
\hline & & $\begin{array}{l}\text { Demonstrate NEPA } \\
\text { Compliance }\end{array}$ & \\
\hline & & Public Outreach Prioritized & \\
\hline & & $\begin{array}{l}\text { Building Code Adoption } \\
\text { Required }\end{array}$ & \\
\hline & & $\begin{array}{l}\text { Demonstrate Substantial } \\
\text { Damage }\end{array}$ & \\
\hline & & Other Criteria & $\begin{array}{l}\text { State law must not prohibit the local government } \\
\text { from incurring the indebtedness resulting from a } \\
\text { Federal loan. }\end{array}$ \\
\hline
\end{tabular}




\section{Community Rating System (through NFIP)}

Link to Program: https://www.fema.gov/national-flood-insurance-program-community-ratingsystem

Description of Program: Voluntary incentive program that recognizes and encourages community floodplain management activities that exceed the minimum NFIP requirements by discounting flood insurance premium rates.

\begin{tabular}{|c|c|c|}
\hline & Name of Program & Community Rating System (through NFIP) \\
\hline \multirow[t]{2}{*}{ Resilience Focus } & $\begin{array}{l}\text { Resilience is a Program } \\
\text { Priority }\end{array}$ & \\
\hline & $\begin{array}{l}\text { Mitigation, Planning, } \\
\text { Response, Recovery }\end{array}$ & Mitigation \\
\hline \multirow[t]{3}{*}{ Program Funding } & Total Funds Available & \\
\hline & $\begin{array}{l}\text { Funding Limitations Per } \\
\text { Application }\end{array}$ & Adjusted discounts by rating up to $45 \%$ \\
\hline & Cost Share Requirements & $\mathrm{N}$ \\
\hline \multirow[t]{2}{*}{ Funding Timing } & Application Deadlines & Anytime \\
\hline & Length of Benefit & Anytime \\
\hline \multirow{4}{*}{$\begin{array}{l}\text { Targeted } \\
\text { Applicants and } \\
\text { Recipients }\end{array}$} & Eligible Applicants & Local \\
\hline & Eligible Subapplicants & $\mathrm{N}$ \\
\hline & Eligible Recipients & Local \\
\hline & $\begin{array}{l}\text { Low-Income, Impoverished } \\
\text { Community Status } \\
\text { Prioritized }\end{array}$ & $\mathrm{N}$ \\
\hline \multirow{3}{*}{$\begin{array}{l}\text { Hazard } \\
\text { Categorization }\end{array}$} & Hazards Included & Flood \\
\hline & $\begin{array}{l}\text { Funding for Pre-disaster } \\
\text { Activities }\end{array}$ & $\mathrm{Y}$ \\
\hline & $\begin{array}{l}\text { Funding for Post-disaster } \\
\text { Activities }\end{array}$ & $\mathrm{N}$ \\
\hline \multirow[t]{2}{*}{$\begin{array}{l}\text { Disaster } \\
\text { Declaration }\end{array}$} & $\begin{array}{l}\text { Disaster Declaration } \\
\text { Required }\end{array}$ & $\mathrm{N}$ \\
\hline & $\begin{array}{l}\text { Unusual Circumstances } \\
\text { Accepted }\end{array}$ & $\mathrm{N}$ \\
\hline \multirow[t]{3}{*}{ Projects Funded } & $\begin{array}{l}\text { Type of Facility or Land } \\
\text { Funded }\end{array}$ & \\
\hline & Other Assistance Provided & $\mathrm{N}$ \\
\hline & Project Types & $\begin{array}{l}\text { provide SFHA residents with discounts on flood } \\
\text { insurance }\end{array}$ \\
\hline \multirow{3}{*}{$\begin{array}{l}\text { Financial } \\
\text { Application } \\
\text { Requirements }\end{array}$} & $\begin{array}{l}\text { Demonstrate Work is Cost } \\
\text { Effective }\end{array}$ & \\
\hline & $\begin{array}{l}\text { Demonstrate No Available } \\
\text { Help Found Elsewhere }\end{array}$ & \\
\hline & $\begin{array}{l}\text { Demonstrate Financial } \\
\text { History }\end{array}$ & \\
\hline \multirow{4}{*}{$\begin{array}{l}\text { Other Application } \\
\text { Requirements \& } \\
\text { Criteria }\end{array}$} & $\begin{array}{l}\text { Existing Plan / Strategy } \\
\text { Required }\end{array}$ & $\mathrm{N}$ \\
\hline & $\begin{array}{l}\text { Special Requirements or } \\
\text { Benefits for Special Flood } \\
\text { Hazard Areas }\end{array}$ & Discounts apply to SFHA residents \\
\hline & $\begin{array}{l}\text { Participate / Good Standing } \\
\text { with National Flood } \\
\text { Insurance Program }\end{array}$ & $\mathrm{Y}$ \\
\hline & Existing Insurance Required & $\mathrm{Y}$ \\
\hline
\end{tabular}




\begin{tabular}{|l|l|l|}
\hline & $\begin{array}{l}\text { Demonstrate NEPA } \\
\text { Compliance }\end{array}$ & \\
\hline & Public Outreach Prioritized & \\
\hline & Building Code Adoption & \\
& Required \\
\hline & Demonstrate Substantial & \\
& Damage & \\
\hline & Other Criteria & \\
\hline
\end{tabular}




\section{Cora Brown Fund}

Link to Program: https://www.federalgrantswire.com/cora-brown-fund.html\#.X9pdcthKiUk Description of Program: Provide for disaster-related needs that have not or will not be met by governmental agencies or any other organization that have programs to address such needs

\begin{tabular}{|c|c|c|}
\hline & Name of Program & Cora Brown Fund \\
\hline \multirow[t]{2}{*}{ Resilience Focus } & $\begin{array}{l}\text { Resilience is a Program } \\
\text { Priority }\end{array}$ & $\mathrm{N}$ \\
\hline & $\begin{array}{l}\text { Mitigation, Planning, } \\
\text { Response, Recovery }\end{array}$ & Response \\
\hline \multirow[t]{3}{*}{ Program Funding } & Total Funds Available & $\begin{array}{l}\text { Funds balance held in the Cora Brown Trust Fund } \\
\text { can be obtained through the OCFO. }\end{array}$ \\
\hline & $\begin{array}{l}\text { Funding Limitations Per } \\
\text { Application }\end{array}$ & $\$ 2,000$ per applicant per disaster \\
\hline & Cost Share Requirements & $\mathrm{N}$ \\
\hline \multirow[t]{2}{*}{ Funding Timing } & Application Deadlines & $\mathrm{N}$ \\
\hline & Length of Benefit & One-time award, if eligible \\
\hline \multirow{4}{*}{$\begin{array}{l}\text { Targeted } \\
\text { Applicants and } \\
\text { Recipients }\end{array}$} & Eligible Applicants & Individuals with disaster-related unmet needs \\
\hline & Eligible Subapplicants & $\mathrm{N}$ \\
\hline & Eligible Recipients & Individual \\
\hline & $\begin{array}{l}\text { Low-Income, Impoverished } \\
\text { Community Status } \\
\text { Prioritized }\end{array}$ & $\begin{array}{l}\text { Infrequent requests, no need for applicant } \\
\text { prioritization. }\end{array}$ \\
\hline \multirow{3}{*}{$\begin{array}{l}\text { Hazard } \\
\text { Categorization }\end{array}$} & Hazards Included & All \\
\hline & $\begin{array}{l}\text { Funding for Pre-disaster } \\
\text { Activities }\end{array}$ & $\mathrm{N}$ \\
\hline & $\begin{array}{l}\text { Funding for Post-disaster } \\
\text { Activities }\end{array}$ & $\mathrm{Y}$ \\
\hline \multirow[t]{2}{*}{$\begin{array}{l}\text { Disaster } \\
\text { Declaration }\end{array}$} & $\begin{array}{l}\text { Disaster Declaration } \\
\text { Required }\end{array}$ & $\mathrm{Y}$ \\
\hline & $\begin{array}{l}\text { Unusual Circumstances } \\
\text { Accepted }\end{array}$ & $\mathrm{N}$ \\
\hline \multirow[t]{3}{*}{ Projects Funded } & $\begin{array}{l}\text { Type of Facility or Land } \\
\text { Funded }\end{array}$ & Private \\
\hline & Other Assistance Provided & $\begin{array}{l}\text { Y; disaster-related unmet needs, other services to } \\
\text { promote wellbeing }\end{array}$ \\
\hline & Project Types & $\begin{array}{l}\text { Funding for individuals with unmet needs from a } \\
\text { disaster }\end{array}$ \\
\hline \multirow{3}{*}{$\begin{array}{l}\text { Financial } \\
\text { Application } \\
\text { Requirements }\end{array}$} & $\begin{array}{l}\text { Demonstrate Work is Cost } \\
\text { Effective }\end{array}$ & $\mathrm{N} / \mathrm{A}$ \\
\hline & $\begin{array}{l}\text { Demonstrate No Available } \\
\text { Help Found Elsewhere }\end{array}$ & $\begin{array}{l}\text { Funding will not duplicate assistance provided } \\
\text { elsewhere }\end{array}$ \\
\hline & $\begin{array}{l}\text { Demonstrate Financial } \\
\text { History }\end{array}$ & $\begin{array}{l}\text { Case Management needs to be conducted and all } \\
\text { avenues of assistance must be exhausted. }\end{array}$ \\
\hline \multirow{6}{*}{$\begin{array}{l}\text { Other Application } \\
\text { Requirements \& } \\
\text { Criteria }\end{array}$} & $\begin{array}{l}\text { Existing Plan / Strategy } \\
\text { Required }\end{array}$ & $\mathrm{N} / \mathrm{A}$ \\
\hline & $\begin{array}{l}\text { Special Requirements or } \\
\text { Benefits for Special Flood } \\
\text { Hazard Areas }\end{array}$ & $\mathrm{N} / \mathrm{A}$ \\
\hline & $\begin{array}{l}\text { Participate / Good Standing } \\
\text { with National Flood } \\
\text { Insurance Program }\end{array}$ & $\mathrm{N} / \mathrm{A}$ \\
\hline & Existing Insurance Required & $\mathrm{N} / \mathrm{A}$ \\
\hline & $\begin{array}{l}\text { Demonstrate NEPA } \\
\text { Compliance }\end{array}$ & $\mathrm{N} / \mathrm{A}$ \\
\hline & Public Outreach Prioritized & $\mathrm{N} / \mathrm{A}$ \\
\hline
\end{tabular}




\begin{tabular}{|l|l|l|}
\hline & $\begin{array}{l}\text { Building Code Adoption } \\
\text { Required }\end{array}$ & N/A \\
\cline { 2 - 3 } & $\begin{array}{l}\text { Demonstrate Substantial } \\
\text { Damage }\end{array}$ & N/A \\
\cline { 2 - 3 } & Other Criteria & $\begin{array}{l}\text { Regional director or other government agency must } \\
\text { nominate an individual }\end{array}$ \\
\hline
\end{tabular}




\section{Flood Mitigation Assistance Grant Program}

Link to Program: https://www.fema.gov/flood-mitigation-assistance-grant-program

Description of Program: Provides funding for projects and planning that reduces or eliminates long-term risk of flood damage to structures insured under the NFIP. Funding is also available for management costs.

\begin{tabular}{|c|c|c|}
\hline & Name of Program & Flood Mitigation Assistance Grant Program \\
\hline \multirow[t]{2}{*}{ Resilience Focus } & $\begin{array}{l}\text { Resilience is a Program } \\
\text { Priority }\end{array}$ & \\
\hline & $\begin{array}{l}\text { Mitigation, Planning, } \\
\text { Response, Recovery }\end{array}$ & Mitigation \\
\hline \multirow[t]{3}{*}{ Program Funding } & Total Funds Available & FY 2018 NOFO distributed \$ 160 million \\
\hline & $\begin{array}{l}\text { Funding Limitations Per } \\
\text { Application }\end{array}$ & $\begin{array}{l}\$ 10 \text { million per applicant for community mitigation } \\
\text { project; } \$ 100,000 \text { per applicant for advance } \\
\text { assistance; }<\$ 50,000 \text { for flood hazard mitigation } \\
\text { planning }\end{array}$ \\
\hline & Cost Share Requirements & $\begin{array}{l}75 \% \text { Fed cost share; } 90 \% \text { for repetitive loss } \\
\text { structures; } 100 \% \text { for severe repetitive loss } \\
\text { structures }\end{array}$ \\
\hline \multirow[t]{2}{*}{ Funding Timing } & Application Deadlines & $\begin{array}{l}\text { As determined by NOFO. FY18 Application } \\
\text { deadline } 4 \text { months post NOFO start date. }\end{array}$ \\
\hline & Length of Benefit & 42 months (FY18) \\
\hline \multirow{4}{*}{$\begin{array}{l}\text { Targeted } \\
\text { Applicants and } \\
\text { Recipients }\end{array}$} & Eligible Applicants & State; Territory; Tribe \\
\hline & Eligible Subapplicants & Local \\
\hline & Eligible Recipients & State; Tribe; Territory; \\
\hline & $\begin{array}{l}\text { Low-Income, Impoverished } \\
\text { Community Status } \\
\text { Prioritized }\end{array}$ & $\mathrm{N}$ \\
\hline \multirow{3}{*}{$\begin{array}{l}\text { Hazard } \\
\text { Categorization }\end{array}$} & Hazards Included & Flood \\
\hline & $\begin{array}{l}\text { Funding for Pre-disaster } \\
\text { Activities }\end{array}$ & $\mathrm{Y}$ \\
\hline & $\begin{array}{l}\text { Funding for Post-disaster } \\
\text { Activities }\end{array}$ & $\mathrm{N}$ \\
\hline \multirow[t]{2}{*}{$\begin{array}{l}\text { Disaster } \\
\text { Declaration }\end{array}$} & $\begin{array}{l}\text { Disaster Declaration } \\
\text { Required }\end{array}$ & $\mathrm{N}$ \\
\hline & $\begin{array}{l}\text { Unusual Circumstances } \\
\text { Accepted }\end{array}$ & $\mathrm{N}$ \\
\hline \multirow[t]{3}{*}{ Projects Funded } & $\begin{array}{l}\text { Type of Facility or Land } \\
\text { Funded }\end{array}$ & $\begin{array}{l}\text { Must have current Hazard Mitigation Plan and } \\
\text { Structures insured through NFIP }\end{array}$ \\
\hline & Other Assistance Provided & Refer to attached bi-fold for typical project types \\
\hline & Project Types & Flood natural hazard mitigation projects; planning \\
\hline \multirow{3}{*}{$\begin{array}{l}\text { Financial } \\
\text { Application } \\
\text { Requirements }\end{array}$} & $\begin{array}{l}\text { Demonstrate Work is Cost } \\
\text { Effective }\end{array}$ & Y; Benefit Cost Analysis \\
\hline & $\begin{array}{l}\text { Demonstrate No Available } \\
\text { Help Found Elsewhere }\end{array}$ & \\
\hline & $\begin{array}{l}\text { Demonstrate Financial } \\
\text { History }\end{array}$ & $\begin{array}{l}\text { Y; history of performance in managing Federal } \\
\text { award }\end{array}$ \\
\hline
\end{tabular}




\begin{tabular}{|c|c|c|}
\hline \multirow{9}{*}{$\begin{array}{l}\text { Other Application } \\
\text { Requirements \& } \\
\text { Criteria }\end{array}$} & $\begin{array}{l}\text { Existing Plan / Strategy } \\
\text { Required }\end{array}$ & Y; Hazard Mitigation Plan \\
\hline & $\begin{array}{l}\text { Special Requirements or } \\
\text { Benefits for Special Flood } \\
\text { Hazard Areas }\end{array}$ & $\begin{array}{l}\text { Community must be participating in the NFIP if } \\
\text { project is located in the SFHA; NFIP insurance } \\
\text { coverage is required for mitigation projects that } \\
\text { touch individual structures (e.g. elevations) }\end{array}$ \\
\hline & $\begin{array}{l}\text { Participate / Good Standing } \\
\text { with National Flood } \\
\text { Insurance Program }\end{array}$ & $\bar{Y}$ \\
\hline & Existing Insurance Required & Y; NFIP coverage required \\
\hline & $\begin{array}{l}\text { Demonstrate NEPA } \\
\text { Compliance }\end{array}$ & Y - EHP FEMA review \\
\hline & Public Outreach Prioritized & $\mathrm{Y}$; private partnerships cost share \\
\hline & $\begin{array}{l}\text { Building Code Adoption } \\
\text { Required }\end{array}$ & $\begin{array}{l}\text { Meet applicable state and local codes and } \\
\text { standards }\end{array}$ \\
\hline & $\begin{array}{l}\text { Demonstrate Substantial } \\
\text { Damage }\end{array}$ & $\mathrm{N}$ \\
\hline & Other Criteria & $\begin{array}{l}\text { Priority scoring criteria include building code } \\
\text { effectiveness grading schedule and cooperating } \\
\text { technical partners program participation } \\
\text { All projects are ranked on: } \\
\text { 1. Financial stability } \\
\text { 2. Quality of management systems and ability to } \\
\text { meet management standards } \\
\text { 3. History of performance in managing Federal } \\
\text { award } \\
\text { 4. Reports and findings from audits } \\
\text { 5. Ability to effectively implement statutory, } \\
\text { regulatory, or other requirements }\end{array}$ \\
\hline
\end{tabular}




\section{Fire Management Assistance Grant}

Link to Program: https://www.fema.gov/fire-management-assistance-grant-program

Description of Program: Mitigation, management, and control of fires on publicly or privately owned forests or grasslands, which threaten such destruction as would constitute a major disaster

\begin{tabular}{|c|c|c|}
\hline & Name of Program & Fire Management Assistance Grant \\
\hline \multirow[t]{2}{*}{ Resilience Focus } & $\begin{array}{l}\text { Resilience is a Program } \\
\text { Priority }\end{array}$ & \\
\hline & $\begin{array}{l}\text { Mitigation, Planning, } \\
\text { Response, Recovery }\end{array}$ & Mitigation, Recovery \\
\hline \multirow[t]{3}{*}{ Program Funding } & Total Funds Available & \\
\hline & $\begin{array}{l}\text { Funding Limitations Per } \\
\text { Application }\end{array}$ & \\
\hline & Cost Share Requirements & $\begin{array}{l}75 \% \text { Fed cost share; State funding limited to fire } \\
\text { cost threshold calculation for each state }\end{array}$ \\
\hline \multirow[t]{2}{*}{ Funding Timing } & Application Deadlines & \\
\hline & Length of Benefit & \\
\hline \multirow{4}{*}{$\begin{array}{l}\text { Targeted } \\
\text { Applicants and } \\
\text { Recipients }\end{array}$} & Eligible Applicants & State \\
\hline & Eligible Subapplicants & $\mathrm{N}$ \\
\hline & Eligible Recipients & State; Local \\
\hline & $\begin{array}{l}\text { Low-Income, Impoverished } \\
\text { Community Status } \\
\text { Prioritized }\end{array}$ & \\
\hline \multirow{3}{*}{$\begin{array}{l}\text { Hazard } \\
\text { Categorization }\end{array}$} & Hazards Included & Fire \\
\hline & $\begin{array}{l}\text { Funding for Pre-disaster } \\
\text { Activities }\end{array}$ & $\mathrm{Y}$ \\
\hline & $\begin{array}{l}\text { Funding for Post-disaster } \\
\text { Activities }\end{array}$ & $\mathrm{N}$ \\
\hline \multirow[t]{2}{*}{$\begin{array}{l}\text { Disaster } \\
\text { Declaration }\end{array}$} & $\begin{array}{l}\text { Disaster Declaration } \\
\text { Required }\end{array}$ & Y; Threat submitted by State to FEMA \\
\hline & $\begin{array}{l}\text { Unusual Circumstances } \\
\text { Accepted }\end{array}$ & $\mathrm{N}$ \\
\hline \multirow[t]{3}{*}{ Projects Funded } & $\begin{array}{l}\text { Type of Facility or Land } \\
\text { Funded }\end{array}$ & Public and private land \\
\hline & Other Assistance Provided & $\begin{array}{l}\text { Y; field camps, mobilization, demobilization of } \\
\text { firefighters, equipment }\end{array}$ \\
\hline & Project Types & funding for fire mitigation and control \\
\hline \multirow{3}{*}{$\begin{array}{l}\text { Financial } \\
\text { Application } \\
\text { Requirements }\end{array}$} & $\begin{array}{l}\text { Demonstrate Work is Cost } \\
\text { Effective }\end{array}$ & \\
\hline & $\begin{array}{l}\text { Demonstrate No Available } \\
\text { Help Found Elsewhere }\end{array}$ & $\begin{array}{l}\text { Availability of State and local firefighting resources } \\
\text { assessed }\end{array}$ \\
\hline & $\begin{array}{l}\text { Demonstrate Financial } \\
\text { History }\end{array}$ & \\
\hline \multirow{6}{*}{$\begin{array}{l}\text { Other Application } \\
\text { Requirements \& } \\
\text { Criteria }\end{array}$} & $\begin{array}{l}\text { Existing Plan / Strategy } \\
\text { Required }\end{array}$ & \\
\hline & $\begin{array}{l}\text { Special Requirements or } \\
\text { Benefits for Special Flood } \\
\text { Hazard Areas }\end{array}$ & \\
\hline & $\begin{array}{l}\text { Participate / Good Standing } \\
\text { with National Flood } \\
\text { Insurance Program }\end{array}$ & \\
\hline & Existing Insurance Required & \\
\hline & $\begin{array}{l}\text { Demonstrate NEPA } \\
\text { Compliance }\end{array}$ & \\
\hline & Public Outreach Prioritized & \\
\hline
\end{tabular}




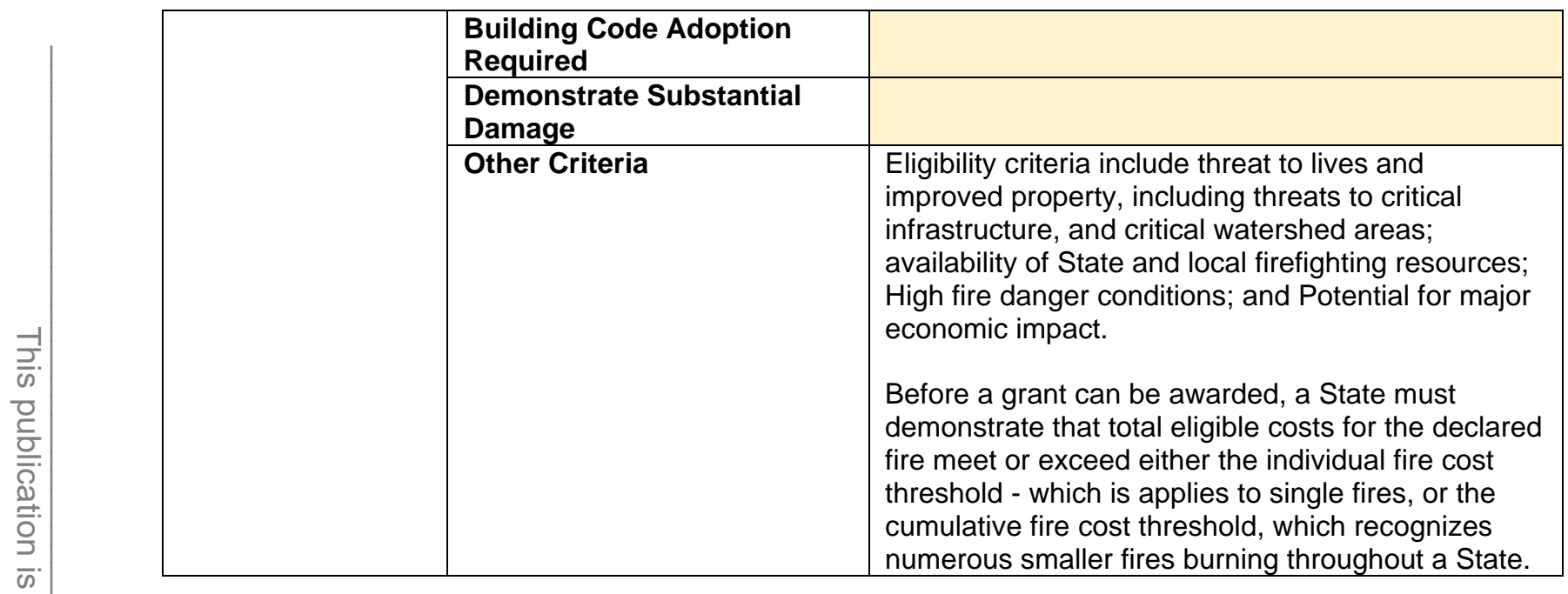




\section{Hazard Mitigation Grant Program}

Link to Program: https://www.fema.gov/hazard-mitigation-grant-program

Description of Program: Help communities implement hazard mitigation measures to reduce risk of loss of life and property from future disasters after a Presidential Disaster Declaration

\begin{tabular}{|c|c|c|}
\hline & Name of Program & Hazard Mitigation Grant Program \\
\hline \multirow[t]{2}{*}{ Resilience Focus } & $\begin{array}{l}\text { Resilience is a Program } \\
\text { Priority }\end{array}$ & \\
\hline & $\begin{array}{l}\text { Mitigation, Planning, } \\
\text { Response, Recovery }\end{array}$ & Mitigation, Recovery \\
\hline \multirow[t]{3}{*}{ Program Funding } & Total Funds Available & Calculated as $15-20 \%$ of major disaster declaration. \\
\hline & $\begin{array}{l}\text { Funding Limitations Per } \\
\text { Application }\end{array}$ & $\begin{array}{l}\text { None. Applicant must demonstrate cost- } \\
\text { effectiveness. }\end{array}$ \\
\hline & Cost Share Requirements & $\begin{array}{l}75 \% \text { cost share for the entire HMGP award. Each } \\
\text { individual sub-award may have a higher or lower } \\
\text { cost-share as long as the cost-share across the } \\
\text { HMGP award is not greater than } 75 \% \text { federal }\end{array}$ \\
\hline \multirow[t]{2}{*}{ Funding Timing } & Application Deadlines & 12 months post disaster declaration \\
\hline & Length of Benefit & \\
\hline \multirow{4}{*}{$\begin{array}{l}\text { Targeted } \\
\text { Applicants and } \\
\text { Recipients }\end{array}$} & Eligible Applicants & State; Tribe; Territory \\
\hline & Eligible Subapplicants & Local; PNPs \\
\hline & Eligible Recipients & State; Tribe; Territory; \\
\hline & $\begin{array}{l}\text { Low-Income, Impoverished } \\
\text { Community Status } \\
\text { Prioritized }\end{array}$ & $\mathrm{N}$ \\
\hline \multirow{3}{*}{$\begin{array}{l}\text { Hazard } \\
\text { Categorization }\end{array}$} & Hazards Included & All \\
\hline & $\begin{array}{l}\text { Funding for Pre-disaster } \\
\text { Activities }\end{array}$ & $\mathrm{N}$ \\
\hline & $\begin{array}{l}\text { Funding for Post-disaster } \\
\text { Activities }\end{array}$ & $\mathrm{Y}$ \\
\hline \multirow[t]{2}{*}{$\begin{array}{l}\text { Disaster } \\
\text { Declaration }\end{array}$} & $\begin{array}{l}\text { Disaster Declaration } \\
\text { Required }\end{array}$ & $\mathrm{Y}$ \\
\hline & $\begin{array}{l}\text { Unusual Circumstances } \\
\text { Accepted }\end{array}$ & $\mathrm{N}$ \\
\hline \multirow[t]{3}{*}{ Projects Funded } & $\begin{array}{l}\text { Type of Facility or Land } \\
\text { Funded }\end{array}$ & Must have current Hazard Mitigation Plan \\
\hline & Other Assistance Provided & Refer to attached bi-fold for typical project types \\
\hline & Project Types & $\begin{array}{l}\text { All natural hazard mitigation projects; generators for } \\
\text { critical facilities; planning }\end{array}$ \\
\hline \multirow{4}{*}{$\begin{array}{l}\text { Financial } \\
\text { Application } \\
\text { Requirements }\end{array}$} & $\begin{array}{l}\text { Demonstrate Work is Cost } \\
\text { Effective }\end{array}$ & Y; Benefit Cost Analysis \\
\hline & $\begin{array}{l}\text { Demonstrate No Available } \\
\text { Help Found Elsewhere }\end{array}$ & \\
\hline & $\begin{array}{l}\text { Demonstrate Financial } \\
\text { History }\end{array}$ & $\begin{array}{l}\text { Y; history of performance in managing Federal } \\
\text { award }\end{array}$ \\
\hline & $\begin{array}{l}\text { Existing Plan / Strategy } \\
\text { Required }\end{array}$ & Y; Hazard Mitigation Plan \\
\hline
\end{tabular}




\begin{tabular}{|l|l|l|}
\hline $\begin{array}{l}\text { Other Application } \\
\text { Requirements \& } \\
\text { Criteria }\end{array}$ & $\begin{array}{l}\text { Special Requirements or } \\
\text { Benefits for Special Flood } \\
\text { Hazard Areas }\end{array}$ & $\begin{array}{l}\text { Community must be participating in the NFIP if } \\
\text { project is located in the SFHA }\end{array}$ \\
\cline { 2 - 3 } & $\begin{array}{l}\text { Participate / Good Standing } \\
\text { with National Flood } \\
\text { Insurance Program }\end{array}$ & Y for SFHA \\
\cline { 2 - 3 } & Existing Insurance Required & N \\
\cline { 2 - 3 } & $\begin{array}{l}\text { Demonstrate NEPA } \\
\text { Compliance }\end{array}$ & Y - EHP FEMA review \\
\cline { 2 - 3 } & $\begin{array}{l}\text { Public Outreach Prioritized } \\
\text { Building Code Adoption } \\
\text { Required }\end{array}$ & N \\
\cline { 2 - 3 } & $\begin{array}{l}\text { Demonstrate Substantial International 2009 or newer } \\
\text { Damage }\end{array}$ & N \\
\cline { 2 - 3 } & $\begin{array}{l}\text { Other Criteria } \\
\text { Pthojects must also: } \\
\text { Benefit the disaster area } \\
\text { Solve a problem and be technically feasible } \\
\text { Consider a range of alternatives }\end{array}$ \\
\hline
\end{tabular}




\section{Increased Cost of Compliance (through NFIP)}

Link to Program: https://www.fema.gov/floodplain-management/financial-help/increased-costcompliance

Description of Program: Helps NFIP policyholders with the costs incurred if they are required by the community building department to meet rebuilding standards after a flood. Provides up to $\$ 30,000$ to help pay for relocating, elevating, demolishing, and floodproofing (non-residential buildings), or any combination of these mitigation activities

\begin{tabular}{|c|c|c|}
\hline & Name of Program & Increased Cost of Compliance (through NFIP) \\
\hline \multirow[t]{2}{*}{ Resilience Focus } & $\begin{array}{l}\text { Resilience is a Program } \\
\text { Priority }\end{array}$ & \\
\hline & $\begin{array}{l}\text { Mitigation, Planning, } \\
\text { Response, Recovery }\end{array}$ & Recovery \\
\hline \multirow[t]{3}{*}{ Program Funding } & Total Funds Available & \\
\hline & $\begin{array}{l}\text { Funding Limitations Per } \\
\text { Application }\end{array}$ & $\$ 30,000$ per applicant \\
\hline & Cost Share Requirements & $\begin{array}{l}\text { ICC funds count as non-Fed matching funds for } \\
\text { other mitigation grants }\end{array}$ \\
\hline \multirow[t]{2}{*}{ Funding Timing } & Application Deadlines & $\begin{array}{l}60 \text { days to submit to ICC Proof of Loss after } \\
\text { receiving letter from insurance carrier }\end{array}$ \\
\hline & Length of Benefit & 6 years to date after flood loss \\
\hline \multirow{4}{*}{$\begin{array}{l}\text { Targeted } \\
\text { Applicants and } \\
\text { Recipients }\end{array}$} & Eligible Applicants & Homeowner; Building Owner \\
\hline & Eligible Subapplicants & $\mathrm{N}$ \\
\hline & Eligible Recipients & Homeowner; Building Owner \\
\hline & $\begin{array}{l}\text { Low-Income, Impoverished } \\
\text { Community Status } \\
\text { Prioritized }\end{array}$ & \\
\hline \multirow{3}{*}{$\begin{array}{l}\text { Hazard } \\
\text { Categorization }\end{array}$} & Hazards Included & Flood \\
\hline & $\begin{array}{l}\text { Funding for Pre-disaster } \\
\text { Activities }\end{array}$ & $\mathrm{N}$ \\
\hline & $\begin{array}{l}\text { Funding for Post-disaster } \\
\text { Activities }\end{array}$ & $\bar{Y}$ \\
\hline \multirow[t]{2}{*}{$\begin{array}{l}\text { Disaster } \\
\text { Declaration }\end{array}$} & $\begin{array}{l}\text { Disaster Declaration } \\
\text { Required }\end{array}$ & $\mathrm{N}$ \\
\hline & $\begin{array}{l}\text { Unusual Circumstances } \\
\text { Accepted }\end{array}$ & $\mathrm{N}$ \\
\hline \multirow[t]{3}{*}{ Projects Funded } & $\begin{array}{l}\text { Type of Facility or Land } \\
\text { Funded }\end{array}$ & Structures insured through NFIP \\
\hline & Other Assistance Provided & $\mathrm{N}$ \\
\hline & Project Types & $\begin{array}{l}\text { Funding to help bring buildings in compliance with } \\
\text { flood ordinances }\end{array}$ \\
\hline \multirow{3}{*}{$\begin{array}{l}\text { Financial } \\
\text { Application } \\
\text { Requirements }\end{array}$} & $\begin{array}{l}\text { Demonstrate Work is Cost } \\
\text { Effective }\end{array}$ & \\
\hline & $\begin{array}{l}\text { Demonstrate No Available } \\
\text { Help Found Elsewhere }\end{array}$ & $\mathrm{N}$ \\
\hline & $\begin{array}{l}\text { Demonstrate Financial } \\
\text { History }\end{array}$ & \\
\hline \multirow{2}{*}{$\begin{array}{l}\text { Other Application } \\
\text { Requirements \& } \\
\text { Criteria }\end{array}$} & $\begin{array}{l}\text { Existing Plan / Strategy } \\
\text { Required }\end{array}$ & $\mathrm{N}$ \\
\hline & $\begin{array}{l}\text { Special Requirements or } \\
\text { Benefits for Special Flood } \\
\text { Hazard Areas }\end{array}$ & Building must be located in an SFHA \\
\hline
\end{tabular}




\begin{tabular}{|c|c|c|c|}
\hline & $\begin{array}{l}\text { Participate / Good Standing } \\
\text { with National Flood } \\
\text { Insurance Program }\end{array}$ & $\bar{Y}$ \\
\hline & & Existing Insurance Required & $\mathrm{Y}$ \\
\hline & & $\begin{array}{l}\text { Demonstrate NEPA } \\
\text { Compliance }\end{array}$ & \\
\hline & & Public Outreach Prioritized & \\
\hline & & $\begin{array}{l}\text { Building Code Adoption } \\
\text { Required }\end{array}$ & $\mathrm{Y}$ \\
\hline & & $\begin{array}{l}\text { Demonstrate Substantial } \\
\text { Damage }\end{array}$ & $\mathrm{Y}$ or structure is a repetitive loss structure \\
\hline & & Other Criteria & Provide proof of occupancy \\
\hline
\end{tabular}




\section{Individual Assistance Programs}

Link to Program: https://www.fema.gov/assistance/individual

Description of Program: Ensure disaster survivors have timely access to a full range of authorized programs and services to maximize recovery, through partnered coordination of local, state, territorial, and Indian Tribal governments, as well as other Federal agencies, nongovernmental organizations and the private sector. Individual Assistance Programs include: Mass Care and Emergency Assistance (MC/EA), Crisis Counseling Assistance and Training Program (CCP), Disaster Unemployment Assistance (DUA) through the Department of Labor, Disaster Legal Services (DLS), Disaster Case Management (DCM), and Individuals and Households Program (IHP).

\begin{tabular}{|c|c|c|}
\hline & Name of Program & Individual Assistance Programs \\
\hline \multirow[t]{2}{*}{ Resilience Focus } & $\begin{array}{l}\text { Resilience is a Program } \\
\text { Priority }\end{array}$ & 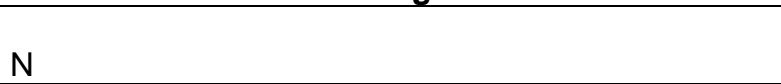 \\
\hline & $\begin{array}{l}\text { Mitigation, Planning, } \\
\text { Response, Recovery }\end{array}$ & Recovery \\
\hline \multirow[t]{3}{*}{ Program Funding } & Total Funds Available & Varies by disaster declaration \\
\hline & $\begin{array}{l}\text { Funding Limitations Per } \\
\text { Application }\end{array}$ & $\$ 34,900$ for IHP per applicant \\
\hline & Cost Share Requirements & $\mathrm{N} / \mathrm{A}$ \\
\hline \multirow[t]{2}{*}{ Funding Timing } & Application Deadlines & $\mathrm{N} / \mathrm{A}$ \\
\hline & Length of Benefit & $\begin{array}{l}18 \text { months following the date of the disaster } \\
\text { declaration and may be extended due to } \\
\text { extraordinary circumstances }\end{array}$ \\
\hline \multirow{4}{*}{$\begin{array}{l}\text { Targeted } \\
\text { Applicants and } \\
\text { Recipients }\end{array}$} & Eligible Applicants & U.S. citizen, non-citizen national, or qualified alien \\
\hline & Eligible Subapplicants & $\mathrm{N}$ \\
\hline & Eligible Recipients & U.S. citizen, non-citizen national, or qualified alien \\
\hline & $\begin{array}{l}\text { Low-Income, Impoverished } \\
\text { Community Status } \\
\text { Prioritized }\end{array}$ & \\
\hline \multirow{3}{*}{$\begin{array}{l}\text { Hazard } \\
\text { Categorization }\end{array}$} & Hazards Included & All \\
\hline & $\begin{array}{l}\text { Funding for Pre-disaster } \\
\text { Activities }\end{array}$ & $\mathrm{N}$ \\
\hline & $\begin{array}{l}\text { Funding for Post-disaster } \\
\text { Activities }\end{array}$ & $\bar{Y}$ \\
\hline \multirow[t]{2}{*}{$\begin{array}{l}\text { Disaster } \\
\text { Declaration }\end{array}$} & $\begin{array}{l}\text { Disaster Declaration } \\
\text { Required }\end{array}$ & $\bar{Y}$ \\
\hline & $\begin{array}{l}\text { Unusual Circumstances } \\
\text { Accepted }\end{array}$ & $\mathrm{N}$ \\
\hline \multirow[t]{4}{*}{ Projects Funded } & $\begin{array}{l}\text { Type of Facility or Land } \\
\text { Funded }\end{array}$ & Housing \\
\hline & Other Assistance Provided & $\mathrm{Y}$ \\
\hline & Project Types & $\begin{array}{l}\text { Home repair and replacement assistance; } \\
\text { uninsured or underinsured necessary expenses and } \\
\text { serious } \\
\text { needs }\end{array}$ \\
\hline & $\begin{array}{l}\text { Demonstrate Work is Cost } \\
\text { Effective }\end{array}$ & \\
\hline
\end{tabular}




\begin{tabular}{|c|c|c|}
\hline \multirow{2}{*}{$\begin{array}{l}\text { Financial } \\
\text { Application } \\
\text { Requirements }\end{array}$} & $\begin{array}{l}\text { Demonstrate No Available } \\
\text { Help Found Elsewhere }\end{array}$ & $\mathrm{Y}$ \\
\hline & $\begin{array}{l}\text { Demonstrate Financial } \\
\text { History }\end{array}$ & \\
\hline \multirow{9}{*}{$\begin{array}{l}\text { Other Application } \\
\text { Requirements \& } \\
\text { Criteria }\end{array}$} & $\begin{array}{l}\text { Existing Plan / Strategy } \\
\text { Required }\end{array}$ & $\mathrm{N}$ \\
\hline & $\begin{array}{l}\text { Special Requirements or } \\
\text { Benefits for Special Flood } \\
\text { Hazard Areas }\end{array}$ & $\mathrm{N}$ \\
\hline & $\begin{array}{l}\text { Participate / Good Standing } \\
\text { with National Flood } \\
\text { Insurance Program }\end{array}$ & $\mathrm{N}$ \\
\hline & Existing Insurance Required & $\begin{array}{l}\mathrm{N} ; \mathrm{IHP} \text { is not a substitute for insurance and cannot } \\
\text { compensate for all losses caused by a } \\
\text { disaster; it is intended to meet the survivor's basic } \\
\text { needs and supplement disaster recovery } \\
\text { efforts. }\end{array}$ \\
\hline & $\begin{array}{l}\text { Demonstrate NEPA } \\
\text { Compliance }\end{array}$ & \\
\hline & Public Outreach Prioritized & \\
\hline & $\begin{array}{l}\text { Building Code Adoption } \\
\text { Required }\end{array}$ & $\mathrm{N}$ \\
\hline & $\begin{array}{l}\text { Demonstrate Substantial } \\
\text { Damage }\end{array}$ & Depends on assistance type provided \\
\hline & Other Criteria & $\begin{array}{l}\text { Provide proof of identity; insurance or other forms of } \\
\text { assistance cannot meet disaster-caused needs; } \\
\text { necessary expenses and needs directly caused by } \\
\text { a declared disaster. }\end{array}$ \\
\hline
\end{tabular}




\section{Individuals and Households Program}

Link to Program: https://www.fema.gov/assistance/individual/program

Description of Program: Provides financial assistance and direct services to eligible individuals and households who have uninsured or underinsured necessary expenses and serious needs.

\begin{tabular}{|c|c|c|}
\hline & Name of Program & Individuals and Households Program \\
\hline \multirow[t]{2}{*}{ Resilience Focus } & $\begin{array}{l}\text { Resilience is a Program } \\
\text { Priority }\end{array}$ & No \\
\hline & $\begin{array}{l}\text { Mitigation, Planning, } \\
\text { Response, Recovery }\end{array}$ & Response \\
\hline \multirow[t]{3}{*}{ Program Funding } & Total Funds Available & \\
\hline & $\begin{array}{l}\text { Funding Limitations Per } \\
\text { Application }\end{array}$ & $\begin{array}{l}{ }^{*} \text { FY20 Financial Housing Assistance Maximum: } \\
\$ 35,500 \text {. } \\
{ }^{*} \text { FY20 Other Needs Assistance Maximum: } \$ 35,500 \text {. } \\
\text { (*No financial assistance maximum for Temporary } \\
\text { Housing Assistance including Lodging Expense } \\
\text { Reimbursement, Rental Assistance, and Continued } \\
\text { Temporary Housing Assistance) }\end{array}$ \\
\hline & Cost Share Requirements & $\begin{array}{l}{ }^{*} 100 \% \text { Housing Assistance; }{ }^{*} 75 \% \text { of Other Needs } \\
\text { Assistance and Transitional Sheltering Assistance; } \\
\text { the state, territorial, or tribal government is } \\
\text { responsible for the remaining } 25 \% \text {. }\end{array}$ \\
\hline \multirow[t]{2}{*}{ Funding Timing } & Application Deadlines & $\begin{array}{l}60 \text { days from the date of the major disaster } \\
\text { declaration. }\end{array}$ \\
\hline & Length of Benefit & $\begin{array}{l}18 \text { months following the date of the major disaster } \\
\text { declaration }\end{array}$ \\
\hline \multirow[t]{4}{*}{$\begin{array}{l}\text { Targeted } \\
\text { Applicants and } \\
\text { Recipients }\end{array}$} & Eligible Applicants & $\begin{array}{l}\text { Individuals and households who have uninsured or } \\
\text { underinsured necessary expenses and serious } \\
\text { needs as a result of a major disaster. }\end{array}$ \\
\hline & Eligible Subapplicants & $\mathrm{N}$ \\
\hline & Eligible Recipients & Individual; Homeowner, Renter Primary Residence \\
\hline & $\begin{array}{l}\text { Low-Income, Impoverished } \\
\text { Community Status } \\
\text { Prioritized }\end{array}$ & $\mathrm{N} / \mathrm{A}$ \\
\hline \multirow{3}{*}{$\begin{array}{l}\text { Hazard } \\
\text { Categorization }\end{array}$} & Hazards Included & Determined by Presidential disaster declaration \\
\hline & $\begin{array}{l}\text { Funding for Pre-disaster } \\
\text { Activities }\end{array}$ & $\mathrm{N}$ \\
\hline & $\begin{array}{l}\text { Funding for Post-disaster } \\
\text { Activities }\end{array}$ & $\mathrm{Y}$ \\
\hline \multirow[t]{2}{*}{$\begin{array}{l}\text { Disaster } \\
\text { Declaration }\end{array}$} & $\begin{array}{l}\text { Disaster Declaration } \\
\text { Required }\end{array}$ & Y \\
\hline & $\begin{array}{l}\text { Unusual Circumstances } \\
\text { Accepted }\end{array}$ & $\begin{array}{l}\text { Although rare, IHP assistance may be made } \\
\text { available under emergency declarations. }\end{array}$ \\
\hline \multirow[t]{4}{*}{ Projects Funded } & $\begin{array}{l}\text { Type of Facility or Land } \\
\text { Funded }\end{array}$ & The applicant's pre-disaster, primary residence. \\
\hline & Other Assistance Provided & $\begin{array}{l}\text { Temporary Housing Assistance, to include Lodging } \\
\text { Expense Reimbursement, Rental Assistance, and } \\
\text { Continued Temporary Housing Assistance. }\end{array}$ \\
\hline & Project Types & $\begin{array}{l}\text { Financial Housing Assistance, Direct Temporary } \\
\text { Housing Assistance, Permanent Housing } \\
\text { Construction }\end{array}$ \\
\hline & $\begin{array}{l}\text { Demonstrate Work is Cost } \\
\text { Effective }\end{array}$ & \\
\hline
\end{tabular}




\begin{tabular}{|c|c|c|}
\hline \multirow[t]{2}{*}{$\begin{array}{l}\text { Financial } \\
\text { Application } \\
\text { Requirements }\end{array}$} & $\begin{array}{l}\text { Demonstrate No Available } \\
\text { Help Found Elsewhere }\end{array}$ & $\begin{array}{l}\text { FEMA may provide IHP assistance to applicants for } \\
\text { their uninsured and underinsured disaster-caused } \\
\text { expenses and serious needs. }\end{array}$ \\
\hline & $\begin{array}{l}\text { Demonstrate Financial } \\
\text { History }\end{array}$ & \\
\hline \multirow[t]{9}{*}{$\begin{array}{l}\text { Other Application } \\
\text { Requirements \& } \\
\text { Criteria }\end{array}$} & $\begin{array}{l}\text { Existing Plan / Strategy } \\
\text { Required }\end{array}$ & $\begin{array}{l}\text { Applicants who receive Continued Temporary } \\
\text { Housing Assistance must demonstrate that they are } \\
\text { working toward achieving a permanent housing } \\
\text { plan. }\end{array}$ \\
\hline & $\begin{array}{l}\text { Special Requirements or } \\
\text { Benefits for Special Flood } \\
\text { Hazard Areas }\end{array}$ & Y; SFHA must have flood insurance \\
\hline & $\begin{array}{l}\text { Participate / Good Standing } \\
\text { with National Flood } \\
\text { Insurance Program }\end{array}$ & $\begin{array}{l}\text { Y; Applicants who do not obtain and maintain flood } \\
\text { insurance will be ineligible for IHP assistance for } \\
\text { flood-damaged real or personal property in future } \\
\text { disasters with flood-related damage. }\end{array}$ \\
\hline & Existing Insurance Required & Flood for SFHA \\
\hline & $\begin{array}{l}\text { Demonstrate NEPA } \\
\text { Compliance }\end{array}$ & $\begin{array}{l}\text { Environmental Planning and Historic Preservation } \\
\text { (EHP) review required for certain types of IHP } \\
\text { assistance. }\end{array}$ \\
\hline & Public Outreach Prioritized & $\mathrm{N} / \mathrm{A}$ \\
\hline & $\begin{array}{l}\text { Building Code Adoption } \\
\text { Required }\end{array}$ & $\mathrm{N} / \mathrm{A}$ \\
\hline & $\begin{array}{l}\text { Demonstrate Substantial } \\
\text { Damage }\end{array}$ & Habitability repairs required for Housing Assistance. \\
\hline & Other Criteria & $\begin{array}{l}\text { General IHP Eligibility: must be a U.S. citizen, non- } \\
\text { citizen national, or qualified alien; must be able to } \\
\text { verify identity, insurance or other forms of disaster } \\
\text { assistance received cannot meet the disaster- } \\
\text { caused needs, necessary expenses and serious } \\
\text { needs are directly caused by declared disaster. } \\
\text { For some forms of Housing Assistance and Other } \\
\text { Needs Assistance, applicants must prove } \\
\text { occupancy and/or ownership. }\end{array}$ \\
\hline
\end{tabular}




\section{Pre-Disaster Mitigation Grant Program}

Link to Program: https://www.fema.gov/pre-disaster-mitigation-grant-program

Description of Program: Assist communities in implementing a sustained pre-disaster natural hazard mitigation program. Funds awarded to planning and project grants.

\begin{tabular}{|c|c|c|}
\hline & Name of Program & Pre-Disaster Mitigation Grant Program \\
\hline \multirow[t]{2}{*}{ Resilience Focus } & $\begin{array}{l}\text { Resilience is a Program } \\
\text { Priority }\end{array}$ & \\
\hline & $\begin{array}{l}\text { Mitigation, Planning, } \\
\text { Response, Recovery }\end{array}$ & Mitigation, Planning \\
\hline \multirow[t]{3}{*}{ Program Funding } & Total Funds Available & FY 2018 NOFO distributed $\$ 235,200,000$ \\
\hline & $\begin{array}{l}\text { Funding Limitations Per } \\
\text { Application }\end{array}$ & $\begin{array}{l}\text { No applicant may receive more than } 15 \% \text {, or } \\
\$ 37,380,000 \text {, of the appropriated funds (Stafford Act } \\
203(f)(2)) ; \$ 15 \text { million for Tribes, max } \$ 575,000 \text { per } \\
\text { tribe }\end{array}$ \\
\hline & Cost Share Requirements & $\begin{array}{l}75 \% \text { Fed cost share; } 90 \% \text { for small impoverished } \\
\text { communities; specific budgets per project activity } \\
\text { e.g., } 4 \text { million Fed share for mitigation }\end{array}$ \\
\hline \multirow[t]{2}{*}{ Funding Timing } & Application Deadlines & $\begin{array}{l}\text { As determined by NOFO. FY18 Application } \\
\text { deadline } 4 \text { months post NOFO start date. }\end{array}$ \\
\hline & Length of Benefit & $\begin{array}{l}42 \text { months, } 54 \text { months for infrastructure projects } \\
\text { (FY18) }\end{array}$ \\
\hline \multirow{4}{*}{$\begin{array}{l}\text { Targeted } \\
\text { Applicants and } \\
\text { Recipients }\end{array}$} & Eligible Applicants & State; Tribe; Territory \\
\hline & Eligible Subapplicants & Local \\
\hline & Eligible Recipients & State; Tribe; Territory; \\
\hline & $\begin{array}{l}\text { Low-Income, Impoverished } \\
\text { Community Status } \\
\text { Prioritized }\end{array}$ & Y; increased cost-share and prioritization \\
\hline \multirow{3}{*}{$\begin{array}{l}\text { Hazard } \\
\text { Categorization }\end{array}$} & Hazards Included & All \\
\hline & $\begin{array}{l}\text { Funding for Pre-disaster } \\
\text { Activities }\end{array}$ & $\mathrm{Y}$ \\
\hline & $\begin{array}{l}\text { Funding for Post-disaster } \\
\text { Activities }\end{array}$ & $\mathrm{N}$ \\
\hline \multirow[t]{2}{*}{$\begin{array}{l}\text { Disaster } \\
\text { Declaration }\end{array}$} & $\begin{array}{l}\text { Disaster Declaration } \\
\text { Required }\end{array}$ & $\mathrm{N}$ \\
\hline & $\begin{array}{l}\text { Unusual Circumstances } \\
\text { Accepted }\end{array}$ & $\mathrm{N}$ \\
\hline \multirow[t]{3}{*}{ Projects Funded } & $\begin{array}{l}\text { Type of Facility or Land } \\
\text { Funded }\end{array}$ & Must have current Hazard Mitigation Plan \\
\hline & Other Assistance Provided & Refer to attached bi-fold for typical project types \\
\hline & Project Types & $\begin{array}{l}\text { All natural hazard mitigation projects; generators for } \\
\text { critical facilities; planning }\end{array}$ \\
\hline \multirow{3}{*}{$\begin{array}{l}\text { Financial } \\
\text { Application } \\
\text { Requirements }\end{array}$} & $\begin{array}{l}\text { Demonstrate Work is Cost } \\
\text { Effective }\end{array}$ & Y; Benefit Cost Analysis \\
\hline & $\begin{array}{l}\text { Demonstrate No Available } \\
\text { Help Found Elsewhere }\end{array}$ & \\
\hline & $\begin{array}{l}\text { Demonstrate Financial } \\
\text { History }\end{array}$ & $\begin{array}{l}\text { Y; history of performance in managing Federal } \\
\text { award }\end{array}$ \\
\hline
\end{tabular}




\begin{tabular}{|c|c|c|}
\hline \multirow{9}{*}{$\begin{array}{l}\text { Other Application } \\
\text { Requirements \& } \\
\text { Criteria }\end{array}$} & $\begin{array}{l}\text { Existing Plan / Strategy } \\
\text { Required }\end{array}$ & Y; Hazard Mitigation Plan \\
\hline & $\begin{array}{l}\text { Special Requirements or } \\
\text { Benefits for Special Flood } \\
\text { Hazard Areas }\end{array}$ & $\begin{array}{l}\text { Community must be participating in the NFIP if } \\
\text { project is located in the SFHA }\end{array}$ \\
\hline & $\begin{array}{l}\text { Participate / Good Standing } \\
\text { with National Flood } \\
\text { Insurance Program }\end{array}$ & $\begin{array}{l}\text { Y for SFHA, NFIP Community Rating System } \\
\text { participation prioritized }\end{array}$ \\
\hline & Existing Insurance Required & $\mathrm{N}$ \\
\hline & $\begin{array}{l}\text { Demonstrate NEPA } \\
\text { Compliance }\end{array}$ & Y; EHP FEMA review \\
\hline & Public Outreach Prioritized & Y; private-partnership cost share \\
\hline & $\begin{array}{l}\text { Building Code Adoption } \\
\text { Required }\end{array}$ & Y; International 2009 or newer \\
\hline & $\begin{array}{l}\text { Demonstrate Substantial } \\
\text { Damage }\end{array}$ & $\mathrm{N}$ \\
\hline & Other Criteria & $\begin{array}{l}\text { Priority scoring criteria include building code } \\
\text { effectiveness grading schedule and cooperating } \\
\text { technical partners program participation } \\
\text { All projects are ranked on: } \\
\text { 1. Financial stability } \\
\text { 2. Quality of management systems and ability to } \\
\text { meet management standards } \\
\text { 3. History of performance in managing Federal } \\
\text { award } \\
\text { 4. Reports and findings from audits } \\
\text { 5. Ability to effectively implement statutory, } \\
\text { regulatory, or other requirements } \\
\text { Participation in FireWise USA Program is prioritized }\end{array}$ \\
\hline
\end{tabular}




\section{Public Assistance Grant}

Link to Program: https://www.fema.gov/public-assistance-local-state-tribal-and-non-profit

Description of Program: support communities' recovery from major disasters by providing them with grant assistance for debris removal, life-saving emergency protective measures, and restoring public infrastructure

\begin{tabular}{|c|c|c|}
\hline & Name of Program & Public Assistance Grant \\
\hline \multirow[t]{2}{*}{ Resilience Focus } & $\begin{array}{l}\text { Resilience is a Program } \\
\text { Priority }\end{array}$ & \\
\hline & $\begin{array}{l}\text { Mitigation, Planning, } \\
\text { Response, Recovery }\end{array}$ & Response \\
\hline \multirow[t]{3}{*}{ Program Funding } & Total Funds Available & \\
\hline & $\begin{array}{l}\text { Funding Limitations Per } \\
\text { Application }\end{array}$ & \\
\hline & Cost Share Requirements & Determined by Presidential disaster declaration \\
\hline \multirow[t]{2}{*}{ Funding Timing } & Application Deadlines & $\begin{array}{l}30 \text { days post disaster declaration; report damages } \\
\text { within } 60 \text { days of regulatory timeframe }\end{array}$ \\
\hline & Length of Benefit & \\
\hline \multirow{4}{*}{$\begin{array}{l}\text { Targeted } \\
\text { Applicants and } \\
\text { Recipients }\end{array}$} & Eligible Applicants & State; Tribal; Territory; Local ; PNP \\
\hline & Eligible Subapplicants & $\mathrm{N}$ \\
\hline & Eligible Recipients & State; Tribal; Territory; Local ; PNP \\
\hline & $\begin{array}{l}\text { Low-Income, Impoverished } \\
\text { Community Status } \\
\text { Prioritized }\end{array}$ & \\
\hline \multirow{3}{*}{$\begin{array}{l}\text { Hazard } \\
\text { Categorization }\end{array}$} & Hazards Included & Determined by Presidential disaster declaration \\
\hline & $\begin{array}{l}\text { Funding for Pre-disaster } \\
\text { Activities }\end{array}$ & $\mathrm{N}$ \\
\hline & $\begin{array}{l}\text { Funding for Post-disaster } \\
\text { Activities }\end{array}$ & $\bar{Y}$ \\
\hline \multirow[t]{2}{*}{$\begin{array}{l}\text { Disaster } \\
\text { Declaration }\end{array}$} & $\begin{array}{l}\text { Disaster Declaration } \\
\text { Required }\end{array}$ & $\mathrm{Y}$ \\
\hline & $\begin{array}{l}\text { Unusual Circumstances } \\
\text { Accepted }\end{array}$ & $\mathrm{N}$ \\
\hline \multirow[t]{3}{*}{ Projects Funded } & $\begin{array}{l}\text { Type of Facility or Land } \\
\text { Funded }\end{array}$ & $\begin{array}{l}\text { Public, PNP Facilities that provide critical or } \\
\text { essential gov service }\end{array}$ \\
\hline & Other Assistance Provided & Y; debris removal, emergency protective service \\
\hline & Project Types & $\begin{array}{l}\text { emergency protective service/debris removal/facility } \\
\text { repair/facility restoration }\end{array}$ \\
\hline \multirow{3}{*}{$\begin{array}{l}\text { Financial } \\
\text { Application } \\
\text { Requirements }\end{array}$} & $\begin{array}{l}\text { Demonstrate Work is Cost } \\
\text { Effective }\end{array}$ & $\bar{Y}$ \\
\hline & $\begin{array}{l}\text { Demonstrate No Available } \\
\text { Help Found Elsewhere }\end{array}$ & \\
\hline & $\begin{array}{l}\text { Demonstrate Financial } \\
\text { History }\end{array}$ & \\
\hline \multirow{5}{*}{$\begin{array}{l}\text { Other Application } \\
\text { Requirements \& } \\
\text { Criteria }\end{array}$} & $\begin{array}{l}\text { Existing Plan / Strategy } \\
\text { Required }\end{array}$ & \\
\hline & $\begin{array}{l}\text { Special Requirements or } \\
\text { Benefits for Special Flood } \\
\text { Hazard Areas }\end{array}$ & \\
\hline & $\begin{array}{l}\text { Participate / Good Standing } \\
\text { with National Flood } \\
\text { Insurance Program }\end{array}$ & \\
\hline & Existing Insurance Required & \\
\hline & $\begin{array}{l}\text { Demonstrate NEPA } \\
\text { Compliance }\end{array}$ & Y; EHP review undertaken by FEMA \\
\hline
\end{tabular}




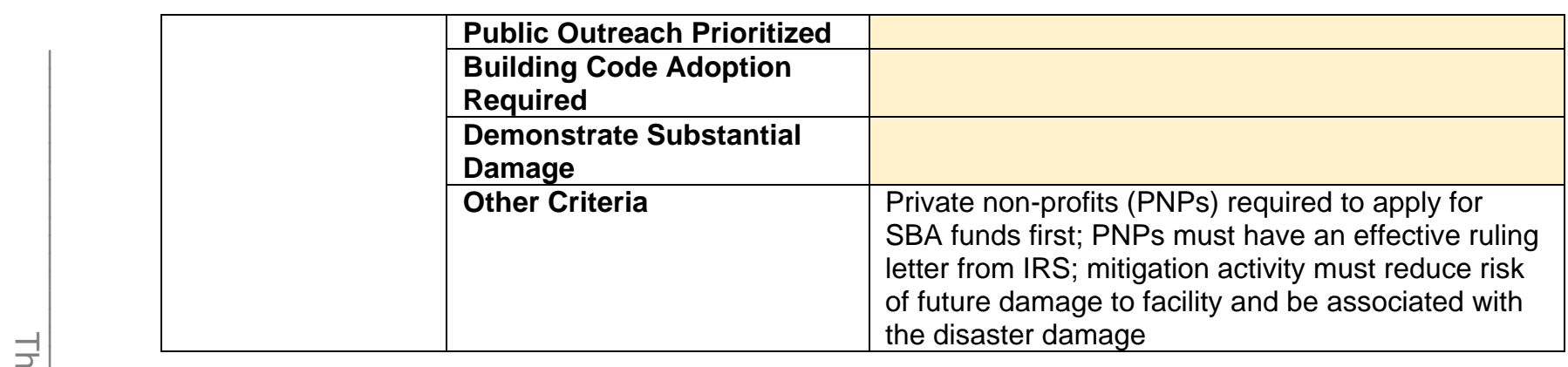




\section{Department of Housing and Urban Development (HUD)}

\section{Community Development Block Grant (CDBG)}

Link to Program:

https://www.hud.gov/program_offices/comm_planning/communitydevelopment/programs

Description of Program: Flexible program that provides communities with resources to address a wide range of unique community development needs. Provides annual grants on a formula basis to 1209 general units of local government and states to ensure decent affordable housing, to provide services to the most vulnerable in our communities, and to create jobs through the expansion and retention of businesses.

\begin{tabular}{|c|c|c|}
\hline & Name of Program & Community Development Block Grant (CDBG) \\
\hline \multirow[t]{2}{*}{ Resilience Focus } & $\begin{array}{l}\text { Resilience is a Program } \\
\text { Priority }\end{array}$ & \\
\hline & $\begin{array}{l}\text { Mitigation, Planning, } \\
\text { Response, Recovery }\end{array}$ & Mitigation, Recovery \\
\hline \multirow[t]{3}{*}{ Program Funding } & Total Funds Available & \\
\hline & $\begin{array}{l}\text { Funding Limitations Per } \\
\text { Application }\end{array}$ & \\
\hline & Cost Share Requirements & \\
\hline \multirow{2}{*}{ Funding Timing } & Application Deadlines & \\
\hline & Length of Benefit & \\
\hline \multirow{4}{*}{$\begin{array}{l}\text { Targeted } \\
\text { Applicants and } \\
\text { Recipients }\end{array}$} & Eligible Applicants & State; Local \\
\hline & Eligible Subapplicants & $\mathrm{N} / \mathrm{A}$ \\
\hline & Eligible Recipients & State; Local; Tribes \\
\hline & $\begin{array}{l}\text { Low-Income, Impoverished } \\
\text { Community Status } \\
\text { Prioritized }\end{array}$ & $\begin{array}{l}\text { Y; } 70 \% \text { of CDBG funds must benefit lo-mod income } \\
\text { persons. }\end{array}$ \\
\hline \multirow{3}{*}{$\begin{array}{l}\text { Hazard } \\
\text { Categorization }\end{array}$} & Hazards Included & All \\
\hline & $\begin{array}{l}\text { Funding for Pre-disaster } \\
\text { Activities }\end{array}$ & $\begin{array}{l}\text { Y; planning is an eligible activity if a grantee } \\
\text { chooses. }\end{array}$ \\
\hline & $\begin{array}{l}\text { Funding for Post-disaster } \\
\text { Activities }\end{array}$ & $\begin{array}{l}\text { Y; if a grantee chooses to re-program its grant } \\
\text { funds. }\end{array}$ \\
\hline \multirow[t]{2}{*}{$\begin{array}{l}\text { Disaster } \\
\text { Declaration }\end{array}$} & $\begin{array}{l}\text { Disaster Declaration } \\
\text { Required }\end{array}$ & \\
\hline & $\begin{array}{l}\text { Unusual Circumstances } \\
\text { Accepted }\end{array}$ & \\
\hline \multirow[t]{3}{*}{ Projects Funded } & $\begin{array}{l}\text { Type of Facility or Land } \\
\text { Funded }\end{array}$ & Public or private business/home/facility \\
\hline & Other Assistance Provided & $\begin{array}{l}\text { Infrastructure; economic development; public } \\
\text { services }\end{array}$ \\
\hline & Project Types & $\begin{array}{l}\text { Wide range of housing, economic development, } \\
\text { public improvements/facilities, public services, } \\
\text { planning. }\end{array}$ \\
\hline \multirow{4}{*}{$\begin{array}{l}\text { Financial } \\
\text { Application } \\
\text { Requirements }\end{array}$} & $\begin{array}{l}\text { Demonstrate Work is Cost } \\
\text { Effective }\end{array}$ & $\begin{array}{l}\text { Y - Post award records establish necessary and } \\
\text { reasonable costs. }\end{array}$ \\
\hline & $\begin{array}{l}\text { Demonstrate No Available } \\
\text { Help Found Elsewhere }\end{array}$ & For some activities, must not supplant other funds. \\
\hline & $\begin{array}{l}\text { Demonstrate Financial } \\
\text { History }\end{array}$ & \\
\hline & $\begin{array}{l}\text { Existing Plan / Strategy } \\
\text { Required }\end{array}$ & \\
\hline
\end{tabular}




\begin{tabular}{|c|c|c|}
\hline \multirow[t]{9}{*}{$\begin{array}{l}\text { Other Application } \\
\text { Requirements \& } \\
\text { Criteria }\end{array}$} & $\begin{array}{l}\text { Special Requirements or } \\
\text { Benefits for Special Flood } \\
\text { Hazard Areas }\end{array}$ & $\begin{array}{l}\text { Federal official NEPA and other environmental } \\
\text { review role is delegated to grantees who are } \\
\text { responsible for floodplain requirements. Grantee } \\
\text { certifies that it will comply with all applicable laws. }\end{array}$ \\
\hline & $\begin{array}{l}\text { Participate / Good Standing } \\
\text { with National Flood } \\
\text { Insurance Program }\end{array}$ & \\
\hline & Existing Insurance Required & \\
\hline & $\begin{array}{l}\text { Demonstrate NEPA } \\
\text { Compliance }\end{array}$ & $\begin{array}{l}\text { Not in application. HUD reviews grantee records on } \\
\text { site. }\end{array}$ \\
\hline & Public Outreach Prioritized & Y; Citizen participation plan \\
\hline & $\begin{array}{l}\text { Building Code Adoption } \\
\text { Required }\end{array}$ & $\mathrm{N}$ \\
\hline & $\begin{array}{l}\text { Demonstrate Substantial } \\
\text { Damage }\end{array}$ & $\mathrm{N}$ \\
\hline & Other Criteria & $\begin{array}{l}\text { Develop Consolidated ( } 5 \text { year) and annual action } \\
\text { plans }\end{array}$ \\
\hline & Additional Comments & \\
\hline
\end{tabular}




\section{CDBG - Disaster Recovery}

Link to Program: https://www.hud.gov/hudprograms/disaster-recovery

Description of Program: Helps communities and neighborhoods that otherwise might not recover due to limits on other resources. Disaster Recovery grants supplement disaster programs of the Federal Emergency Management Agency (FEMA), the Small Business Administration, and the U.S. Army Corps of Engineers.

\begin{tabular}{|c|c|c|}
\hline & Name of Program & CDBG - Disaster Recovery \\
\hline \multirow[t]{2}{*}{ Resilience Focus } & $\begin{array}{l}\text { Resilience is a Program } \\
\text { Priority }\end{array}$ & $\mathrm{Y}$ \\
\hline & $\begin{array}{l}\text { Mitigation, Planning, } \\
\text { Response, Recovery }\end{array}$ & Recovery \\
\hline \multirow[t]{3}{*}{ Program Funding } & Total Funds Available & $\begin{array}{l}\text { FY17 } \$ 7.4 \text { Billion; Program does not receive an } \\
\text { annual allocation based on a formula; The amount } \\
\text { is dependent on Congress allocating funds for the } \\
\text { unmet needs of a presidentially declared disaster. }\end{array}$ \\
\hline & $\begin{array}{l}\text { Funding Limitations Per } \\
\text { Application }\end{array}$ & \\
\hline & Cost Share Requirements & \\
\hline \multirow{2}{*}{ Funding Timing } & Application Deadlines & \\
\hline & Length of Benefit & \\
\hline \multirow{4}{*}{$\begin{array}{l}\text { Targeted } \\
\text { Applicants and } \\
\text { Recipients }\end{array}$} & Eligible Applicants & State; Local; US Territories; Tribes \\
\hline & Eligible Subapplicants & $\mathrm{N} / \mathrm{A}$ \\
\hline & Eligible Recipients & State; Local; , sometimes Tribes \\
\hline & $\begin{array}{l}\text { Low-Income, Impoverished } \\
\text { Community Status } \\
\text { Prioritized }\end{array}$ & $\begin{array}{l}\text { Y; usually } 70 \% \text { of overall grant but may be waived } \\
\text { lower. }\end{array}$ \\
\hline \multirow{3}{*}{$\begin{array}{l}\text { Hazard } \\
\text { Categorization }\end{array}$} & Hazards Included & All \\
\hline & $\begin{array}{l}\text { Funding for Pre-disaster } \\
\text { Activities }\end{array}$ & $\mathrm{N}$ \\
\hline & $\begin{array}{l}\text { Funding for Post-disaster } \\
\text { Activities }\end{array}$ & $\mathrm{Y}$ \\
\hline \multirow[t]{2}{*}{$\begin{array}{l}\text { Disaster } \\
\text { Declaration }\end{array}$} & $\begin{array}{l}\text { Disaster Declaration } \\
\text { Required }\end{array}$ & $\mathrm{Y}$ \\
\hline & $\begin{array}{l}\text { Unusual Circumstances } \\
\text { Accepted }\end{array}$ & $\mathrm{N}$ \\
\hline \multirow[t]{3}{*}{ Projects Funded } & $\begin{array}{l}\text { Type of Facility or Land } \\
\text { Funded }\end{array}$ & Public or private business/home/facility \\
\hline & Other Assistance Provided & $\begin{array}{l}\text { Infrastructure, economic development; public } \\
\text { services }\end{array}$ \\
\hline & Project Types & $\begin{array}{l}\text { Wide range of housing, economic development, } \\
\text { public improvements/facilities, public services, } \\
\text { planning. }\end{array}$ \\
\hline \multirow{4}{*}{$\begin{array}{l}\text { Financial } \\
\text { Application } \\
\text { Requirements }\end{array}$} & $\begin{array}{l}\text { Demonstrate Work is Cost } \\
\text { Effective }\end{array}$ & $\begin{array}{l}\text { Y; Post award records establish necessary and } \\
\text { reasonable costs. }\end{array}$ \\
\hline & $\begin{array}{l}\text { Demonstrate No Available } \\
\text { Help Found Elsewhere }\end{array}$ & $\begin{array}{l}\text { HUD encourages grantees to have } \\
\text { homeowners/businesses apply for FEMA and SBA } \\
\text { loans first. Funds may not duplicate other public or } \\
\text { federal assistance. }\end{array}$ \\
\hline & $\begin{array}{l}\text { Demonstrate Financial } \\
\text { History }\end{array}$ & $\begin{array}{l}\text { Grantees must have proficient financial controls and } \\
\text { procurement processes in place. }\end{array}$ \\
\hline & $\begin{array}{l}\text { Existing Plan / Strategy } \\
\text { Required }\end{array}$ & $\begin{array}{l}\mathrm{N} ; \text { An Action Plan is needed following the } \\
\text { allocation. }\end{array}$ \\
\hline
\end{tabular}




\begin{tabular}{|c|c|c|}
\hline \multirow[t]{9}{*}{$\begin{array}{l}\text { Other Application } \\
\text { Requirements \& } \\
\text { Criteria }\end{array}$} & $\begin{array}{l}\text { Special Requirements or } \\
\text { Benefits for Special Flood } \\
\text { Hazard Areas }\end{array}$ & $\begin{array}{l}\text { Y; Same as CDBG plus additional grantee } \\
\text { certification about using most recent floodplain } \\
\text { data; ABFE+2 for some appropriations. }\end{array}$ \\
\hline & $\begin{array}{l}\text { Participate / Good Standing } \\
\text { with National Flood } \\
\text { Insurance Program }\end{array}$ & $\begin{array}{l}\text { Requirements for insurance participation are } \\
\text { specific to allocations. }\end{array}$ \\
\hline & Existing Insurance Required & $\begin{array}{l}\text { Requirements for insurance participation are } \\
\text { specific to allocations. }\end{array}$ \\
\hline & $\begin{array}{l}\text { Demonstrate NEPA } \\
\text { Compliance }\end{array}$ & Same as CDBG. \\
\hline & Public Outreach Prioritized & Y; Citizen participation plan needed. \\
\hline & $\begin{array}{l}\text { Building Code Adoption } \\
\text { Required }\end{array}$ & \\
\hline & $\begin{array}{l}\text { Demonstrate Substantial } \\
\text { Damage }\end{array}$ & $\begin{array}{l}\text { Applicable State, local, and tribal codes and } \\
\text { standards for floodplain management that exceed } \\
\text { the requirements, including elevation, setbacks, and } \\
\text { cumulative substantial damage requirements, must } \\
\text { be followed. }\end{array}$ \\
\hline & Other Criteria & \\
\hline & Additional Comments & \\
\hline
\end{tabular}




\section{CDBG - Mitigation}

Link to Program:

https://www.hud.gov/press/press_releases_media_advisories/HUD_No_19_129

Description of Program: A unique and significant opportunity for grantees to use this assistance in areas impacted by recent disasters to carry out long-term strategic and high-impact activities to mitigate disaster risks and reduce future losses. While it is impossible to eliminate all risks, these funds will enable grantees to mitigate against disaster risks, while at the same time allowing grantees the opportunity to transform State and local planning.

\begin{tabular}{|c|c|c|}
\hline & Name of Program & CDBG - Mitigation \\
\hline \multirow[t]{2}{*}{ Resilience Focus } & $\begin{array}{l}\text { Resilience is a Program } \\
\text { Priority }\end{array}$ & $\mathrm{Y}$ \\
\hline & $\begin{array}{l}\text { Mitigation, Planning, } \\
\text { Response, Recovery }\end{array}$ & Mitigation, Recovery \\
\hline \multirow[t]{3}{*}{ Program Funding } & Total Funds Available & $\begin{array}{l}2019 \text { notice: } \$ 6.875 \text { billion in Community } \\
\text { Development Block Grant Mitigation (CDBG-MIT) } \\
\text { funds to grantees recovering from qualifying } 2015 \text {, } \\
2016 \text {, and } 2017 \text { disasters. Program does not } \\
\text { receive an annual allocation based on a formula. } \\
\text { The amount is dependent on Congress allocating } \\
\text { funds to reduce future risk for affected communities. }\end{array}$ \\
\hline & $\begin{array}{l}\text { Funding Limitations Per } \\
\text { Application }\end{array}$ & \\
\hline & Cost Share Requirements & \\
\hline \multirow[t]{2}{*}{ Funding Timing } & Application Deadlines & \\
\hline & Length of Benefit & \\
\hline \multirow{4}{*}{$\begin{array}{l}\text { Targeted } \\
\text { Applicants and } \\
\text { Recipients }\end{array}$} & Eligible Applicants & State \\
\hline & Eligible Subapplicants & \\
\hline & Eligible Recipients & State; Local; Tribes; US Territories \\
\hline & $\begin{array}{l}\text { Low-Income, Impoverished } \\
\text { Community Status } \\
\text { Prioritized }\end{array}$ & $\mathrm{Y} ; 50 \%$ of overall grant, but may be waived lower. \\
\hline \multirow{3}{*}{$\begin{array}{l}\text { Hazard } \\
\text { Categorization }\end{array}$} & Hazards Included & All \\
\hline & $\begin{array}{l}\text { Funding for Pre-disaster } \\
\text { Activities }\end{array}$ & $\mathrm{N}$ \\
\hline & $\begin{array}{l}\text { Funding for Post-disaster } \\
\text { Activities }\end{array}$ & $\mathrm{Y}$ \\
\hline \multirow[t]{2}{*}{$\begin{array}{l}\text { Disaster } \\
\text { Declaration }\end{array}$} & $\begin{array}{l}\text { Disaster Declaration } \\
\text { Required }\end{array}$ & $\begin{array}{l}\mathrm{N} ; \text { A CDBG-MIT allocation requires a CDBG-DR } \\
\text { grant, which can only be awarded after a disaster } \\
\text { declaration. }\end{array}$ \\
\hline & $\begin{array}{l}\text { Unusual Circumstances } \\
\text { Accepted }\end{array}$ & \\
\hline \multirow[t]{3}{*}{ Projects Funded } & $\begin{array}{l}\text { Type of Facility or Land } \\
\text { Funded }\end{array}$ & Public or private business/home/facility. \\
\hline & Other Assistance Provided & $\begin{array}{l}\text { Infrastructure, economic development; public } \\
\text { services }\end{array}$ \\
\hline & Project Types & $\begin{array}{l}\text { Wide range of housing, economic development, } \\
\text { public improvements/facilities, public services, } \\
\text { planning. }\end{array}$ \\
\hline \multirow{2}{*}{$\begin{array}{l}\text { Financial } \\
\text { Application } \\
\text { Requirements }\end{array}$} & $\begin{array}{l}\text { Demonstrate Work is Cost } \\
\text { Effective }\end{array}$ & $\mathrm{Y}$ \\
\hline & $\begin{array}{l}\text { Demonstrate No Available } \\
\text { Help Found Elsewhere }\end{array}$ & $\begin{array}{l}\mathrm{N} \text {; Funds may not duplicate other public or federal } \\
\text { assistance. }\end{array}$ \\
\hline
\end{tabular}




\begin{tabular}{|c|c|c|}
\hline & $\begin{array}{l}\text { Demonstrate Financial } \\
\text { History }\end{array}$ & \\
\hline \multirow[t]{10}{*}{$\begin{array}{l}\text { Other Application } \\
\text { Requirements \& } \\
\text { Criteria }\end{array}$} & $\begin{array}{l}\text { Existing Plan / Strategy } \\
\text { Required }\end{array}$ & $\begin{array}{l}\text { Y; The grantee must describe how it plans to: } \\
\text { Promote local and regional long-term planning and } \\
\text { implementation informed by its Mitigation Needs } \\
\text { Assessment, including through the development } \\
\text { and enforcement of building codes and standards } \\
\text { (such as wildland urban interface; and flood and all } \\
\text { hazards, including ASCE-24 and ASCE-7, as may } \\
\text { be applicable), vertical flood elevation protection, } \\
\text { and revised land use and zoning policies; } \\
\text { coordinate with other planning efforts by local and } \\
\text { regional entities to ensure alignment of CDBG-MIT } \\
\text { activities with those plans; and support actions to } \\
\text { promote an increase in hazard insurance coverage. } \\
\text { In addition, grantees are encouraged to use CDBG- } \\
\text { MIT planning funds to update the FEMA-approved } \\
\text { Hazard Mitigation Plans (HMP) and are required to } \\
\text { reference the applicable FEMA HMP in their action } \\
\text { plan and describe how the HMP has informed the } \\
\text { CDBG-MIT action plan. They also have to } \\
\text { coordinate and align these CDBG-MIT funds with } \\
\text { mitigation projects funded by FEMA, USACE, and } \\
\text { other agencies. }\end{array}$ \\
\hline & $\begin{array}{l}\text { Special Requirements or } \\
\text { Benefits for Special Flood } \\
\text { Hazard Areas }\end{array}$ & $\begin{array}{l}\text { For grantees addressing flood risks, the grantee } \\
\text { must describe how it will document its decision to } \\
\text { elevate structures and how it evaluated and } \\
\text { determined the elevation to be cost reasonable } \\
\text { relative to other alternatives or strategies, such as } \\
\text { the demolition of substantially damaged structures } \\
\text { with reconstruction of an elevated structure on the } \\
\text { same site, property buyouts, or infrastructure } \\
\text { improvements to reduce the risk of loss of life and } \\
\text { property. }\end{array}$ \\
\hline & $\begin{array}{l}\text { Participate / Good Standing } \\
\text { with National Flood } \\
\text { Insurance Program }\end{array}$ & $\begin{array}{l}\text { Requirements for insurance participation are } \\
\text { specific to allocations. }\end{array}$ \\
\hline & Existing Insurance Required & \\
\hline & $\begin{array}{l}\text { Demonstrate NEPA } \\
\text { Compliance }\end{array}$ & \\
\hline & Public Outreach Prioritized & Y; Citizen participation plan needed. \\
\hline & $\begin{array}{l}\text { Building Code Adoption } \\
\text { Required }\end{array}$ & \\
\hline & $\begin{array}{l}\text { Demonstrate Substantial } \\
\text { Damage }\end{array}$ & $\mathrm{N}$ \\
\hline & Other Criteria & $\begin{array}{l}\text { Both CDBG-MIT funds and FEMA HMGP funds } \\
\text { require grantees to conduct a multi-hazard risk } \\
\text { assessment to inform projects and programs. } \\
\text { grantee use of CDBG-MIT funds will be focused } \\
\text { on effectively addressing risks to indispensable } \\
\text { services that enable the continuous operation of } \\
\text { critical business and government functions, and that } \\
\text { are critical to the protection of human health and } \\
\text { safety, or economic security. }\end{array}$ \\
\hline & Additional Comments & \\
\hline
\end{tabular}




\section{National Oceanic and Atmospheric Administration (NOAA)}

\section{National Coastal Resilience Fund}

Link to Program: https://www.nfwf.org/programs/national-coastal-resilience-fund

Description of Program: Restores, increases and strengthens natural infrastructure to protect coastal communities while also enhancing habitats for fish and wildlife

\begin{tabular}{|c|c|c|}
\hline & Name of Program & National Coastal Resilience Fund \\
\hline \multirow[t]{2}{*}{ Resilience Focus } & $\begin{array}{l}\text { Resilience is a Program } \\
\text { Priority }\end{array}$ & Yes - community and ecosystem resilience \\
\hline & $\begin{array}{l}\text { Mitigation, Planning, } \\
\text { Response, Recovery }\end{array}$ & Mitigation \\
\hline \multirow[t]{3}{*}{ Program Funding } & Total Funds Available & FY2018 and 2019 Award up to $\$ 30$ million \\
\hline & $\begin{array}{l}\text { Funding Limitations Per } \\
\text { Application }\end{array}$ & $\begin{array}{l}\text { Expected range for planning awards: } \$ 100,000- \\
\$ 250,000 ; \$ 500,000-\$ 3,000,000 \text { for implementation } \\
\text { awards }\end{array}$ \\
\hline & Cost Share Requirements & $\begin{array}{l}1: 1 \text { non-federal match in cash or in-kind services } \\
\text { expected for all awards }\end{array}$ \\
\hline \multirow[t]{2}{*}{ Funding Timing } & Application Deadlines & $\begin{array}{l}\text { Specified in } 2018 \text { program overview; August 7, } \\
2018\end{array}$ \\
\hline & Length of Benefit & $\begin{array}{l}18 \text { months for planning awards; } 3 \text { years for } \\
\text { implementation awards }\end{array}$ \\
\hline \multirow{4}{*}{$\begin{array}{l}\text { Targeted } \\
\text { Applicants and } \\
\text { Recipients }\end{array}$} & Eligible Applicants & State; Tribe; Territory; Local; PNP \\
\hline & Eligible Subapplicants & $\mathrm{N} / \mathrm{A}$ \\
\hline & Eligible Recipients & $\begin{array}{l}\text { Coastal Communities (defined by Hydrologic Unit } \\
\text { Code } 8 \text { Watersheds) }\end{array}$ \\
\hline & $\begin{array}{l}\text { Low-Income, Impoverished } \\
\text { Community Status } \\
\text { Prioritized }\end{array}$ & $\mathrm{N}$ \\
\hline \multirow{3}{*}{$\begin{array}{l}\text { Hazard } \\
\text { Categorization }\end{array}$} & Hazards Included & Coastal Hazard \\
\hline & $\begin{array}{l}\text { Funding for Pre-disaster } \\
\text { Activities }\end{array}$ & $\mathrm{Y}$, not tied to specific disaster \\
\hline & $\begin{array}{l}\text { Funding for Post-disaster } \\
\text { Activities }\end{array}$ & $\mathrm{Y}$, not tied to specific disaster \\
\hline \multirow[t]{2}{*}{$\begin{array}{l}\text { Disaster } \\
\text { Declaration }\end{array}$} & $\begin{array}{l}\text { Disaster Declaration } \\
\text { Required }\end{array}$ & $\mathrm{N}$ \\
\hline & $\begin{array}{l}\text { Unusual Circumstances } \\
\text { Accepted }\end{array}$ & $\mathrm{N}$ \\
\hline \multirow[t]{3}{*}{ Projects Funded } & $\begin{array}{l}\text { Type of Facility or Land } \\
\text { Funded }\end{array}$ & Public land; Private land \\
\hline & Other Assistance Provided & $\mathrm{N} / \mathrm{A}$ \\
\hline & Project Types & $\begin{array}{l}\text { reduce regional threats to coastal communities } \\
\text { including storm surge, increased flooding, } \\
\text { subsidence, erosion, loss of sea ice, sea level rise }\end{array}$ \\
\hline \multirow{4}{*}{$\begin{array}{l}\text { Financial } \\
\text { Application } \\
\text { Requirements }\end{array}$} & $\begin{array}{l}\text { Demonstrate Work is Cost } \\
\text { Effective }\end{array}$ & $\begin{array}{l}\text { Y; budget must be cost-effective, in-line with } \\
\text { industry standards }\end{array}$ \\
\hline & $\begin{array}{l}\text { Demonstrate No Available } \\
\text { Help Found Elsewhere }\end{array}$ & \\
\hline & $\begin{array}{l}\text { Demonstrate Financial } \\
\text { History }\end{array}$ & \\
\hline & $\begin{array}{l}\text { Existing Plan / Strategy } \\
\text { Required }\end{array}$ & $\begin{array}{l}\text { Implementation projects must be prioritized in } \\
\text { existing plans (e.g., State Wildlife Action Plan) }\end{array}$ \\
\hline
\end{tabular}




\begin{tabular}{|c|c|c|}
\hline \multirow[t]{9}{*}{$\begin{array}{l}\text { Other Application } \\
\text { Requirements \& } \\
\text { Criteria }\end{array}$} & $\begin{array}{l}\text { Special Requirements or } \\
\text { Benefits for Special Flood } \\
\text { Hazard Areas }\end{array}$ & $\mathrm{N}$ \\
\hline & $\begin{array}{l}\text { Participate / Good Standing } \\
\text { with National Flood } \\
\text { Insurance Program }\end{array}$ & $\mathrm{N} / \mathrm{A}$ \\
\hline & Existing Insurance Required & $\mathrm{N} / \mathrm{A}$ \\
\hline & $\begin{array}{l}\text { Demonstrate NEPA } \\
\text { Compliance }\end{array}$ & $\begin{array}{l}\text { Y; proposals demonstrate plan will meet } \\
\text { requirements for environmental review, EHP } \\
\text { compliance }\end{array}$ \\
\hline & Public Outreach Prioritized & $\mathrm{Y}$ \\
\hline & $\begin{array}{l}\text { Building Code Adoption } \\
\text { Required }\end{array}$ & $\mathrm{N}$ \\
\hline & $\begin{array}{l}\text { Demonstrate Substantial } \\
\text { Damage }\end{array}$ & $\mathrm{N}$ \\
\hline & Other Criteria & $\begin{array}{l}\text { Explain how key stakeholders (government and } \\
\text { resource agencies) will be involved in project } \\
\text { planning } \\
\text { All projects evaluated on technical merit; } \\
\text { transferability of lessons learned to other } \\
\text { communities; communication to appropriate } \\
\text { audiences; plan for monitoring project progress; } \\
\text { long-term sustainability; past-success, partnership } \\
\text { with other government or cooperatives; higher } \\
\text { priority given to projects with permits already } \\
\text { secured }\end{array}$ \\
\hline & Additional Comments & \\
\hline
\end{tabular}




\section{Coastal Zone Management Program}

Link to Program: https://coast.noaa.gov/czm/

Description of Program: Provides the basis for protecting, restoring, and responsibly developing our nation's diverse coastal communities and resources as a voluntary partnership between the federal government and U.S. coastal and Great Lakes states and territories authorized by the Coastal Zone Management Act (CZMA) of 1972 to address national coastal issues

\begin{tabular}{|c|c|c|}
\hline & Name of Program & Coastal Zone Management Program \\
\hline \multirow[t]{2}{*}{ Resilience Focus } & $\begin{array}{l}\text { Resilience is a Program } \\
\text { Priority }\end{array}$ & $\begin{array}{l}\text { Yes - Community and ecosystem resilience; } \\
\text { funding mostly for planning and program } \\
\text { administration; limited funding for small-scale } \\
\text { construction. }\end{array}$ \\
\hline & $\begin{array}{l}\text { Mitigation, Planning, } \\
\text { Response, Recovery }\end{array}$ & Mitigation \\
\hline \multirow[t]{3}{*}{ Program Funding } & Total Funds Available & $\begin{array}{l}\text { FY2018 and } 2019 \text { Award approx. } \$ 70 \text { million; not all } \\
\text { dedicated to resilience projects. Focus of funding at } \\
\text { discretion of state coastal zone management } \\
\text { programs }\end{array}$ \\
\hline & $\begin{array}{l}\text { Funding Limitations Per } \\
\text { Application }\end{array}$ & Approx. 2.5M \\
\hline & Cost Share Requirements & Approx 1:1 with exceptions for Pacific territories. \\
\hline \multirow[t]{2}{*}{ Funding Timing } & Application Deadlines & $\begin{array}{l}\text { N/A - states must have a federally approved } \\
\text { Coastal Management Program to receive funds but } \\
\text { do not need to reapply competitively each year; } \\
\text { exception is if applying for Section } 309 \text { Coastal } \\
\text { Zone Enhancement Program Project of Special } \\
\text { Merit funds }\end{array}$ \\
\hline & Length of Benefit & $\begin{array}{l}\text { Awards provided annually to participating states } \\
\text { and territories (currently } 34 \text { ) based on a } \\
\text { Congressionally set formula }\end{array}$ \\
\hline \multirow{4}{*}{$\begin{array}{l}\text { Targeted } \\
\text { Applicants and } \\
\text { Recipients }\end{array}$} & Eligible Applicants & State; Territory \\
\hline & Eligible Subapplicants & $\mathrm{N}$ \\
\hline & Eligible Recipients & State; Territory \\
\hline & $\begin{array}{l}\text { Low-Income, Impoverished } \\
\text { Community Status } \\
\text { Prioritized }\end{array}$ & $\mathrm{N}$ \\
\hline \multirow{3}{*}{$\begin{array}{l}\text { Hazard } \\
\text { Categorization }\end{array}$} & Hazards Included & Coastal Hazard \\
\hline & $\begin{array}{l}\text { Funding for Pre-disaster } \\
\text { Activities }\end{array}$ & $\mathrm{Y}$, not tied to specific disaster \\
\hline & $\begin{array}{l}\text { Funding for Post-disaster } \\
\text { Activities }\end{array}$ & $\mathrm{Y}$, not tied to specific disaster \\
\hline \multirow[t]{2}{*}{$\begin{array}{l}\text { Disaster } \\
\text { Declaration }\end{array}$} & $\begin{array}{l}\text { Disaster Declaration } \\
\text { Required }\end{array}$ & $\mathrm{N}$ \\
\hline & $\begin{array}{l}\text { Unusual Circumstances } \\
\text { Accepted }\end{array}$ & $\mathrm{N}$ \\
\hline \multirow[t]{3}{*}{ Projects Funded } & $\begin{array}{l}\text { Type of Facility or Land } \\
\text { Funded }\end{array}$ & For construction or acquisition, public land \\
\hline & Other Assistance Provided & $\begin{array}{l}\text { NOAA provides technical assistance as well as } \\
\text { funding }\end{array}$ \\
\hline & Project Types & enhance coastal resilience to hazards \\
\hline \multirow{2}{*}{$\begin{array}{l}\text { Financial } \\
\text { Application } \\
\text { Requirements }\end{array}$} & $\begin{array}{l}\text { Demonstrate Work is Cost } \\
\text { Effective }\end{array}$ & $\mathrm{N}$, based on formula set by Congress \\
\hline & $\begin{array}{l}\text { Demonstrate No Available } \\
\text { Help Found Elsewhere }\end{array}$ & \\
\hline
\end{tabular}




\begin{tabular}{|l|l|l|}
\hline & $\begin{array}{l}\text { Demonstrate Financial } \\
\text { History }\end{array}$ & $\begin{array}{l}\text { Y, standard NOAA and Dept of Commerce } \\
\text { financial assistance regulations apply }\end{array}$ \\
\hline $\begin{array}{l}\text { Other Application } \\
\text { Requirements \& }\end{array}$ & $\begin{array}{l}\text { Existing Plan / Strategy } \\
\text { Required }\end{array}$ & $\begin{array}{l}\text { Y - states must have a federally approved Coastal } \\
\text { Management Program to receive funds }\end{array}$ \\
\cline { 2 - 3 } & $\begin{array}{l}\text { Special Requirements or } \\
\text { Benefits for Special Flood } \\
\text { Hazard Areas }\end{array}$ & $\mathrm{N}$ \\
\cline { 2 - 3 } & $\begin{array}{l}\text { Participate / Good Standing } \\
\text { with National Flood } \\
\text { Insurance Program }\end{array}$ & $\begin{array}{l}\text { Y for low cost construction projects under CZMA } \\
\text { Section 306A }\end{array}$ \\
\cline { 2 - 3 } & Existing Insurance Required & $\begin{array}{l}\text { Y for low cost construction projects under CZMA } \\
\text { Section 306A }\end{array}$ \\
\cline { 2 - 3 } & $\begin{array}{l}\text { Demonstrate NEPA } \\
\text { Compliance }\end{array}$ & $\begin{array}{l}\text { Y for low cost construction projects under CZMA } \\
\text { Section 306A }\end{array}$ \\
\cline { 2 - 3 } & Public Outreach Prioritized & Y \\
\cline { 2 - 3 } & $\begin{array}{l}\text { Building Code Adoption } \\
\text { Required }\end{array}$ & N \\
\cline { 2 - 3 } & $\begin{array}{l}\text { Demonstrate Substantial } \\
\text { Damage }\end{array}$ & N \\
\cline { 2 - 3 } & Other Criteria & $\begin{array}{l}\text { Environmental compliance under NEPA and other } \\
\text { statutes is assured. Also, recipients must have } \\
\text { federally approved coastal management program }\end{array}$ \\
\hline & Additional Comments & \\
\hline & & \\
\hline
\end{tabular}




\section{Small Business Administration (SBA)}

\section{Economic Injury Disaster Loans - Business}

Link to Program: https://disasterloan.sba.gov/ela/Information/EIDLLoans

Description of Program: Substantial economic injury means the business is unable to meet its obligations and to pay its ordinary and necessary operating expenses. EIDLs provide the necessary working capital to help small businesses survive until normal operations resume after a disaster.

\begin{tabular}{|c|c|c|}
\hline & Name of Program & Economic Injury Disaster Loans - Business \\
\hline \multirow[t]{2}{*}{ Resilience Focus } & $\begin{array}{l}\text { Resilience is a Program } \\
\text { Priority }\end{array}$ & \\
\hline & $\begin{array}{l}\text { Mitigation, Planning, } \\
\text { Response, Recovery }\end{array}$ & Response, Recovery \\
\hline \multirow[t]{3}{*}{ Program Funding } & Total Funds Available & \\
\hline & $\begin{array}{l}\text { Funding Limitations Per } \\
\text { Application }\end{array}$ & $\begin{array}{l}\$ 2,000,000 \text { by statute, unless SBA waives limit } \\
\text { because business is a major source of employment; } \\
\text { collateral required for loans }>\$ 25,000 \text {, if available }\end{array}$ \\
\hline & Cost Share Requirements & No matching requirements \\
\hline \multirow[t]{2}{*}{ Funding Timing } & Application Deadlines & \\
\hline & Length of Benefit & $\begin{array}{l}15 \text { or } 30 \text { years; } 7 \text { if Business has credit available } \\
\text { elsewhere }\end{array}$ \\
\hline \multirow{4}{*}{$\begin{array}{l}\text { Targeted } \\
\text { Applicants and } \\
\text { Recipients }\end{array}$} & Eligible Applicants & $\begin{array}{l}\text { Small Business; Small Agricultural Cooperative; } \\
\text { most PNP }\end{array}$ \\
\hline & Eligible Subapplicants & $\mathrm{N}$ \\
\hline & Eligible Recipients & $\begin{array}{l}\text { Small Business; Small Agricultural Cooperative; } \\
\text { most PNP }\end{array}$ \\
\hline & $\begin{array}{l}\text { Low-Income, Impoverished } \\
\text { Community Status } \\
\text { Prioritized }\end{array}$ & \\
\hline \multirow{3}{*}{$\begin{array}{l}\text { Hazard } \\
\text { Categorization }\end{array}$} & Hazards Included & All \\
\hline & $\begin{array}{l}\text { Funding for Pre-disaster } \\
\text { Activities }\end{array}$ & $\mathrm{N}$ \\
\hline & $\begin{array}{l}\text { Funding for Post-disaster } \\
\text { Activities }\end{array}$ & $\mathrm{Y}$ \\
\hline \multirow[t]{2}{*}{$\begin{array}{l}\text { Disaster } \\
\text { Declaration }\end{array}$} & $\begin{array}{l}\text { Disaster Declaration } \\
\text { Required }\end{array}$ & $\begin{array}{l}\text { Y; SBA; Major Presidential; Governor's } \\
\text { Certification; Secretary of Agriculture; Secretary of } \\
\text { Commerce }\end{array}$ \\
\hline & $\begin{array}{l}\text { Unusual Circumstances } \\
\text { Accepted }\end{array}$ & $\mathrm{N}$ \\
\hline \multirow[t]{3}{*}{ Projects Funded } & $\begin{array}{l}\text { Type of Facility or Land } \\
\text { Funded }\end{array}$ & None \\
\hline & Other Assistance Provided & Y; working capital loans \\
\hline & Project Types & $\begin{array}{l}\text { help sustain operations and meet financial } \\
\text { obligation that cannot be met due to disaster }\end{array}$ \\
\hline \multirow{3}{*}{$\begin{array}{l}\text { Financial } \\
\text { Application } \\
\text { Requirements }\end{array}$} & $\begin{array}{l}\text { Demonstrate Work is Cost } \\
\text { Effective }\end{array}$ & \\
\hline & $\begin{array}{l}\text { Demonstrate No Available } \\
\text { Help Found Elsewhere }\end{array}$ & $\begin{array}{l}\text { Currently, } 4 \% \text { interest rate max for business } \\
\text { applicants without credit elsewhere; } 8 \% \text { interest } \\
\text { rate max otherwise; } 2.75 \% \text { for PNP }\end{array}$ \\
\hline & $\begin{array}{l}\text { Demonstrate Financial } \\
\text { History }\end{array}$ & Y; Credit history acceptable to SBA \\
\hline
\end{tabular}




\begin{tabular}{|l|l|l|}
\hline $\begin{array}{l}\text { Other Application } \\
\text { Requirements \& } \\
\text { Criteria }\end{array}$ & $\begin{array}{l}\text { Existing Plan / Strategy } \\
\text { Required }\end{array}$ & \\
\cline { 2 - 3 } & $\begin{array}{l}\text { Special Requirements or } \\
\text { Benefits for Special Flood } \\
\text { Hazard Areas }\end{array}$ & \\
\cline { 2 - 3 } & $\begin{array}{l}\text { Participate / Good Standing } \\
\text { with National Flood } \\
\text { Insurance Program }\end{array}$ & \\
\hline & Existing Insurance Required & Funding for costs not covered by insurance \\
\hline & $\begin{array}{l}\text { Demonstrate NEPA } \\
\text { Compliance }\end{array}$ & \\
\hline & Public Outreach Prioritized & \\
\hline & $\begin{array}{l}\text { Building Code Adoption } \\
\text { Required }\end{array}$ & \\
\cline { 2 - 3 } & $\begin{array}{l}\text { Demonstrate Substantial } \\
\text { Damage }\end{array}$ & \\
\hline & Other Criteria & \\
\hline & Additional Comments & \\
\hline & & \\
\hline
\end{tabular}




\section{Home and Personal Property Loans}

Link to Program: https://disasterloan.sba.gov/ela/Information/HomePersonalPropertyLoans

Description of Program: If you are in a declared disaster area and are the victim of a disaster, you may be eligible for a low-interest rate disaster loan from the U.S. Small Business Administration - even if you don't own a business. As a homeowner, renter and/or personal-property owner, you may apply to the SBA for a loan to help you recover from a disaster.

\begin{tabular}{|c|c|c|}
\hline & Name of Program & Home and Personal Property Loans \\
\hline \multirow[t]{2}{*}{ Resilience Focus } & $\begin{array}{l}\text { Resilience is a Program } \\
\text { Priority }\end{array}$ & \\
\hline & $\begin{array}{l}\text { Mitigation, Planning, } \\
\text { Response, Recovery }\end{array}$ & Response, Recovery \\
\hline \multirow[t]{3}{*}{ Program Funding } & Total Funds Available & \\
\hline & $\begin{array}{l}\text { Funding Limitations Per } \\
\text { Application }\end{array}$ & $\begin{array}{l}\$ 200,000 \text { for primary resident; } \$ 40,000 \text { for personal } \\
\text { property; collateral required for loans }>\$ 25,000 \text {, if } \\
\text { available }\end{array}$ \\
\hline & Cost Share Requirements & \\
\hline \multirow[t]{2}{*}{ Funding Timing } & Application Deadlines & \\
\hline & Length of Benefit & 15 or 30 years \\
\hline \multirow{4}{*}{$\begin{array}{l}\text { Targeted } \\
\text { Applicants and } \\
\text { Recipients }\end{array}$} & Eligible Applicants & Homeowner; Renter \\
\hline & Eligible Subapplicants & $\mathrm{N}$ \\
\hline & Eligible Recipients & Homeowner; Renter \\
\hline & $\begin{array}{l}\text { Low-Income, Impoverished } \\
\text { Community Status } \\
\text { Prioritized }\end{array}$ & \\
\hline \multirow{3}{*}{$\begin{array}{l}\text { Hazard } \\
\text { Categorization }\end{array}$} & Hazards Included & All \\
\hline & $\begin{array}{l}\text { Funding for Pre-disaster } \\
\text { Activities }\end{array}$ & $\mathrm{N}$ \\
\hline & $\begin{array}{l}\text { Funding for Post-disaster } \\
\text { Activities }\end{array}$ & $\mathrm{Y}$ \\
\hline \multirow[t]{2}{*}{$\begin{array}{l}\text { Disaster } \\
\text { Declaration }\end{array}$} & $\begin{array}{l}\text { Disaster Declaration } \\
\text { Required }\end{array}$ & Y; SBA or Major Presidential \\
\hline & $\begin{array}{l}\text { Unusual Circumstances } \\
\text { Accepted }\end{array}$ & $\mathrm{N}$ \\
\hline \multirow[t]{3}{*}{ Projects Funded } & $\begin{array}{l}\text { Type of Facility or Land } \\
\text { Funded }\end{array}$ & Private-primary residence \\
\hline & Other Assistance Provided & $\begin{array}{l}\text { Y; Personal property loans; mitigation; refinance; } \\
\text { contractor malfeasance. }\end{array}$ \\
\hline & Project Types & $\begin{array}{l}\text { Repair or replace homes or personal property that } \\
\text { sustained damages not covered by insurance. }\end{array}$ \\
\hline \multirow{3}{*}{$\begin{array}{l}\text { Financial } \\
\text { Application } \\
\text { Requirements }\end{array}$} & $\begin{array}{l}\text { Demonstrate Work is Cost } \\
\text { Effective }\end{array}$ & \\
\hline & $\begin{array}{l}\text { Demonstrate No Available } \\
\text { Help Found Elsewhere }\end{array}$ & $\begin{array}{l}\text { Currently, } 1.938 \% \text { interest rate max for applicants } \\
\text { without credit elsewhere; } 3.875 \% \text { interest rate max } \\
\text { otherwise. }\end{array}$ \\
\hline & $\begin{array}{l}\text { Demonstrate Financial } \\
\text { History }\end{array}$ & Y; Credit history acceptable to SBA. \\
\hline \multirow{2}{*}{$\begin{array}{l}\text { Other Application } \\
\text { Requirements \& } \\
\text { Criteria }\end{array}$} & $\begin{array}{l}\text { Existing Plan / Strategy } \\
\text { Required }\end{array}$ & \\
\hline & $\begin{array}{l}\text { Special Requirements or } \\
\text { Benefits for Special Flood } \\
\text { Hazard Areas }\end{array}$ & Y; SFHA borrowers must purchase insurance. \\
\hline
\end{tabular}




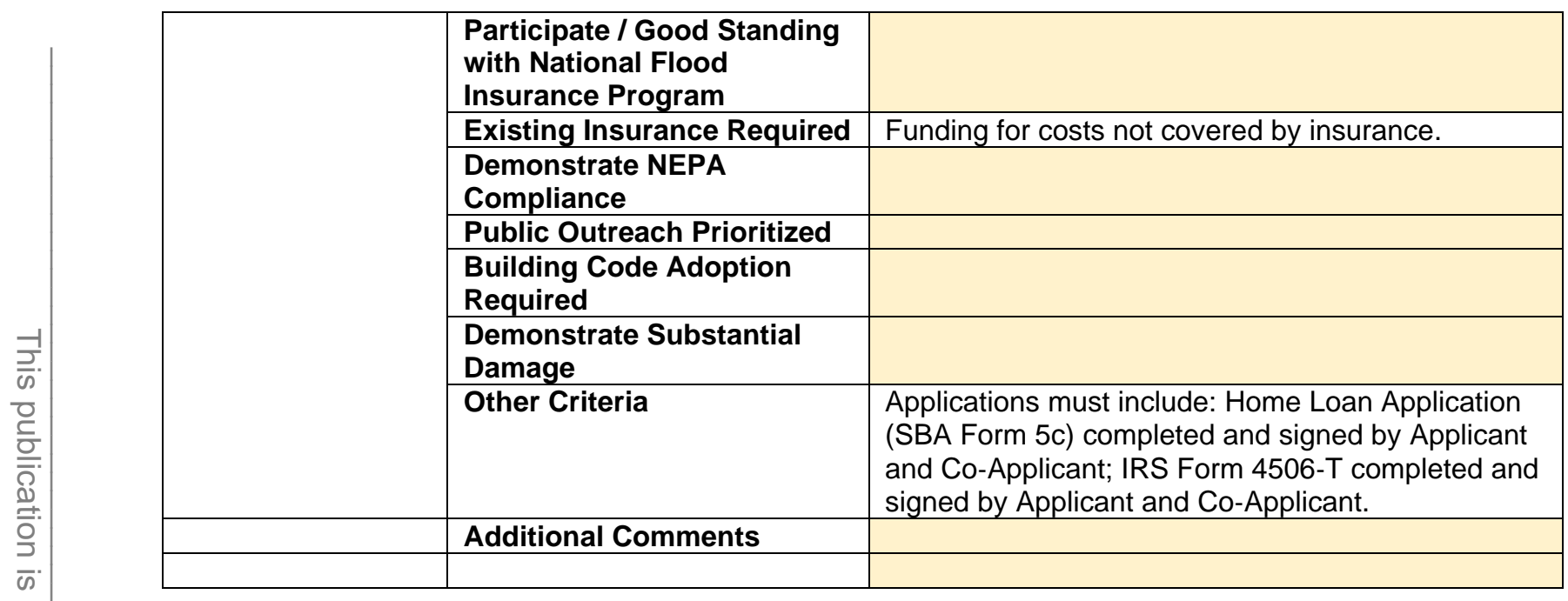




\section{Physical Disaster Loans - Business}

Link to Program: https://disasterloan.sba.gov/ela/Information/BusinessPhysicalLoans

Description of Program: If you are in a declared disaster area and have experienced damage to your business, you may be eligible for financial assistance from the SBA. Businesses of any size and most private nonprofit organizations may apply to the SBA for a loan to recover after a disaster.

\begin{tabular}{|c|c|c|}
\hline & Name of Program & Physical Disaster Loans - Business \\
\hline \multirow[t]{2}{*}{ Resilience Focus } & $\begin{array}{l}\text { Resilience is a Program } \\
\text { Priority }\end{array}$ & \\
\hline & $\begin{array}{l}\text { Mitigation, Planning, } \\
\text { Response, Recovery }\end{array}$ & Response, Recovery \\
\hline \multirow[t]{3}{*}{ Program Funding } & Total Funds Available & \\
\hline & $\begin{array}{l}\text { Funding Limitations Per } \\
\text { Application }\end{array}$ & $\begin{array}{l}\$ 2,000,000 \text { by statute, unless SBA waives limit } \\
\text { because business is a major source of employment; } \\
\text { collateral required for loans }>\$ 25,000 \text {, if available. }\end{array}$ \\
\hline & Cost Share Requirements & No matching requirements. \\
\hline \multirow[t]{2}{*}{ Funding Timing } & Application Deadlines & \\
\hline & Length of Benefit & $\begin{array}{l}15 \text { or } 30 \text { years; } 7 \text { yrs if Business has credit } \\
\text { available elsewhere. }\end{array}$ \\
\hline \multirow{4}{*}{$\begin{array}{l}\text { Targeted } \\
\text { Applicants and } \\
\text { Recipients }\end{array}$} & Eligible Applicants & Business (of any size); PNP \\
\hline & Eligible Subapplicants & $\mathrm{N}$ \\
\hline & Eligible Recipients & Business (of any size); PNP \\
\hline & $\begin{array}{l}\text { Low-Income, Impoverished } \\
\text { Community Status } \\
\text { Prioritized }\end{array}$ & \\
\hline \multirow{3}{*}{$\begin{array}{l}\text { Hazard } \\
\text { Categorization }\end{array}$} & Hazards Included & All \\
\hline & $\begin{array}{l}\text { Funding for Pre-disaster } \\
\text { Activities }\end{array}$ & $\mathrm{N}$ \\
\hline & $\begin{array}{l}\text { Funding for Post-disaster } \\
\text { Activities }\end{array}$ & $\mathrm{Y}$ \\
\hline \multirow[t]{2}{*}{$\begin{array}{l}\text { Disaster } \\
\text { Declaration }\end{array}$} & $\begin{array}{l}\text { Disaster Declaration } \\
\text { Required }\end{array}$ & Y; SBA or Major Presidential \\
\hline & $\begin{array}{l}\text { Unusual Circumstances } \\
\text { Accepted }\end{array}$ & $\mathrm{N}$ \\
\hline \multirow[t]{3}{*}{ Projects Funded } & $\begin{array}{l}\text { Type of Facility or Land } \\
\text { Funded }\end{array}$ & Private \\
\hline & Other Assistance Provided & $\begin{array}{l}\text { Y; personal property loans; mitigation; refinance; } \\
\text { contractor malfeasance. }\end{array}$ \\
\hline & Project Types & $\begin{array}{l}\text { Repair or replace business that sustained damages } \\
\text { not covered by insurance, including real estate, } \\
\text { machinery and equipment, leasehold } \\
\text { improvements, furniture and fixtures, and inventory. }\end{array}$ \\
\hline \multirow{4}{*}{$\begin{array}{l}\text { Financial } \\
\text { Application } \\
\text { Requirements }\end{array}$} & $\begin{array}{l}\text { Demonstrate Work is Cost } \\
\text { Effective }\end{array}$ & \\
\hline & $\begin{array}{l}\text { Demonstrate No Available } \\
\text { Help Found Elsewhere }\end{array}$ & $\begin{array}{l}\text { Currently, } 4 \% \text { interest rate max for business } \\
\text { applicants without credit elsewhere; } 8 \% \text { interest } \\
\text { rate max otherwise; } 2.75 \% \text { for PNP. }\end{array}$ \\
\hline & $\begin{array}{l}\text { Demonstrate Financial } \\
\text { History }\end{array}$ & Y; Credit history acceptable to SBA. \\
\hline & $\begin{array}{l}\text { Existing Plan / Strategy } \\
\text { Required }\end{array}$ & \\
\hline
\end{tabular}




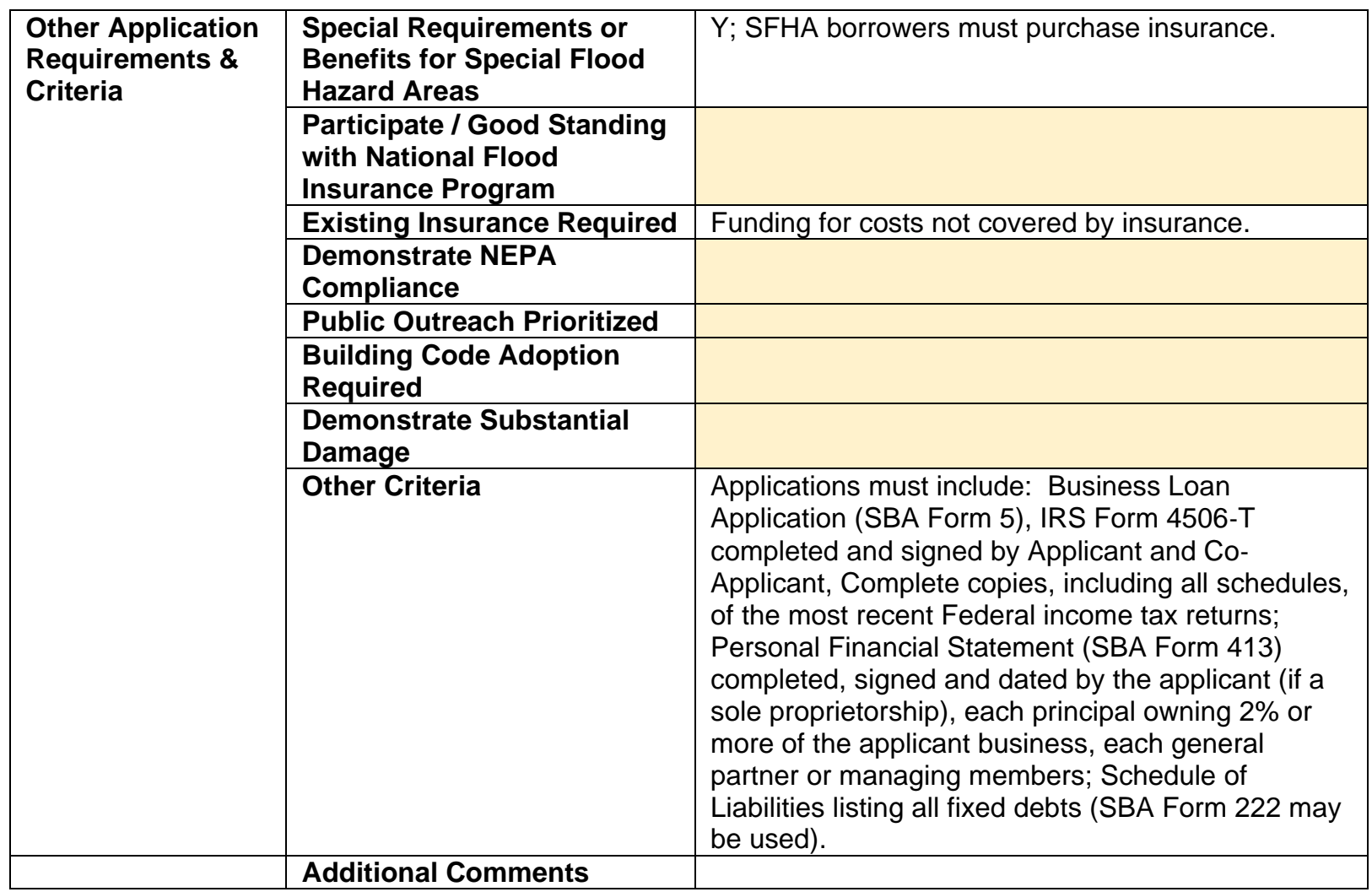




\section{U.S. Army Corps of Engineers (USACE)}

\section{Continuing Authorities Program}

Link to Program: https://www.nae.usace.army.mil/Missions/Public-Services/ContinuingAuthorities-Program/;

https://planning.erdc.dren.mil/toolbox/processes.cfm?Id=229\&Option=Continuing\%20Authoriti es\%20Program\%20(CAP)

Description of Program: Group of nine legislative authorities under which the Corps of Engineers can plan, design, and implement certain types of water resources projects without additional project specific congressional authorization

\begin{tabular}{|c|c|c|}
\hline & Name of Program & Continuing Authorities \\
\hline \multirow[t]{2}{*}{ Resilience Focus } & $\begin{array}{l}\text { Resilience is a Program } \\
\text { Priority }\end{array}$ & $\begin{array}{l}\text { Y; As defined by states and communities receiving } \\
\text { assistance. }\end{array}$ \\
\hline & $\begin{array}{l}\text { Mitigation, Planning, } \\
\text { Response, Recovery }\end{array}$ & Mitigation \\
\hline \multirow[t]{3}{*}{ Program Funding } & Total Funds Available & $\begin{array}{l}\text { In FY19 there was } \$ 66 \mathrm{M} \text { in new appropriations } \\
\text { across the } 8 \text { CAP authorities, with carry-in there } \\
\text { was a total of } \$ 121 \mathrm{M} \text { available. Approx. } \$ 45 \mathrm{M} \text { was } \\
\text { available for the FRM authorities (Sec } 14,103 \text { and } \\
\text { 205). }\end{array}$ \\
\hline & $\begin{array}{l}\text { Funding Limitations Per } \\
\text { Application }\end{array}$ & $\begin{array}{l}\text { All CAP projects have a Federal Per project } \\
\text { participation limit. Sec } 14 \text { is } \$ 5 \mathrm{M} \text { and Sec } 205 \text { and } \\
103 \text { are } \$ 10 \mathrm{M} \text {. }\end{array}$ \\
\hline & Cost Share Requirements & $\begin{array}{l}\text { For planning, Fed cost-share is } 50 \% \text { beyond } \\
\$ 100,000 \text {. For implementation the FRM cost-share } \\
\text { is generally } 65 \% \text { Fed } 35 \% \text { non-Fed, with non-Fed } \\
\text { responsible for lands, easements, rights of way, } \\
\text { disposal areas, and operation and maintenance. }\end{array}$ \\
\hline \multirow[t]{2}{*}{ Funding Timing } & Application Deadlines & $\begin{array}{l}\text { Projects are started through an affordability analysis } \\
\text { and a new start selection review. }\end{array}$ \\
\hline & Length of Benefit & Varies, dependent on design life of project \\
\hline \multirow[t]{4}{*}{$\begin{array}{l}\text { Targeted } \\
\text { Applicants and } \\
\text { Recipients }\end{array}$} & Eligible Applicants & $\begin{array}{l}\text { State; Local governments; watershed districts; } \\
\text { tribes; territories; and in some cases NGOs with } \\
\text { governmental partner }\end{array}$ \\
\hline & Eligible Subapplicants & $\mathrm{N} / \mathrm{A}$ \\
\hline & Eligible Recipients & $\begin{array}{l}\text { Constituent citizens and businesses of applicant } \\
\text { jurisdiction }\end{array}$ \\
\hline & $\begin{array}{l}\text { Low-Income, Impoverished } \\
\text { Community Status } \\
\text { Prioritized }\end{array}$ & Dependent on area targeted by applicant \\
\hline \multirow[t]{3}{*}{$\begin{array}{l}\text { Hazard } \\
\text { Categorization }\end{array}$} & Hazards Included & $\begin{array}{l}\text { Flood; Coastal; public infrastructure at risk due to } \\
\text { Stream bank }\end{array}$ \\
\hline & $\begin{array}{l}\text { Funding for Pre-disaster } \\
\text { Activities }\end{array}$ & Inland \& coastal flood areas \\
\hline & $\begin{array}{l}\text { Funding for Post-disaster } \\
\text { Activities }\end{array}$ & Inland \& coastal flood areas \\
\hline \multirow[t]{2}{*}{$\begin{array}{l}\text { Disaster } \\
\text { Declaration }\end{array}$} & $\begin{array}{l}\text { Disaster Declaration } \\
\text { Required }\end{array}$ & $\mathrm{N}$ \\
\hline & $\begin{array}{l}\text { Unusual Circumstances } \\
\text { Accepted }\end{array}$ & Y; Must meet the authority requirements. \\
\hline Projects Funded & $\begin{array}{l}\text { Type of Facility or Land } \\
\text { Funded }\end{array}$ & Public \\
\hline
\end{tabular}




\begin{tabular}{|c|c|c|}
\hline & Other Assistance Provided & None \\
\hline & Project Types & $\begin{array}{l}\text { Variety of projects of limited size, cost, scope and } \\
\text { complexity according to } 9 \text { authorities (Sec 14, 103, } \\
\text { and } 205 \text { are used for FRM). }\end{array}$ \\
\hline $\begin{array}{l}\text { Financial } \\
\text { Application }\end{array}$ & $\begin{array}{l}\text { Demonstrate Work is Cost } \\
\text { Effective }\end{array}$ & Y; Economic justification is required. \\
\hline Requirements & $\begin{array}{l}\text { Demonstrate No Available } \\
\text { Help Found Elsewhere }\end{array}$ & $\mathrm{N}$ \\
\hline & $\begin{array}{l}\text { Demonstrate Financial } \\
\text { History }\end{array}$ & $\mathrm{N}$ \\
\hline $\begin{array}{l}\text { Other Application } \\
\text { Requirements \& }\end{array}$ & $\begin{array}{l}\text { Existing Plan / Strategy } \\
\text { Required }\end{array}$ & $\mathrm{N}$ \\
\hline Criteria & $\begin{array}{l}\text { Special Requirements or } \\
\text { Benefits for Special Flood } \\
\text { Hazard Areas }\end{array}$ & $\mathrm{N}$ \\
\hline & $\begin{array}{l}\text { Participate / Good Standing } \\
\text { with National Flood } \\
\text { Insurance Program }\end{array}$ & $\mathrm{N} / \mathrm{A}$ \\
\hline & Existing Insurance Required & $\mathrm{N} / \mathrm{A}$ \\
\hline & $\begin{array}{l}\text { Demonstrate NEPA } \\
\text { Compliance }\end{array}$ & $\mathrm{Y}$ \\
\hline & Public Outreach Prioritized & $\mathrm{N} / \mathrm{A}$ \\
\hline & $\begin{array}{l}\text { Building Code Adoption } \\
\text { Required }\end{array}$ & $\mathrm{N} / \mathrm{A}$ \\
\hline & $\begin{array}{l}\text { Demonstrate Substantial } \\
\text { Damage }\end{array}$ & $\mathrm{N}$ \\
\hline & Other Criteria & \\
\hline & & $\mathrm{N} / \mathrm{A}$ \\
\hline & Additional Comments & $\mathrm{N} / \mathrm{A}$ \\
\hline
\end{tabular}




\section{Emergency Operations: Flood Control and Coastal Emergencies}

Link to Program: https://www.usace.army.mil/Missions/Emergency-Operations/NationalResponse-Framework/Flood-Control/

Description of Program: Under PL 84-99, the Chief of Engineers, acting for the Secretary of the Army, is authorized to undertake activities including disaster preparedness, Advance Measures, emergency operations (Flood Response and Post Flood Response), rehabilitation of eligible flood risk management projects threatened or destroyed by flood, protection or repair of eligible federally authorized coastal storm risk management projects threatened or damaged by coastal storm, and provisions of emergency water due to drought or contaminated source. Assistance is provided as technical or direct by assigned USACE district and supplementary to State, Tribal, Territorial, or Local assistance. No grants or reimbursements are authorized.

\begin{tabular}{|c|c|c|}
\hline & Name of Program & $\begin{array}{l}\text { Emergency Operations: Flood Control and } \\
\text { Coastal Emergencies }\end{array}$ \\
\hline \multirow[t]{2}{*}{ Resilience Focus } & $\begin{array}{l}\text { Resilience is a Program } \\
\text { Priority }\end{array}$ & $\begin{array}{l}\text { Y; In response and recovery operations on } \\
\text { structures and services within USACE mission. }\end{array}$ \\
\hline & $\begin{array}{l}\text { Mitigation, Planning, } \\
\text { Response, Recovery }\end{array}$ & Response \\
\hline \multirow[t]{3}{*}{ Program Funding } & Total Funds Available & Approximately $\$ 35 \mathrm{M}$ per year. \\
\hline & $\begin{array}{l}\text { Funding Limitations Per } \\
\text { Application }\end{array}$ & $\begin{array}{l}\text { No official limit but each request is typically less } \\
\text { than } \$ 1 \mathrm{M} \text {. }\end{array}$ \\
\hline & Cost Share Requirements & Cost sharing requirements may apply. \\
\hline \multirow[t]{2}{*}{ Funding Timing } & Application Deadlines & $\begin{array}{l}\text { Assistance available upon request from USACE } \\
\text { Districts and subject to Engineering Regulation } 500 \\
1-1 .\end{array}$ \\
\hline & Length of Benefit & During applicable event period. \\
\hline \multirow{4}{*}{$\begin{array}{l}\text { Targeted } \\
\text { Applicants and } \\
\text { Recipients }\end{array}$} & Eligible Applicants & USACE districts \\
\hline & Eligible Subapplicants & $\mathrm{N} / \mathrm{A}$ \\
\hline & Eligible Recipients & $\begin{array}{l}\text { Citizens and businesses benefitting from USACE } \\
\text { technical or direct assistance. }\end{array}$ \\
\hline & $\begin{array}{l}\text { Low-Income, Impoverished } \\
\text { Community Status } \\
\text { Prioritized }\end{array}$ & $\mathrm{N}$ \\
\hline \multirow{3}{*}{$\begin{array}{l}\text { Hazard } \\
\text { Categorization }\end{array}$} & Hazards Included & Flood; Coastal \\
\hline & $\begin{array}{l}\text { Funding for Pre-disaster } \\
\text { Activities }\end{array}$ & Inland \& coastal flood areas \\
\hline & $\begin{array}{l}\text { Assistance for Post-disaster } \\
\text { Activities }\end{array}$ & Y; Subject to eligibility requirements. \\
\hline \multirow[t]{2}{*}{$\begin{array}{l}\text { Disaster } \\
\text { Declaration }\end{array}$} & $\begin{array}{l}\text { Disaster Declaration } \\
\text { Required }\end{array}$ & $\mathrm{N} / \mathrm{A}$ \\
\hline & $\begin{array}{l}\text { Unusual Circumstances } \\
\text { Accepted }\end{array}$ & $\mathrm{Y}$ \\
\hline \multirow[t]{3}{*}{ Projects Funded } & $\begin{array}{l}\text { Type of Facility or Land } \\
\text { Funded }\end{array}$ & Public \\
\hline & Other Assistance Provided & $\begin{array}{l}\text { Y; Emergency response, provision of critical } \\
\text { commodities. }\end{array}$ \\
\hline & Project Types & Critical public facilities and life safety. \\
\hline \multirow{2}{*}{$\begin{array}{l}\text { Financial } \\
\text { Application } \\
\text { Requirements }\end{array}$} & $\begin{array}{l}\text { Demonstrate Work is Cost } \\
\text { Effective }\end{array}$ & $\begin{array}{l}\text { Financial requirement for response and recovery } \\
\text { service determined by USACE }\end{array}$ \\
\hline & $\begin{array}{l}\text { Demonstrate No Available } \\
\text { Help Found Elsewhere }\end{array}$ & $\mathrm{N} / \mathrm{A}$ \\
\hline
\end{tabular}




\begin{tabular}{|l|l|l|}
\hline & $\begin{array}{l}\text { Demonstrate Financial } \\
\text { History }\end{array}$ & N \\
\hline $\begin{array}{l}\text { Other Application } \\
\text { Requirements \& } \\
\text { Criteria }\end{array}$ & $\begin{array}{l}\text { Existing Plan / Strategy } \\
\text { Required }\end{array}$ & N/A \\
\cline { 2 - 3 } & $\begin{array}{l}\text { Special Requirements or } \\
\text { Benefits for Special Flood } \\
\text { Hazard Areas }\end{array}$ & Y \\
\cline { 2 - 3 } & $\begin{array}{l}\text { Participate / Good Standing } \\
\text { with National Flood } \\
\text { Insurance Program }\end{array}$ & N/A \\
\cline { 2 - 3 } & Existing Insurance Required & N/A \\
\cline { 2 - 3 } Demonstrate NEPA & N/A \\
\cline { 2 - 3 } \\
\cline { 2 - 3 } & Pumpliance & N Outreach Prioritized \\
\cline { 2 - 3 } & $\begin{array}{l}\text { Building Code Adoption } \\
\text { Required }\end{array}$ & N/A \\
\cline { 2 - 3 } & $\begin{array}{l}\text { Demonstrate Substantial } \\
\text { Damage }\end{array}$ & N/A \\
\cline { 2 - 3 } & Other Criteria & N/A \\
\hline & Additional Comments & N/A \\
\hline
\end{tabular}




\section{Flood Plain Management Services Program}

Link to Program:

https://www.nae.usace.army.mil/missions/public-services/flood-plain-management-services

https://www.mvr.usace.army.mil/Business-With-Us/Outreach-Customer-Service/FloodplainManagement-Services/

Description of Program: Provides technical assistance and planning guidance to Federal agencies, states, local governments, other non-Federal entities, eligible Tribes and the private sector to support effective floodplain management. This may include obtaining, interpreting, or developing data about flood sources and types, flood depths and water surface elevations, floodwater velocity, flooding extent and duration, flood frequency, and obstruction of flood flows. It may also include larger scale "special studies" on all aspects of floodplain management, including floodplain mapping, dam break analyses, regulatory floodway studies, flood warning and emergency preparedness, and flood damage reduction studies. Allows for technical assistance only, cannot conduct site-specific design or fund construction.

\begin{tabular}{|c|c|c|}
\hline & Name of Program & Flood Management Services Program \\
\hline \multirow[t]{2}{*}{ Resilience Focus } & $\begin{array}{l}\text { Resilience is a Program } \\
\text { Priority }\end{array}$ & Y; Within the bounds of floodplain management. \\
\hline & $\begin{array}{l}\text { Mitigation, Planning, } \\
\text { Response, Recovery }\end{array}$ & $\begin{array}{l}\text { Mitigation, Planning, Recovery, Preparedness, } \\
\text { Response }\end{array}$ \\
\hline \multirow[t]{3}{*}{ Program Funding } & Total Funds Available & $\begin{array}{l}\$ 15 \mathrm{M} \text { FY20 appropriation, authorized up to } \\
\$ 50 \mathrm{M} / \text { year. }\end{array}$ \\
\hline & $\begin{array}{l}\text { Funding Limitations Per } \\
\text { Application }\end{array}$ & No explicit limits. \\
\hline & Cost Share Requirements & $\begin{array}{l}100 \% \text { federally funded for state, local, and other } \\
\text { governmental partners, though partners can } \\
\text { contribute funds to expand the scope of services to } \\
\text { be provided, and services can be provided on a } \\
\text { fully reimbursable basis to federal agency partners, } \\
\text { the private sector, or private citizens. }\end{array}$ \\
\hline \multirow{2}{*}{ Funding Timing } & Application Deadlines & Dependent on availability of funding. \\
\hline & Length of Benefit & Varies \\
\hline \multirow[t]{4}{*}{$\begin{array}{l}\text { Targeted } \\
\text { Applicants and } \\
\text { Recipients }\end{array}$} & Eligible Applicants & $\begin{array}{l}\text { State, local, tribal government partners (at } 100 \% \\
\text { federal cost) or federal government partners, } \\
\text { private sector, or private citizens on } 100 \% \\
\text { reimbursable basis. }\end{array}$ \\
\hline & Eligible Subapplicants & N/A \\
\hline & Eligible Recipients & $\begin{array}{l}\text { USACE district offices execute the work on behalf } \\
\text { of the local, state, or tribal government partners. }\end{array}$ \\
\hline & $\begin{array}{l}\text { Low-Income, Impoverished } \\
\text { Community Status } \\
\text { Prioritized }\end{array}$ & Dependent on area targeted by stakeholder. \\
\hline \multirow{3}{*}{$\begin{array}{l}\text { Hazard } \\
\text { Categorization }\end{array}$} & Hazards Included & Flood; Coastal \\
\hline & $\begin{array}{l}\text { Funding for Pre-disaster } \\
\text { Activities }\end{array}$ & $\bar{Y}$ \\
\hline & $\begin{array}{l}\text { Funding for Post-disaster } \\
\text { Activities }\end{array}$ & $\mathrm{Y}$ \\
\hline \multirow[t]{2}{*}{$\begin{array}{l}\text { Disaster } \\
\text { Declaration }\end{array}$} & $\begin{array}{l}\text { Disaster Declaration } \\
\text { Required }\end{array}$ & $\mathrm{N}$ \\
\hline & $\begin{array}{l}\text { Unusual Circumstances } \\
\text { Accepted }\end{array}$ & No Disaster Declaration is needed. \\
\hline
\end{tabular}




\begin{tabular}{|c|c|c|}
\hline \multirow[t]{3}{*}{ Projects Funded } & $\begin{array}{l}\text { Type of Facility or Land } \\
\text { Funded }\end{array}$ & $\begin{array}{l}\text { The authority does not include detailed planning or } \\
\text { design work; therefore, the types of facility or land } \\
\text { are not applicable. }\end{array}$ \\
\hline & Other Assistance Provided & Technical assistance \\
\hline & Project Types & $\begin{array}{l}\text { Obtaining, interpreting, or developing data about } \\
\text { flood sources and types, flood depths and water } \\
\text { surface elevations, floodwater velocity, flooding } \\
\text { extent and duration, flood frequency, and } \\
\text { obstruction of flood flows, as well as larger scale } \\
\text { "special studies" on all aspects of floodplain } \\
\text { management, including floodplain mapping, dam } \\
\text { break analyses, regulatory floodway studies, flood } \\
\text { warning and emergency preparedness, and flood } \\
\text { damage reduction studies. }\end{array}$ \\
\hline \multirow{3}{*}{$\begin{array}{l}\text { Financial } \\
\text { Application } \\
\text { Requirements }\end{array}$} & $\begin{array}{l}\text { Demonstrate Work is Cost } \\
\text { Effective }\end{array}$ & genotion \\
\hline & $\begin{array}{l}\text { Demonstrate No Available } \\
\text { Help Found Elsewhere }\end{array}$ & $\mathrm{N}$ \\
\hline & $\begin{array}{l}\text { Demonstrate Financial } \\
\text { History }\end{array}$ & $\mathrm{N}$ \\
\hline \multirow{10}{*}{$\begin{array}{l}\text { Other Application } \\
\text { Requirements \& } \\
\text { Criteria }\end{array}$} & $\begin{array}{l}\text { Existing Plan / Strategy } \\
\text { Required }\end{array}$ & $\mathrm{N}$ \\
\hline & $\begin{array}{l}\text { Special Requirements or } \\
\text { Benefits for Special Flood } \\
\text { Hazard Areas }\end{array}$ & $\mathrm{N}$ \\
\hline & $\begin{array}{l}\text { Participate / Good Standing } \\
\text { with National Flood } \\
\text { Insurance Program }\end{array}$ & $\mathrm{N}$ \\
\hline & Existing Insurance Required & $\mathrm{N}$ \\
\hline & $\begin{array}{l}\text { Demonstrate NEPA } \\
\text { Compliance }\end{array}$ & $\mathrm{N}$ \\
\hline & Public Outreach Prioritized & $\mathrm{Y}$ \\
\hline & $\begin{array}{l}\text { Building Code Adoption } \\
\text { Required }\end{array}$ & $\mathrm{N}$ \\
\hline & $\begin{array}{l}\text { Demonstrate Substantial } \\
\text { Damage }\end{array}$ & $\mathrm{N}$ \\
\hline & Other Criteria & NA \\
\hline & Additional Comments & $\begin{array}{l}\text { This program makes floodplain information } \\
\text { available to support local and state governments in } \\
\text { managing their floodplains. It does not include } \\
\text { detailed study, alternatives evaluation, or design } \\
\text { and construction support. To the extent practicable, } \\
\text { existing information is utilized to produce the } \\
\text { information and support local and state } \\
\text { governments. }\end{array}$ \\
\hline
\end{tabular}




\section{U.S. Department of Agriculture (USDA)}

\section{Farm Service Agency (FSA) - Emergency Forest Restoration}

Link to Program: https://www.fsa.usda.gov/programs-and-services/disaster-assistanceprogram/emergency-forest-restoration/

Description of Program: Provides payments to eligible owners of nonindustrial private forest (NIPF) land in order to carry out emergency measures to restore land damaged by a natural disaster.

\begin{tabular}{|c|c|c|}
\hline & Name of Program & FSA- Emergency Forest Restoration \\
\hline \multirow[t]{2}{*}{ Resilience Focus } & $\begin{array}{l}\text { Resilience is a Program } \\
\text { Priority }\end{array}$ & \\
\hline & $\begin{array}{l}\text { Mitigation, Planning, } \\
\text { Response, Recovery }\end{array}$ & Response, Recovery \\
\hline \multirow[t]{3}{*}{ Program Funding } & Total Funds Available & $\$ 391,838,700$ as of as of July 31,2020 \\
\hline & $\begin{array}{l}\text { Funding Limitations Per } \\
\text { Application }\end{array}$ & $\begin{array}{l}\text { Cost share approval amount that exceeds } \$ 125,000 \\
\text { requires State Committee approval; amounts } \\
\text { exceeding } \$ 250,000 \text { require National office } \\
\text { approval. }\end{array}$ \\
\hline & Cost Share Requirements & $\begin{array}{l}\text { Up to } 75 \% \text { Fed. cost share for forest restoration } \\
\text { practices }\end{array}$ \\
\hline \multirow[t]{2}{*}{ Funding Timing } & Application Deadlines & $\begin{array}{l}\text { After a natural disaster event, County FSA } \\
\text { Committees establish enrollment periods, usually } \\
\text { lasting } 30 \text { to } 60 \text { days. }\end{array}$ \\
\hline & Length of Benefit & $\begin{array}{l}\text { Participants typically have up to } 24 \text { months to } \\
\text { perform and report restoration practices }\end{array}$ \\
\hline \multirow{4}{*}{$\begin{array}{l}\text { Targeted } \\
\text { Applicants and } \\
\text { Recipients }\end{array}$} & Eligible Applicants & legal entity; Individual \\
\hline & Eligible Subapplicants & $\mathrm{N}$ \\
\hline & Eligible Recipients & legal entity; Individual \\
\hline & $\begin{array}{l}\text { Low-Income, Impoverished } \\
\text { Community Status } \\
\text { Prioritized }\end{array}$ & $\mathrm{n} / \mathrm{a}$ \\
\hline \multirow[t]{3}{*}{$\begin{array}{l}\text { Hazard } \\
\text { Categorization }\end{array}$} & Hazards Included & $\begin{array}{l}\text { Natural disaster events: fire, flood, hurricane, } \\
\text { severe snowstorm, tornado }\end{array}$ \\
\hline & $\begin{array}{l}\text { Funding for Pre-disaster } \\
\text { Activities }\end{array}$ & $\mathrm{N}$ \\
\hline & $\begin{array}{l}\text { Funding for Post-disaster } \\
\text { Activities }\end{array}$ & $\mathrm{Y}$ \\
\hline \multirow[t]{2}{*}{$\begin{array}{l}\text { Disaster } \\
\text { Declaration }\end{array}$} & $\begin{array}{l}\text { Disaster Declaration } \\
\text { Required }\end{array}$ & $\mathrm{N}$ \\
\hline & $\begin{array}{l}\text { Unusual Circumstances } \\
\text { Accepted }\end{array}$ & $\bar{Y}$ \\
\hline \multirow[t]{3}{*}{ Projects Funded } & $\begin{array}{l}\text { Type of Facility or Land } \\
\text { Funded }\end{array}$ & Private \\
\hline & Other Assistance Provided & \\
\hline & Project Types & $\begin{array}{l}\text { Restoration assistance for private, non-industrial } \\
\text { forest land }\end{array}$ \\
\hline \multirow{3}{*}{$\begin{array}{l}\text { Financial } \\
\text { Application } \\
\text { Requirements }\end{array}$} & $\begin{array}{l}\text { Demonstrate Work is Cost } \\
\text { Effective }\end{array}$ & $\bar{Y}$ \\
\hline & $\begin{array}{l}\text { Demonstrate No Available } \\
\text { Help Found Elsewhere }\end{array}$ & $\mathrm{n} / \mathrm{a}$ \\
\hline & $\begin{array}{l}\text { Demonstrate Financial } \\
\text { History }\end{array}$ & $\mathrm{N}$ \\
\hline
\end{tabular}




\begin{tabular}{|c|c|c|}
\hline \multirow{9}{*}{$\begin{array}{l}\text { Other Application } \\
\text { Requirements \& } \\
\text { Criteria }\end{array}$} & $\begin{array}{l}\text { Existing Plan / Strategy } \\
\text { Required }\end{array}$ & $\mathrm{N}$ \\
\hline & $\begin{array}{l}\text { Special Requirements or } \\
\text { Benefits for Special Flood } \\
\text { Hazard Areas }\end{array}$ & $\mathrm{N}$ \\
\hline & $\begin{array}{l}\text { Participate / Good Standing } \\
\text { with National Flood } \\
\text { Insurance Program }\end{array}$ & $\mathrm{N}$ \\
\hline & Existing Insurance Required & $\mathrm{N}$ \\
\hline & $\begin{array}{l}\text { Demonstrate NEPA } \\
\text { Compliance }\end{array}$ & $\mathrm{Y}$ \\
\hline & Public Outreach Prioritized & $\mathrm{N}$ \\
\hline & $\begin{array}{l}\text { Building Code Adoption } \\
\text { Required }\end{array}$ & $\mathrm{N}$ \\
\hline & $\begin{array}{l}\text { Demonstrate Substantial } \\
\text { Damage }\end{array}$ & $\bar{Y}$ \\
\hline & Other Criteria & $\begin{array}{l}\text { Only applies to owners of nonindustrial private } \\
\text { forest; } \\
\text { Disaster must harm the natural resources on the } \\
\text { land and } \\
\text { significantly affect future land use }\end{array}$ \\
\hline
\end{tabular}




\section{FSA - Emergency Conservation Program}

Link to Program: https://www.fsa.usda.gov/programs-and-services/conservation-

programs/emergency-conservation/index

Description of Program: Provides emergency funding and technical assistance to farmers and ranchers to rehabilitate farmland damaged by natural disasters and to implement emergency water conservation measures in periods of severe drought.

\begin{tabular}{|c|c|c|}
\hline & Name of Program & FSA - Emergency Conservation \\
\hline \multirow[t]{2}{*}{ Resilience Focus } & $\begin{array}{l}\text { Resilience is a Program } \\
\text { Priority }\end{array}$ & \\
\hline & $\begin{array}{l}\text { Mitigation, Planning, } \\
\text { Response, Recovery }\end{array}$ & Response, Recovery \\
\hline \multirow[t]{3}{*}{ Program Funding } & Total Funds Available & $\$ 375,913,200$ as of July 31,2020 \\
\hline & $\begin{array}{l}\text { Funding Limitations Per } \\
\text { Application }\end{array}$ & $\begin{array}{l}\text { Cost share approval amount that exceeds } \$ 125,000 \\
\text { requires State Committee approval; amounts } \\
\text { exceeding } \$ 250,000 \text { requires National office } \\
\text { approval." }\end{array}$ \\
\hline & Cost Share Requirements & $\begin{array}{l}\text { Up to } 75 \% \text { Fed. cost share for farmland restoration } \\
\text { practices; up to } 90 \% \text { for limited resource, SDA, or } \\
\text { beginning farmers and ranchers }\end{array}$ \\
\hline \multirow[t]{2}{*}{ Funding Timing } & Application Deadlines & $\begin{array}{l}\text { After a natural disaster event, County FSA } \\
\text { Committees establish enrollment periods, usually } \\
\text { lasting } 30 \text { to } 60 \text { days. }\end{array}$ \\
\hline & Length of Benefit & $\begin{array}{l}\text { Applicants have } 6 \text { months to complete the } \\
\text { restoration practices with the possibility of an } \\
\text { additional } 2 \text { six-month extensions for a total of } 18 \\
\text { months. }\end{array}$ \\
\hline \multirow{4}{*}{$\begin{array}{l}\text { Targeted } \\
\text { Applicants and } \\
\text { Recipients }\end{array}$} & Eligible Applicants & legal entity; Individual \\
\hline & Eligible Subapplicants & $\mathrm{N}$ \\
\hline & Eligible Recipients & legal entity; Individual \\
\hline & $\begin{array}{l}\text { Low-Income, Impoverished } \\
\text { Community Status } \\
\text { Prioritized }\end{array}$ & $\mathrm{n} / \mathrm{a}$ \\
\hline \multirow[t]{3}{*}{$\begin{array}{l}\text { Hazard } \\
\text { Categorization }\end{array}$} & Hazards Included & $\begin{array}{l}\text { Natural disaster events: drought, fire, flood, } \\
\text { hurricane, severe snowstorm, tornado }\end{array}$ \\
\hline & $\begin{array}{l}\text { Funding for Pre-disaster } \\
\text { Activities }\end{array}$ & $\mathrm{N}$ \\
\hline & $\begin{array}{l}\text { Funding for Post-disaster } \\
\text { Activities }\end{array}$ & $\mathrm{Y}$ \\
\hline \multirow[t]{2}{*}{$\begin{array}{l}\text { Disaster } \\
\text { Declaration }\end{array}$} & $\begin{array}{l}\text { Disaster Declaration } \\
\text { Required }\end{array}$ & $\mathrm{N}$ \\
\hline & $\begin{array}{l}\text { Unusual Circumstances } \\
\text { Accepted }\end{array}$ & $\mathrm{Y}$ \\
\hline \multirow[t]{3}{*}{ Projects Funded } & $\begin{array}{l}\text { Type of Facility or Land } \\
\text { Funded }\end{array}$ & Private \\
\hline & Other Assistance Provided & $\begin{array}{l}\text { Up to } 25 \% \text { advance payment available for fencing } \\
\text { restoration }\end{array}$ \\
\hline & Project Types & $\begin{array}{l}\text { Rehabilitate farmland post disaster or implement } \\
\text { emergency water conservation measures during } \\
\text { severe drought }\end{array}$ \\
\hline \multirow{2}{*}{$\begin{array}{l}\text { Financial } \\
\text { Application } \\
\text { Requirements }\end{array}$} & $\begin{array}{l}\text { Demonstrate Work is Cost } \\
\text { Effective }\end{array}$ & $\mathrm{Y}$ \\
\hline & $\begin{array}{l}\text { Demonstrate No Available } \\
\text { Help Found Elsewhere }\end{array}$ & $\mathrm{n} / \mathrm{a}$ \\
\hline
\end{tabular}




\begin{tabular}{|l|l|l|}
\hline & $\begin{array}{l}\text { Demonstrate Financial } \\
\text { History }\end{array}$ & $\mathrm{N}$ \\
\hline $\begin{array}{l}\text { Other Application } \\
\text { Requirements \& } \\
\text { Criteria }\end{array}$ & $\begin{array}{l}\text { Existing Plan / Strategy } \\
\text { Required }\end{array}$ & $\mathrm{N}$ \\
\cline { 2 - 3 } & $\begin{array}{l}\text { Special Requirements or } \\
\text { Benefits for Special Flood } \\
\text { Hazard Areas }\end{array}$ & $\mathrm{N}$ \\
\cline { 2 - 3 } & $\begin{array}{l}\text { Participate / Good Standing } \\
\text { with National Flood } \\
\text { Insurance Program }\end{array}$ & $\mathrm{N}$ \\
\cline { 2 - 3 } & Existing Insurance Required & $\mathrm{N}$ \\
\cline { 2 - 3 } & $\begin{array}{l}\text { Demonstrate NEPA } \\
\text { Compliance }\end{array}$ & $\mathrm{Y}$ \\
\cline { 2 - 3 } & Public Outreach Prioritized & $\mathrm{N}$ \\
\cline { 2 - 3 } & $\begin{array}{l}\text { Building Code Adoption } \\
\text { Required }\end{array}$ & $\mathrm{N}$ \\
\cline { 2 - 3 } & $\begin{array}{l}\text { Demonstrate Substantial } \\
\text { Damage }\end{array}$ & $\mathrm{Y}$ \\
\cline { 2 - 3 } & Other Criteria & $\begin{array}{l}\text { Eligible land includes commercial farming; growing } \\
\text { nursery stock or Christmas tree plantations; Grazing } \\
\text { for commercial livestock production; and } \\
\text { conservation structures, such as waterways, } \\
\text { terraces, diversions and windbreaks }\end{array}$ \\
\hline & & \\
\hline
\end{tabular}




\section{FSA - Emergency Loans for Farms}

Link to Program: https://www.fsa.usda.gov/programs-and-services/farm-loan-

programs/emergency-farm-loans/index

Description of Program: Help eligible farmers and ranchers rebuild and recover from sustained losses from a tornado, flood, drought, or quarantine by providing loans

\begin{tabular}{|c|c|c|}
\hline & Name of Program & FSA - Emergency Loans for Farms \\
\hline \multirow[t]{2}{*}{ Resilience Focus } & $\begin{array}{l}\text { Resilience is a Program } \\
\text { Priority }\end{array}$ & \\
\hline & $\begin{array}{l}\text { Mitigation, Planning, } \\
\text { Response, Recovery }\end{array}$ & Response, Recovery \\
\hline \multirow[t]{3}{*}{ Program Funding } & Total Funds Available & \\
\hline & $\begin{array}{l}\text { Funding Limitations Per } \\
\text { Application }\end{array}$ & $\$ 500,000$ max loan \\
\hline & Cost Share Requirements & No matching requirements \\
\hline \multirow[t]{2}{*}{ Funding Timing } & Application Deadlines & $\begin{array}{l}8 \text { months within county's disaster or quarantine } \\
\text { designation date }\end{array}$ \\
\hline & Length of Benefit & $\begin{array}{l}\text { 1-7 years for non-real estate losses, } 20 \text { years for } \\
\text { special circumstances; } 30 \text { years for real estate, } 40 \\
\text { years for special circumstances }\end{array}$ \\
\hline \multirow{4}{*}{$\begin{array}{l}\text { Targeted } \\
\text { Applicants and } \\
\text { Recipients }\end{array}$} & Eligible Applicants & Family farm operators \\
\hline & Eligible Subapplicants & $\mathrm{N}$ \\
\hline & Eligible Recipients & Family farm operators \\
\hline & $\begin{array}{l}\text { Low-Income, Impoverished } \\
\text { Community Status } \\
\text { Prioritized }\end{array}$ & $\mathrm{N} / \mathrm{A}$ \\
\hline \multirow{3}{*}{$\begin{array}{l}\text { Hazard } \\
\text { Categorization }\end{array}$} & Hazards Included & All \\
\hline & $\begin{array}{l}\text { Funding for Pre-disaster } \\
\text { Activities }\end{array}$ & $\mathrm{N}$ \\
\hline & $\begin{array}{l}\text { Funding for Post-disaster } \\
\text { Activities }\end{array}$ & $\mathrm{Y}$ \\
\hline \multirow[t]{2}{*}{$\begin{array}{l}\text { Disaster } \\
\text { Declaration }\end{array}$} & $\begin{array}{l}\text { Disaster Declaration } \\
\text { Required }\end{array}$ & Y; President or USDA \\
\hline & $\begin{array}{l}\text { Unusual Circumstances } \\
\text { Accepted }\end{array}$ & $\mathrm{N}$ \\
\hline \multirow[t]{3}{*}{ Projects Funded } & $\begin{array}{l}\text { Type of Facility or Land } \\
\text { Funded }\end{array}$ & Private \\
\hline & Other Assistance Provided & $\begin{array}{l}\text { Y; pay essential family living expenses; refinance } \\
\text { certain debts }\end{array}$ \\
\hline & Project Types & $\begin{array}{l}\text { Facilitate restoration and recovery of property and } \\
\text { continuation of operations during farm disruptions } \\
\text { due to natural disaster or quarantine (e.g., restore or } \\
\text { replace essential property; pay for production costs } \\
\text { in disaster year; reorganize farming operation) }\end{array}$ \\
\hline \multirow{3}{*}{$\begin{array}{l}\text { Financial } \\
\text { Application } \\
\text { Requirements }\end{array}$} & $\begin{array}{l}\text { Demonstrate Work is Cost } \\
\text { Effective }\end{array}$ & $\mathrm{N} / \mathrm{A}$ \\
\hline & $\begin{array}{l}\text { Demonstrate No Available } \\
\text { Help Found Elsewhere }\end{array}$ & Y; unable to receive credit from commercial sources \\
\hline & $\begin{array}{l}\text { Demonstrate Financial } \\
\text { History }\end{array}$ & $\begin{array}{l}\text { Y; acceptable credit history, provide collateral, have } \\
\text { repayment ability }\end{array}$ \\
\hline \multirow{2}{*}{$\begin{array}{l}\text { Other Application } \\
\text { Requirements \& } \\
\text { Criteria }\end{array}$} & $\begin{array}{l}\text { Existing Plan / Strategy } \\
\text { Required }\end{array}$ & $\mathrm{Y}$ \\
\hline & $\begin{array}{l}\text { Special Requirements or } \\
\text { Benefits for Special Flood } \\
\text { Hazard Areas }\end{array}$ & $\mathrm{Y}$ \\
\hline
\end{tabular}




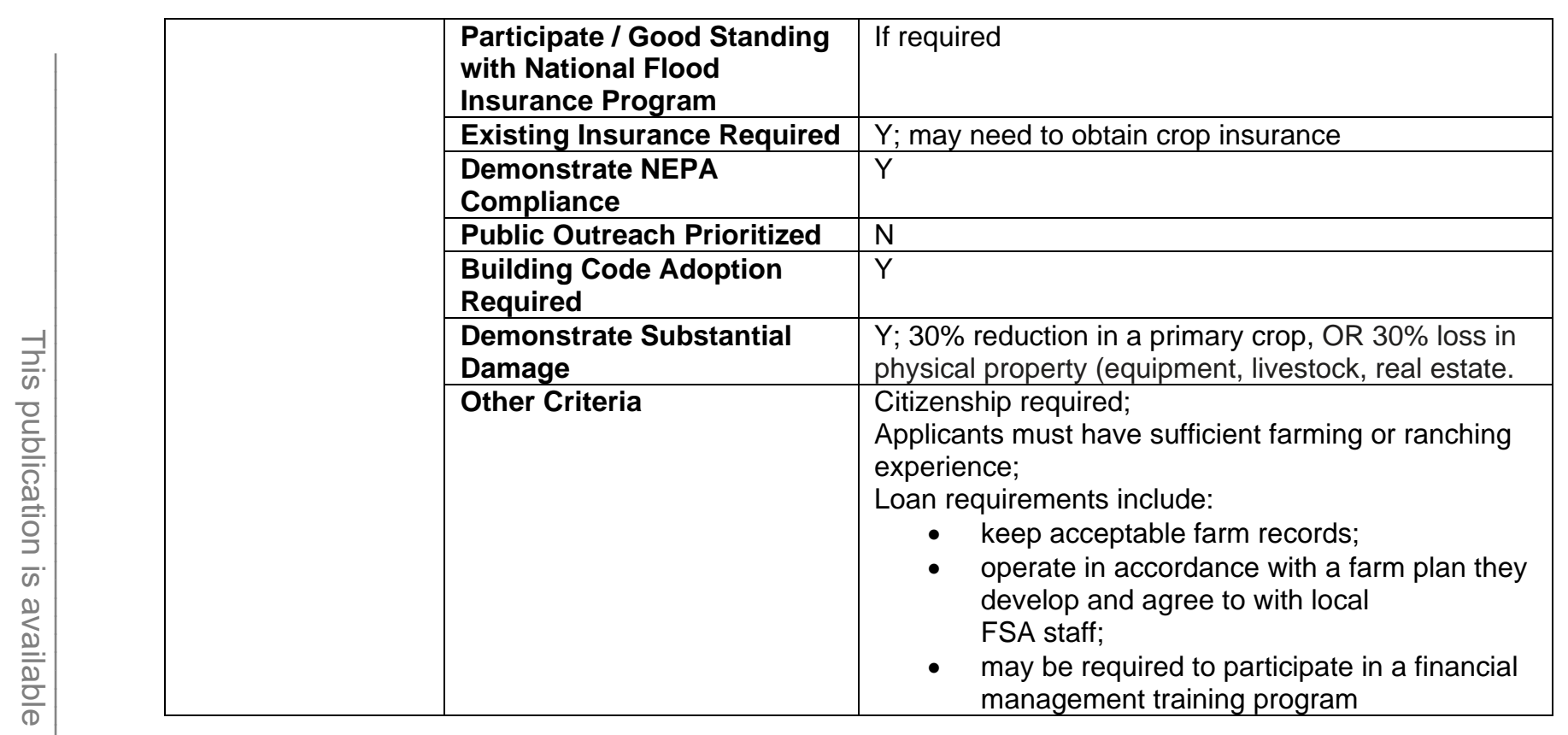


Forest Service (FS) - Volunteer Fire Assistance (also the Rural Fire Assistance Program)

Link to Program: https://www.fs.usda.gov/naspf/topics/fire/volunteer-fire-assistance

Description of Program: Administered by State Forestry agencies through 50-50 cost -sharing grants to local fire departments located in rural communities, VFA provides Federal financial, technical and other assistance in the organization, training and equipping of fire departments in rural areas

\begin{tabular}{|c|c|c|}
\hline & Name of Program & FS - Rural Fire Capacity Program \\
\hline \multirow[t]{2}{*}{ Resilience Focus } & $\begin{array}{l}\text { Resilience is a Program } \\
\text { Priority }\end{array}$ & \\
\hline & $\begin{array}{l}\text { Mitigation, Planning, } \\
\text { Response, Recovery }\end{array}$ & Mitigation and response \\
\hline \multirow[t]{3}{*}{ Program Funding } & Total Funds Available & \\
\hline & $\begin{array}{l}\text { Funding Limitations Per } \\
\text { Application }\end{array}$ & $\begin{array}{l}\text { grants are on the order of up to } \$ 5000 \text { each } \\
\text { (depends on state) }\end{array}$ \\
\hline & Cost Share Requirements & $\begin{array}{l}50 \% \text { Fed cost share with the state or local fire } \\
\text { departments }\end{array}$ \\
\hline \multirow[t]{2}{*}{ Funding Timing } & Application Deadlines & \\
\hline & Length of Benefit & \\
\hline \multirow{4}{*}{$\begin{array}{l}\text { Targeted } \\
\text { Applicants and } \\
\text { Recipients }\end{array}$} & Eligible Applicants & State \\
\hline & Eligible Subapplicants & $\begin{array}{l}\text { Local fire department, limited to } \\
\text { communities/municipalities with populations }<10,000\end{array}$ \\
\hline & Eligible Recipients & Local Fire agencies \\
\hline & $\begin{array}{l}\text { Low-Income, Impoverished } \\
\text { Community Status } \\
\text { Prioritized }\end{array}$ & Must be a rural community (pop. $\leq 10,000)$ \\
\hline \multirow{3}{*}{$\begin{array}{l}\text { Hazard } \\
\text { Categorization }\end{array}$} & Hazards Included & Fire \\
\hline & $\begin{array}{l}\text { Funding for Pre-disaster } \\
\text { Activities }\end{array}$ & $\mathrm{Y}$ \\
\hline & $\begin{array}{l}\text { Funding for Post-disaster } \\
\text { Activities }\end{array}$ & $\mathrm{N}$ \\
\hline \multirow[t]{2}{*}{$\begin{array}{l}\text { Disaster } \\
\text { Declaration }\end{array}$} & $\begin{array}{l}\text { Disaster Declaration } \\
\text { Required }\end{array}$ & $\mathrm{N}$ \\
\hline & $\begin{array}{l}\text { Unusual Circumstances } \\
\text { Accepted }\end{array}$ & $\mathrm{N}$ \\
\hline \multirow[t]{3}{*}{ Projects Funded } & $\begin{array}{l}\text { Type of Facility or Land } \\
\text { Funded }\end{array}$ & Public \\
\hline & Other Assistance Provided & \\
\hline & Project Types & $\begin{array}{l}\text { Fire prevention mitigation, support for fire } \\
\text { departments located in rural communities }\end{array}$ \\
\hline \multirow{3}{*}{$\begin{array}{l}\text { Financial } \\
\text { Application } \\
\text { Requirements }\end{array}$} & $\begin{array}{l}\text { Demonstrate Work is Cost } \\
\text { Effective }\end{array}$ & \\
\hline & $\begin{array}{l}\text { Demonstrate No Available } \\
\text { Help Found Elsewhere }\end{array}$ & \\
\hline & $\begin{array}{l}\text { Demonstrate Financial } \\
\text { History }\end{array}$ & \\
\hline \multirow{2}{*}{$\begin{array}{l}\text { Other Application } \\
\text { Requirements \& } \\
\text { Criteria }\end{array}$} & $\begin{array}{l}\text { Existing Plan / Strategy } \\
\text { Required }\end{array}$ & \\
\hline & $\begin{array}{l}\text { Special Requirements or } \\
\text { Benefits for Special Flood } \\
\text { Hazard Areas }\end{array}$ & \\
\hline
\end{tabular}




\begin{tabular}{|c|c|c|c|}
\hline & & $\begin{array}{l}\text { Participate / Good Standing } \\
\text { with National Flood } \\
\text { Insurance Program }\end{array}$ & \\
\hline & & Existing Insurance Required & \\
\hline & & $\begin{array}{l}\text { Demonstrate NEPA } \\
\text { Compliance }\end{array}$ & \\
\hline & & Public Outreach Prioritized & \\
\hline & & $\begin{array}{l}\text { Building Code Adoption } \\
\text { Required }\end{array}$ & \\
\hline & & $\begin{array}{l}\text { Demonstrate Substantial } \\
\text { Damage }\end{array}$ & \\
\hline & & Other Criteria & $\begin{array}{l}\text { VFA managed by State Forestry Agency, } \\
\text { requirements vary by state }\end{array}$ \\
\hline
\end{tabular}




\section{FS - Wildland Fire Management}

\section{Link to Program: https://fas.org/sgp/crs/misc/R45005.pdf}

Description of Program: Prevention, detection, response, and recovery related to fires that begin on federal lands by engaging in activities such as preparedness, suppression, fuel reduction, and site rehabilitation, among others. Appropriations go towards USDA FS and Department of the Interior.

\begin{tabular}{|c|c|c|}
\hline & Name of Program & FS - Wildland Fire Management \\
\hline \multirow[t]{2}{*}{ Resilience Focus } & $\begin{array}{l}\text { Resilience is a Program } \\
\text { Priority }\end{array}$ & \\
\hline & $\begin{array}{l}\text { Mitigation, Planning, } \\
\text { Response, Recovery }\end{array}$ & Mitigation, Response, Recovery \\
\hline \multirow[t]{3}{*}{ Program Funding } & Total Funds Available & \\
\hline & $\begin{array}{l}\text { Funding Limitations Per } \\
\text { Application }\end{array}$ & Total WFM Account: $\$ 390 M$ for FY 2017 \\
\hline & Cost Share Requirements & \\
\hline \multirow[t]{2}{*}{ Funding Timing } & Application Deadlines & \\
\hline & Length of Benefit & \\
\hline \multirow{4}{*}{$\begin{array}{l}\text { Targeted } \\
\text { Applicants and } \\
\text { Recipients }\end{array}$} & Eligible Applicants & \\
\hline & Eligible Subapplicants & \\
\hline & Eligible Recipients & \\
\hline & $\begin{array}{l}\text { Low-Income, Impoverished } \\
\text { Community Status } \\
\text { Prioritized }\end{array}$ & \\
\hline \multirow{3}{*}{$\begin{array}{l}\text { Hazard } \\
\text { Categorization }\end{array}$} & Hazards Included & \\
\hline & $\begin{array}{l}\text { Funding for Pre-disaster } \\
\text { Activities }\end{array}$ & Fire \\
\hline & $\begin{array}{l}\text { Funding for Post-disaster } \\
\text { Activities }\end{array}$ & $\mathrm{Y}$ \\
\hline \multirow[t]{2}{*}{$\begin{array}{l}\text { Disaster } \\
\text { Declaration }\end{array}$} & $\begin{array}{l}\text { Disaster Declaration } \\
\text { Required }\end{array}$ & $\mathrm{N}$ \\
\hline & $\begin{array}{l}\text { Unusual Circumstances } \\
\text { Accepted }\end{array}$ & $\mathrm{N}$ \\
\hline \multirow[t]{3}{*}{ Projects Funded } & $\begin{array}{l}\text { Type of Facility or Land } \\
\text { Funded }\end{array}$ & $\mathrm{N}$ \\
\hline & Other Assistance Provided & \\
\hline & Project Types & Y; fire science and research \\
\hline \multirow[t]{3}{*}{$\begin{array}{l}\text { Financial } \\
\text { Application } \\
\text { Requirements }\end{array}$} & $\begin{array}{l}\text { Demonstrate Work is Cost } \\
\text { Effective }\end{array}$ & $\begin{array}{l}\text { Fire prevention, readiness, wildfire response, fuels } \\
\text { management, post-fire rehabilitation, facilities, fire } \\
\text { science and research }\end{array}$ \\
\hline & $\begin{array}{l}\text { Demonstrate No Available } \\
\text { Help Found Elsewhere }\end{array}$ & \\
\hline & $\begin{array}{l}\text { Demonstrate Financial } \\
\text { History }\end{array}$ & \\
\hline \multirow{4}{*}{$\begin{array}{l}\text { Other Application } \\
\text { Requirements \& } \\
\text { Criteria }\end{array}$} & $\begin{array}{l}\text { Existing Plan / Strategy } \\
\text { Required }\end{array}$ & \\
\hline & $\begin{array}{l}\text { Special Requirements or } \\
\text { Benefits for Special Flood } \\
\text { Hazard Areas }\end{array}$ & \\
\hline & $\begin{array}{l}\text { Participate / Good Standing } \\
\text { with National Flood } \\
\text { Insurance Program }\end{array}$ & \\
\hline & Existing Insurance Required & \\
\hline
\end{tabular}




\begin{tabular}{|l|l|l|}
\hline & Demonstrate NEPA & \\
Compliance & \\
\cline { 2 - 3 } & Public Outreach Prioritized & \\
\cline { 2 - 3 } & Building Code Adoption & \\
Required & \\
\hline & $\begin{array}{l}\text { Demonstrate Substantial } \\
\text { Damage }\end{array}$ & \\
\hline & Other Criteria & \\
\hline
\end{tabular}




\section{FS - State Fire Assistance (SFA)}

Link to Program: https://www.fs.usda.gov/naspf/topics/fire/state-fire-assistance-sfa;

https://www.fs.usda.gov/detail/r4/communityforests/?cid=fsbdev3_015984

Description of Program: The State Fire Assistance Program provides financial and technical support directly to the states, to enhance firefighting capacity, support community-based hazard mitigation, and expand outreach and education to homeowners and communities concerning fire prevention.

\begin{tabular}{|c|c|c|}
\hline & Name of Program & FS - State Fire Assistance \\
\hline \multirow[t]{2}{*}{ Resilience Focus } & $\begin{array}{l}\text { Resilience is a Program } \\
\text { Priority }\end{array}$ & \\
\hline & $\begin{array}{l}\text { Mitigation, Planning, } \\
\text { Response, Recovery }\end{array}$ & Mitigation \\
\hline \multirow[t]{3}{*}{ Program Funding } & Total Funds Available & \\
\hline & $\begin{array}{l}\text { Funding Limitations Per } \\
\text { Application }\end{array}$ & \\
\hline & Cost Share Requirements & \\
\hline \multirow{2}{*}{ Funding Timing } & Application Deadlines & $50 \%$ Fed cost share with the state \\
\hline & Length of Benefit & \\
\hline \multirow{4}{*}{$\begin{array}{l}\text { Targeted } \\
\text { Applicants and } \\
\text { Recipients }\end{array}$} & Eligible Applicants & \\
\hline & Eligible Subapplicants & State \\
\hline & Eligible Recipients & \\
\hline & $\begin{array}{l}\text { Low-Income, Impoverished } \\
\text { Community Status } \\
\text { Prioritized }\end{array}$ & Local Fire agencies \\
\hline \multirow{3}{*}{$\begin{array}{l}\text { Hazard } \\
\text { Categorization }\end{array}$} & Hazards Included & \\
\hline & $\begin{array}{l}\text { Funding for Pre-disaster } \\
\text { Activities }\end{array}$ & Fire \\
\hline & $\begin{array}{l}\text { Funding for Post-disaster } \\
\text { Activities }\end{array}$ & $\mathrm{Y}$ \\
\hline \multirow[t]{2}{*}{$\begin{array}{l}\text { Disaster } \\
\text { Declaration }\end{array}$} & $\begin{array}{l}\text { Disaster Declaration } \\
\text { Required }\end{array}$ & $\mathrm{N}$ \\
\hline & $\begin{array}{l}\text { Unusual Circumstances } \\
\text { Accepted }\end{array}$ & $\mathrm{N}$ \\
\hline \multirow[t]{3}{*}{ Projects Funded } & $\begin{array}{l}\text { Type of Facility or Land } \\
\text { Funded }\end{array}$ & $\mathrm{N}$ \\
\hline & Other Assistance Provided & Non-Federal Lands \\
\hline & Project Types & $\mathrm{Y}$; training of local firefighters \\
\hline \multirow{3}{*}{$\begin{array}{l}\text { Financial } \\
\text { Application } \\
\text { Requirements }\end{array}$} & $\begin{array}{l}\text { Demonstrate Work is Cost } \\
\text { Effective }\end{array}$ & $\begin{array}{l}\text { Fire management, mitigation, suppression, and } \\
\text { prevention }\end{array}$ \\
\hline & $\begin{array}{l}\text { Demonstrate No Available } \\
\text { Help Found Elsewhere }\end{array}$ & \\
\hline & $\begin{array}{l}\text { Demonstrate Financial } \\
\text { History }\end{array}$ & \\
\hline \multirow{4}{*}{$\begin{array}{l}\text { Other Application } \\
\text { Requirements \& } \\
\text { Criteria }\end{array}$} & $\begin{array}{l}\text { Existing Plan / Strategy } \\
\text { Required }\end{array}$ & \\
\hline & $\begin{array}{l}\text { Special Requirements or } \\
\text { Benefits for Special Flood } \\
\text { Hazard Areas }\end{array}$ & \\
\hline & $\begin{array}{l}\text { Participate / Good Standing } \\
\text { with National Flood } \\
\text { Insurance Program }\end{array}$ & \\
\hline & Existing Insurance Required & \\
\hline
\end{tabular}




\begin{tabular}{|l|l|l|}
\hline & Demonstrate NEPA & \\
Compliance & \\
\cline { 2 - 3 } & Public Outreach Prioritized & \\
\cline { 2 - 3 } & $\begin{array}{l}\text { Building Code Adoption } \\
\text { Required }\end{array}$ & \\
\hline & $\begin{array}{l}\text { Demonstrate Substantial } \\
\text { Damage }\end{array}$ & \\
\hline & Other Criteria & \\
\hline
\end{tabular}


National Resources Conservation Service (NRCS) - Emergency Watershed Protection: Recovery Assistance

Link to Program:

https://www.nrcs.usda.gov/wps/portal/nrcs/main/national/programs/landscape/ewpp/

Description of Program: A federal emergency recovery program, the program helps local communities recover after a natural disaster. The program offers technical and financial assistance to help local communities relieve imminent threats to life and property caused by floods, fires, windstorms and other natural disasters that impair a watershed.

\begin{tabular}{|c|c|c|}
\hline & Name of Program & $\begin{array}{l}\text { NRCS - Emergency Watershed Protection: } \\
\text { Recovery Assistance }\end{array}$ \\
\hline \multirow[t]{2}{*}{ Resilience Focus } & $\begin{array}{l}\text { Resilience is a Program } \\
\text { Priority }\end{array}$ & \\
\hline & $\begin{array}{l}\text { Mitigation, Planning, } \\
\text { Response, Recovery }\end{array}$ & Response, Recovery \\
\hline \multirow[t]{3}{*}{ Program Funding } & Total Funds Available & \\
\hline & $\begin{array}{l}\text { Funding Limitations Per } \\
\text { Application }\end{array}$ & $\mathrm{N}$ \\
\hline & Cost Share Requirements & Up to $25 \%$ \\
\hline \multirow[t]{2}{*}{ Funding Timing } & Application Deadlines & $\begin{array}{l}8 \text { months within county's disaster or quarantine } \\
\text { designation date }\end{array}$ \\
\hline & Length of Benefit & $\begin{array}{l}1-7 \text { years for non-real estate losses, } 20 \text { years for } \\
\text { special circumstances; } 30 \text { years for real estate, } 40 \\
\text { years for special circumstances }\end{array}$ \\
\hline \multirow{4}{*}{$\begin{array}{l}\text { Targeted } \\
\text { Applicants and } \\
\text { Recipients }\end{array}$} & Eligible Applicants & Local Sponsors \\
\hline & Eligible Subapplicants & N/A \\
\hline & Eligible Recipients & Family farm operators \\
\hline & $\begin{array}{l}\text { Low-Income, Impoverished } \\
\text { Community Status } \\
\text { Prioritized }\end{array}$ & $\begin{array}{l}\text { Priority given to limited resource (low income) } \\
\text { communities }\end{array}$ \\
\hline \multirow{3}{*}{$\begin{array}{l}\text { Hazard } \\
\text { Categorization }\end{array}$} & Hazards Included & All \\
\hline & $\begin{array}{l}\text { Funding for Pre-disaster } \\
\text { Activities }\end{array}$ & $\mathrm{N}$ \\
\hline & $\begin{array}{l}\text { Funding for Post-disaster } \\
\text { Activities }\end{array}$ & $\mathrm{Y}$ \\
\hline \multirow[t]{2}{*}{$\begin{array}{l}\text { Disaster } \\
\text { Declaration }\end{array}$} & $\begin{array}{l}\text { Disaster Declaration } \\
\text { Required }\end{array}$ & Y; President or USDA \\
\hline & $\begin{array}{l}\text { Unusual Circumstances } \\
\text { Accepted }\end{array}$ & $\mathrm{N}$ \\
\hline \multirow[t]{3}{*}{ Projects Funded } & $\begin{array}{l}\text { Type of Facility or Land } \\
\text { Funded }\end{array}$ & Private \\
\hline & Other Assistance Provided & $\mathrm{N} / \mathrm{A}$ \\
\hline & Project Types & $\begin{array}{l}\text { Facilitate restoration and recovery of property and } \\
\text { continuation of operations during farm disruptions } \\
\text { due to natural disaster or quarantine. EWP-recovery } \\
\text { is not eligible for crop land. }\end{array}$ \\
\hline \multirow{4}{*}{$\begin{array}{l}\text { Financial } \\
\text { Application } \\
\text { Requirements }\end{array}$} & $\begin{array}{l}\text { Demonstrate Work is Cost } \\
\text { Effective }\end{array}$ & All measures must be economically defensible. \\
\hline & $\begin{array}{l}\text { Demonstrate No Available } \\
\text { Help Found Elsewhere }\end{array}$ & Y; unable to receive credit from commercial sources \\
\hline & $\begin{array}{l}\text { Demonstrate Financial } \\
\text { History }\end{array}$ & $\begin{array}{l}\text { Y; acceptable credit history, provide collateral, have } \\
\text { repayment ability }\end{array}$ \\
\hline & $\begin{array}{l}\text { Existing Plan / Strategy } \\
\text { Required }\end{array}$ & $\mathrm{Y}$ \\
\hline
\end{tabular}




\begin{tabular}{|c|c|c|}
\hline \multirow[t]{8}{*}{$\begin{array}{l}\text { Other Application } \\
\text { Requirements \& } \\
\text { Criteria }\end{array}$} & $\begin{array}{l}\text { Special Requirements or } \\
\text { Benefits for Special Flood } \\
\text { Hazard Areas }\end{array}$ & $\mathrm{Y}$ \\
\hline & $\begin{array}{l}\text { Participate / Good Standing } \\
\text { with National Flood } \\
\text { Insurance Program }\end{array}$ & If required \\
\hline & Existing Insurance Required & $\mathrm{Y}$ \\
\hline & $\begin{array}{l}\text { Demonstrate NEPA } \\
\text { Compliance }\end{array}$ & $\mathrm{Y}$ \\
\hline & Public Outreach Prioritized & $\mathrm{N}$ \\
\hline & $\begin{array}{l}\text { Building Code Adoption } \\
\text { Required }\end{array}$ & $\mathrm{Y}$ \\
\hline & $\begin{array}{l}\text { Demonstrate Substantial } \\
\text { Damage }\end{array}$ & $\mathrm{Y}$ \\
\hline & Other Criteria & \\
\hline
\end{tabular}




\section{NRCS - Watershed and Flood Prevention}

\section{Link to Program:}

https://www.nrcs.usda.gov/wps/portal/nrcs/main/national/programs/landscape/wfpo/

Description of Program: The Watershed Protection and Flood Prevention Program helps units of federal, state, local and tribal of government (project sponsors) protect and restore watersheds up to 250,000 acres. This program provides for cooperation between the Federal government and the states and their political subdivisions to work together to prevent erosion; floodwater and sediment damage; to further the conservation development, use and disposal of water; and to further the conservation and proper use of land in authorized watersheds.

\begin{tabular}{|c|c|c|}
\hline & Name of Program & NRCS - Watershed and Flood Prevention \\
\hline \multirow[t]{2}{*}{ Resilience Focus } & $\begin{array}{l}\text { Resilience is a Program } \\
\text { Priority }\end{array}$ & \\
\hline & $\begin{array}{l}\text { Mitigation, Planning, } \\
\text { Response, Recovery }\end{array}$ & Mitigation \\
\hline \multirow[t]{3}{*}{ Program Funding } & Total Funds Available & \\
\hline & $\begin{array}{l}\text { Funding Limitations Per } \\
\text { Application }\end{array}$ & $\mathrm{N}$ \\
\hline & Cost Share Requirements & Y; local share varies \\
\hline \multirow[t]{2}{*}{ Funding Timing } & Application Deadlines & $\mathrm{N}$ \\
\hline & Length of Benefit & Length of benefits vary; Some are up to 100 years \\
\hline \multirow{4}{*}{$\begin{array}{l}\text { Targeted } \\
\text { Applicants and } \\
\text { Recipients }\end{array}$} & Eligible Applicants & Local sponsors \\
\hline & Eligible Subapplicants & $\mathrm{N}$ \\
\hline & Eligible Recipients & Family farm operators \\
\hline & $\begin{array}{l}\text { Low-Income, Impoverished } \\
\text { Community Status } \\
\text { Prioritized }\end{array}$ & $\mathrm{N} / \mathrm{A}$ \\
\hline \multirow{3}{*}{$\begin{array}{l}\text { Hazard } \\
\text { Categorization }\end{array}$} & Hazards Included & All \\
\hline & $\begin{array}{l}\text { Funding for Pre-disaster } \\
\text { Activities }\end{array}$ & $\mathrm{Y}$ \\
\hline & $\begin{array}{l}\text { Funding for Post-disaster } \\
\text { Activities }\end{array}$ & $\mathrm{Y}$ \\
\hline \multirow[t]{2}{*}{$\begin{array}{l}\text { Disaster } \\
\text { Declaration }\end{array}$} & $\begin{array}{l}\text { Disaster Declaration } \\
\text { Required }\end{array}$ & $\mathrm{N}$ \\
\hline & $\begin{array}{l}\text { Unusual Circumstances } \\
\text { Accepted }\end{array}$ & $\mathrm{N}$ \\
\hline \multirow[t]{3}{*}{ Projects Funded } & $\begin{array}{l}\text { Type of Facility or Land } \\
\text { Funded }\end{array}$ & Private \\
\hline & Other Assistance Provided & $\mathrm{Y}$ \\
\hline & Project Types & $\begin{array}{l}\text { Facilitate restoration and recovery of property and } \\
\text { continuation of operations during farm disruptions } \\
\text { due to natural disaster or quarantine }\end{array}$ \\
\hline \multirow{4}{*}{$\begin{array}{l}\text { Financial } \\
\text { Application } \\
\text { Requirements }\end{array}$} & $\begin{array}{l}\text { Demonstrate Work is Cost } \\
\text { Effective }\end{array}$ & Y; All measures must be economically defensible. \\
\hline & $\begin{array}{l}\text { Demonstrate No Available } \\
\text { Help Found Elsewhere }\end{array}$ & Y; unable to receive credit from commercial sources \\
\hline & $\begin{array}{l}\text { Demonstrate Financial } \\
\text { History }\end{array}$ & $\begin{array}{l}\text { Y; acceptable credit history, provide collateral, have } \\
\text { repayment ability }\end{array}$ \\
\hline & $\begin{array}{l}\text { Existing Plan / Strategy } \\
\text { Required }\end{array}$ & $\mathrm{Y}$ \\
\hline
\end{tabular}




\begin{tabular}{|c|c|c|}
\hline \multirow[t]{8}{*}{$\begin{array}{l}\text { Other Application } \\
\text { Requirements \& } \\
\text { Criteria }\end{array}$} & $\begin{array}{l}\text { Special Requirements or } \\
\text { Benefits for Special Flood } \\
\text { Hazard Areas }\end{array}$ & $\bar{Y}$ \\
\hline & $\begin{array}{l}\text { Participate / Good Standing } \\
\text { with National Flood } \\
\text { Insurance Program }\end{array}$ & If required \\
\hline & Existing Insurance Required & $\bar{Y}$ \\
\hline & $\begin{array}{l}\text { Demonstrate NEPA } \\
\text { Compliance }\end{array}$ & $\mathrm{Y}$ \\
\hline & Public Outreach Prioritized & $\mathrm{N}$ \\
\hline & $\begin{array}{l}\text { Building Code Adoption } \\
\text { Required }\end{array}$ & $\bar{Y}$ \\
\hline & $\begin{array}{l}\text { Demonstrate Substantial } \\
\text { Damage }\end{array}$ & $\mathrm{Y}$ \\
\hline & Other Criteria & \\
\hline
\end{tabular}




\section{NRCS - Environmental Quality Incentives Program (EQIP)}

\section{Link to Program:}

https://www.nrcs.usda.gov/wps/portal/nrcs/main/national/programs/financial/eqip/

Description of Program: Provides financial and technical assistance to agricultural producers to address natural resource concerns and deliver environmental benefits such as improved water and air quality, conserved ground and surface water, increased soil health and reduced soil erosion and sedimentation, improved or created wildlife habitat, and mitigation against increasing weather volatility.

\begin{tabular}{|c|c|c|}
\hline & Name of Program & $\begin{array}{l}\text { NRCS - Environmental Quality Incentive } \\
\text { Program (EQIP) }\end{array}$ \\
\hline \multirow[t]{2}{*}{ Resilience Focus } & $\begin{array}{l}\text { Resilience is a Program } \\
\text { Priority }\end{array}$ & 9.5 \\
\hline & $\begin{array}{l}\text { Mitigation, Planning, } \\
\text { Response, Recovery }\end{array}$ & $\begin{array}{l}\text { Mitigation, Planning, Response, and Recovery for } \\
\text { individual private landowners }\end{array}$ \\
\hline \multirow[t]{3}{*}{ Program Funding } & Total Funds Available & $\$ 1.8$ Billion \\
\hline & $\begin{array}{l}\text { Funding Limitations Per } \\
\text { Application }\end{array}$ & $\begin{array}{l}\$ 450,000 \text { financial assistance per privately } \\
\text { owner/operator farm/ranch. }\end{array}$ \\
\hline & Cost Share Requirements & $\begin{array}{l}\text { Payment rates are offered, and vary by state from } \\
50 \% \text { to } 75 \% \text {, and up to } 90 \% \text { for historically } \\
\text { underserved collaborators }\end{array}$ \\
\hline \multirow[t]{2}{*}{ Funding Timing } & Application Deadlines & $\begin{array}{l}\text { Varies per state; State Conservationist determines } \\
\text { batching dates for applications; Applications can be } \\
\text { taken all year }\end{array}$ \\
\hline & Length of Benefit & $\begin{array}{l}\text { NRCS has over } 330 \text { conservation practices and } \\
\text { enhancements landowners can pursue. The benefits } \\
\text { range from } 1 \text {-year to } 25 \text {-years depending on the type } \\
\text { of practice installed. }\end{array}$ \\
\hline \multirow{4}{*}{$\begin{array}{l}\text { Targeted } \\
\text { Applicants and } \\
\text { Recipients }\end{array}$} & Eligible Applicants & Privately owned/operated farms/ranches \\
\hline & Eligible Subapplicants & $\begin{array}{l}\mathrm{Y} \text {, if part of a joint venture, LLC, or other type of farm } \\
\text { operation }\end{array}$ \\
\hline & Eligible Recipients & Privately owned or operated farm/ranches \\
\hline & $\begin{array}{l}\text { Low-Income, Impoverished } \\
\text { Community Status } \\
\text { Prioritized }\end{array}$ & $\begin{array}{l}\text { Historically Underserved }(\mathrm{HU}) \text { receive } 90 \% \text { financial } \\
\text { assistance rate. }\end{array}$ \\
\hline \multirow{3}{*}{$\begin{array}{l}\text { Hazard } \\
\text { Categorization }\end{array}$} & Hazards Included & All \\
\hline & $\begin{array}{l}\text { Funding for Pre-disaster } \\
\text { Activities }\end{array}$ & $\mathrm{Y}$, as noted above \\
\hline & $\begin{array}{l}\text { Funding for Post-disaster } \\
\text { Activities }\end{array}$ & $\begin{array}{l}\text { Y; recovery-limited to natural resource concerns and } \\
\text { eligible conservation practices }\end{array}$ \\
\hline \multirow[t]{2}{*}{$\begin{array}{l}\text { Disaster } \\
\text { Declaration }\end{array}$} & $\begin{array}{l}\text { Disaster Declaration } \\
\text { Required }\end{array}$ & Y; Presidential, Secretarial, or State Conservationist \\
\hline & $\begin{array}{l}\text { Unusual Circumstances } \\
\text { Accepted }\end{array}$ & $\mathrm{N}$ \\
\hline \multirow[t]{4}{*}{ Projects Funded } & $\begin{array}{l}\text { Type of Facility or Land } \\
\text { Funded }\end{array}$ & $\begin{array}{l}\text { Privately owned or operated } \\
\text { farms/ranches/woodlands }\end{array}$ \\
\hline & Other Assistance Provided & $\begin{array}{l}\text { Y; Eligible conservation practices that address a } \\
\text { natural resource concern and eligible conservation } \\
\text { practices }\end{array}$ \\
\hline & Project Types & $\begin{array}{l}\text { Animal mortality, clearing and snagging of debris in } \\
\text { waterbodies, obstruction removal, cover crops, } \\
\text { repairs to damaged conservation practices, etc., }\end{array}$ \\
\hline & $\begin{array}{l}\text { Demonstrate Work is Cost } \\
\text { Effective }\end{array}$ & $\mathrm{N} / \mathrm{A}$ \\
\hline
\end{tabular}




\begin{tabular}{|c|c|c|}
\hline \multirow{2}{*}{$\begin{array}{l}\text { Financial } \\
\text { Application } \\
\text { Requirements }\end{array}$} & $\begin{array}{l}\text { Demonstrate No Available } \\
\text { Help Found Elsewhere }\end{array}$ & $\begin{array}{l}\mathrm{N} \text {; Eligible conservation practices that meet a natural } \\
\text { resource concern }\end{array}$ \\
\hline & $\begin{array}{l}\text { Demonstrate Financial } \\
\text { History }\end{array}$ & $\begin{array}{l}\mathrm{N} ; \text { A percentage of the financial assistance will be } \\
\text { required from the farm owner or operator }\end{array}$ \\
\hline \multirow{9}{*}{$\begin{array}{l}\text { Other Application } \\
\text { Requirements \& } \\
\text { Criteria }\end{array}$} & $\begin{array}{l}\text { Existing Plan / Strategy } \\
\text { Required }\end{array}$ & $\begin{array}{l}\text { Y; or one developed for the natural resource concern } \\
\text { being addressed }\end{array}$ \\
\hline & $\begin{array}{l}\text { Special Requirements or } \\
\text { Benefits for Special Flood } \\
\text { Hazard Areas }\end{array}$ & $\begin{array}{l}\text { Y, application must be announced by State } \\
\text { Conservationist and posted on state NRCS website }\end{array}$ \\
\hline & $\begin{array}{l}\text { Participate / Good Standing } \\
\text { with National Flood } \\
\text { Insurance Program }\end{array}$ & If required \\
\hline & Existing Insurance Required & $\begin{array}{l}\mathrm{N} ; \text { not required to assistance from NRCS, but some } \\
\text { circumstances require coordination with RMA by the } \\
\text { client to determine payments most advantageous to } \\
\text { their operation }\end{array}$ \\
\hline & $\begin{array}{l}\text { Demonstrate NEPA } \\
\text { Compliance }\end{array}$ & $\begin{array}{l}\text { Y; each application undergoes a federal planning } \\
\text { process to include an accelerated NEPA evaluation } \\
\text { unique to NRCS }\end{array}$ \\
\hline & Public Outreach Prioritized & $\begin{array}{l}\text { Y; State Conservationists must proactively announce } \\
\text { opportunity for assistance }\end{array}$ \\
\hline & $\begin{array}{l}\text { Building Code Adoption } \\
\text { Required }\end{array}$ & $\begin{array}{l}\text { Y; many conservation practices will need to conform } \\
\text { to all federal, state, and local requirements. }\end{array}$ \\
\hline & $\begin{array}{l}\text { Demonstrate Substantial } \\
\text { Damage }\end{array}$ & $\begin{array}{l}\text { Y; resource concern must be documented by local } \\
\text { certified conservation planner }\end{array}$ \\
\hline & Other Criteria & $\begin{array}{l}\text { Eligible privately owned and operated farm/ranch; } \\
\text { Operate in accordance with a farm plan they develop } \\
\text { with local NRCS staff }\end{array}$ \\
\hline
\end{tabular}




\section{Appendix C. Descriptions of Variables in Program Database}

Table 1. Resilience Program Requirements

Financial Requirements: Applicant must meet some standard of financial or credit capacity in order to qualify.

Threshold Requirements: Applicant must meet one or more externally determined criteria. Compliance Requirements: Applicant must have taken actions to meet specified regulatory standards.

Planning Requirements: Applicant must have approved plans or a planning process in place prior to qualifying for a program

Coordination Requirements: Applicant must demonstrate that resources from other sources have been requested or obtained.

Program-Specific: Requirements that are not shared with other programs in the database or falling into other broad categories. This does not indicate an absence of requirements, just that a program's requirements are unique.

Table 2. Resilience Program Timing

Pre-event: before a disruption

Post-event: after a disruption

Table 3. Resilience Program Applicants

State: State government and State agencies

Community: The people and institutions in a particular area of unspecified size that share risk in the face of a hazard and a network of relationships that allows preparation and response. Communities can be represented by governmental or municipal entities; for the purposes of this study, communities exclude individual States, because States are specifically designated by many Federal programs as recipients of support in the form of block grants to be further disbursed. Communities can, however, be represented by a consortium with one or more State governments participating. Tribes can access community resources, but also have access to additional tribal-specific resources.

Tribe: Federally recognized tribal governments

Individual: A single person representing himself or herself

Non-Profit: A non-governmental organization that receives support from a Federal program to support community facilities, social institutions, or residents. When non-profit organizations receive Federal loans or grants to repair property or replace equipment they own, they are considered businesses for the purposes of this study.

Business: A company or corporation representing itself; not constrained by size. 
Table 4. Resilience Program Focus Areas

Infrastructure: Building, protecting, improving machinery and facilities (for example, buildings, roads, water, sewage, power) that enable the vital functions of a community's governance, public health, and economy; infrastructure can be publicly or privately owned.

Economy: Protection and recovery of fiscal, financial, and commercial activities within a community, including public expenditure, individual income and employment, and business activity

Environment: Management and restoration of natural resources promoting the resilience of a community

Training: Preparing community managers, leaders, and residents to respond to natural disasters or other disruptions of the community

Housing: Residential dwellings occupied by individuals and families

Equipment: Purchase or acquisition of equipment needed to improve a community's resilience in the face of natural disasters or other disruptions

Health: Help the residents of a community prepare for, cope with, and recover from the mental, physical, and other stresses experienced in the aftermath of a natural disaster or other disruption

Table 5. Resilience Program Hazards

\section{Flood}

Coastal: Spans a complex array of closely related hazards such as wind damage, flooding, and loss or movement of emergent land that are also a concern in non-coastal settings. Coastal programs address them as a suite of hazards that share a common cause and amplify each other's effects.

\section{Drought}

Wildfire

All: Unrestricted with respect to hazard type

Table 6. Aspects of Resilience

Planning: Support for carrying out a systematic process to develop executable strategic, operational, and/or community-based approaches to meet resilience objectives in the light of current and expected financial, environmental, and demographic conditions

Mitigation: Support for enhancing capabilities intended to reduce loss of life and property by lessening the impact of disasters, including community-wide risk reduction projects and improvement of the resilience of critical infrastructure and key resource lifelines

Response: Support to save lives, protect property and the environment, and meet basic human needs after an incident has occurred

Recovery: Support for capabilities necessary to assist communities affected by an incident to rebuild or enhance infrastructure systems and housing; restore health, social, and community services; promote economic development; and restore natural and cultural resources 


\section{Appendix D. Program Coding Table}

\begin{tabular}{|c|c|c|c|c|c|c|c|c|c|c|c|c|c|c|c|c|c|c|c|c|c|c|c|c|c|c|c|c|c|c|c|c|}
\hline & & \multicolumn{6}{|c|}{ Requirements } & \multicolumn{2}{|c|}{\begin{tabular}{|l||} 
Timing \\
\end{tabular}} & \multicolumn{6}{|c|}{ Applicants } & \multicolumn{8}{|c|}{ Focus } & \multicolumn{5}{|c|}{ Hazards } & \multicolumn{4}{|c|}{ Aspects } \\
\hline Agency & Program & & \begin{tabular}{|c|}
$\frac{n}{0}$ \\
$\frac{0}{0}$ \\
$\frac{5}{y}$ \\
$\frac{0}{5}$ \\
$F$ \\
\end{tabular} & 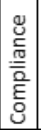 & 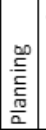 & 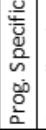 & 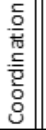 & 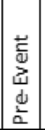 & 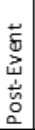 & 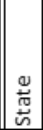 & 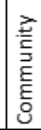 & 登 & 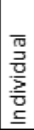 & 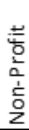 & 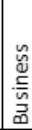 & & 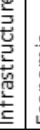 & . & 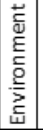 & 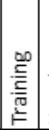 & 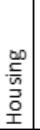 & 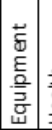 & 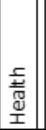 & $\bar{\varepsilon}$ & $\begin{array}{l} \\
0 \\
4 \\
\end{array}$ & 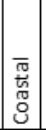 & 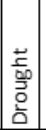 & 穴 & 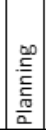 & & 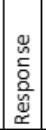 & 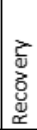 \\
\hline BIA & Tribal Resilience Program & 0 & 0 & 0 & 0 & 1 & 0 & 1 & 0 & 0 & 0 & 01 & $\underline{0}$ & ( & c & & 1 & 0 & 1 & 1 & 0 & 0 & 1 & 1 & 0 & 0 & 0 & 0 & 1 & 0 & 0 & 0 \\
\hline & & & & & & & & & & & & & & & & & & & & & & & & & & & & & 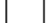 & & 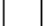 & \\
\hline DOE & ate Energy Program & & 0 & 1 & 1 & 0 & 0 & 1 & 1 & & $\underline{0}$ & 0 & 0 & & & & 1 & & 0 & 0 & 0 & 0 & 0 & 0 & 0 & 0 & 0 & 0 & 1 & 1 & 1 & 0 \\
\hline DOL & Disaster Unemployment & & & 0 & & & 00 & & 1 & 0 & 0 & t & & $\left.C_{1}\right)$ & 0 & & 0 & & 0 & 0 & 0 & 0 & 0 & & 0 & 0 & 0 & 0 & ( & & 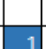 & 0 \\
\hline & & & & & & & & & & & & & & & & & & & & & & & & & & & & & & & -1 & \\
\hline DOT & $\begin{array}{l}\text { FHWA Federal-Aid Highway } \\
\text { Emergency Relief Program }\end{array}$ & & 1 & 0 & 0 & 0 & 0 & 0 & 1 & & & & 0 & & & & 1 & & 0 & 0 & 0 & & 0 & & & & 0 & 0 & 0 & 0 & 1 & 0 \\
\hline DOT & $\begin{array}{l}\text { FTA Public Transportation } \\
\text { Emergency Relief Program }\end{array}$ & & 1 & 1 & 0 & 0 & 0 & 0 & 1 & 1 & 1 & & 0 & & & & & 0 & 0 & 0 & 0 & & 0 & & & 0 & 0 & 0 & 0 & 0 & & 0 \\
\hline & & & & & & & & & & & & & & & & & & & & & & & & & & & & & & & & \\
\hline EDA & $\begin{array}{l}\text { Economic Adjustment Assistance } \\
\text { Grant }\end{array}$ & & 0 & 1 & 1 & 0 & 0 & 1. & 1 & 1 & 1 & & 0 & & & & 1 & 1 & 0 & 0 & 0 & & 0 & & & 0 & 0 & 0 & 1 & & 0 & 1 \\
\hline EDA & $\begin{array}{l}\text { Economic Development Disaster } \\
\text { Supplemental Funding }\end{array}$ & 1 & 1 & 1 & 1 & 0 & 0 & 0 & 1 & 1 & 1 & & 0 & & c & & 1 & 1 & 0 & 0 & 0 & & 0 & & & & 0 & 0 & 0 & & 0 & 1 \\
\hline EDA & $\begin{array}{l}\text { Economic Development Support } \\
\text { for Planning Organizations }\end{array}$ & & 0 & 0 & 0 & 0 & 0 & 1 & 1 & 1 & 1 & & 0 & & 0 & & 0 & 1 & 0 & 0 & 0 & & 0 & & & 0 & 0 & 0 & & & 0 & 0 \\
\hline EDA & $\begin{array}{l}\text { Investment for Public Works and } \\
\text { Economic Development Facilities }\end{array}$ & & 0 & 1 & 1 & 0 & 0 & 1 & 1 & 1 & 1 & & 0 & & & & 1 & 1 & & 0 & 0 & & 0 & 0 & & 0 & 0 & 0 & 0 & & 0 & 1 \\
\hline & & & & & & & & & & & & & & & & & & & & & & & & & & & & & & & & 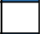 \\
\hline EPA & $\begin{array}{l}\text { SRF-State Revolving Fund (Clean } \\
\text { Water) }\end{array}$ & 1 & 0 & 0 & 0 & 0 & 0 & 1 & 1 & 1 & $\underline{0}$ & & 0 & & c & & 1 & 0 & 0 & 0 & 0 & & 0 & 0 & & 0 & 0 & 0 & 0 & & 0 & 1 \\
\hline EPA & $\begin{array}{l}\begin{array}{l}\text { SRF-State Revolving Fund } \\
\text { (Drinking Water) }\end{array} \\
\text { (Ding }\end{array}$ & & 0 & 0 & 0 & 0 & 0 & 1 & 1 & 1 & & & 0 & & & & 1 & 0 & 0 & 0 & 0 & & 0 & 0 & & & 0 & 0 & 0 & & 0 & 1 \\
\hline EPA & $\begin{array}{l}\text { Water Infrastructure Finance and } \\
\text { Innovation Act Program }\end{array}$ & & 0 & 0 & 0 & 0 & 0 & 1 & 1 & 1 & 1 & & 0 & & & & 1 & 0 & 0 & 0 & 0 & & 0 & 0 & & 0 & 1 & 0 & 0 & & 0 & 1 \\
\hline & & & & & & & & & & & & & & & & & & & & & & & & & & & & & & & & \\
\hline FEMA & Community Disaster Loan & 1 & 1 & 0 & 0 & 0 & 0 & 0 & 1 & 1 & 0 & 0 & 0 & ( & & & 0 & 1 & 0 & 0 & 0 & 0 & 0 & & 0 & 0 & 0 & 0 & 0 & 0 & 1 & 0 \\
\hline FEMA & Community Rating System & 1 & 0 & 1 & 0 & 0 & 0 & 0 & 1 & 0 & 1 & 0 & 0 & ( & & & 0 & 1 & 0 & 0 & 0 & 0 & 0 & 0 & 1 & 0 & 0 & 0 & 0 & 1 & 0 & 0 \\
\hline FEMA & Cora Brown Fund & 0 & 1 & 0 & 0 & 0 & 0 & 0 & 1 & 0 & 1 & 0 & 1 & 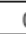 & 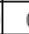 & & 0 & 1 & 0 & 0 & 0 & 0 & 1 & 1 & 0 & 0 & 0 & 0 & 0 & 0 & 1 & 0 \\
\hline FEMA & Fire Management Assistance & 1 & 0 & 0 & 0 & 0 & 0 & 1 & 0 & 1 & 0 & $\begin{array}{ll}0 \\
0\end{array}$ & 0 & - & & & 0 & 0 & 0 & 0 & 0 & 1 & 0 & 0 & 0 & 0 & 0 & 1 & 0 & 1 & 0 & 0 \\
\hline FEMA & Flood Mitigation Assistance & 1 & 0 & 1 & 1 & 0 & 0 & 1 & 0 & 1 & 1 & $1 \quad 1$ & $\underline{0}$ & c & ( & & 1 & 0 & 0 & 0 & 0 & 0 & 0 & 0 & 1 & 0 & 0 & 0 & 0 & 1 & 0 & 0 \\
\hline FEMA & Hazard Mitigation Grant Program & 1 & 1 & 1 & 1 & 0 & 0 & 0 & 1 & 1 & 1 & & 0 & ( & ( & & 1 & 0 & 0 & 0 & 0 & 0 & 0 & 1 & 0 & 0 & 0 & 0 & 0 & 1 & 0 & 1 \\
\hline FEMA & $\begin{array}{l}\text { Increased cost of Compliance } \\
\text { Coverage }\end{array}$ & 1 & 1 & 1 & 0 & 0 & 0 & 0 & 1 & 0 & 0 & & 1 & & & & 1 & o & 0 & 0 & 0 & 0 & 0 & 0 & & 0 & 0 & 0 & 0 & & 0 & 1 \\
\hline FEMA & Individual Assistance Grant & 1 & 1 & 0 & 0 & 0 & 0 & 0 & 1 & 1 & 1 & 1 & 1 & se & - & & 0 & 1 & 0 & 0 & 0 & 0 & 1 & 1 & 0 & 0 & 0 & 0 & 0 & 0 & 1 & 0 \\
\hline FEMA & $\begin{array}{l}\text { Individuals and Households } \\
\text { Program }\end{array}$ & 1 & 1 & 0 & 0 & 0 & 0 & 0 & A & 0 & 0 & & & & $c$ & & 0 & 1 & 0 & 0 & 1 & & 0 & & & 0 & 0 & 0 & 0 & 0 & & 0 \\
\hline FEMA & Pre-Event Mitigation Grant & 1 & 0 & 1 & 1 & 0 & 0 & 1 & 0 & 1 & 1 & 1 & 0 & ( & $\mathrm{c}$ & & 1 & 0 & 0 & 0 & 0 & 0 & 0 & 1 & 0 & 0 & 0 & 0 & 1 & 1 & 0 & 0 \\
\hline FEMA & Public Assistance Grant & 1 & 1 & 0 & 0 & 0 & 0 & 0 & 1 & 1 & 1 & & 0 & & C & & 1 & 0 & 0 & 0 & 0 & 0 & 0 & 1 & 0 & 0 & 0 & 0 & 0 & 0 & 1 & 0 \\
\hline & & & & & & & & & & & & & & & & & & & & & & & & & & & & & & & & \\
\hline HUD & $\begin{array}{l}\text { Community Development Block } \\
\text { Grant - Mitigation }\end{array}$ & 1 & 1 & 0 & 1 & 0 & 1 & 0 & 1 & 1 & & & 0 & & c & & 1 & 0 & 0 & 0 & 0 & 0 & 0 & 1 & & 0 & 0 & 0 & 0 & & 0 & 1 \\
\hline HUD & $\begin{array}{l}\text { Community Development Block } \\
\text { Grant Disaster - Recovery }\end{array}$ & 1 & 1 & 0 & 0 & 0 & 0 & 0 & 1 & 1 & 1 & & 0 & & c & & & 0 & & 0 & 0 & 0 & 0 & & & & 0 & 0 & 0 & 0 & 0 & 1 \\
\hline HUD & $\begin{array}{l}\text { Community Development Block } \\
\text { Grant }\end{array}$ & 1 & 1 & 0 & 0 & 0 & 0 & 1 & 1 & 1 & 1 & 0 & 0 & c & c & & 0 & 0 & 0 & 0 & & 0 & 0 & 0 & 0 & 0 & 0 & 0 & 0 & & 0 & 1 \\
\hline & & & & & & & & & & & & & & & & & & & & & & & & & & & & & & & & \\
\hline NOAA & Coastal Zone Management & 1 & 0 & 1 & 1 & 0 & 0 & 1 & 1 & 1 & 0 & & 0 & & & & 0 & 0 & 1 & & 0 & 0 & 0 & 0 & 1 & 10 & 0 & 0 & 0 & 1 & 0 & 0 \\
\hline NOAA & National Coastal Resilience Fund & 1 & 0 & 1 & 1 & 0 & 0 & 1 & 1 & 1 & 1 & & 0 & & c & & 1 & 0 & 1 & 0 & 0 & 0 & 0 & 0 & 1 & 1 & 0 & 0 & 0 & 1 & 0 & 0 \\
\hline & & & & & & & & & & & & & & & & & & & & & & & & & & & & & & & & \\
\hline SBA & Physical Disaster Loans-Business & 1 & 1 & 0 & 0 & 0 & 0 & 0 & 1 & 0 & 0 & 0 & 0 & s & se & & 0 & 1 & 0 & 0 & 0 & 0 & 0 & 1 & 0 & 0 & 0 & 0 & 0 & 0 & 1 & 1 \\
\hline SBA & $\begin{array}{l}\text { Economic Injury Disaster Loans- } \\
\text { Business }\end{array}$ & 1 & 1 & 0 & 0 & 0 & 0 & 0 & 1 & 0 & U & & U & & & & & 1 & & & 0 & & 0 & & & & 0 & 0 & 0 & & 1 & 1 \\
\hline SBA & Home and Personal Property & 1 & 1] & 0 & 0 & 0 & 0 0 & 0 & 1 & 0 & 0 & 0 & 1 & & & & 0 & 0 & 0 & 0 & 1 & 0 & 0 & 1 & & 0 & 0 & 0 & 0 & 0 & 1 & 1 \\
\hline
\end{tabular}




\begin{tabular}{|c|c|c|c|c|c|c|c|c|c|c|c|c|c|c|c|c|c|c|c|c|c|c|c|c|c|c|c|c|c|c|}
\hline & & \multicolumn{6}{|c|}{ Requirements } & \multicolumn{2}{|c|}{ Timing } & \multicolumn{6}{|c|}{ Applicants } & \multicolumn{6}{|c|}{ Focus } & \multicolumn{5}{|c|}{ Hazards } & \multicolumn{4}{|c|}{ Aspects } \\
\hline ency & Program & 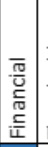 & $\begin{array}{l}\text { no } \\
\frac{0}{0} \\
\frac{5}{y} \\
\frac{2}{c} \\
F\end{array}$ & 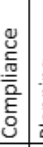 & 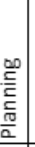 & 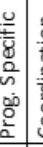 & 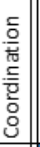 & 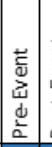 & 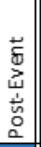 & 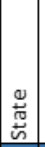 & 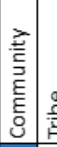 & 窇 & 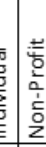 & $\frac{5}{5}$ & 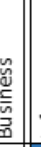 & 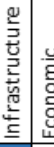 & 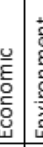 & 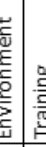 & 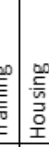 & 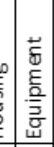 & 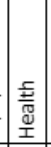 & $\bar{\alpha}$ & 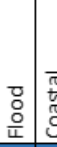 & 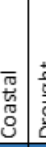 & 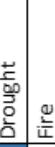 & & 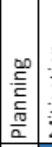 & 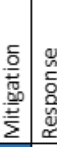 & 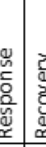 & \\
\hline ISACE & Continuing Authorities & 1 & 0 & 0 & 0 & 0 & 0 & 1 & 1 & 1 & 1 & 0 & 0 & 0 & 0 & 1 & 0 & 0 & 0 . 0 & \begin{tabular}{l|l}
0 & 0 \\
\end{tabular} & 0 & 0 & 1 & 1 & 1 & 0 & 0 & 1 & 0 & 0 \\
\hline ISACE & $\begin{array}{l}\text { Emergency Operations-Flood } \\
\text { Control and Coastal Emergencies }\end{array}$ & 0 & 0 & 0 & 0 & 1 & 0 & 0 & 1 & 1 & 1 & & & & 0 & & & & & & 0 & 0 & & 1 & & 0 & & 0 & & \\
\hline SACE & Flood Managemen & 1 & 0 & 0 & 0 & 0 & 0 & 1 & 1 & 1 & 1 & 1 & 0 & 0 & 0 & 1 & 0 & 0 & 10 & \begin{tabular}{l|l|}
0 & 0 \\
\end{tabular} & 0 & 0 & 1 & 0 & 0 & 0 & 0 & \begin{tabular}{l|l}
1 & \\
\end{tabular} & 0 & 0 \\
\hline & & & & & & & & & & & & & & & & & & & & & & & & & & & & & & \\
\hline USDA & FS Volunteer Fire Assistance & 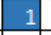 & 0 & 0 & 0 & 0 & 0 & 1 & 0 & 0 & 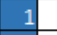 & 0 & c & & 0 & 0 & 0 & 0 & c & 0 & 0 & 0 & 0 & 0 & 0 & 1 & 0 & \begin{tabular}{c|ccc}
1 & 0 & $l$
\end{tabular} & \begin{tabular}{l|l}
0 & \\
0
\end{tabular} & 0 \\
\hline USDA & FS Wildland Fire Management & 0 & 0 & 0 & 0 & 1 & 0 & 1 & 1 & 0 & 1 & 0 & 0 . & 0 & 0 & 1 & 0 & 0 & 1 & $\begin{array}{lll}0 & 0 \\
\end{array}$ & 0 & 0 & 0 & 0 & 0 & 1 & 0 & 1 & 1 & 1 \\
\hline USDA & FSA Emergency & 1 & 1 & 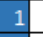 & 0 & 0 & 0 & 0 & 1 & 0 & 0 & 0 & 1 & 0 & 1 & 0 & 0 & 1 & 0 . 0 & \begin{tabular}{l|l|l}
0 & 0 \\
\end{tabular} & 0 & 1 & 0 & 0 & 0 & 0 & 0 & 0 & 1 & 1 \\
\hline USDA & FS & 1 & 1 & 1 & 0 & 0 & 0 & 0 & 1 & 0 & 0 & 0 & 10 & 0 & 1 & 0 & 0 & 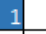 & 0 c & $\begin{array}{lll}0 & 0 \\
\end{array}$ & 0 & 1 & 0 & 0 & 0 & 0 & 0 & 0 & 1 & 1 \\
\hline USDA & $\mathrm{F}$ & 1 & 1 & 1 & 1 & 0 & 0 & 0 & 1 & 0 & 0 & 0 & 10 & 0 & 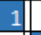 & 0 & 1 & 0 & 0 . 0 & \begin{tabular}{|c|c|c|}
0 & 0 \\
\end{tabular} & 0 & 1 & 0 & 0 & 0 & 0 & 0 & 0 & 1 & 1 \\
\hline USDA & $\begin{array}{l}\text { NRCS Emergency Watershed } \\
\text { Protection-Recovery Assistance }\end{array}$ & 1 & 1 & & 0 & 0 & 0 & 0 & 1 & & 1 & & & & 0 & & & & & & 0 & & 0 & 0 & 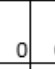 & 0 & & & 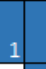 & 1 \\
\hline USDA & $\begin{array}{l}\text { NRCS Environmental Quality } \\
\text { Incentive Program }\end{array}$ & & 0 & & 0 & 0 & 0 & 1 & & & 0 & 1 & & & 0 & 0 & 0 & & 0 & 0 & 0 & & 0 & 0 & 0 & 0 & 0 & & & \\
\hline DA & $\begin{array}{l}\text { NRCS Watershed and Flood } \\
\text { Prevention }\end{array}$ & & 0 & & & 이 & 1 & & 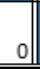 & & 4 & & & & 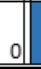 & & 0 & & & & 0 & 0 & & 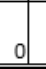 & & 이 & 이 & & & \\
\hline
\end{tabular}




\section{Appendix E. Descriptions of Variables in Program Coding Table}

Table 1. Resilience Program Requirements

Financial Requirements: Applicant must meet some standard of financial or credit capacity in order to qualify.

Threshold Requirements: Applicant must meet one or more externally determined criteria. Compliance Requirements: Applicant must have taken actions to meet specified regulatory standards.

Planning Requirements: Applicant must have approved plans or a planning process in place prior to qualifying for a program

Coordination Requirements: Applicant must demonstrate that resources from other sources have been requested or obtained.

Program-Specific: Requirements that are not shared with other programs in the database or falling into other broad categories. This does not indicate an absence of requirements, just that a program's requirements are unique.

Table 2. Resilience Program Timing

Pre-event: before a disruption

Post-event: after a disruption

Table 3. Resilience Program Applicants

State: State government and State agencies

Community: The people and institutions in a particular area of unspecified size that share risk in the face of a hazard and a network of relationships that allows preparation and response. Communities can be represented by governmental or municipal entities; for the purposes of this study, communities exclude individual States, because States are specifically designated by many Federal programs as recipients of support in the form of block grants to be further disbursed. Communities can, however, be represented by a consortium with one or more State governments participating. Tribes can access community resources, but also have access to additional tribal-specific resources.

Tribe: Federally recognized tribal governments

Individual: A single person representing himself or herself

Non-Profit: A non-governmental organization that receives support from a Federal program to support community facilities, social institutions, or residents. When non-profit organizations receive Federal loans or grants to repair property or replace equipment they own, they are considered businesses for the purposes of this study.

Business: A company or corporation representing itself; not constrained by size. 
Table 4. Resilience Program Focus Areas

Infrastructure: Building, protecting, improving machinery and facilities (for example, buildings, roads, water, sewage, power) that enable the vital functions of a community's governance, public health, and economy; infrastructure can be publicly or privately owned.

Economy: Protection and recovery of fiscal, financial, and commercial activities within a community, including public expenditure, individual income and employment, and business activity

Environment: Management and restoration of natural resources promoting the resilience of a community

Training: Preparing community managers, leaders, and residents to respond to natural disasters or other disruptions of the community

Housing: Residential dwellings occupied by individuals and families

Equipment: Purchase or acquisition of equipment needed to improve a community's resilience in the face of natural disasters or other disruptions

Health: Help the residents of a community prepare for, cope with, and recover from the mental, physical, and other stresses experienced in the aftermath of a natural disaster or other disruption

Table 5. Resilience Program Hazards

\section{Flood}

Coastal: Spans a complex array of closely related hazards such as wind damage, flooding, and loss or movement of emergent land that are also a concern in non-coastal settings. Coastal programs address them as a suite of hazards that share a common cause and amplify each other's effects.

\section{Drought}

Wildfire

All: Unrestricted with respect to hazard type

Table 6. Aspects of Resilience

Planning: Support for carrying out a systematic process to develop executable strategic, operational, and/or community-based approaches to meet resilience objectives in the light of current and expected financial, environmental, and demographic conditions

Mitigation: Support for enhancing capabilities intended to reduce loss of life and property by lessening the impact of disasters, including community-wide risk reduction projects and improvement of the resilience of critical infrastructure and key resource lifelines

Response: Support to save lives, protect property and the environment, and meet basic human needs after an incident has occurred

Recovery: Support for capabilities necessary to assist communities affected by an incident to rebuild or enhance infrastructure systems and housing; restore health, social, and community services; promote economic development; and restore natural and cultural resources 


\section{Appendix F. Community Resilience Tools Database}

\section{Data \& Modeling Tools}

\begin{tabular}{|c|c|c|c|c|c|c|c|c|c|c|c|c|c|}
\hline \multirow[b]{2}{*}{ Tool } & \multirow[b]{2}{*}{ Provider } & \multicolumn{7}{|c|}{ Focus } & \multicolumn{5}{|c|}{ Hazard } \\
\hline & & 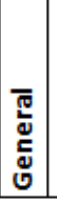 & 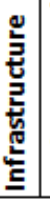 & 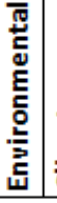 & בัّ & 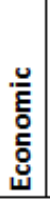 & 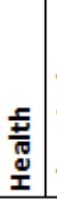 & 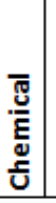 & $\overline{4}$ & \begin{tabular}{|l|} 
焉 \\
怘 \\
\end{tabular} & $\frac{2}{2}$ & 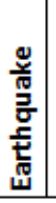 & 른 \\
\hline \multicolumn{14}{|l|}{ Federal Agencies } \\
\hline $\begin{array}{l}\text { Marine Minerals Information } \\
\text { System }\end{array}$ & BOEM & 1 & 0 & 0 & 0 & 0 & 0 & 0 & 0 & 1 & 0 & 0 & 0 \\
\hline $\begin{array}{l}\text { Hazard Mitigation Cost } \\
\text { Effectiveness Tool }\end{array}$ & DOT - FTA & 0 & 0 & 0 & 0 & 1 & 0 & 0 & 1 & 0 & 0 & 0 & 0 \\
\hline Sensitivity Matrix & DOT - FHWA & 0 & 1 & 0 & 0 & 0 & 0 & 0 & 1 & 0 & 0 & 0 & 0 \\
\hline CAMEO Software Suite & EPA, NOAA ORR & 0 & 0 & 0 & 0 & 0 & 0 & 1 & 1 & 0 & 0 & 0 & 0 \\
\hline EnviroAtlas & $\begin{array}{l}\text { EPA, Forest Trends, } \\
\text { Landscope America, } \\
\text { Natureserve, USDA, USGS }\end{array}$ & 0 & 0 & 1 & 0 & 0 & 0 & 0 & 0 & 0 & 0 & & 0 \\
\hline Global Change Explorer & EPA & 0 & 0 & 1 & 0 & 0 & 0 & 0 & 0 & 0 & 0 & 0 & 0 \\
\hline $\begin{array}{l}\text { Data Visualization: Summary of } \\
\text { Disaster Declarations and Grants }\end{array}$ & FEMA & 1 & 0 & 0 & 0 & 0 & 0 & 0 & 1 & 0 & 0 & 0 & 0 \\
\hline Flood Insurace Rate Maps (FIRMs) & FEMA & 0 & 0 & 0 & 0 & 1 & 0 & 0 & 0 & 0 & 1 & 0 & 0 \\
\hline Hazus & FEMA & 1 & 0 & 0 & 0 & 0 & 0 & 0 & 1 & 0 & 0 & 0 & 0 \\
\hline $\begin{array}{l}\text { Resilience Analysis and Planning } \\
\text { Tool (RAPT) }\end{array}$ & FEMA & 1 & 0 & 0 & 0 & 0 & 0 & 0 & 1 & 0 & 0 & 0 & 0 \\
\hline Riverine Flood Innundation Maps & $\begin{array}{l}\text { FEMA, NOAA NWS, NOAA } \\
\text { OCM, USACE, USGS }\end{array}$ & 0 & 0 & 1 & 0 & 0 & 0 & 0 & 0 & 0 & 1 & 0 & 0 \\
\hline $\begin{array}{l}\text { United States Interagency } \\
\text { Elevation Inventory }\end{array}$ & \begin{tabular}{|l|} 
FEMA, National Parks \\
Service, NOAA OCM, USACE, \\
USDA, USGS
\end{tabular} & 1 & 0 & 0 & 0 & 0 & 0 & 0 & & 0 & 0 & & 0 \\
\hline $\begin{array}{l}\text { Economic Decision Guide } \\
\text { Software (EDGe\$) }\end{array}$ & NIST & 0 & 0 & 0 & 0 & 1 & 0 & 0 & & 0 & 0 & 0 & 0 \\
\hline Beach Nourishment Viewer & $\begin{array}{l}\text { Study of Developed } \\
\text { Shoreline }\end{array}$ & 0 & 0 & 1 & 0 & 0 & 0 & 0 & & 1 & 0 & 0 & 0 \\
\hline C-CAP Land Cover Analysis & NOAA OCM & 0 & 0 & 1 & 0 & 0 & 0 & 0 & & 1 & 0 & 0 & 0 \\
\hline CoastalCounty Snapshots & NOAA OCM & 1 & 0 & 0 & 0 & 0 & 0 & 0 & & 1 & 0 & 0 & 0 \\
\hline CoastalFlood Exposure Mapper & NOAA OCM & 1 & 0 & 0 & 0 & 0 & 0 & 0 & & 1 & 0 & 0 & 0 \\
\hline Digital Coast Partnership & $\begin{array}{l}\text { NOAA Office for } \\
\text { CoastalManagement }\end{array}$ & 1 & 0 & 0 & 0 & 0 & 0 & 0 & & 1 & 0 & 0 & 0 \\
\hline $\begin{array}{l}\text { Environmental Response } \\
\text { Management Application }\end{array}$ & NOAA ORR & & 0 & & 0 & & 0 & 이 & & & & & \\
\hline
\end{tabular}




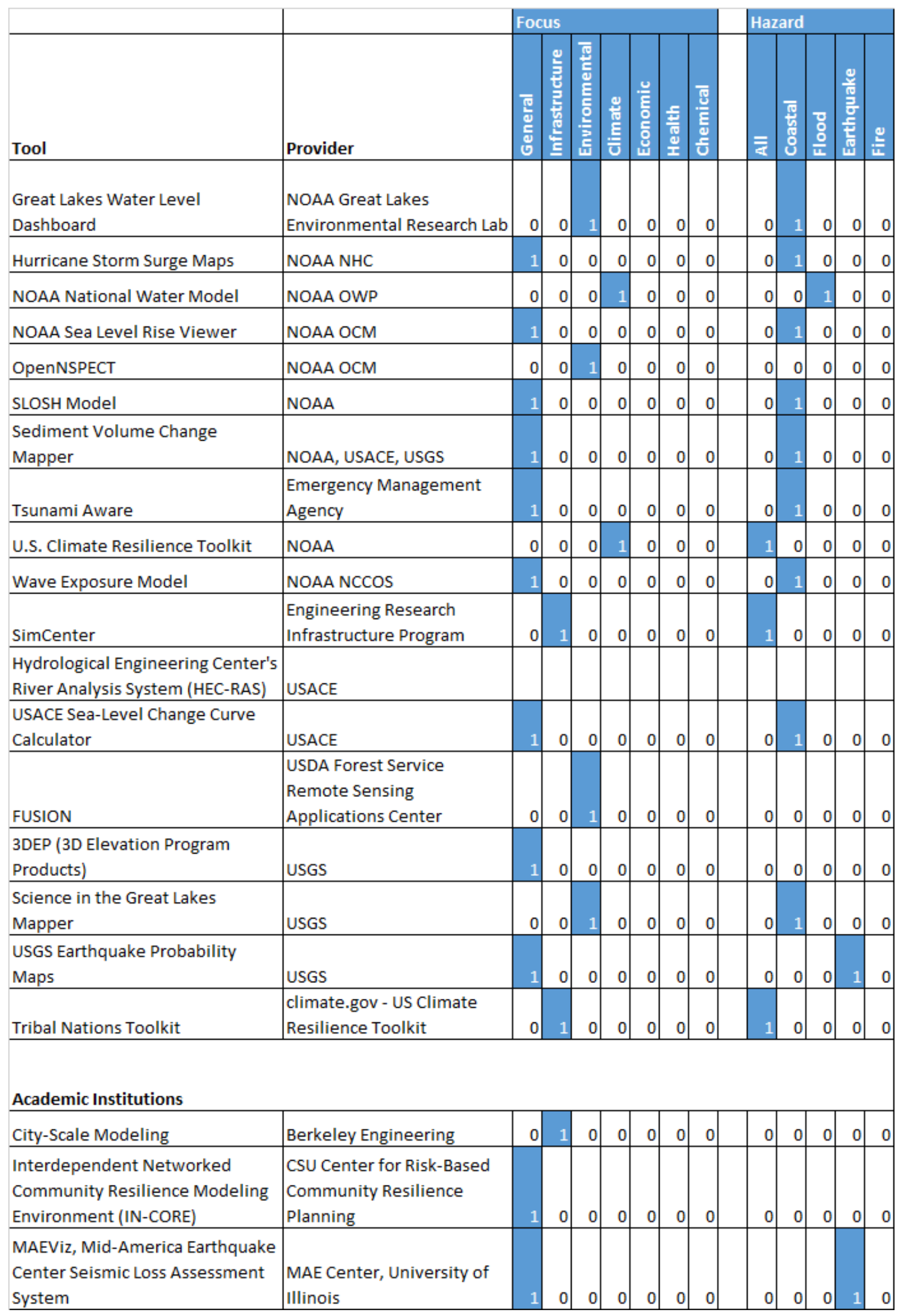




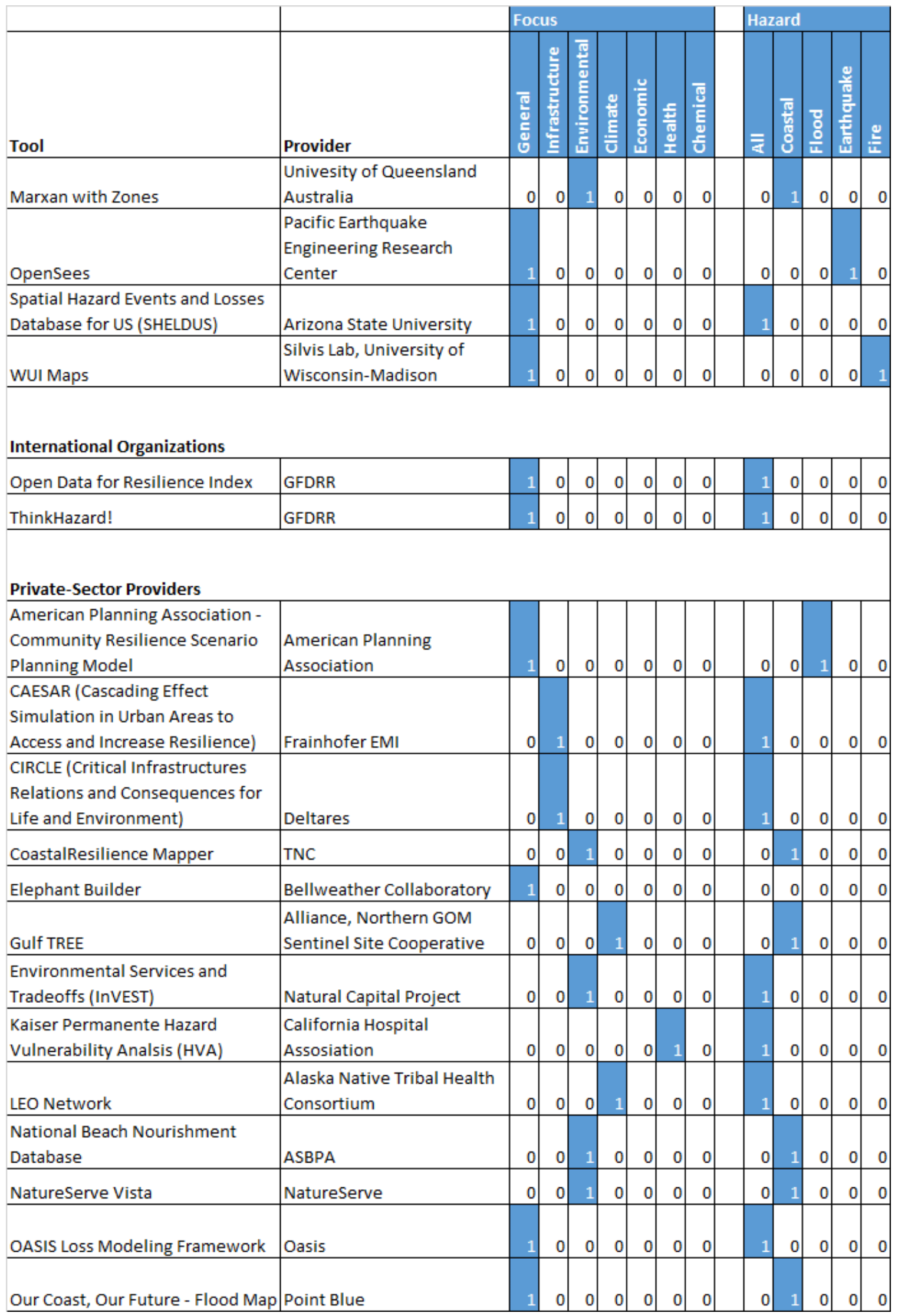




\begin{tabular}{|c|c|c|c|c|c|c|c|c|c|c|c|c|c|}
\hline \multirow[b]{2}{*}{ Tool } & \multirow[b]{2}{*}{ Provider } & \multicolumn{7}{|c|}{ Focus } & \multicolumn{5}{|c|}{ Hazard } \\
\hline & & 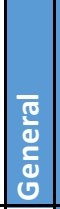 & 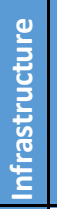 & 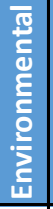 & 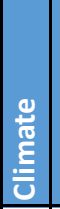 & 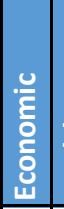 & 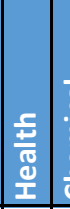 & 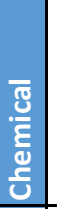 & $\bar{\alpha}$ & $\mid$\begin{tabular}{|}
$\overline{5}$ \\
$\frac{5}{5}$ \\
0 \\
0 \\
0 \\
\end{tabular} & \begin{tabular}{|l|}
$:$ \\
$\frac{8}{2}$ \\
\end{tabular} & 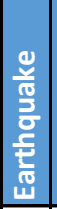 & 은 \\
\hline OurWater & The Resilience Shift & 0 & 1 & 0 & 0 & 0 & 0 & 0 & 0 & 0 & 0 & 0 & 0 \\
\hline $\begin{array}{l}\text { Partnership for Resilience and } \\
\text { Preparedness Data }\end{array}$ & World Research Institute & 0 & 0 & 0 & 1 & 0 & 0 & 0 & 1 & 0 & 0 & & 0 \\
\hline Resilience Atlas & Conservation International & 1 & 0 & 0 & 0 & 0 & 0 & 0 & 0 & 0 & 0 & 0 & 0 \\
\hline Resilience.io & \begin{tabular}{|l} 
Ecological Sequestration \\
Trust
\end{tabular} & \pm & 0 & 0 & 0 & 0 & 0 & 0 & 0 & 0 & 0 & 0 & 0 \\
\hline Surging Seas & Climate Central & 0 & 0 & 0 & 1 & 0 & 0 & 0 & 0 & 1 & 0 & 0 & 0 \\
\hline $\begin{array}{l}\text { The Standard for Sustainable and } \\
\text { Resilience Infrastructure (SuRe) } \\
\end{array}$ & Global Infrastructure Basel & 0 & 1 & 0 & 0 & 0 & 0 & 0 & 1 & 0 & 0 & 0 & 0 \\
\hline XDIGlobe & $\begin{array}{l}\text { XDI Cross Dependency } \\
\text { Initiative }\end{array}$ & 0 & 0 & 0 & & 0 & 0 & 0 & & & & & 0 \\
\hline
\end{tabular}

\section{Assessment Tools}

\begin{tabular}{|c|c|c|c|c|c|c|c|c|c|c|}
\hline \multirow[b]{2}{*}{ Tool } & \multirow[b]{2}{*}{ Provider } & \multicolumn{5}{|c|}{ Focus } & \multicolumn{4}{|c|}{ Hazard } \\
\hline & & 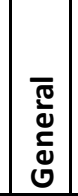 & 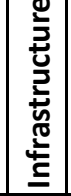 & 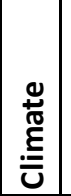 & 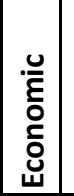 & 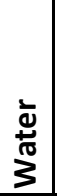 & $\overline{\bar{\alpha}}$ & 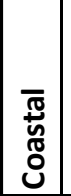 & $\frac{8}{8}$ & $\stackrel{一}{\underline{2}}$ \\
\hline \multicolumn{11}{|l|}{ Federal Agencies } \\
\hline Infrastructure Survey Tool (IST) & DHS & 0 & 1 & 0 & 0 & 0 & 1 & 0 & 0 & 0 \\
\hline $\begin{array}{l}\text { Transportation Adaptation } \\
\text { Planning }\end{array}$ & DOT - FHWA & 0 & 1 & 0 & 0 & 0 & 1 & 0 & 0 & 0 \\
\hline $\begin{array}{l}\text { Vulnerability Assessment Scoring } \\
\text { Tool }\end{array}$ & DOT - FHWA & 0 & 1 & 0 & 0 & 0 & 1 & 0 & 0 & 0 \\
\hline $\begin{array}{l}\text { EPA Flood Resilience Checklist } \\
\text { [EPA 2014] }\end{array}$ & EPA & 1 & 0 & 0 & 0 & 0 & 0 & 0 & 1 & 0 \\
\hline $\begin{array}{l}\text { NFIP Community Rating System } \\
\text { Coordinator's Manual }\end{array}$ & FEMA & 1 & 0 & 0 & 0 & 0 & 0 & 0 & 1 & 0 \\
\hline National Risk Index & FEMA & 1 & 0 & 0 & 0 & 0 & 1 & 0 & 0 & 0 \\
\hline Preparedness Toolkit & FEMA & 1 & 0 & 0 & 0 & 0 & 1 & 0 & 0 & 0 \\
\hline and Risk Assessment (THIRA) & FEMA & 1 & 0 & 0 & 0 & 0 & 1 & 0 & 0 & 0 \\
\hline $\begin{array}{l}\text { Wildland Urban Interface (WUI) } \\
\text { Toolkit }\end{array}$ & FEMA & 1 & 0 & 0 & 0 & 0 & 0 & 0 & 0 & 1 \\
\hline $\begin{array}{l}\text { Decision Guide for Buildings and } \\
\text { Infrastructure Systems }\end{array}$ & NIST & 0 & 0 & 0 & 1 & 0 & $\perp$ & 0 & 0 & 0 \\
\hline
\end{tabular}




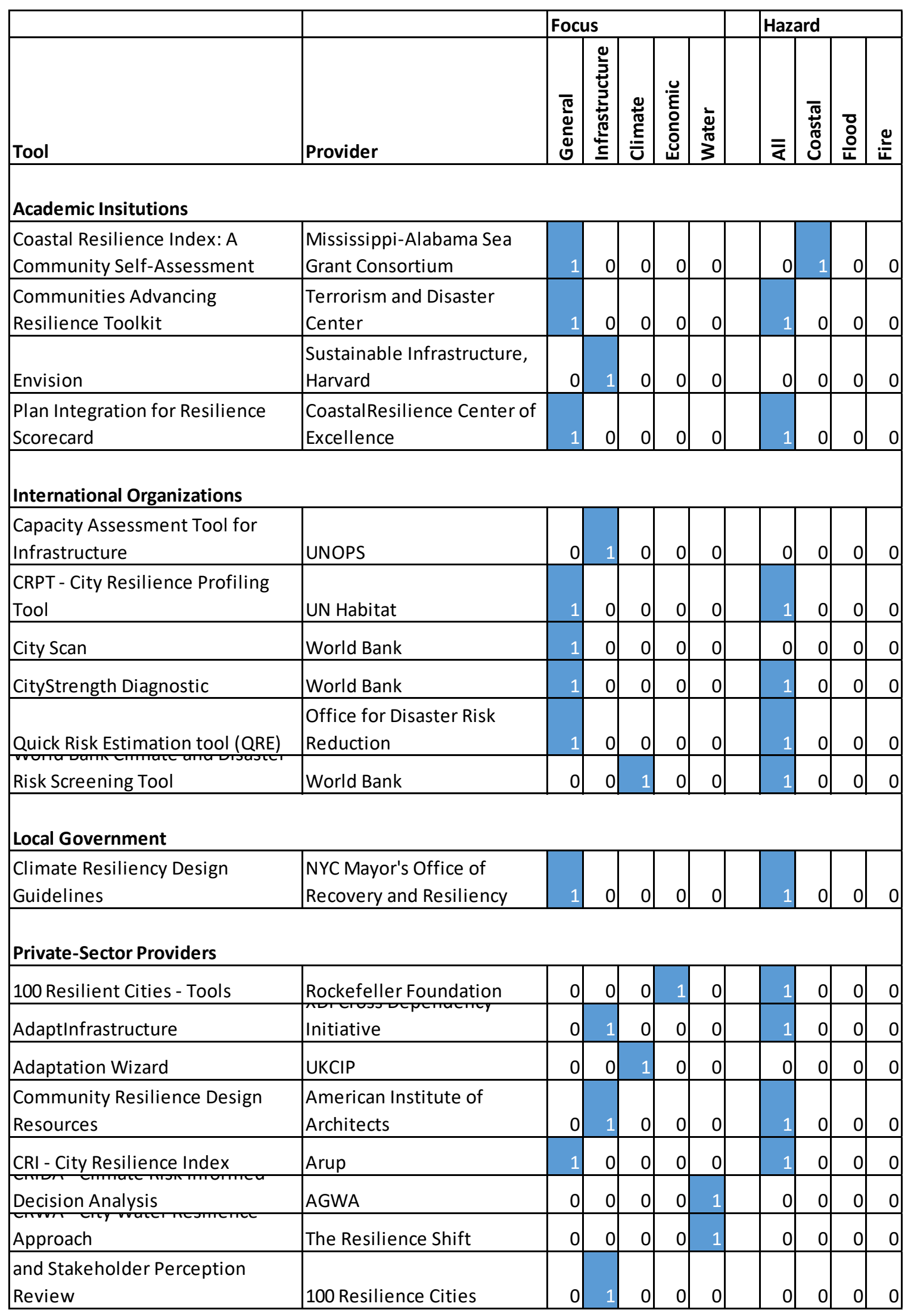




\begin{tabular}{|c|c|c|c|c|c|c|c|c|c|c|}
\hline \multirow[b]{2}{*}{ Tool } & \multirow[b]{2}{*}{ Provider } & \multicolumn{5}{|c|}{ Focus } & \multicolumn{4}{|c|}{ Hazard } \\
\hline & & $\mid$\begin{tabular}{l|}
$\bar{\pi}$ \\
$\bar{\Xi}$ \\
$\bar{\Xi}$ \\
$\mathbb{J}$ \\
\end{tabular} & 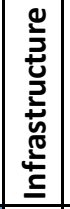 & 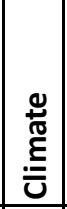 & 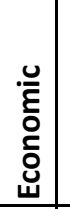 & 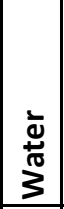 & $\overline{\bar{\alpha}}$ & 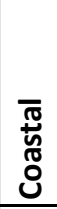 & $\begin{array}{l} \\
\\
\end{array}$ & $\stackrel{0}{2}$ \\
\hline $\begin{array}{l}\text { Assessment Framework and Tools } \\
\text { (CRAFT) }\end{array}$ & IBTS & 1 & 0 & 0 & 0 & 0 & 1 & 0 & 0 & 0 \\
\hline GRESB Resilience Module & GRESB & 0 & 0 & 0 & 1 & 0 & 0 & 0 & 0 & 0 \\
\hline ICLEI ACCCRN Process Workbook & $\begin{array}{l}\text { ICLEl and Rockefeller } \\
\text { Foundation }\end{array}$ & 0 & 0 & 1 & 0 & 0 & 0 & 0 & 0 & 0 \\
\hline $\begin{array}{l}\text { Participatory Capacity and } \\
\text { Vulnerability Analysis (PCVA) }\end{array}$ & Oxfam & 1 & 0 & 0 & 0 & 0 & 1 & 0 & 0 & 0 \\
\hline $\begin{array}{l}\text { The Resilience Action List (RELi) } \\
\text { Standard }\end{array}$ & $\mathrm{GBCl}$ & 0 & 1 & 0 & 0 & 0 & 1 & 0 & 0 & 0 \\
\hline
\end{tabular}

\section{Guides}

\begin{tabular}{|c|c|c|c|c|c|c|c|c|}
\hline & & \multicolumn{5}{|c|}{ Focus } & \multicolumn{2}{|c|}{ Hazard } \\
\hline Tool & Provider & $\begin{array}{l}\overline{\mathrm{c}} \\
\mathrm{d} \\
\mathrm{d}\end{array}$ & 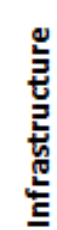 & 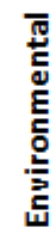 & & 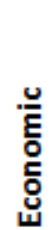 & $\overline{4}$ & 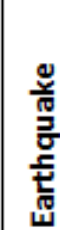 \\
\hline
\end{tabular}

Federal Agencies

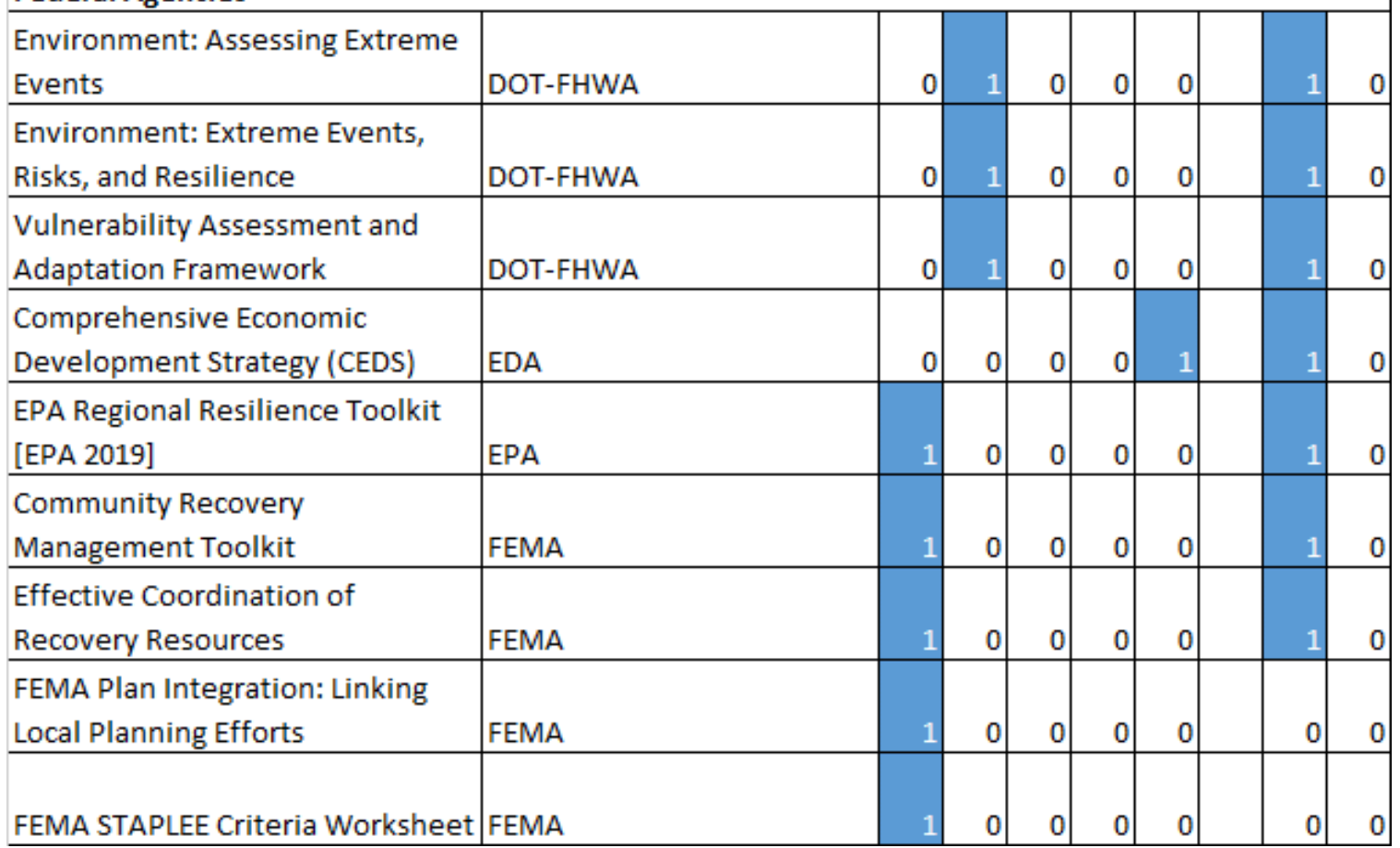




\begin{tabular}{|c|c|c|c|c|c|c|c|c|}
\hline \multirow[b]{2}{*}{ Tool } & \multirow[b]{2}{*}{ Provider } & \multicolumn{5}{|c|}{ Focus } & \multicolumn{2}{|c|}{ Hazard } \\
\hline & & 인 & 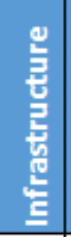 & 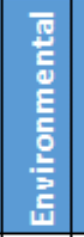 & 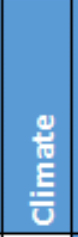 & 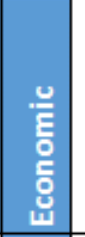 & द & 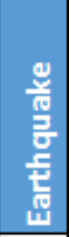 \\
\hline $\begin{array}{l}\text { Listing of Disaster Recovery } \\
\text { Funding Resources }\end{array}$ & FEMA & 0 & 0 & 0 & 0 & 1 & 1 & 0 \\
\hline $\begin{array}{l}\text { Planning Process: A Self-Help } \\
\text { Guide }\end{array}$ & FEMA & 1 & 0 & 0 & 0 & 0 & 1 & 0 \\
\hline $\begin{array}{l}\text { Potential Loss of FEMA Public } \\
\text { Assistance Funding }\end{array}$ & FEMA & 1 & 0 & 0 & 0 & 0 & 0 & 0 \\
\hline $\begin{array}{l}\text { National Disaster Recovery } \\
\text { Framework (NDRF) }\end{array}$ & FEMA & 1 & 0 & 0 & 0 & 0 & 1 & 0 \\
\hline $\begin{array}{l}\text { Pre-Disaster Recovery Guide for } \\
\text { Local Governments }\end{array}$ & FEMA & 1 & 0 & 0 & 0 & 0 & 1 & 0 \\
\hline $\begin{array}{l}\text { Pre-Disaster Recovery Planning } \\
\text { Guide for State Governments }\end{array}$ & FEMA & 1 & 0 & 0 & 0 & 0 & 1 & 0 \\
\hline $\begin{array}{l}\text { HUD Community Resilience } \\
\text { Planning Resources }\end{array}$ & HUD & 1 & 0 & 0 & 0 & 0 & 1 & 0 \\
\hline $\begin{array}{l}\text { Guide for Buildings and } \\
\text { Infrastructure Systems }\end{array}$ & NIST & 1 & 0 & 0 & 0 & 0 & 1 & 0 \\
\hline $\begin{array}{l}\text { Community Facilities } \\
\text { Infrastructure Toolkit }\end{array}$ & USDA & 1 & 0 & 0 & 0 & 0 & 1 & 0 \\
\hline Academic Institutions & & & & & & & & \\
\hline $\begin{array}{l}\text { Crosswalking Between Gray and } \\
\text { Green Infrastructure for Budget } \\
\text { Officers }\end{array}$ & $\begin{array}{l}\text { UNC Environmental Finance } \\
\text { Center }\end{array}$ & 0 & 0 & 1 & 0 & 0 & 0 & 0 \\
\hline Private-Sector Providers & & & & & & & & \\
\hline $\begin{array}{l}\text { Adaptation Framework and } \\
\text { Taxonomy }\end{array}$ & Arup & 0 & 0 & 0 & 1 & 0 & 0 & 0 \\
\hline Community Resilience Building & The Nature Conservancy & 1 & 0 & 0 & 0 & 0 & 1 & 0 \\
\hline $\begin{array}{l}\text { Ecoadapt Climate Adaptation } \\
\text { Knowledge Exchange }\end{array}$ & Ecoadapt & 0 & 0 & 0 & 1 & 0 & 1 & 0 \\
\hline HAZUR & OPTICITS & 1 & 0 & 0 & 0 & 0 & 0 & 0 \\
\hline $\begin{array}{l}\text { RAND Community Resilience } \\
\text { Toolkits }\end{array}$ & RAND & 1 & 0 & 0 & 0 & 0 & 0 & 0 \\
\hline $\begin{array}{l}\text { Resilience Value Realization } \\
\text { (RVR) }\end{array}$ & Marcela Ruibal & 1 & 0 & 0 & 0 & 0 & 0 & 0 \\
\hline $\begin{array}{l}\text { Resilience-based Earthquake } \\
\text { Design Initiative (REDi) }\end{array}$ & Arup & 0 & 1 & 0 & 0 & 0 & 0 & 1 \\
\hline
\end{tabular}




\section{Appendix G. Descriptions of Variables in Resilience Tools Database}

Table 1. Types of Tools

Guides: Any resource that presents a general methodology or framework for addressing aspects of resilience, including how to develop plans, projects, and strategies.

Assessments: Any tool that uses information specific to a community to evaluate any component(s) of its resilience. Assessments include checklists and scorecards; they can be documents or interactive digital tools.

Data \& Modeling: Any tool that provides access to data necessary for modeling and assessment or that simulates a hazard scenario. Data and models may be integrated. These tools include both online web interfaces and downloadable data files and software.

Table 2. Types of Tool Providers

Federal Agency: Provider is a Federal agency or office. These tools are freely available.

Private Sector: Provider is a private-sector entity; can be for-profit or non-profit. Tools provided by non-profit entities are generally free, but some provided by for-profit entities may require purchase.

Local Government: Provider is a public agency or office serving a specific community or region.

Academic Institution: Provider is based at an academic institution.

International Organization: Provider is an international entity, possibly with support from more than one government.

\section{Table 3. Types of Hazards}

\section{Flood}

Coastal: Spans a complex array of closely related hazards such as wind damage, flooding, and loss or movement of emergent land that are also a concern in non-coastal settings. Coastal programs address them as a suite of hazards that share a common cause and amplify each other's effects.

\section{Drought}

Earthquake

Wildfire

All: Unrestricted with respect to hazard type 
Table 4. Primary Focus of Tools

General: Focus on resilience as a property of a community or system emerging from the intersection of disparate factors and concerns that a community must integrate to foster resilience, including hazards, infrastructure, social institutions, governance, economic wellbeing, land use, etc. In addition, in the case of data and modeling tools, the general focus area also includes those tools that provide fundamental information that applies more broadly than resilience analysis.

Infrastructure: Focus on building, protecting or improving machinery and facilities (for example, buildings, roads, water, sewage, power) that enable the vital functions of a community's governance, public health, and economy.

Environmental: Management and restoration of natural resources contributing to the resilience of a community.

Climate: Focus is to help users evaluate how their circumstances will change due to climate impacts on social, economic, environmental, and physical systems. Climate impacts need not be related to natural disasters or particular hazards.

Economic: Fiscal, financial, and commercial activities within a community, including public expenditure, individual income and employment, and business activity.

Water Quality: Water sources, treatment, distribution, collection, and quality.

Health: Help the residents of a community prepare for, cope with, and recover from the mental, physical, and other stresses experienced in the aftermath of a natural disaster or other disruption.

Chemical: Hazardous chemicals.

Table 4. Resilience Program Focus Areas

Infrastructure: Building, protecting, improving machinery and facilities (for example, buildings, roads, water, sewage, power) that enable the vital functions of a community's governance, public health, and economy; infrastructure can be publicly or privately owned.

Economy: Protection and recovery of fiscal, financial, and commercial activities within a community, including public expenditure, individual income and employment, and business activity

Environment: Management and restoration of natural resources promoting the resilience of a community

Training: Preparing community managers, leaders, and residents to respond to natural disasters or other disruptions of the community

Housing: Residential dwellings occupied by individuals and families

Equipment: Purchase or acquisition of equipment needed to improve a community's resilience in the face of natural disasters or other disruptions

Health: Help the residents of a community prepare for, cope with, and recover from the mental, physical, and other stresses experienced in the aftermath of a natural disaster or other disruption 
Table 5. Resilience Program Hazards

Flood

Coastal: Spans a complex array of closely related hazards such as wind damage, flooding, and loss or movement of emergent land that are also a concern in non-coastal settings. Coastal programs address them as a suite of hazards that share a common cause and amplify each other's effects.

Drought

Wildfire

All: Unrestricted with respect to hazard type

Table 6. Aspects of Resilience

Planning: Support for carrying out a systematic process to develop executable strategic, operational, and/or community-based approaches to meet resilience objectives in the light of current and expected financial, environmental, and demographic conditions

Mitigation: Support for enhancing capabilities intended to reduce loss of life and property by lessening the impact of disasters, including community-wide risk reduction projects and improvement of the resilience of critical infrastructure and key resource lifelines

Response: Support to save lives, protect property and the environment, and meet basic human needs after an incident has occurred

Recovery: Support for capabilities necessary to assist communities affected by an incident to rebuild or enhance infrastructure systems and housing; restore health, social, and community services; promote economic development; and restore natural and cultural resources 


\section{References}

Currie, Christopher. 2019. Disaster Resilience Framework: Principles for Analyzing Federal Efforts to Facilitate and Promote Resilience to Natural Disasters. GAO-20100SP. Washington, DC: Government Accountability Office.

Currie, Christopher. 2015. Hurricane Sandy: An Investment Strategy Could Help the Federal Government Enhance National Resilience for Future Disasters. GAO-15515. Washington, DC: Government Accountability Office.

Humphreys, Brian E. 2019. Critical Infrastructure: Emerging Trends and Policy Considerations for Congress. CRS Report No. R45809. Washington, DC: Congressional Research Service.

McAllister, Therese, Clavin, Christopher, Ellingwood, Bruce, van de Lindt, John, Mizzen, David, and Lavelle, Francis. 2019. Data, Information, and Tools Needed for Community Resilience Planning and Decision-Making. NIST Special Publication 1240. Washington, DC: National Institute of Standards and Technology.

Moteff, John D. 2012. Critical Infrastructure Resilience: The Evolution of Policy and Programs and Issues for Congress. CRS Report No. 7-5700. Washington, DC: Congressional Research Service.

National Institute of Standards and Technology. 2016. Community Resilience Planning Guide for Buildings and Infrastructure Systems, Volume I. NIST Special Publication 1190. Washington, DC: National Institute of Standards and Technology.

National Institute of Standards and Technology. 2019. "NIST Community Resilience". 2019. https://www.nist.gov/topics/community-resilience.

National Preparedness Goal. 2015. National Preparedness Goal, $2^{\text {nd }}$ ed. Washington, DC: Department of Homeland Security.

National Research Council. 2012. Disaster Resilience: A National Imperative. Washington, DC: The National Academies Press.

National Academies of Sciences, Engineering, and Medicine 2018. The State of Resilience: A Leadership Forum and Community Workshop: Proceedings of a Workshop. Washington, DC: The National Academies Press.

National Academies of Sciences, Engineering, and Medicine 2019. Building and Measuring Community Resilience: Actions for Communities and the Gulf Research Program. Washington, DC: The National Academies Press.

NIPP. 2013. National Infrastructure Protection Plan: Partnering for Critical Infrastructure Security and Resilience. Washington, DC: Department of Homeland Security.

Patel, S.S., Rogers, M.B., Amlôt, R., and Rubin, G.J. 2017. "What Do We Mean by 'Community Resilience'? A Systematic Literature Review of How it is Defined in the Literature." PLOS Currents Disasters 1, February. doi: 10.1371/currents.dis.db775aff25efc5ac4f0660ad9c9f7db2. 


\section{Abbreviations}

BIA

CCP

CDBG

DCM

DHS

DLS

DOC

DOL

DOT

DUA

EDA

EHP

EPA

FEMA

FHWA

FS

FSA

FTA

HUD

IHP

$\mathrm{MC} / \mathrm{EA}$

MitFLG

MOU

NIST

NOAA

NRCS

PPD-21

PPD-8

SBA

USACE

USDA
Bureau of Indian Affairs

Crisis Counseling Assistance and Training Program

Community Development Block Program

Disaster Care Management

Department of Homeland Security

Disaster Legal Services

Department of Commerce

Department of Labor

Department of Transportation

Disaster Unemployment Assistance through the DOL

Economic Development Administration

Environmental Planning and Historic Preservation

Environmental Protection Agency

Federal Emergency Management Agency

Federal Highway Administration

U.S. Forest Service

Farm Service Agency

Federal Transit Administration

U.S. Department of Housing and Urban Development

Individuals and Households Program

Mass Care and Emergency Assistance

Mitigation Framework Leadership Group

Memorandum of Understanding

National Institute of Standards and Technology

National Oceanic and Atmospheric Administration

Natural Resources Conservation Service

Presidential Policy Directive 21

Presidential Policy Directive 8

Small Business Administration

U.S. Army Corps of Engineers

U.S. Department of Agriculture 